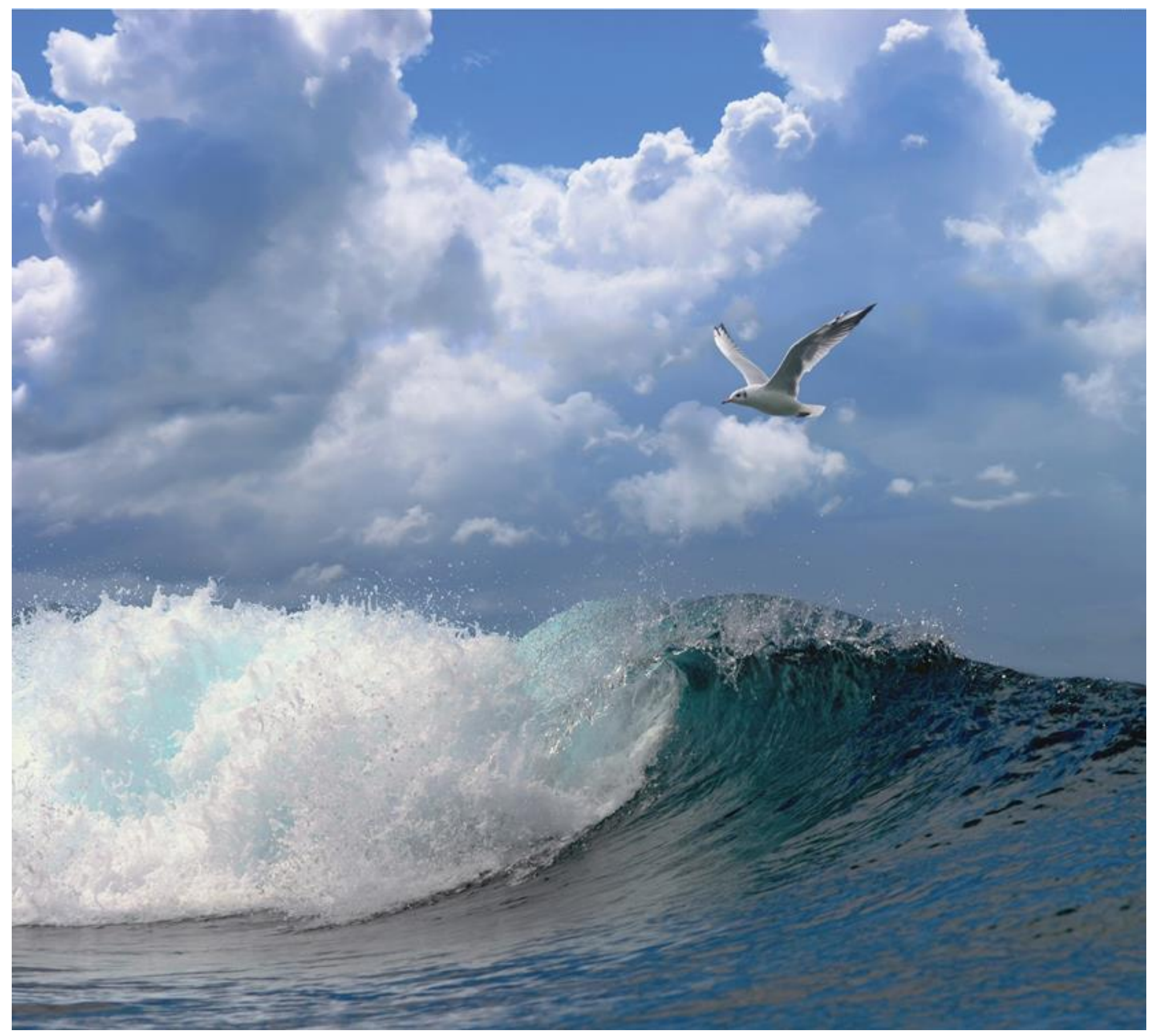

\title{
Potenties voor herstel getijdenatuur in het Haringvliet, Hollands Diep en de Biesbosch
}




\section{Potenties voor herstel getijdenatuur in het Haringvliet, Hollands Diep en de Biesbosch}

Auteur(s): $\quad$ Jeroen Wijsman ${ }^{1}$, Vincent Escaravage ${ }^{1}$, Ymkje Huismans $^{2}$, Arno Nolte ${ }^{2}$, Remi van der Wijk ${ }^{2}$, Zheng Bing Wang ${ }^{2}$ en Tom Ysebaert ${ }^{1}$

Publicatiedatum: 31 januari 2018 
Jeroen Wijsman1, Vincent Escaravage ${ }^{1}$, Ymkje Huismans², Arno Nolte², Remi van der Wijk², Zheng Bing Wang 2 en Tom Ysebaert, Potenties voor herstel getijdenatuur in het Haringvliet, Hollands Diep en de Biesbosch. Wageningen Marine Research Wageningen UR (University \& Research centre), Wageningen Marine Research rapport C008/18. $110 \mathrm{blz}$.

Keywords: Haringvlietsluizen, Ecotopen, modellering, Kierbesluit, Zeespiegelstijging

Opdrachtgever: WNF

T.a.v.: Bas Roels

Postbus 7

3700 AA Zeist

Dit rapport is gratis te downloaden van https://doi.org/10.18174/440424

Wageningen Marine Research verstrekt geen gedrukte exemplaren van rapporten.

Wageningen Marine Research Wageningen UR is ISO 9001:2008 gecertificeerd.

(c) 2018 Wageningen Marine Research Wageningen UR

Wageningen Marine Research, onderdeel van Stichting Wageningen Research KvK nr. 09098104,

IMARES BTW nr. NL 8113.83.696.B16. Code BIC/SWIFT address: RABONL2U IBAN code: NL 73 RABO 0373599285
De Directie van Wageningen Marine Research is niet aansprakelijk voor gevolgschade, noch voor schade welke voortvloeit uit toepassingen van de resultaten van werkzaamheden of andere gegevens verkregen van Wageningen Marine Research opdrachtgever vrijwaart Wageningen Marine Research van aanspraken van derden in verband met deze toepassing.

Dit rapport is vervaardigd op verzoek van de opdrachtgever hierboven aangegeven en is zijn eigendom. Niets uit dit rapport mag weergegeven en/of gepubliceerd worden, gefotokopieerd of op enige andere manier gebruikt worden zonder schriftelijke toestemming van de opdrachtgever. 


\section{Inhoud}

$1 \quad$ Inleiding

1.1 Achtergrond $\quad 8$

1.2 Doelstelling van deze studie $\quad 8$

$\begin{array}{lll}1.3 & \text { Onderzoeksvragen } & 9\end{array}$

1.4 Methodiek $r$

1.5 Afbakening 11

$\begin{array}{ll}1.6 & \text { Leeswijzer } \\ 1.7 & 11\end{array}$

1.7 Dankwoord 11

2 Onderzoeksgebied $\quad 12$

3 Varianten $\quad 14$

3.1 Huidig beheer $\quad 14$

3.2 Kierbesluit $\quad 15$

$\begin{array}{ll}3.380 \mathrm{~cm} \text { getij } & 15\end{array}$

$\begin{array}{ll}3.4 & \text { Stormvloedkering } \\ 3.5 & \text { Klimatscenario }\end{array}$

$\begin{array}{lll}3.5 & \text { Klimaatscenario } & 16\end{array}$

$4 \quad$ Hydrodynamica en zoutgehalte $\quad 17$

$\begin{array}{lll}4.1 & \text { Model en schematisatie } & 17\end{array}$

$\begin{array}{llr}4.2 & \text { Randvoorwaarden } & 18\end{array}$

4.3 Resultaten $\quad 18$

$\begin{array}{lll}\text { 4.3.1 Vergelijking varianten } & 19\end{array}$

4.3.2 Huidig beheer: vergelijking berekende resultaten met metingen 20

$\begin{array}{lll}4.3 .3 & \text { Variant } 80 \mathrm{~cm} \text { getij } & 22\end{array}$

4.3.4 Variant Stormvloedkering $\quad 23$

4.3.5 Variant Klimaatscenario $\quad 23$

$\begin{array}{lll}4.4 & \text { Conclusies hydrodynamische modellering } & 23\end{array}$

4.5 Inschatting zoutindringing bij ander beheer Haringvlietsluizen $\quad 24$

$\begin{array}{lll}\text { 4.5.1 Achtergrond } & 24\end{array}$

4.5.2 Zoutindringing bij de variant Kierbesluit 25

4.5.3 Zoutindringing bij de variant Stormvloedkering $\quad 25$

4.5.4 Zoutindringing bij variant $80 \mathrm{~cm}$ getij 26

$\begin{array}{lll}4.5 .5 & \text { Zoutindringing bij de variant Klimaatverandering } & 27\end{array}$

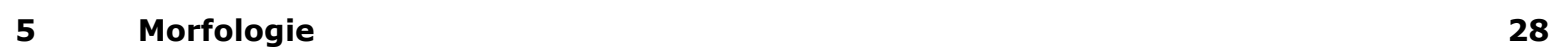

$\begin{array}{lll}5.1 & \text { Inleiding } & 28\end{array}$

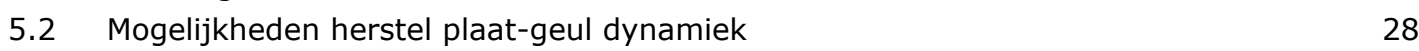

5.2.1 Zandhonger, plaat-geul dynamiek en oevererosie $\quad 28$

$\begin{array}{lll}5.2 .2 & \text { Haringvliet voor en na sluiting } & 30\end{array}$

5.2.3 Dynamiek bij alternatief stuurprogramma $\quad 32$

$\begin{array}{lll}5.2 .4 & \text { Vervuild slib } & 41\end{array}$

5.2.5 Bodembescherming Haringvlietsluizen 42

5.2.6 Morfologische ontwikkelingen in de Rijn-Maasmonding 42

$\begin{array}{lll}\text { 5.2.7 } & \text { Flankerende maatregelen } & 43\end{array}$

5.3 Buitendelta van het Haringvliet 44 
6.1 Indeling ecotopen $\quad 49$

6.1.1 Hoogteligging $\quad 49$

6.1.2 Zoutgehalte $\quad 50$

6.1.3 Ecotopen $\quad 54$

6.2 Berekening ecotopen $\quad 54$

6.2.1 Bathymetrie $\quad 54$

6.2.2 Waterstanden en statistieken $\quad 54$

$\begin{array}{lll}6.3 & \text { Ecotopenkaarten en arealen } & 56\end{array}$

6.3.1 Ecotopenkaarten $\quad 56$

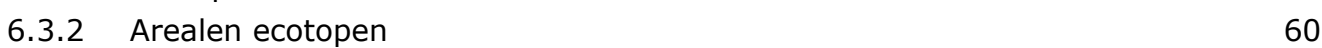

6.4 Potentiële natuurwaarden ecotopen $\quad 62$

6.4.1 Brakwater ecotopen $\quad 62$

$\begin{array}{lll}6.4 .2 & \text { Intergetijdengebieden } & 63\end{array}$

$\begin{array}{llr}7 & \text { Conclusies en discussie } & 66\end{array}$

$\begin{array}{lll}7.1 & \text { Conclusies onderzoeksvragen } & 66\end{array}$

$\begin{array}{lll}7.2 & \text { Discussie } & 68\end{array}$

$8 \quad$ Kwaliteitsborging $\quad 75$

$\begin{array}{lr}\text { Literatuur } & 76\end{array}$

$\begin{array}{lr}\text { Verantwoording } & 79\end{array}$

Bijlage 1 Modelresultaten getijparameters Huidig beheer $\quad 80$

$\begin{array}{lll}\text { Bijlage } 2 & \text { Modelresultaten getijparameters } 80 \mathrm{~cm} \text { getij } & 86\end{array}$

$\begin{array}{llll}\text { Bijlage } 3 & \text { Modelresultaten getijparameters Stormvloedkering } & \mathbf{8 8}\end{array}$

$\begin{array}{lll}\text { Bijlage } 4 & \text { Modelresultaten getijparameters Klimaatscenario } & 90\end{array}$

Bijlage $5 \quad$ Indeling op basis van hoogteligging $\quad 92$

$\begin{array}{llr}\text { Bijlage } 6 & \text { Waterstanden } & 93\end{array}$

$\begin{array}{llr}\text { Bijlage } 7 & \text { Ecotopenkaarten Haringvliet west } & 98\end{array}$

$\begin{array}{llr}\text { Bijlage } 8 & \text { Ecotopenkaarten Tiengemeten } & 99\end{array}$

$\begin{array}{llr}\text { Bijlage } 9 & 100\end{array}$

$\begin{array}{llr}\text { Bijlage } 10 & \text { Arealen ecotopen deelgebieden } & 101\end{array}$

$\begin{array}{llr}\text { Bijlage } 11 & \text { Verschilkaarten Ecotopen } & 106\end{array}$ 


\section{Samenvatting}

In verband met de verwachte positieve effecten op de natuur, met name het herstel van vismigratie, gaan vanaf 2018 de Haringvlietsluizen op een kier. Als gevolg van deze aanpassing kan er tijdens vloed zoutwater binnendringen in het westelijk deel van het Haringvliet. Het verder openzetten van de Haringvlietsluizen dan alleen op een kier, biedt ook de mogelijkheid voor meer getijdynamiek in het Haringvliet, maar ook verder landinwaarts, het Hollands Diep en de Biesbosch, waardoor er meer intergetijdengebied ontstaat. In deze studie is een verkenning gedaan naar de mogelijkheden van het herstel van getijdenatuur in het Haringvliet, Hollands Diep en de Biesbosch.

In deze studie zijn vijf varianten doorgerekend: (1) Huidig beheer, (2) Kierbesluit, (3) $80 \mathrm{~cm}$ getij, (4) Stormvloedkering en (5) Klimaatscenario (met stormvloedkering). Voor de variant Kierbesluit is aangenomen dat dit alleen effect heeft op de zoutindringing en dat de waterstandfluctuaties identiek zijn t.o.v. Huidig beheer. Bij de varianten Stormvloedkering en Klimaatscenario staan de Haringvlietsluizen volledig open en wordt de maximale getijslag bereikt $(\mathrm{ca} 140 \mathrm{~cm})$, waarbij in het Klimaatscenario de effecten van zeespiegelstijging en veranderde rivierafvoer zijn meegenomen. De variant $80 \mathrm{~cm}$ getij is een tussenvariant waarbij een getijslag van 0,8 tot 1 meter wordt bereikt in het onderzoeksgebied.

Voor iedere variant zijn op een aantal locaties de waterstanden berekend met een 1D hydrodynamisch model, met een tijdstap van 10 minuten over een periode van 10 jaar. Met de aansturing van de Haringvlietsluizen als stormvloedkering neemt de getijslag met ca $80-90 \mathrm{~cm}$ toe ten opzichte van de getijslag bij de varianten Huidig beheer en Kierbesluit ( $40-50 \mathrm{~cm}$ getijslag). In de variant $80 \mathrm{~cm}$ getij neemt de getijslag met ongeveer $35 \mathrm{~cm}$ toe ten opzichte van de varianten Huidig beheer en Kierbesluit. Als gevolg van de verminderde opstuwende werking van de Haringvlietsluizen door het verder openzetten daalt het de middenstand over het hele onderzoeksgebied met 10 tot $15 \mathrm{~cm}$ bij de varianten $80 \mathrm{~cm}$ getijslag en Stormvloedkering. Bij de variant Klimaatscenario stijgt de middenstand met ca $35 \mathrm{~cm}$ ten opzichte van het Huidig beheer ten gevolge van de $40 \mathrm{~cm}$ zeespiegelstijging op de Noordzee (KNMI warme variant voor het jaar 2050).

De door het 1D hydrodynamisch model berekende waterstanden zijn gebruikt om de verandering in potentiële getijdenatuur voor de verschillende varianten in kaart te brengen. Het intergetijdengebied is daarbij opgedeeld in verschillende ecotopen: Permanent intergetijdengebied, Zomer intergetijdengebied en Hoog intergetijdengebied. Het potentieel areaal intergetijden-ecotoop in het volledige onderzoeksgebied neemt toe van 6513 ha in de varianten Huidig beheer en Kierbesluit naar 7774,8354 en 7946 ha in respectievelijk de varianten $80 \mathrm{~cm}$ getij, Stormvloedkering en Klimaatscenario. De grootste toename wordt verkregen in het Haringvliet en de Biesbosch. In het Haringvliet komt er bij de varianten $80 \mathrm{~cm}$ getij, Stormvloedkering en Klimaatscenario respectievelijk 538, 825 en 657 ha bij ten opzichte van de varianten Huidig beheer en Kierbesluit). De toename aan potentieel intergetijdengebied komt voornamelijk ten goede aan het ecotoop Permanent intergetijdengebied. Dit is vooral het geval in de variant Klimaatscenario waar $92 \%$ van het intergetijdengebied bestaat uit het ecotoop Permanent intergetijdengebied. De gemodelleerde arealen van de potentiële intergetijdengebieden moeten wel met de nodige voorzichtigheid behandeld worden. Lokale topografie, bijvoorbeeld het voorkomen van oeverwallen of dijkjes kan het daadwerkelijk overstromen van een bepaald gebied beperken of verhinderen. Hier is bij de huidige analyses geen rekening mee gehouden. Mogelijk zijn er maatregelen nodig, zoals het weggraven van oeverwallen of andere hoger gelegen delen, zodat het water de potentiële intergetijdengebieden kan bereiken. Ook de wijze waarop de variërende middenstand is verwerkt in de modellering, kan in een afwijking resulteren. Aanbevolen wordt om in een vervolgstudie de berekende arealen in de Huidige situatie in meer detail te vergelijken met de geobserveerde arealen.

In de varianten $80 \mathrm{~cm}$ getij en Stormvloedkering gaat de toename aan potentiële intergetijdengebieden ten koste van de arealen open water en terrestrische ecotopen. In het 
Haringvliet komt een deel rond de Ventjagersplaten en de Slijkplaat, wat in de huidige situatie permanent onder water staat, periodiek droog te vallen tijdens laagwater. Rond Tiengemeten en in het Hollands Diep zullen er delen die in de huidige situatie permanent droog staan juist periodiek overstromen tijdens hoogwater. Het ecotoop Hoog intergetijdengebied in het Haringvliet en Hollands Diep neemt toe in de variant $80 \mathrm{~cm}$ getij ten opzichte van de variant Huidig beheer (respectievelijk 45 en $37 \mathrm{ha}$ ). In de Biesbosch neemt het areaal Hoog intergetijdengebied echter af met 329 ha en veranderd grotendeels in het ecotoop Zomer droog. Het areaal Hoog intergetijdengebied verdwijnt grotendeels in de variant Klimaatscenario (netto afname van 1403 ha 84\%) en wordt overgenomen door het ecotoop Permanent intergetijdengebied.

Naast een indeling op basis van overspoeling is er ook een onderscheid gemaakt tussen brakke en zoete ecotopen. De zoutindringing is geschat op basis van deskundigen oordeel, ondersteund met metingen uit de periode kort voor de sluiting van het Haringvliet. Dit geeft een grove indicatie tot waar zoutinvloed te verwachten is en waar zich dus mogelijk brakwater ecotopen kunnen ontwikkelen.

Omdat het toelaten van extra getij via de Haringvlietsluizen tot doel heeft extra getijdenatuur te creëren is er een (deskundigen)inschatting gemaakt van de natuur die zich in potentie zou kunnen ontwikkelen binnen de intergetijde-ecotopen. De zoutindringing zal leiden tot een verschuiving van zoetwatersoorten (bijv. korfschelpen, driehoeksmosselen, quaggamosselen) naar typische brakwatersoorten, zoals zeeduizendpoot, slijkgarnalen, steurgarnalen, die kunnen omgaan met een brede saliniteitsrange en schommelingen in zoutgehalte. De verwachting is dat de zoutgehaltes te laag en te variabel zullen zijn voor de ontwikkeling van echte mariene soorten. Het verdwijnen van driehoeks- en quaggamosselen kan mogelijk een negatief effect hebben op duikeenden als kuif- en tafeleend. In de ecotopen hoog in het intergetijdengebieden (Hoog intergetijdengebied en Zomer droog) zal zich vegetatie kunnen ontwikkelen, waarbij meer pioniersvegetaties zich zullen ontwikkelen binnen het ecotoop Zomer droog. Successie op schorren leidt vroeg of laat tot monotone, vaak mono specifieke vegetaties van riet (brakwaterschorren) of wilg (zoetwaterschorren). Beheer is een belangrijke factor in het behoud va structurele en biologische diversiteit. De ontwikkeling in vegetatie zal zich doorvertalen naar broedvogels die gebruik maken van deze ecotopen. Zoetwater en brakwaterschorren zijn belangrijk voor broedende riet- en moerasvogels zoals kiekendief, blauwborst, rietzanger, bosrietzanger, rietgors, cetti's zanger en baardmannetje. Door de vegetatieontwikkeling binnen het ecotoop Zomer droog zal, zonder beheer, de geschiktheid van het gebied voor kustbroedvogels beperkt zijn. Tijdens laagwater vormen de slikken en platen in het permanent intergetijdengebied een geschikt foerageergebied voor allerlei soorten steltlopers en watervogels. Tijdens hoogwater kunnen vissen in het gebied foerageren op de aanwezige bodemdieren. Bepaalde belangrijke prooisoorten voor steltlopers (e.g. scholekster en wulp), zoals wadpieren, kokkels en mosselen zullen zich naar alle waarschijnlijkheid niet vestigen in de brakke intergetijdengebieden omdat de zoutgehaltes te laag zijn.

In de huidige situatie is er sprake van zandhonger in het gebied. Het terugbrengen van getijdynamiek zal de zandhonger verminderen maar niet doen verdwijnen. Daarvoor zijn de stroomsnelheden te laag. Zelfs in de variant Stormvloedkering zal er naar verwachting onvoldoende stroomsnelheid in het systeem terugkomen om de natuurlijke plaatopbouw terug te krijgen. Gezien de huidige sedimentatiesnelheid in het Haringvliet en Hollands Diep $\left(0,2\right.$ tot $2 \mathrm{~cm}$ jaar $\left.^{-1}\right)$ zal de bodem in het subtidaal naar verwachting wel kunnen meegroeien met de zeespiegelstijging waardoor de zandhonger niet zal toenemen.

Toename van de getijvariatie in het Haringvliet en Hollands Diep zal leiden tot een verdeling van de erosieve werking van de golven over een groter bereik waardoor de erosie van onbeschermde oevers afneemt en het talud van de oevers minder steil worden. Op dit moment zijn de meeste oevers in het Haringvliet en Hollands diep kunstmatig beschermd met oeverbekleding of vooroeverbescherming. Op locaties met vooroeverbescherming kan met name fijn sediment worden ingevangen achter de beschermingen. Voor de variant Stormvloedkering wordt verwacht dat er meer slib kan worden ingevangen omdat het aanbod van slib en het uitwisselingsdebiet met het gebied achter de vooroeverbescherming zullen toenemen. Aandachtspunt is wel de stabiliteit van de vooroeverbescherming, welke in de huidige situatie gedeeltelijk verzakt is. Door toename van de stroomsnelheden kan de stabiliteit verder afnemen. 
Om de zandhonger in het Haringvliet en Hollands Diep tegen te gaan zijn aanzienlijke hoeveelheden zand nodig. Huidig sedimenttekort bedraagt namelijk ongeveer $1.000 \mathrm{Mm}^{3}$ en zal naar schatting $400 \mathrm{Mm}^{3}$ bedragen voor de variant Stormvloedkering. Dergelijke suppleties brengen aanzienlijke kosten met zich mee. Maatregelen gericht op het mitigeren van de negatieve gevolgen van de zandhonger zijn daarom kostenefficiënter. Met betrekking tot de ecologische functie van het Haringvliet is het grootste nadeel van de zandhonger dat het plaatareaal met een gunstige droogvalduur voor bijvoorbeeld het foerageren door vogels afneemt. Met lokale zandsuppleties kunnen de negatieve effecten van de plaaterosie worden beperkt doordat meer intergetijdengebied met juiste droogvalduur gecreëerd wordt. In 2008 heeft een succesvolle proef ten aanzien van lokale zandsuppleties plaatsgevonden in de Oosterschelde, waarbij $130.000 \mathrm{~m}^{3}$ sediment is gesuppleerd op de Galgenplaat. Ook in de Schelphoek en bij de Oesterdam zijn suppleties uitgevoerd om de erosie van de slikken tegen te gaan. Dit heeft positieve gevolgen gehad voor de ecologie. Daarom zal naar verwachting in de winter van 2019 een nieuwe suppletie van 1,3 $\mathrm{M} \mathrm{m}^{3}$ worden uitgevoerd op de Roggenplaat (Oosterschelde).

Het verder openzetten van de Haringvlietsluizen zal ook effect hebben op de morfologie van de buitendelta. Zelfs wanneer de sluizen weer volledig geopend zullen worden (variant Stormvloedkering) zal het gebied niet terugkeren naar de situatie van voor de afsluiting, omdat enerzijds de vele ingrepen het gebied (e.g. Maasvlakte II) onomkeerbaar veranderd hebben en anderzijds de dam een barrière zal blijven vormen voor water- en sedimentuitwisseling. Omdat door het openen van de sluizen het getijvolume zal toenemen, wordt verwacht dat de bestaande geulen minder sterk zullen aanzanden of weer zullen verruimen. 


\section{$1 \quad$ Inleiding}

\section{$1.1 \quad$ Achtergrond}

Vanaf 2018 gaan de Haringvlietsluizen op een kier (Astma, 2011). De Kier is vooral ingegeven vanuit de voorspelde positieve effecten van deze maatregelen op de natuur, met name het herstel van vismigratie (Van Leeuwen et al., 2004; Platteeuw and Cornelissen, 2005; Paalvast, 2016). Dit echter onder de randvoorwaarden van het behoud van mogelijkheden voor zoetwaterinname, scheepvaart en veiligheid. Om aan dit doel niet voorbij te gaan en aan de gestelde voorwaarden te blijven voldoen wordt de Kier via lerend implementeren (adaptieve implementatie) door Rijkswaterstaat gaandeweg ingevoerd. De Kier houdt in dat een deel van de spuisluizen tijdens vloed in beperkte hoogte (niet geheel) worden opengezet, zodat niet alleen tijdens spuien (bij laag water) een verbinding voor trekvissen ontstaat richting zee (wat nu het geval is), maar ook tijdens vloed richting Rijn en Maas (De Goederen et al., 2006). Trekvissen als zalm en zeeforel en zout-tolerante zoetwatervissen als karper en snoekbaars kunnen door de Kier en de spuisluizen makkelijker in beide richting passeren (Griffioen et al., 2017). Zout water van de Noordzee mag het Haringvliet binnenstromen, daarbij wordt een zoutgradiënt toegelaten tot maximaal aan de lijn Spui-Middelharnis (tot ca. $13 \mathrm{~km}$ ten oosten van de Haringvlietdam) omwille van de zoetwaterinnamefunctie.

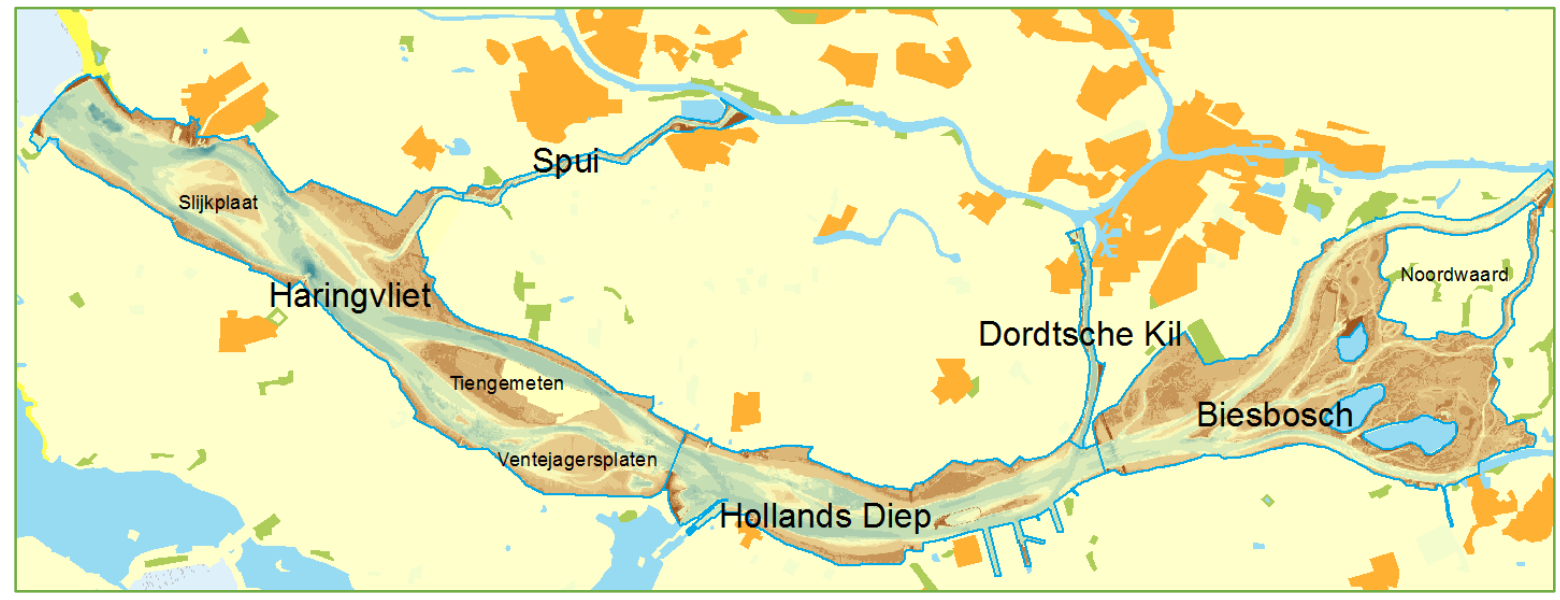

Figuur 1 Onderzoeksgebied met onderscheid van de vijf deelgebieden Haringvliet, Spui, Hollands Diep, Dordtsche Kil en Biesbosch.

Naast het herstel van vismigratie heeft de Kier ook als doel om tot een gedeeltelijk herstel van de estuariene dynamiek te komen in het Haringvliet, en mogelijk de aangrenzende wateren als het Spui, de Dordtsche Kil, het Hollands Diep en de Biesbosch (onderzoeksgebied, Figuur 1). Hierdoor zal er naar verwachting meer intergetijdengebied ontstaan wat daarmee kan bijdragen aan de specifieke natuurwaarden van dit deltagebied. Het WNF wil in het kader van het Droomfondsproject verder laten onderzoeken welke mogelijkheden er zijn voor het herstel van getijdennatuur in het Haringvliet, Spui, Hollands Diep, Dordtsche Kil en Biesbosch.

\subsection{Doelstelling van deze studie}

Het doel van deze studie is te onderzoeken in hoeverre het toelaten van getij, (deels) openzetten van de Haringvlietsluizen in potentie kan leiden tot een toename van het areaal intergetijdengebied binnen het onderzoeksgebied. Tevens zal er een inschatting worden gemaakt welke types intergetijdengebied er zich zullen ontwikkelen (in relatie tot zoutgehalte, hoogteligging). Hierbij zal ook worden gekeken naar de effecten van klimaatverandering (zeespiegelstijging en veranderende rivierafvoeren). 


\subsection{Onderzoeksvragen}

Voor de uitvoering van dit onderzoek zijn de volgende onderzoeksvragen geformuleerd:

1. Waar liggen de potenties voor intergetijdengebieden bij verschillende varianten van sluisbeheer en welke arealen zijn hierbij in potentie mogelijk?

2. Welke natuurwaarden kunnen er ontstaan binnen de intergetijdengebieden, rekening houdend met zoutfluctuaties, ontwikkeling bodemleven, voedselbeschikbaarheid voor vogels en broedmogelijkheden voor vogels?

3. Is het mogelijk om met een grotere sluisopening, en de daaraan gekoppelde verhoging van de getijdynamiek de natuurlijke plaatopbouw terug te krijgen? Zo nee, welke aanvullende maatregelen zijn er mogelijk om plaatopbouw te stimuleren?

4. Nemen de effecten van de zandhonger in het Haringvliet toe als gevolg van zeespiegelstijging? Zo ja, welke maatregelen zijn er mogelijk om de negatieve effecten hiervan te mitigeren?

5. Wat zijn de mogelijke morfologische gevolgen van een ander beheer van de Haringvlietsluizen voor de buitendelta van het Haringvliet?

\section{$1.4 \quad$ Methodiek}

In deze studie zijn de effecten van vier varianten op de ligging, areaal en kwaliteit van de intergetijdengebieden geëvalueerd. De varianten verschillen van elkaar met betrekking tot getijslag en middenstand. De basis variant is het Huidig beheer, waarbij er een beperkte getijslag is in het onderzoeksgebied. De variant Kierbesluit is de situatie na de invoering van het Kierbesluit. Vervolgens zijn er twee varianten doorgerekend met een toenemende getijslag (variant $\mathbf{8 0} \mathbf{~ c m}$ getij en variant Stormvloedkering). Ten slotte is er een stormvloedkering variant doorgerekend waarin ook de gevolgen van klimaatveranderingen (zeespiegelstijging veranderde rivierafvoeren) zijn meegenomen (variant Klimaatscenario). De laatste variant behelst de verwachte situatie in 2050 voor klimaatscenario warm.

Om het effect van de verschillende varianten op de ligging en het areaal van de intergetijdengebieden te onderzoeken, is er gebruik gemaakt van een ecotopenbenadering. De intergetijdengebieden worden ingedeeld in verschillende ecotopen op basis van overspoelingsduur en zoutgehalte. Deze aanpak is overeenkomstig de aanpak die is gebruikt in de studie "Samenhang in de Delta" (Ysebaert et al., 2013a; Ysebaert et al., 2013b; Ysebaert et al., 2016), waarbij de ecotopenindeling is gebaseerd op de ecotopenindeling zoals gedefinieerd in het "Zoute wateren Ecotopen Stelsel" (Bouma et al., 2005). De redeneerlijn die is gevolgd voor het bepalen van de te verwachten ecotopen in deze studie is schematisch weergegeven in Figuur 2.

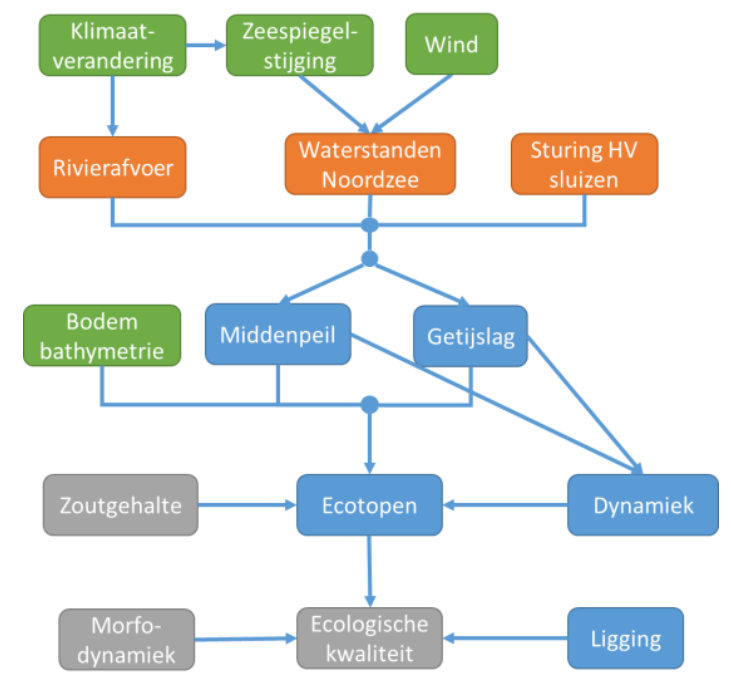

Figuur 2 Schematisch overzicht van de gevolgde methodiek in deze studie. De randvoorwaarden voor het model zijn in het groen aangegeven. De (stuur)variabelen zijn weergegeven met de oranje blokken. In het grijs staat weergegeven wat gebaseerd is op basis van deskundigen-oordeel. In het blauw ten slotte staat wat met de modellen is berekend. 
De waterstanden in het onderzoeksgebied zijn voor de varianten Huidig beheer, $80 \mathrm{~cm}$ getij, Stormvloedkering en Klimaatscenario berekend met behulp van een 1D hydrodynamisch model (SOBEK). Voor de variant Kierbesluit is voor deze studie aangenomen dat de waterstanden niet anders zullen zijn dan bij de variant Huidig beheer. De modelberekeningen zijn uitgevoerd voor een periode van 10 jaar (02-01-1996 tot en met 31-12-2006) om zoveel mogelijk verschillende condities mee te nemen in de analyse. Met het model is de waterstand iedere 10 minuten voor 7 verschillende locaties binnen het onderzoeksgebied (Figuur 3) berekend en uitgevoerd.

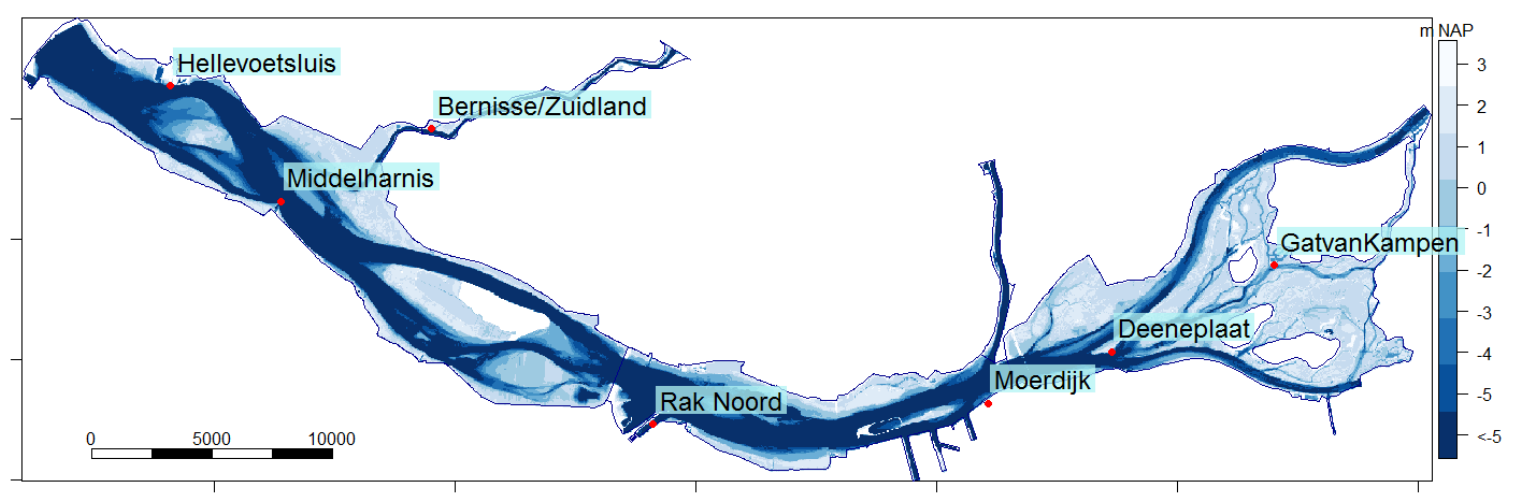

Figuur 3 Dieptekaart (m NAP) van het modelgebied zoals het is gebruikt voor deze studie. In de figuur zijn tevens de locaties gegeven waarvan de waterstanden zijn berekend met het 1D hydrodynamisch model.

De dynamiek in waterstanden wordt gekarakteriseerd door de (dynamiek) in de variabelen middenstand en getijslag. De getijslag en middenstand worden bepaald door: (1) rivierafvoer (2) waterstanden op de Noordzee en (3) sturing met behulp van de Haringvlietsluizen (Figuur 2). De varianten die in deze studie zijn doorgerekend onderscheiden zich in deze drie stuurvariabelen. Voor de varianten Huidig beheer, Kier, $80 \mathrm{~cm}$ getijslag en Stormvloedkering is in het model alleen de sturing middels de Haringvlietsluizen gevarieerd. De waterstanden op de Noordzee zijn afhankelijk van de wind en, in het geval van de variant Klimaatscenario, van de veranderingen in zeespiegelstijging en rivierafvoer.

De ecotopen zijn berekend uit de berekende waterstanden, de huidige dieptekaart (Figuur 3) en een deskundigen inschatting van de indringing van het brakwater binnen het onderzoeksgebied. De ecotopenclassificatie die is gebruikt in deze studie is gebaseerd op een aantal getijstatistieken (zoals Gemiddeld Laag Water, Gemiddeld Hoog Water, etc.). Deze getijstatistieken zijn voor de 7 modellocaties herleid uit de door het 1D model berekende waterstanden. Om tot een gebiedsdekkend beeld te komen zijn de getijstatistieken vervolgens geïnterpoleerd over het hele modelgebied. De intergetijdengebieden zijn in kaart gebracht door de geïnterpoleerde getijstatistieken (e.g. Gemiddeld Laag water, Gemiddeld Hoog Water) te combineren met de bathymetriekaart. De ecotopenkaarten geven de ligging en het areaal van de verschillende ecotopen in het onderzoeksgebied. Omdat zoete en brakke getijdesystemen zeer verschillend zijn wat betreft flora en fauna is de ligging van de zoutgrens bij de verschillende varianten (inschatting door deskundigen) meegenomen in de analyse.

De ecologische kwaliteit van de intergetijdengebieden is tevens afhankelijk van morfologische processen (bijv. erosie als gevolg van zandhonger) en de ligging van het intergetijdengebied (bijvoorbeeld bodemprofiel, verhang, hoogteligging, etc.). Een intergetijdengebied dat bijvoorbeeld sterk onderhevig is aan erosie zal minder lang standhouden of heeft onderhoud nodig. De morfodynamiek in het onderzoeksgebied is beschreven op basis van deskundigen-oordeel.

Door de ecotopenkaarten van de verschillende varianten met elkaar te vergelijken wordt inzicht verkregen in het effect van de varianten op het areaal en de ligging van de ecotopen en daarmee de ecologische kwaliteit van de potentiële intergetijdengebieden.

Deze aanpak geeft inzicht in het potentieel aan intergetijdengebied op basis van de hoogteligging en de berekende waterstandfluctuaties. Er is niet onderzocht of het water de potentiële 
intergetijdengebieden daadwerkelijk kan bereiken. Mogelijk verhinderen wallen, dijkjes of andere hoger-gelegen delen dat het water de potentiële intergetijdengebieden bereikt. Zonder ingrepen (e.g. weggraven van deze obstructies) zal het werkelijke intergetijdengebied kleiner zijn dan het in deze studie berekende potentieel aan intergetijdengebied.

\subsection{Afbakening}

Deze studie richt zich op de mogelijkheden van het potentieel herstel van getijdenatuur in het onderzoeksgebied middels het toelaten van getij via de Haringvlietsluizen. Voor een aantal varianten is de getijdenatuur gekwantificeerd op basis van een combinatie van modelberekeningen, literatuur en deskundigen-oordeel. In deze studie is daarbij gebruik gemaakt van een 1D hydrodynamisch model om de waterstanden te berekenen. Zoutverspreiding in het Haringvliet vraagt om een 3D-model aanpak en kan niet met een 1D model worden gemodelleerd. De zoutconcentraties die zijn gebruikt in deze studie zijn dan ook gebaseerd op inschattingen door deskundigen.

Deze studie is vooral gericht op de effecten van het terugbrengen van getijdendynamiek op de getijdenatuur binnen het modelgebied (Haringvliet, Hollands Diep, Biesbosch, Spui en Dordtsche Kil). Eventuele effecten op de natuur in de Voordelta blijven hier buiten beschouwing. Wel is er op basis van een deskundigen-oordeel ingeschat wat de morfologische effecten zijn op de buitendelta.

Voor de ligging en het areaal van de ecotopen is er in deze studie is geen rekening gehouden met mogelijke veranderingen van de bodem als gevolg van het terugbrengen van het getij. Er is voor alle varianten gebruik gemaakt van dezelfde dieptekaart, welke is gebaseerd op de dieptekaart die is gebruikt in de studie van Ysebaert et al. (2013a).

\subsection{Leeswijzer}

Dit onderzoek is uitgevoerd door een samenwerking van Wageningen Marine Research (WMR) en Deltares. Een beschrijving van het modelgebied is gegeven in hoofdstuk 2 en de varianten die in deze studie zijn uitgewerkt zijn beschreven in hoofdstuk 3. In hoofdstuk 4 is het hydrodynamisch model beschreven en zijn de resultaten van het model gepresenteerd. De zoutindringing in het gebied is gebaseerd op basis van een inschatting door deskundigen. Deze inschatting is gepresenteerd in §4.5. De morfologische aspecten van het terugbrengen van meer getij zoals zandhonger, bodembescherming en effecten op de buitendelta worden besproken in hoofdstuk 5. De ecotopen die de resultante zijn van de waterstanden enerzijds en de zoutindringing anderzijds zijn gepresenteerd en besproken in hoofdstuk 6 . In $§ 6.4$ is daarbij een vertaling gemaakt naar de natuurwaarde van de ecotopen. In hoofdstuk $\S 7$ tenslotte worden de onderzoeksvragen van $\S 1.3$ beantwoord en worden de resultaten bediscussieerd.

\subsection{Dankwoord}

Bas Roels (WNF) en Barbara Schoute (Natuurmonumenten) hebben het project begeleidt. Sacha de Goederen (RWS), Michiel van den Bergh (WNF) en Frans van Zijderveld (Natuurmonumenten) willen we danken voor hun waardevolle inbreng tijdens de workshops. De bijdragen van Deltares zijn aanvullend intern geborgd door Jebbe van der Werf, Theo van der Kaaij en Frans Buschman (Deltares). 


\section{Onderzoeksgebied}

Het onderzoeksgebied bevat de gebieden Haringvliet, Hollands Diep, (Brabantse) Biesbosch, Spui en Dordtsche Kil (Figuur 2). Na de aanleg van de Haringvlietdam (1970) hebben de Haringvliet, Hollands Diep en Biesbosch zich ontwikkeld tot zoete wateren met een nog zeer gering getij. Het Spui en De Dordtsche Kil verbinden het Haringvliet en het Hollands Diep met de Oude Maas. Er is nog een beperkt getij aanwezig van ca $40 \mathrm{~cm}$ in het gebied via de verbinding met de Nieuwe-Waterweg via de Dordtse Kil en het Spui. In het geval dat er meer getijdewater wordt toegelaten door de Haringvlietsluizen vanuit de Noordzee zullen de gebieden binnen het onderzoeksgebied in meer of mindere mate onder invloed komen te staan van getij. In 2018 zullen de Haringvlietsluizen op een kier worden gezet waardoor de migratiemogelijkheden voor vis zullen verbeteren (Griffioen et al., 2017). Tevens zal er zoutindringing plaatsvinden in het westelijk deel van de Haringvliet tot maximaal de lijn tussen Spui en Middelharnis.

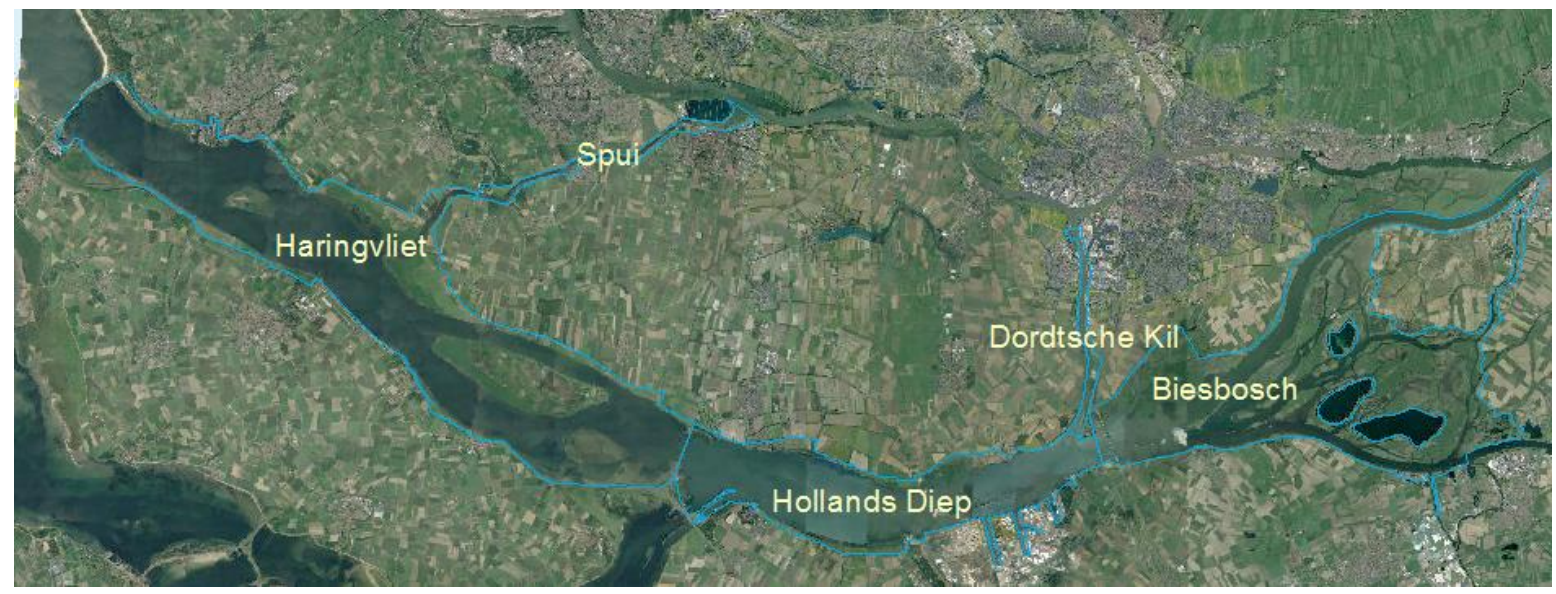

Figuur 4 Ligging van de verschillende deelgebieden in het onderzoeksgebied (bron Google Earth (c).

\section{Haringvliet}

Het Haringvliet is een voormalig estuarium, gelegen tussen Voorne putten en Hoeksche Waard in het Noorden en Goeree-Overflakkee in het zuiden waar een deel van het water van de rivieren Maas en Rijn de Noordzee in stoomt. In 1970 is het Haringvliet in het kader van de Deltawerken afgesloten van de Noordzee door de bouw van de Haringvlietdam (geopend in 1971). Tussen 1970 en 1971 fungeerde de Haringvlietsluizen als een stormvloedkering. Door het verdwijnen van het getij is van het 13.700 ha buitendijkse intergetijdengebied ca 1.850 ha permanent droog komen te liggen en de rest permanent onder water. Om het water van de rivieren de Maas en de Rijn te kunnen lozen is gekozen voor een sluizencomplex dat ca 25.000 kubieke meter water per seconde kan doorlaten, terwijl er bij vloed op de Noordzee geen zout water mag binnendringen. Het waterpeil wordt beïnvloed door de stand van de Haringvlietsluizen, de waterstanden op de Noordzee en de aanvoer van rivierwater vanaf de Maas en Rijn. De Haringvlietsluizen zijn bij vloed en lage rivierafvoeren gesloten (zie §3.1 voor een meer gedetailleerde beschrijving). Het zoete water wordt dan via de Nieuwe-Waterweg geleid om ervoor te zorgen dat de zouttong niet te ver de Nieuwe Waterweg en de Nieuwe Maas binnendringt.

\section{Hollands Diep}

Het Haringvliet gaat over in het Hollands Diep bij de Haringvlietbrug. Het deelgebied Hollands Diep zoals we het gebruiken binnen deze studie loopt vanaf de Haringvlietbrug tot net voorbij de aftakking van de Dordtsche Kil. Langs de zuidzijde van het Hollands Diep ligt het industriegebied Moerdijk. Op de bodem van het Hollands Diep is een met zware metalen vervuilde sliblaag aanwezig die een erfenis is van de vervuiling vanuit de rivieren in de jaren '70. Deze sliblaag is inmiddels afgedekt als gevolg van natuurlijke afzetting van een schonere sliblaag uit de latere jaren (Mulder et al., 2010). 


\section{Biesbosch}

De Biesbosch is een belangrijk natuurgebied waar water, rietlanden en kreken elkaar afwisselen. Het gebied staat onder invloed van een beperkt getij. De drie bekkens in de Biesbosch (De Gijster, Honderd en Dertig en Petrusplaat) alsmede de ontpolderde polder Noordwaard vallen buiten het modelgebied. De polder Noordwaard bevat tal van kreken waar het getij sinds eind 2015 kan binnendringen. Het areaal intergetijdengebied in de Biesbosch wordt door het niet meenemen van de Noordwaard dus onderschat. Het totaal oppervlak van de Noordwaard is $4.450 \mathrm{ha}^{1}$. De Sliedrechtse Biesbosch, ten noorden van de Nieuwe Merwede behoort niet tot het onderzoeksgebied. Het onderzoeksgebied omvat dus alleen de Brabantse Biesbosch.

\section{Spui}

Het Spui verbindt het Haringvliet met de Oude Maas. Via het Spui wordt het getij van Hoek van Holland doorgegeven naar het Haringvliet.

\section{Dordtsche Kil}

De Dordtsche Kil verbindt het Hollands Diep met de Oude Maas.

\footnotetext{
${ }^{1}$ https://www.ruimtevoorderivier.nl/project/ontpoldering-noordwaard/
} 
In deze studie zijn vijf varianten doorgerekend. Er is hierbij gekozen voor een aantal extreme varianten om het potentieel in kaart te brengen. Er is hierbij geen rekening gehouden met allerlei randvoorwaarden zoals zoetwatervoorziening, scheepvaart, veiligheid, etc.

De volgende varianten zijn in deze studie meegenomen:

1. Huidig beheer: Deze variant representeert de huidige situatie. Er is sprake van een beperkte getijslag als gevolg van de indringing van het getij via Spui en Dordtsche Kil.

2. Kierbesluit: Deze variant beschrijft de situatie na de invoering van het Kierbesluit. Bij deze variant is aangenomen dat de getijslag en -dynamiek hetzelfde is als de variant huidig beheer (referentie m.e.r.). Het verschil met de variant Huidig beheer is dat zout wordt toegelaten in het westelijk deel van het Haringvliet.

3. $\mathbf{8 0} \mathbf{~ c m ~ g e t i j : ~ B i j ~ d e z e ~ v a r i a n t ~ w o r d t ~ e x t r a ~ g e t i j ~ t o e g e l a t e n ~ d o o r ~ d e ~ H a r i n g v l i e t s l u i z e n ~ c o n t i n u ~}$ gedeeltelijk open te zetten. De getijamplitude in het Haringvliet is ongeveer $80 \mathrm{~cm}$.

4. Stormvloedkering: Bij deze variant fungeren de Haringvlietsluizen als een stormvloedkering. De sluizen staan continu maximaal open. Alleen bij een waterstand van +2 meter NAP bij Hoek van Holland gaan de sluizen dicht.

5. Klimaatscenario: Deze variant beschrijft de situatie waarbij de Haringvlietsluizen worden gebruikt als stormvloedkering, waarbij de effecten van klimaatveranderingen zijn meegenomen (KNMI warme variant voor het jaar 2050).

\subsection{Huidig beheer}

Op dit moment worden de Haringvlietsluizen aangestuurd op basis van de afvoer op de Boven-Rijn en het verhang over de Haringvlietsluizen. Effectief worden alleen tijdens eb de sluizen opengezet. De mate van openen is afhankelijk van de afvoer bij Lobith (Figuur 5), vanaf $1.100 \mathrm{~m}^{3} \mathrm{~s}^{-1}$ staan de sluizen een beetje open en vanaf $9.500 \mathrm{~m}^{3} \mathrm{~s}^{-1}$ staan de sluizen volledig open. Daarnaast wordt er gestreefd naar een waterstand van tenminste 0 meter +NAP bij Moerdijk waardoor de sturing iets kan afwijken van de hiervoor genoemde regels ${ }^{2}$. Dit beheer wordt ook wel LPH '84 (LozingsProgramma Haringvlietsluizen 1984) genoemd (Van Leeuwen et al., 2004; De Goederen et al., 2006).

\footnotetext{
${ }^{2}$ In het model is gebruik gemaakt van de stuwsturing zoals opgenomen in het 2D model (WAQUA) van de Rijn-Maasmonding. Deze aansturing is speciaal voor dit project opgenomen in het SOBEK3 model. Bij deze stuwsturing wordt afhankelijk van het verhang over de Haringvlietsluizen de opening van de schuiven ingesteld op basis van de afvoer bij Tiel (Waal). Afwijkend t.o.v. de werkelijke sturing van de Haringvlietsluizen, wordt er in het model niet getracht om een waterstand van tenminste 0 meter +NAP bij Moerdijk aan te houden. Hierdoor kan de minimale waterstand in het model lager zijn dan in de werkelijkheid. Verder zal het moment waarop de mate van openen wordt bepaald in het model niet overeenkomen met de werkelijkheid omdat het maken van een precieze nabootsing van de sturing van de Haringvlietsluizen niet past binnen de scope van dit onderzoek. Hierdoor kunnen bijvoorbeeld de sluizen in het model al eerder meer water vanuit het Haringvliet spuien op de Noordzee dan in werkelijkheid. Daardoor zal de waterstand lager en de getijslag groter zijn in het model dan in de werkelijkheid.
} 


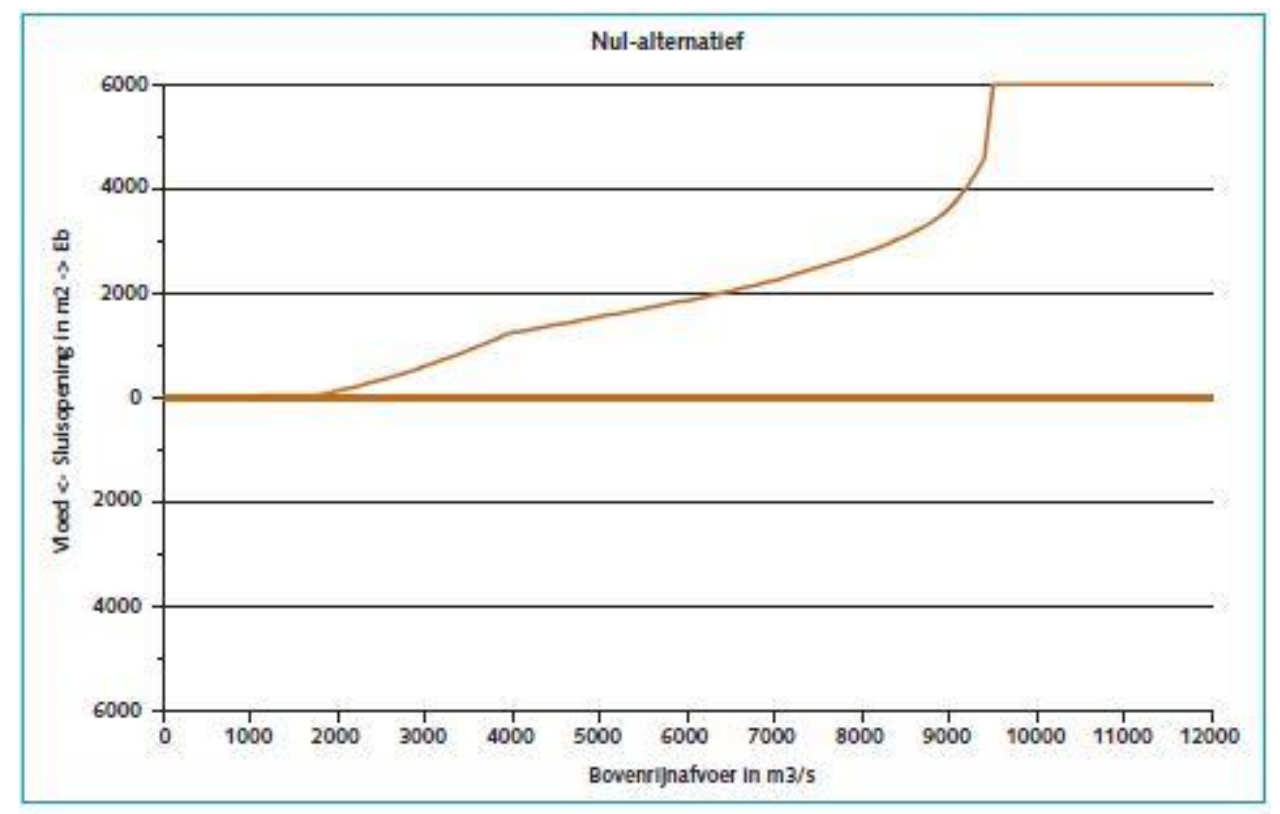

Figuur 5 Huidige opening van de sluizen (LPH '84) afhankelijk van de afvoer bij Lobith (Rijkswaterstaat, 1998d).

\section{$3.2 \quad$ Kierbesluit}

Deze variant beschrijft de situatie na de invoering van het Kierbesluit. Bij deze variant is aangenomen dat de getijslag en -dynamiek gelijk is aan de variant huidig beheer (§3.1). Het verschil met de variant Huidig beheer is dat zoutwaterindringing wordt toegelaten in het westelijk deel van het Haringvliet.

\section{$3.3 \quad 80 \mathrm{~cm}$ getij}

Dit beheer is erop gericht om een getijslag van 80 centimeter in het Haringvliet te realiseren, gemiddeld over de gehele 10 jaar aan modelresultaten. Hiervoor is een constante schuifstand van -3,75 meter +NAP gebruikt (Figuur 6). Dit betekent dat er ten alle tijden een opening van 1,75 meter door elke sluis wordt gebruikt voor deze variant. Dit komt overeen met een opening van iets meer dan $1600 \mathrm{~m}^{2}$ over de gehele breedte van de Haringvlietsluizen. Deze variant is bedoeld om een beeld te schetsen tussen de twee extremen (Huidig beheer en Stormvloedkering) in.

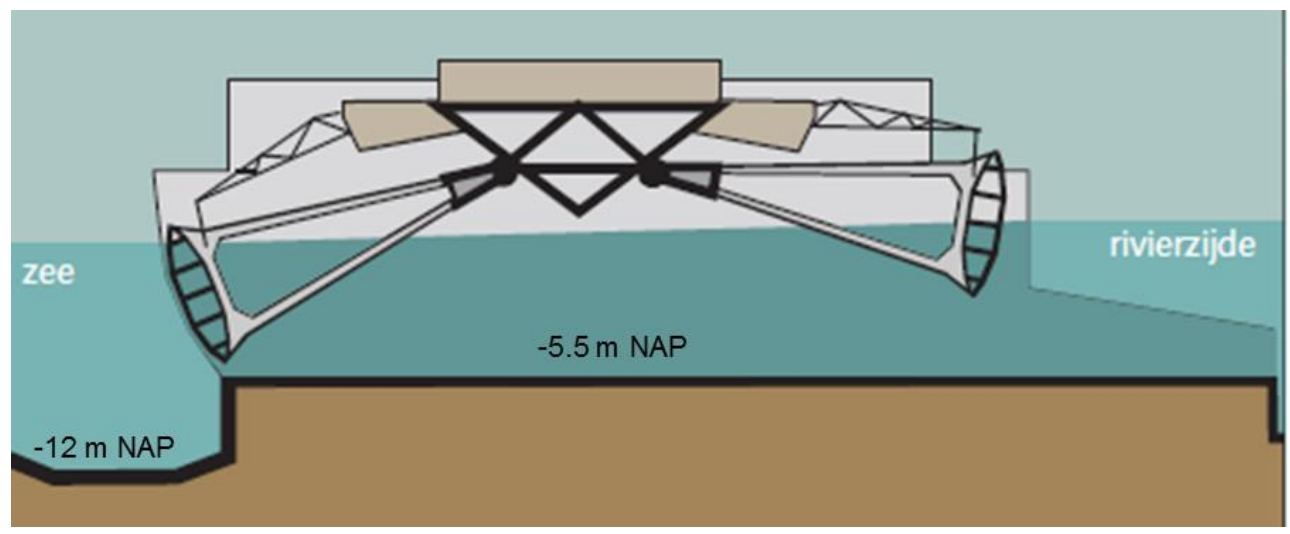

Figuur 6 Verticale doorsnede Haringvlietsluizen. Afmetingen overgenomen uit (Erdbrink and Jongeling, 2009). 


\subsection{Stormvloedkering}

Bij dit beheer functioneren de Haringvlietsluizen als een stormvloedkering vergelijkbaar met de Oosterscheldekering. De schuiven staan altijd volledig open (Figuur 7), constante schuifstand van 0,5 meter +NAP. De constructie van de Haringvlietsluizen blijft echter in de monding staan waardoor de stroming nog steeds wordt belemmerd. Bij een waterstand van meer dan 2 meter +NAP bij Hoek van Holland zullen alle schuiven direct dicht gaan om het achterliggende land te beschermen tegen de hoge waterstanden uit zee. Dit komt eens in de paar jaar voor in de doorgerekende 10 jaar. Deze variant geeft een beeld van de maximaal terug te krijgen getijinvloed in het Haringvliet waarbij de hoogwaterveiligheid vanuit zee is gegarandeerd.

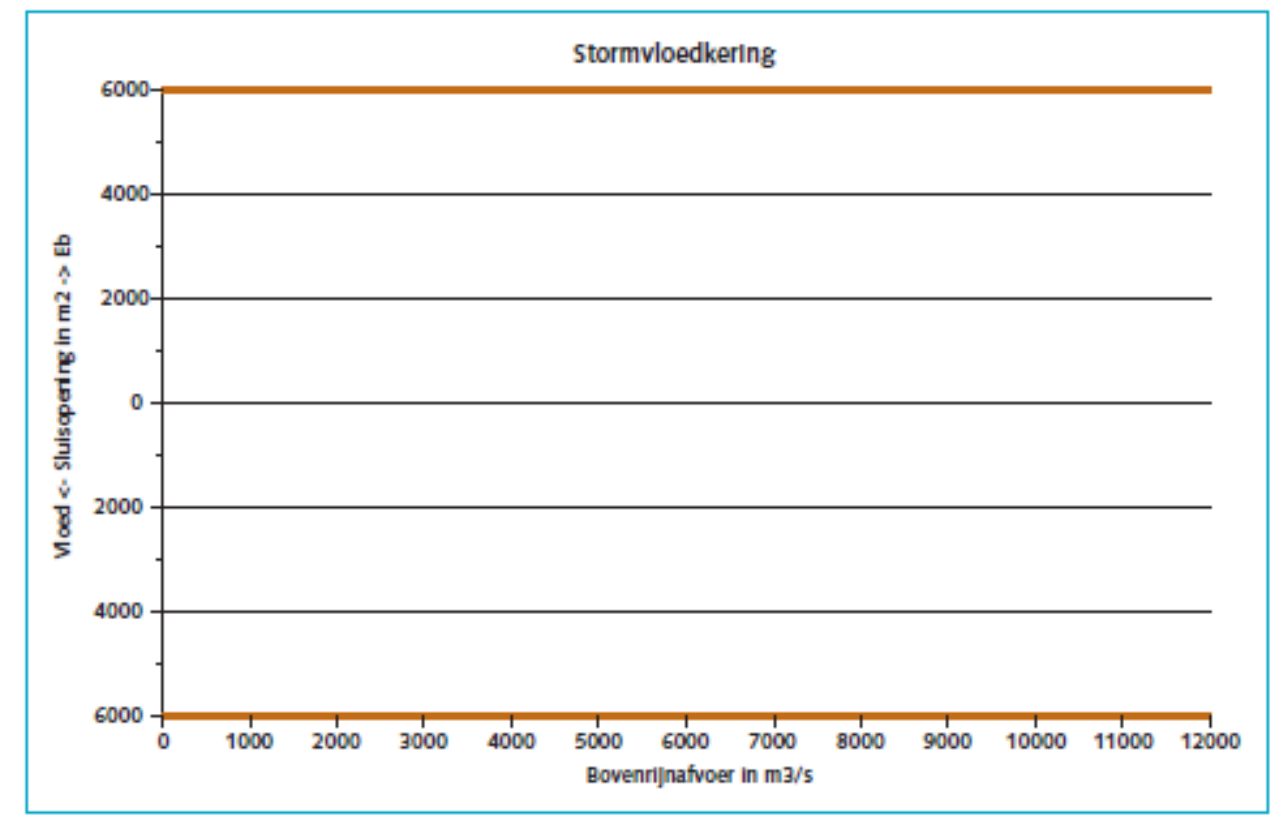

Figuur 7 Opening van de sluizen in de variant stormvloedkering (Rijkswaterstaat, 1998d).

\subsection{Klimaatscenario}

Klimaatverandering kan een grote impact hebben op de middenstand en getijslag. Middenstand en getijslag bepalen het areaal van het intergetijdengebied. Binnen dit project is daarom een klimaatscenario doorgerekend om een indicatie te geven van het areaal intergetijdengebied in de nabije toekomst. Voor deze variant is aangenomen dat de Haringvlietsluizen worden gebruikt als stormvloedkering (§3.4). Aanvullend zijn de verwachte effecten als gevolg van klimaatverandering meegenomen. Er is gebruik gemaakt van de randvoorwaarden (waterstanden en afvoeren) uit het Warm 2050 Deltascenario (Hunink and Hegnauer, 2015). Het Warm 2050 scenario houdt rekening met snelle klimaatverandering en lage mondiale economische groei. In dit scenario is er een stijgende vraag naar drinkwater en varieert de rivierafvoer over het jaar veel meer. De maximale afvoeren zullen hoger zijn terwijl de minimale afvoeren lager zullen zijn. Daarnaast stijgt de zeespiegel met $\mathbf{4 0}$ centimeter ten opzichte van de referentie in dit scenario. 


\section{$4 \quad$ Hydrodynamica en zoutgehalte}

\subsection{Model en schematisatie}

Voor dit project is gebruik gemaakt van de SOBEK3 software. SOBEK3 is een verzameling van verschillende modules die onder Deltashell (geïntegreerde modelleeromgeving) zijn samengebracht, onderdelen van SOBEK3 zijn onder andere een 1-dimensionaal hydrodynamisch model (D-Flow-1D) en een sturingsmodel voor kunst- en regelwerken (D-RTC, Berends, 2015). Elk model, de samenvoeging van verschillende modules, bevat een gebiedsbeschrijving, een zogenaamde schematisatie. Een modelschematisatie is dus de samenvoeging van software en gebiedsbeschrijving.

Voor dit project is gebruik gemaakt van een sobek-rmm-j15_5-v1 modelschematisatie (Fujisaki, 2016)(Figuur 8). Dit model geeft het jaar 2015 weer (inclusief de Noordwaard). Dit model is geschikt voor hydrodynamische scenariostudies (Rijkswaterstaat \& Deltares, 2016 - Protocol van Overdracht). Het 1D model was op het moment van de uitvoering van het project nog niet gereed om studies naar zoutverspreiding uit te voeren. Daarnaast is het Haringvliet in ieder geval moeilijk te representeren in 1D waardoor scenariostudies op het gebied van zout niet raadzaam zijn met dit model.

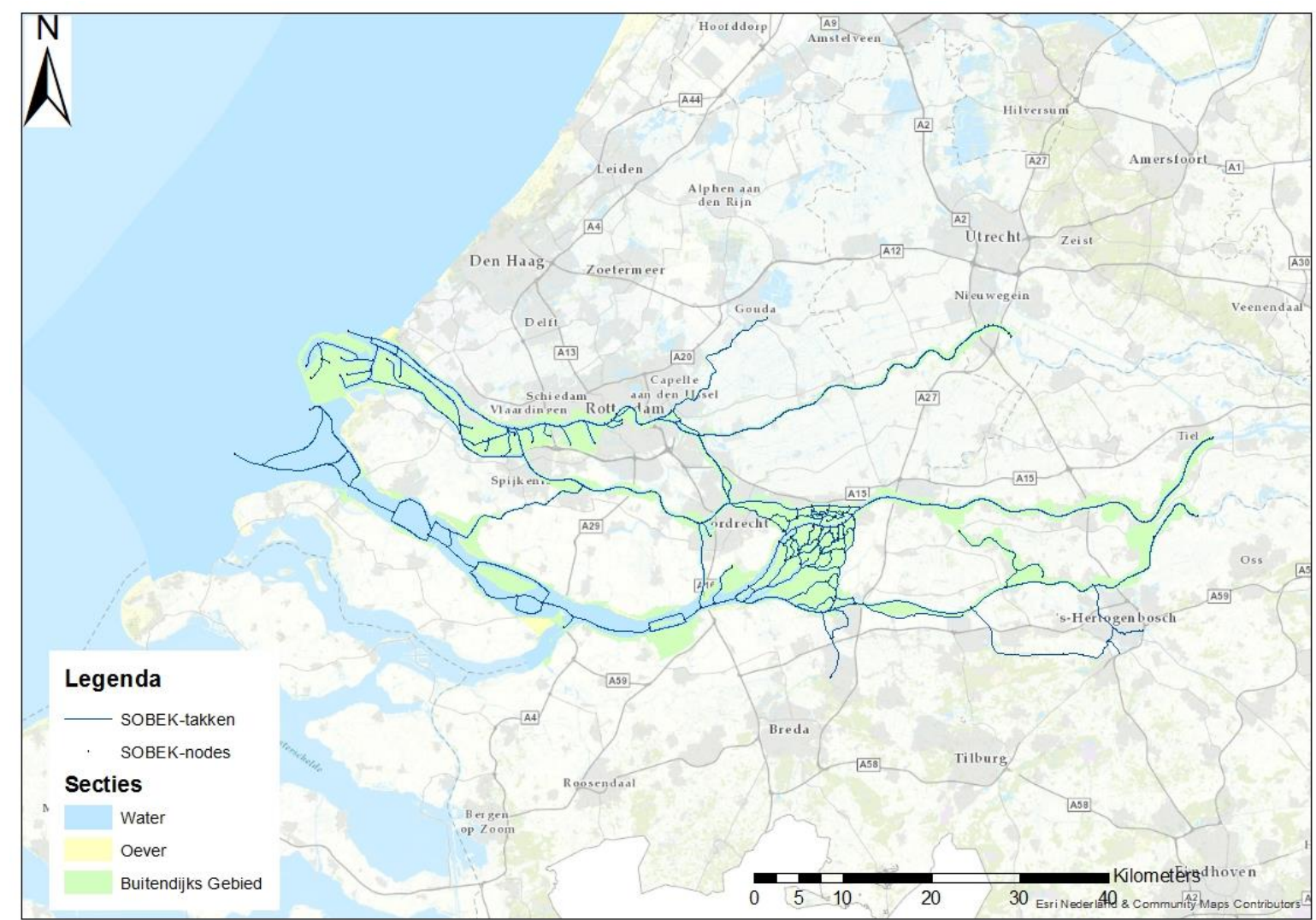

Figuur 8 SOBEK-takken van sobek-rmm-j15_5-v1 met het bereik van het model weergegeven (Fujisaki, 2016).

Bij het opzetten van het model heeft Rijkswaterstaat verzocht om de Haringvlietsluizen aan te kunnen sturen met "gemeten" schuifstanden of op basis van stationaire afvoeren. In deze studie was het noodzakelijk om de huidige stuwsturing (LPH '84) zo goed mogelijk weer te geven in het model zodat er ook op variërende afvoeren kon worden gestuurd. Zoals eerder genoemd is de sturing van elk van de sluizen aangepast. In het 2D model van de Rijn-Maasmonding (WAQUA; Zijl et al., 2011; Van der Wijk, 2015) wordt gebruik gemaakt van een actieve sturing voor elk van de sluizen op basis van het verhang over de Haringvlietsluizen en de afvoer bij Tiel. De sturing uit het 2D model is gebruikt om de sturing van het $1 \mathrm{D}$ model op te zetten. Door het overnemen van de aansturing uit WAQUA is er een 
aangepaste modelschematisatie gemaakt waarin het huidige beheer van de Haringvlietsluizen zo goed mogelijk is benaderd. Zoals eerder aangegeven zijn er enkele belangrijke verschillen die invloed kunnen hebben op de resultaten. Dit model is hierna opgeslagen in de database van Deltares en Rijkswaterstaat om voor latere scenariostudies eventueel nog te gebruiken.

\subsection{Randvoorwaarden}

Voor deze studie is een periode van 10 jaar doorgerekend om zoveel mogelijk verschillende condities mee te nemen in de analyse. Het gaat hier om een representatie van de opgetreden condities tussen 02-01-1996 en 31-12-2006 (de afvoer bovenstrooms is als voorbeeld weergegeven in Figuur 9). Vanuit het Nationaal Water Model (NWM) zijn randvoorwaarden voor de Rijn-Maasmonding aangeleverd voor deze 10 jaar. De benodigde randvoorwaarden voor de Rijn-Maasmonding zijn weergegeven in Tabel 1. De randvoorwaarden voor het klimaatscenario zijn op dezelfde manier uit het NWM gehaald. Voor alle andere varianten zijn dezelfde randvoorwaarden gebruikt.

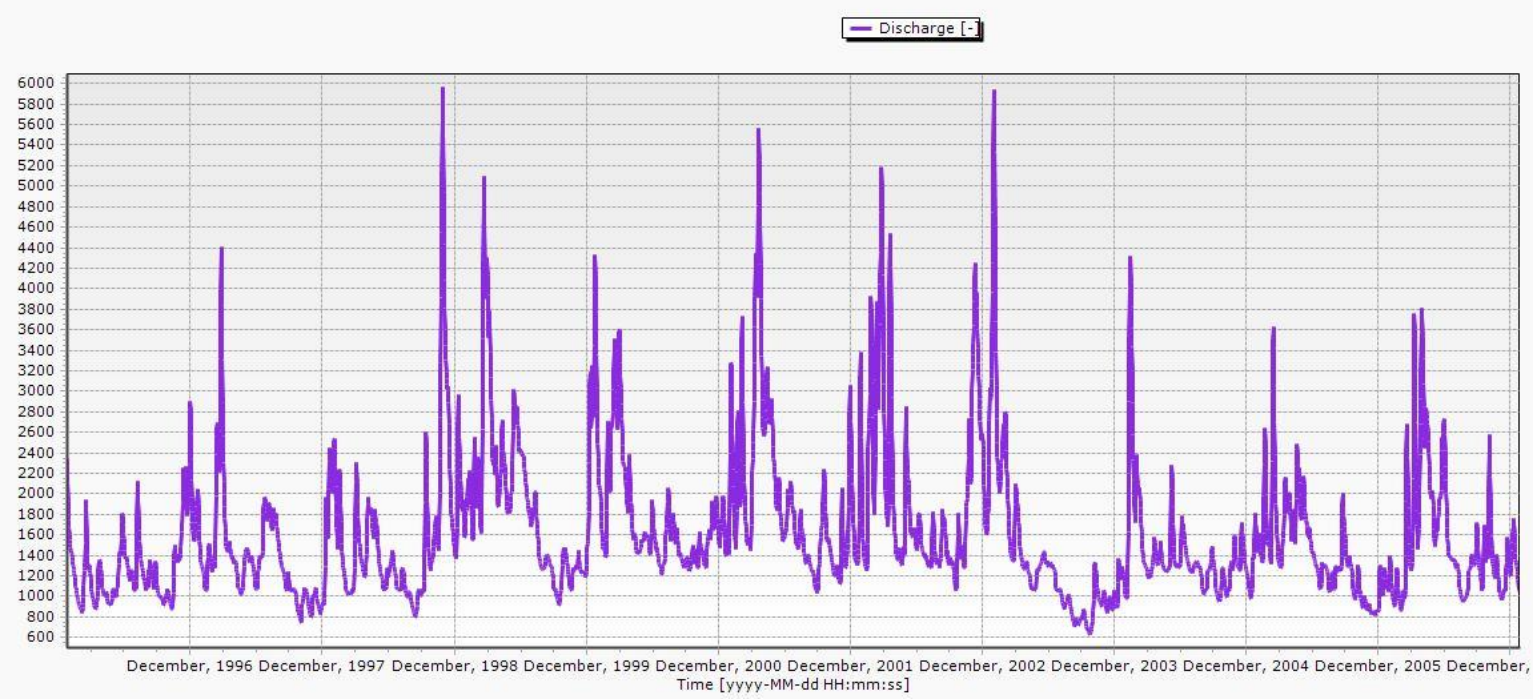

Figuur 9 Afvoerreeks opgelegd op de bovenrand van het model bij Tiel (Waal) voor alle varianten, behalve het klimaatscenario.

Tabel 1 Overzicht van de benodigde randvoorwaarden

\begin{tabular}{lll} 
Randvoorwaarde & Knoopnaam & Type \\
Waal & BovenTiel & Afvoer \\
\hline Maas & BovenLith & Afvoer \\
\hline Lek & Hagestein & Afvoer \\
\hline Maasmond & Maasmond & Waterstand \\
\hline Haringvliet & Haringvliet 10 \& Bokkegat_Buiten & Waterstand \\
\hline Hollandsche IJssel & HollandseIJssel-B & Afvoer \\
\hline Volkeraksluizen & Volkerak-B & Afvoer \\
\hline
\end{tabular}

\subsection{Resultaten}

In deze paragraaf worden de resultaten van het doorrekenen van de 4 varianten met het 1D model besproken. De variant Kierbesluit is niet apart doorgerekend met het 1D model. Er is aangenomen dat de waterstandfluctuaties bij de variant Kierbesluit hetzelfde zijn als bij de variant Huidig beheer. Er wordt gebruik gemaakt van 2 getijparameters binnen deze studie, de getijslag en de middenstand. De waterstand dynamiek in combinatie met de bathymetrie bepaalt het areaal van het intergetijdengebied. Als de getijslag toeneemt, komen er bijvoorbeeld meer laaggelegen plaatsen droog te vallen en overstromen er hooggelegen plaatsen gedurende een korte periode. Het intergetijdengebied neemt dan toe. De middenstand is gedefinieerd als de waterstand die precies 
tussen hoog- en laagwater ligt. Binnen deze analyse is er gekozen om het gemiddelde te bepalen over 2 M2 getijperioden (24 uur en 50 minuten). Dit geeft een goed beeld van de middenstand, omdat zowel de tweemaaldaagse component als de enkeldaagse component in het getij hierdoor wordt uitgemiddeld. Per 10 minuten is het gemiddelde bepaald waardoor er een lopend gemiddelde ontstaat van de middenstand. Een voorbeeld hiervan voor een periode van 2,5 dag is weergegeven in Figuur 10. De getijslag is het verschil tussen de maximum en minimum waterstand over een getijperiode. Ook hier is er voor gekozen om te kijken naar een periode van 24 uur en 50 minuten om de getijslag te bepalen over 2 getijperiodes (Figuur 10).

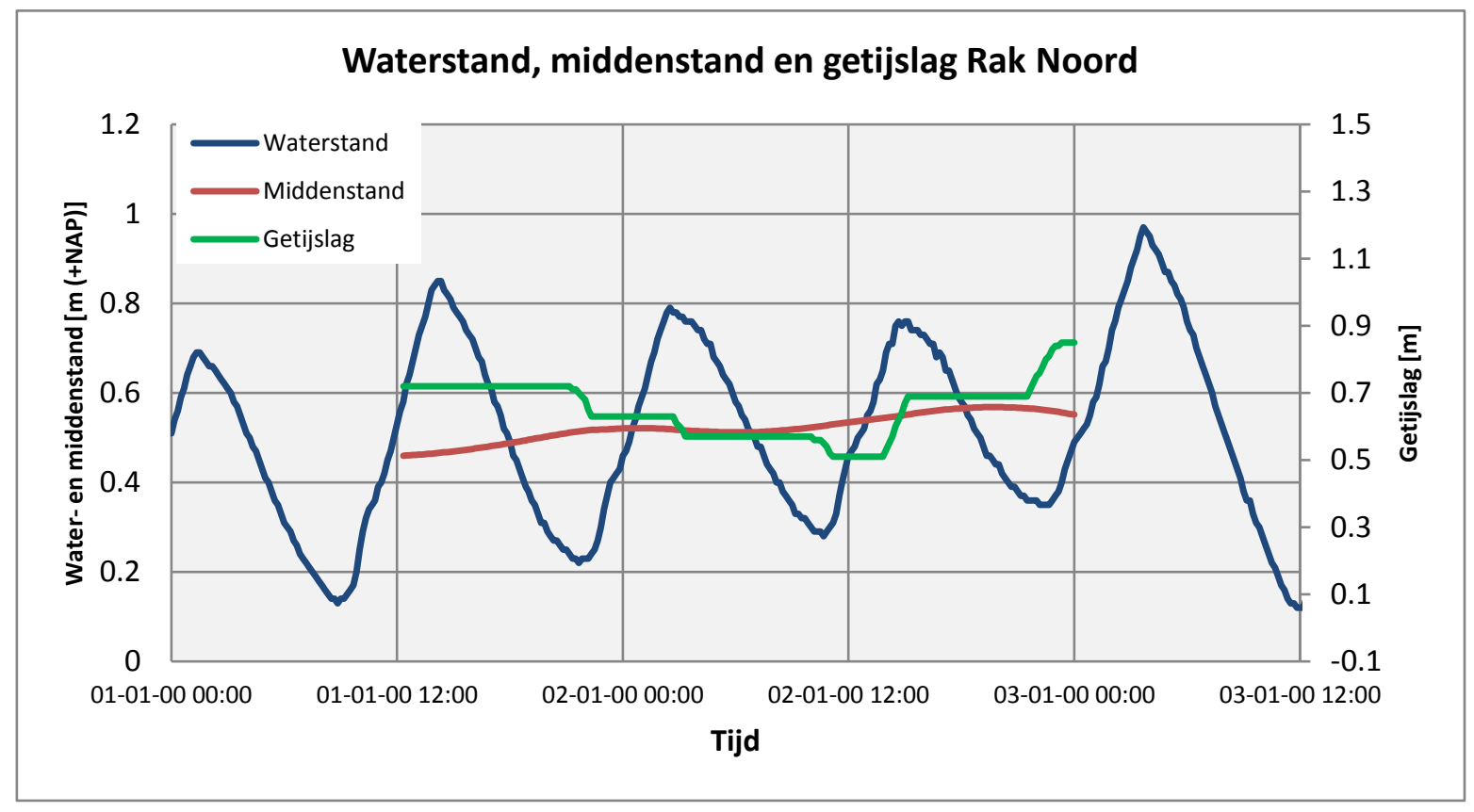

Figuur 10 Voorbeeld van waterstand en getijparameters voor een aantal dagen bij Rak Noord.

\subsubsection{Vergelijking varianten}

Deze studie is bedoeld om een eerste beeld te schetsen van hoeveel intergetijdengebied er terug kan komen in het Haringvliet en omgeving. Er wordt daarom minder nauwlettend gelet op de exacte waarden van de getijparameters maar vooral op de verandering in de getijparameters als gevolg van een andere aansturing van de Haringvlietsluizen. De getijparameters worden met oog op het doel van deze studie over een langere periode gemiddeld, de gemiddelde waarde geeft een beeld van de verandering in getijparameters als gevolg van een andere aansturing van de Haringvlietsluizen. Om het bereik en de variatie binnen de getijparameters weer te geven wordt gebruik gemaakt van cumulatieve frequentieverdelingen van de waterstanden. Om de variatie als gevolg van seizoensfluctuatie weer te geven zijn de getijparameters ook gepresenteerd voor de verschillende kwartalen. De verwachting is namelijk dat tijdens het natte seizoen er een grotere variatie in getijslag kan optreden gecombineerd met een hogere middenstand. Tevens is m.b.t. de ecologische waarde van de intergetijdengebieden van belang om de variatie tijdens het groeiseizoen (voorjaar/zomer) los te kunnen koppelen van de jaarlijkse variatie. Binnen het onderzoeksgebied zijn enkele locaties uitgekozen voor de uitvoer van de resultaten (Figuur 11). Deze resultaten dienen vervolgens als input voor de analyse van het areaal intergetijdengebied. 


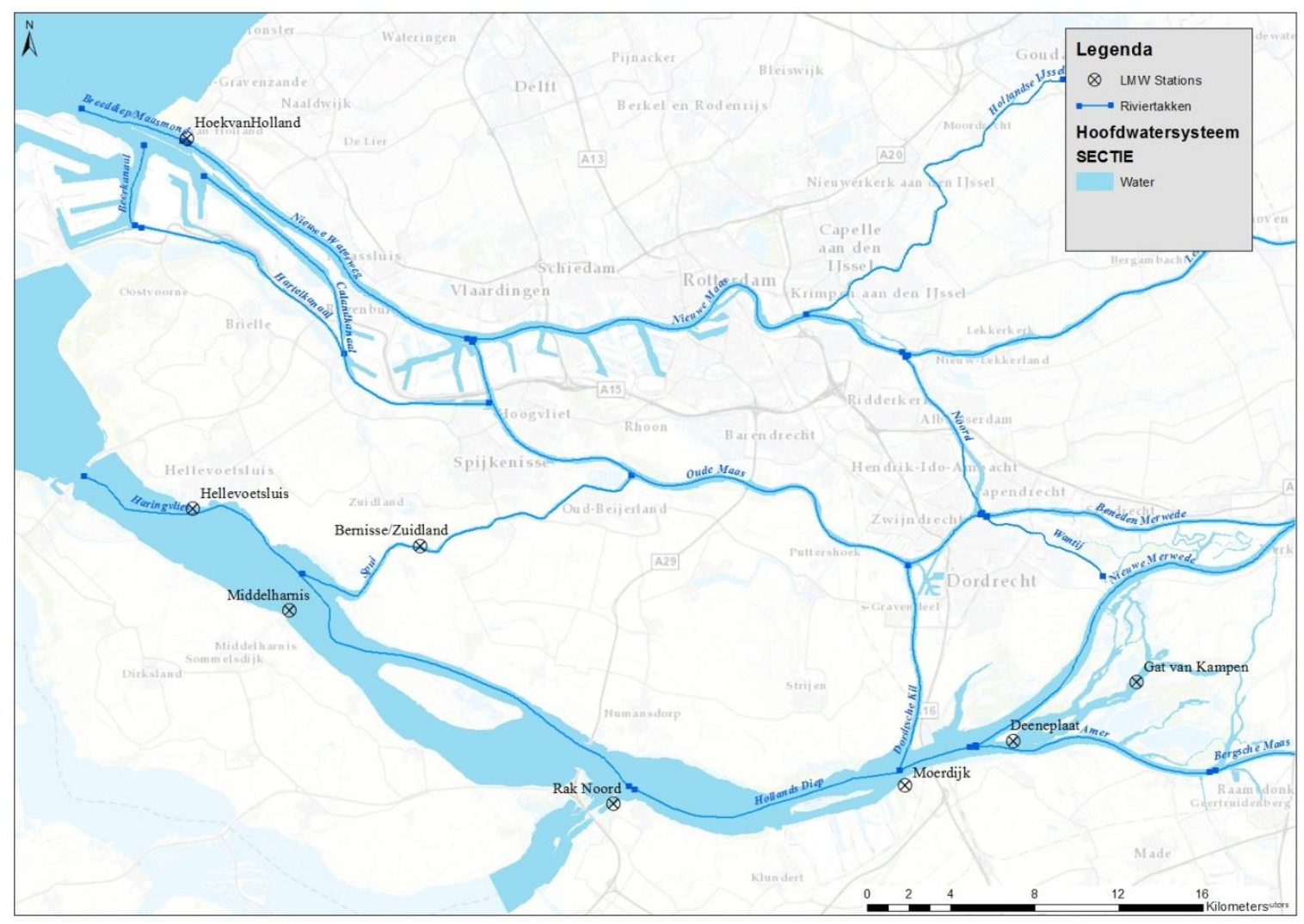

Figuur 11 Overzichtskaart van het onderzoeksgebied met de gebruikte uitvoerstations en Hoek van Holland.

\subsubsection{Huidig beheer: vergelijking berekende resultaten met metingen}

Als aanvang op de studie is er begonnen met een analyse op basis van de gemeten waterstanden om een beter beeld te krijgen van het huidige systeem m.b.t. de relatie tussen de getijdynamiek en het areaal intergetijdengebieden. Daarna zijn voor de periode tussen 2000 en 2005 de modelresultaten vergeleken met de gemeten waterstanden. Deze vergelijking geeft een indicatie van de bruikbaarheid van het model en hoe de referentiesimulatie zich verhoudt met de werkelijkheid.

In Bijlage 1 zijn de gemeten en de door het model berekende getijparameters voor de variant Huidig beheer opgenomen (Tabel 6, Tabel 7, Tabel 8 en Figuur 52 tot en met Figuur 56) Zoals verwacht is er een seizoenvariatie te zien in de middenstand en getijslag (Tabel 6), met hogere waardes in de winter en herfst en lagere waardes in de lente en zomer omdat dan de sluizen vaker gesloten zijn bij lage Rijnafvoer. Daarnaast is te zien dat de getijslag niet veel varieert tussen Hellevoetsluis, Moerdijk en Deeneplaat. Over de gehele lengte van het Haringvliet en Hollands Diep is de getijslag dus min of meer gelijk. De getijslag neemt af met enkele centimeters richting de Biesbosch met het huidige beheer.

De variatie in middenstand en getijslag kan in het gehele gebied groot zijn door windopzet en variërende rivierafvoeren. De totale variatie in de middenstand (maximale minus minimale middenstand) kan oplopen tot 1,70 meter op het Haringvliet/Hollands Diep (Tabel 6).

Echter is in de percentielen van getijparameters te zien dat de extremen in middenstand en getijslag slechts beperkt voorkomen ten opzichte van de gehele reeks (Figuur 52). Het overgrote deel (80$90 \%$ ) van de gemeten middenstand bevindt zich tussen de 0,25 en 0,75 m +NAP. De getijslag bevindt zich ook grotendeels ( $80 \%)$ in het bereik van minder dan 50 centimeter. De variatie in getijslag en middenstand is groter bij Bernisse/Zuidland en Deeneplaat ten opzichte van de stations op het Haringvliet/Hollands Diep. Bij Deeneplaat komen de hogere middenstanden vaker voor, wat waarschijnlijk een gevolg is van de grotere invloed van de rivierenafvoer. Er is iets meer variatie zichtbaar in de getijparameters bij Moerdijk en Rak Noord ten opzichte van Hellevoetsluis. 
De modelresultaten laten grotendeels dezelfde waarden zien ten opzichte van de metingen (Tabel 7). Over het algemeen is de middenstand iets lager in het model ten opzichte van de metingen. Waar de getijslag enkele centimeters groter is in het model dan blijkt uit de metingen (Tabel 8 ) is de variatie in getijslag groter dan in het model (Figuur 52). De verschillen tussen model en meting zijn, voor een nog onbekende reden, het grootst bij Zuidland.

Er zijn wel enkele verklaringen te bedenken voor de afwijkingen tussen het model en de metingen:

- De sluizen gaan sneller verder open dan in de werkelijkheid doordat er geen vertraging is ingebouwd in het model; hierdoor dalen de waterstanden verder in het model en wordt het getijinvloed op het Haringvliet groter dan in werkelijkheid;

- Lokale opstuwing door wind is niet meegenomen in het model, hierdoor worden de absolute maxima niet gesimuleerd in het model;

- Verruimende maatregelen in het hoofdwatersysteem die wel in het model zijn opgenomen (bijvoorbeeld Noordwaard), zijn na 2005 uitgevoerd, hierdoor kan de waterstand dalen in een groot deel van het gebied;

$\mathrm{Er}$ is een verkennende analyse uitgevoerd naar de getijparameters (Middenstand en Getijslag) op de geselecteerde locaties in het onderzoeksgebied. Daarvoor is gebruik gemaakt van scatterplots (Figuur 53 en Figuur 55) om mogelijke verbanden te tonen tussen de getijparameters in het onderzoekgebied en (1) de afvoer in Lobith en (2) de getijparameters in Hoek van Holland. Daarnaast zijn de tijdreeksen (2010 - 2016) voor de getijparameters in het onderzoeksgebied en voor de afvoer in Lobith onder elkaar weergegeven (Figuur 56) om eventuele fasering tussen de variabelen te kunnen duiden.

Uit Figuur 53 en Figuur 54 is af te leiden dat de afvoer in Lobith slechts een geringe invloed heeft op de middenstand en getijslag in het onderzoeksgebied. De invloed van de afvoer op de getijslag is iets groter dan op de middenstand. In Figuur 54 en Figuur 56 is te zien dat lang niet elke piek in middenstand en getijslag is te koppelen aan verhoogde afvoer. Ook leidt niet elke piek in de afvoer tot pieken in middenstand en getijslag. Uit Figuur 53 en Figuur 55 blijkt dat de middenstand in het Haringvliet sterk afhankelijk is van de middenstand bij Hoek van Holland. De invloed van de getijslag bij Hoek van Holland op de getijslag in het Haringvliet is een stuk kleiner.

\subsubsection{Samenvatting resultaten referentiesituatie (Huidig beheer).}

De mediane getijslag in het model ligt tussen de 50 en 65 centimeter (Figuur 12), wat hoger is dan de gemeten waarden (tussen de 35 en $50 \mathrm{~cm}$ ). De mediane middenstand bevindt zich tussen de 0,40 en $0,50 \mathrm{~m}+\mathrm{NAP}$ in het onderzoeksgebied en varieert ruwweg tussen 0,25 en 0,75 m +NAP gedurende $80 \%$ van de tijd. Het model onderschat de middenstand gemiddeld per locatie met hoogstens $5 \mathrm{~cm}$. Ondanks de verschillen tussen de metingen en het model bieden de modelresultaten een bruikbare referentiesituatie voor een verkennende analyse van de varianten. 


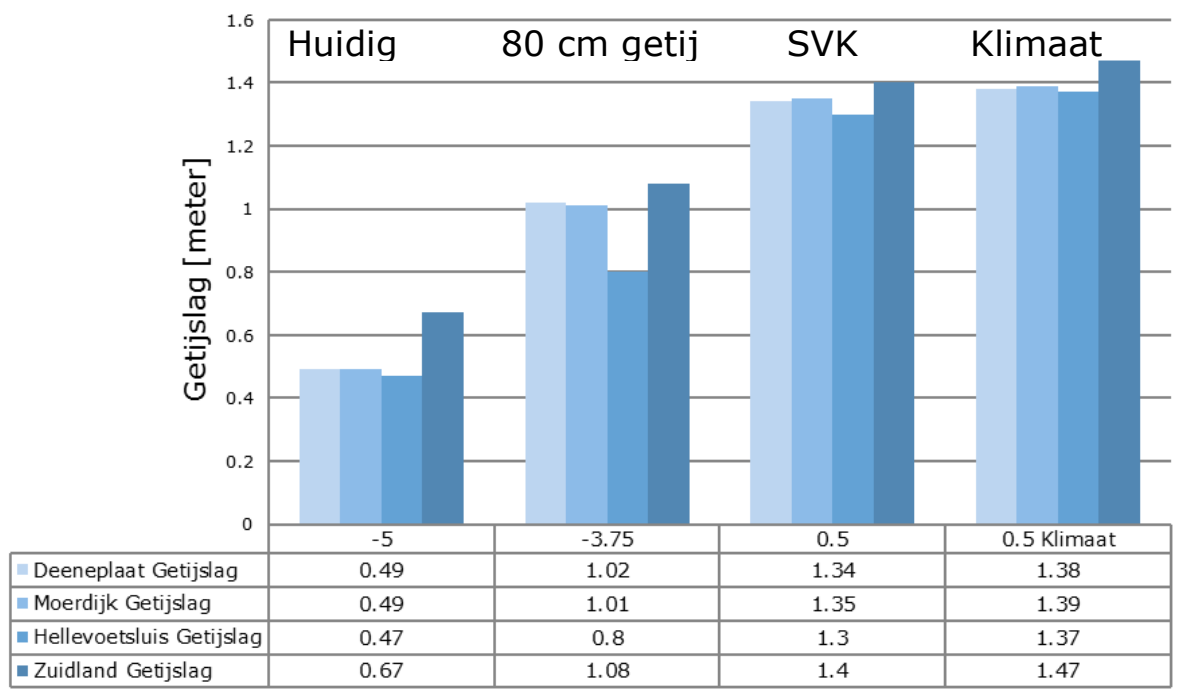

Lower gate edge [m +NAP, -5 is gesloten, 0,5 is volledig open]

Middenstand voor verschillende stations met verschillende openingen van de HVSL

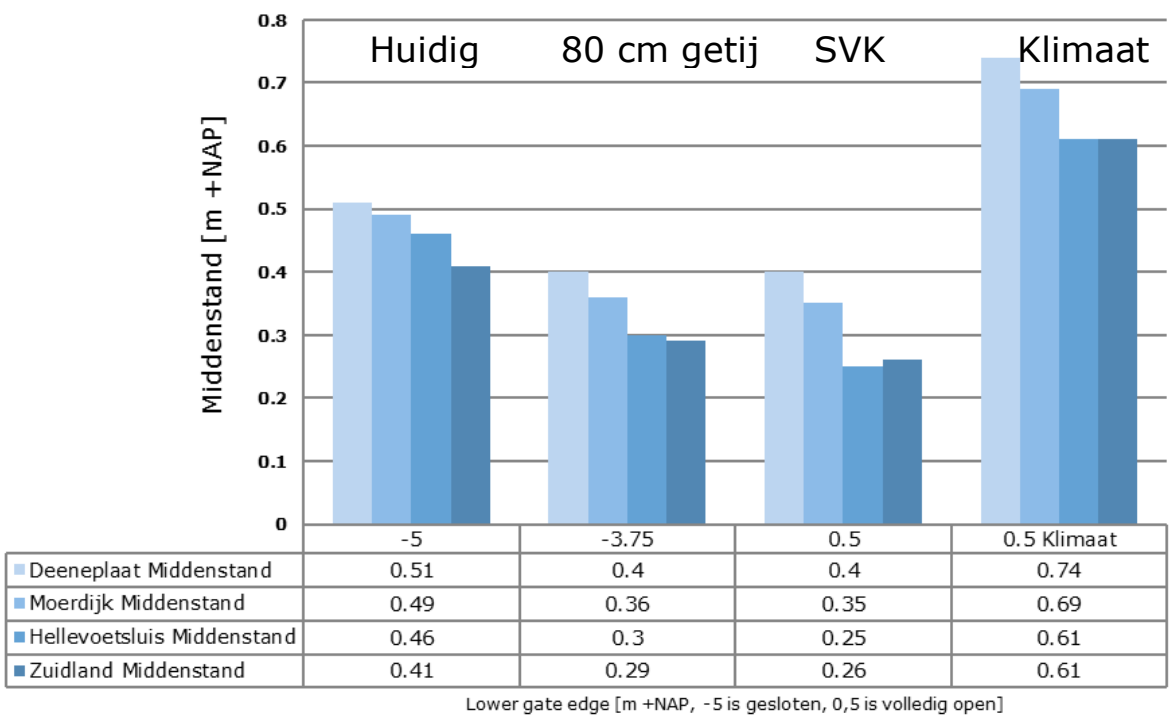

Figuur 12 Verandering in getijparameters voor de varianten Huidig beheer, $80 \mathrm{~cm}$ getij, Stormvloedkering (SVK) en Klimaatscenario als functie van de mate van openen van de Haringvlietsluizen.

Getoond zijn de mediane waarden. Voor de cumulatieve verdeling wordt verwezen naar Bijlage 1 tot en met Bijlage 4.

\subsubsection{Variant $80 \mathrm{~cm}$ getij}

In Bijlage 2 zijn de gemeten en de door het model berekende getijparameters voor de variant $80 \mathrm{~cm}$ getij opgenomen (Tabel 9 en Tabel 10 en Figuur 57). In deze variant, waarin gewerkt is met een vaste opening van de sluizen, neemt de mediane getijslag met 30 tot 50 centimeter toe in het onderzoeksgebied ten opzichte van het huidige beheer (Tabel 9). De mediane middenstand daalt met meer dan 10 centimeter maar is 5 centimeter hoger dan in de stormvloedkering variant (Tabel 10).

Opvallend is dat er een grotere variatie in gemiddelde waarden van de getijparameters zichtbaar is binnen het onderzoeksgebied ten opzichte van de variant Stormvloedkering en Klimaatscenario (Figuur 12, Bijlage 3). Bij Hellevoetsluis is de getijslag 80 centimeter terwijl bij Moerdijk en Deeneplaat een gemiddelde getijslag van rond de 100 centimeter wordt gesimuleerd (Tabel 9). Dit verschil in toename als gevolg van het deels openen van de sluizen komt doordat het getij wordt opgeslingerd op het Haringvliet en Hollands Diep. Bij Hellevoetsluis is de toename in getijslag lineair afhankelijk van de opening van de sluizen. Dit is goed zichtbaar in Figuur 11. Voor de middenstand 
geldt dat bij een geringe opening van de sluizen de middenstand sterk daalt. Uitgaande van een continue opening en geen actief sluisbeheer, vlakt de daling in middenstand af bij het verder openen van de sluizen (Figuur 12).

\subsubsection{Variant Stormvloedkering}

In Bijlage 3 zijn de gemeten en de door het model berekende getijparameters voor de variant Stormvloedkering opgenomen (Tabel 11, Tabel 12 en Figuur 58). De mediane middenstand daalt en de mediane getijslag neemt toe tot meer dan 1,30 meter in deze variant ten opzichte van het huidige beheer (Tabel 11). De mediane middenstand daalt met 10 centimeter bij de Biesbosch en met 20 centimeter bij Hellevoetsluis, het verhang over het Haringvliet neemt dus toe. De mediane getijslag neemt met ongeveer 80 centimeter toe in het Haringvliet, Hollands Diep en de Biesbosch (Tabel 12). De variatie in middenstand en getijslag neemt ook toe in de variant Stormvloedkering ten opzichte van de variant Huidig beheer (zie Figuur 58 en Figuur 12).

De toename in getijslag als gevolg van het openzetten van de sluizen ligt in de lijn der verwachtingen. De absolute waarden zijn vergelijkbaar met de uitkomsten van de MER-studie over het Kierbesluit (MER, Beheer Haringvlietsluizen, 1998). De lagere mediane middenstand in het model ten opzichte van de mediane middenstand uit de MER-studie is vergelijkbaar met de lagere middenstand ten opzichte van de gemeten waarden. De maximale middenstand kan in het model onderschat worden door het ontbreken van het lokale opstuwende effect van de wind op het Haringvliet en Hollands Diep. De toename in variatie in getijslag is een direct gevolg van het niet stuwen van de waterstanden bij lage afvoer en het niet sluiten van sluizen tijdens de vloed.

\subsubsection{Variant Klimaatscenario}

In Bijlage 4 zijn de gemeten en de door het model berekende getijparameters voor variant Klimaatscenario opgenomen (Tabel 13, Tabel 14 en Figuur 59). De mediane middenstand neemt logischerwijs toe ten opzichte van de variant Stormvloedkering als gevolg van de zeespiegelstijging (Tabel 13). De mediane getijslag neemt ook iets toe ten opzichte van de variant Stormvloedkering door de grotere variatie in afvoer (Tabel 14, Figuur 59). De verschillen in mediane getijslag zijn echter zeer klein. Echter is de toename in mediane middenstand, uitgaande van geen verdere aanpassing in het systeem, cruciaal voor het areaal van het intergetijdengebied. Gebieden die nu af en toe nat worden, zullen met zeespiegelstijging continu onder invloed staan van het getij.

\subsection{Conclusies hydrodynamische modellering}

Met een 1D model zijn vier varianten doorgerekend voor een periode van 10 jaar om een breed bereik aan mogelijke condities door te rekenen. Deze vier varianten geven een beeld van de invloed van een aanpassing in de aansturing van de Haringvlietsluizen en de verwachte invloed van klimaatverandering. Door het doorrekenen van 10 jaar met een grote verscheidenheid aan randvoorwaarden geven de resultaten een redelijk compleet beeld van de mogelijke variatie in het systeem.

Het 1D model geeft tussen 2000 en 2005, ondanks de vereenvoudigde aansturing van de Haringvlietsluizen in het model, vergelijkbare resultaten ten opzichte van de metingen. In de huidige situatie is de getijslag ongeveer 40 centimeter op het Haringvliet. Er is amper sprake van variatie in zowel middenstand als getijslag langs het Haringvliet en in variatie met de tijd door de opstuwende werking van de Haringvlietsluizen.

Met het aansturen van de Haringvlietsluizen als een stormvloedkering neemt de getijslag met 80 centimeter toe ten opzichte van de variant Huidig beheer. De mediane middenstand daalt over het gehele Haringvliet, maar sterker bij Hellevoetsluis. Het verhang neemt dus ook toe op het Haringvliet. De variatie in getijslag en middenstand neemt ook toe ten opzichte van de variant Huidig beheer. Met het deels openen van de Haringvlietsluizen (80-centimeter getij variant) zal de getijslag sterker toenemen op het Hollands Diep in vergelijking met het Haringvliet. Met deze variant, waarbij de 
schuifopening $1,75 \mathrm{~m}$ is, neemt de getijslag met 40 centimeter toe bij Hellevoetsluis en met 60 centimeter toe op het Hollands Diep en de Biesbosch.

Als gevolg van klimaatverandering stijgt de zeespiegel en is de variatie in afvoer groter. Dit leidt op het Haringvliet tot een toename in middenstand van ongeveer 40 centimeter (Klimaatscenario 2050 Warm). De getijslag zal een klein beetje toenemen door de grotere variatie in afvoer.

\subsection{Inschatting zoutindringing bij ander beheer Haringvlietsluizen}

\subsubsection{Achtergrond}

Op het Haringvliet spelen een aantal complexe processen een belangrijke rol ten aanzien van de zoutindringing, zoals beschreven hieronder:

- In het Haringvliet bevinden zich een aantal diepe getijgeulen. Vanwege de lage stroomsnelheden kan hier zoutwater dat over de bodem naar binnen is gedrongen langere tijd verblijven en onder invloed van wind of verandering in stroomsnelheden op een later moment mogelijk weer uitspoelen;

- De geometrie van de sluizen (zie Figuur 6) en detailstroming die hierin optreedt, is bepalend voor de hoeveelheid zoutwater die er naar binnen en naar buiten wordt gebracht;

- Het zoutgehalte in de Voordelta is bepalend voor hoeveel zout er naar binnen kan worden gelaten tijdens vloed. Dit zoutgehalte wordt sterk beïnvloedt door de kuststroming welke het zoetere rivierwater uit de Maasmonding met zich meevoert.

Het verkrijgen van inzicht in deze processen vereisen een 3D modellering, met enerzijds een hoge resolutie om de detailstroming voldoende goed te kunnen weergeven en anderzijds een groot modelbereik, zodat de kuststroming wordt omvat. Momenteel wordt er gewerkt aan een 3D model die geschikt is voor de modellering van de zoutindringing op het Haringvliet (Thiessen et al., 2017).

Omdat er ten tijde van de MER-studie twijfels bestonden over de uitkomsten van de zoutberekeningen met toenmalige 1D- en 3D modellen, is ervoor gekozen het Kierbesluit in te voeren middels het "Lerend Implementeren" principe. Dit houdt in dat terwijl naar het nieuwe stuurprogramma toegewerkt wordt de zoutconcentraties gemonitord zullen worden. De zoutindringing mag hierbij niet verder komen dan de lijn Spui-Middelharnis. De opening van de sluizen zal hierop aangepast worden. Het kan dus zijn dat bij het uiteindelijke stuurprogramma de vloedopening van de sluizen kleiner of groter zal zijn dan beschreven in het kandidaat stuurprogramma voor de Kier.

Omdat het voor de ecologie noodzakelijk is om een goede schatting van de zoutindringing te krijgen wat, met de huidige modellen, (nog) niet mogelijk is, werd in dit onderzoek gekozen voor een deskundigenoordeel, ondersteund met metingen uit de periode kort voor de sluiting van het Haringvliet. Hieronder volgen de schattingen voor de vier varianten beschouwd in dit onderzoek: variant Kierbesluit, variant $80 \mathrm{~cm}$ getij, variant Stormvloedkering en variant Klimaatscenario. De gelaagdheid (zoet-zout stratificatie) is echter hierin niet meegenomen, terwijl dit met name voor de Kier-variant een aandachtspunt is. Door de overwegend lage stroomsnelheden in deze variant kan gelaagdheid optreden waarmee zoutwater in de diepe geulen kan blijven steken. Zo kunnen mogelijk op bepaalde locaties zoute onderlagen ontstaan terwijl de bovenlaag relatief zoet is. Ook kan het zijn dat zoutwater uit de diepe geulen door opwaaiing of verandering in stroomsnelheden ineens gaat verspreiden en zo waterlagen of gebieden die meestal zoet zijn tijdelijk doen verzilten. Dit heeft mogelijk gevolgen voor de ecologie. Ook voor de variant $80 \mathrm{~cm}$ getij en variant Stormvloedkering variant geldt dit aandachtspunt, zij het in mindere mate dan voor de variant Kierbesluit. Vanwege de onzekerheid van de ligging van de zoutgrens voor de varianten $80 \mathrm{~cm}$ getij, Stormvloedkering en Klimaatscenario is er een bandbreedte aangegeven.

Omdat de schatting voor de variant $80 \mathrm{~cm}$ getij is afgeleid uit de variant Kierbesluit en de variant Stormvloedkering, worden deze eerst besproken. 


\subsubsection{Zoutindringing bij de variant Kierbesluit}

Zoals beschreven is de afspraak bij het Kierbesluit dat de zoutindringing niet verder mag komen dan de lijn Spui-Middelharnis. Het uiteindelijke stuurprogramma zal hier dus op worden afgesteld. Hiermee is vastgelegd waar de $300 \mathrm{mg} \mathrm{Cl} \mathrm{l}^{-1}$ grens (maximaal) komt te liggen, zie Figuur 13. Deze chloride concentratie, die overeenkomt met een saliniteit van 0,5 ppt, ligt op de bovengrens van zoet water (bij een hogere concentratie spreekt men van "licht brak"water) (L\&O, 1958). Voor de inname van zoetwater bij Bernisse wordt een grenswaarde van $150 \mathrm{mg} \mathrm{Cl} \mathrm{l}^{-1}$ gehanteerd (Van Leeuwen et al., 2004).

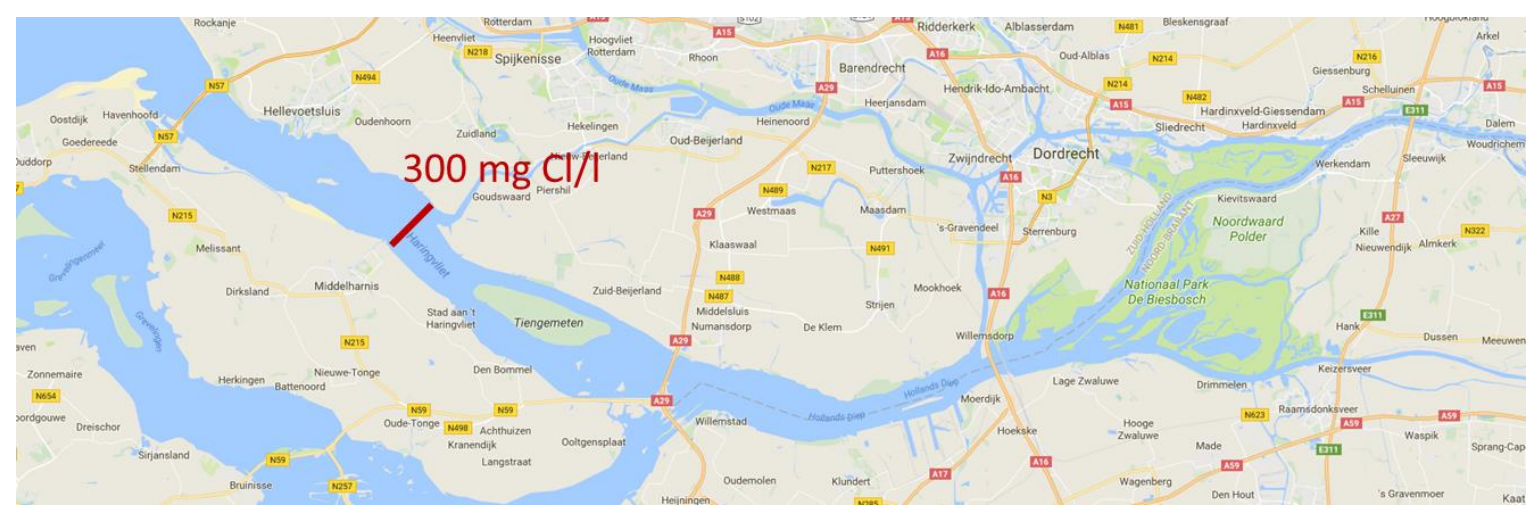

Figuur 13 Deskundigen inschatting van de ligging van de zoutgrens van $\sim 300 \mathrm{mg} \mathrm{Cl} \mathrm{l}^{-1}$ bij de variant Kierbesluit.

\subsubsection{Zoutindringing bij de variant Stormvloedkering}

Om een indicatie te krijgen van de mogelijke zoutindringing bij de variant Stormvloedkering is gekeken naar metingen van eind jaren '60, zoals gepresenteerd in de MER rapportage (Rijkswaterstaat, 1998d; b), zie Figuur 14.

In deze periode was de constructie van de dam al gedeeltelijk tot grotendeels aanwezig. Daarmee is de situatie enigszins vergelijkbaar met de variant Stormvloedkering. Een aantal veranderingen hebben sindsdien plaatsgevonden die de zoutindringing in het Haringvliet hebben beïnvloedt. Ten eerste zijn de Haringvlietdam en sluizen verder voltooid. Ten tweede kan er sinds de afsluiting van het Volkerak met de Volkerakdam in 1969 geen zoutwater meer het gebied binnenkomen vanuit de Oosterschelde via het Volkerak. Tot slot is sinds 1970 het Rotterdamse Havengebied aanzienlijk uitgebreid, waardoor de kuststroming van "zoet" rivierwater is veranderd. Dit heeft mogelijk invloed gehad op het zoutgehalte in de buitendelta. De verwachting is dat de zoutindringing bij de variant Stromvloedkering minder zal zijn dan in de situatie van eind jaren '60 toen deze grens ten oosten van Willemstad lag (Figuur 14). De $300 \mathrm{mg} \mathrm{l}^{-1}$ grenzen bij de variant Stormvloedkering zullen daarom afwijken van de situatie van eind jaren '60 zoals weergegeven in Figuur 14.

Een schatting voor de mate van zoutindringing bij de stormvloedkering variant is weergegeven in Figuur 15, voor gemiddelde en lage rivierafvoer. Ook hierbij zijn de grenzen met een kleurverloop aangegeven om de onzekerheid van de schatting weer te geven. 


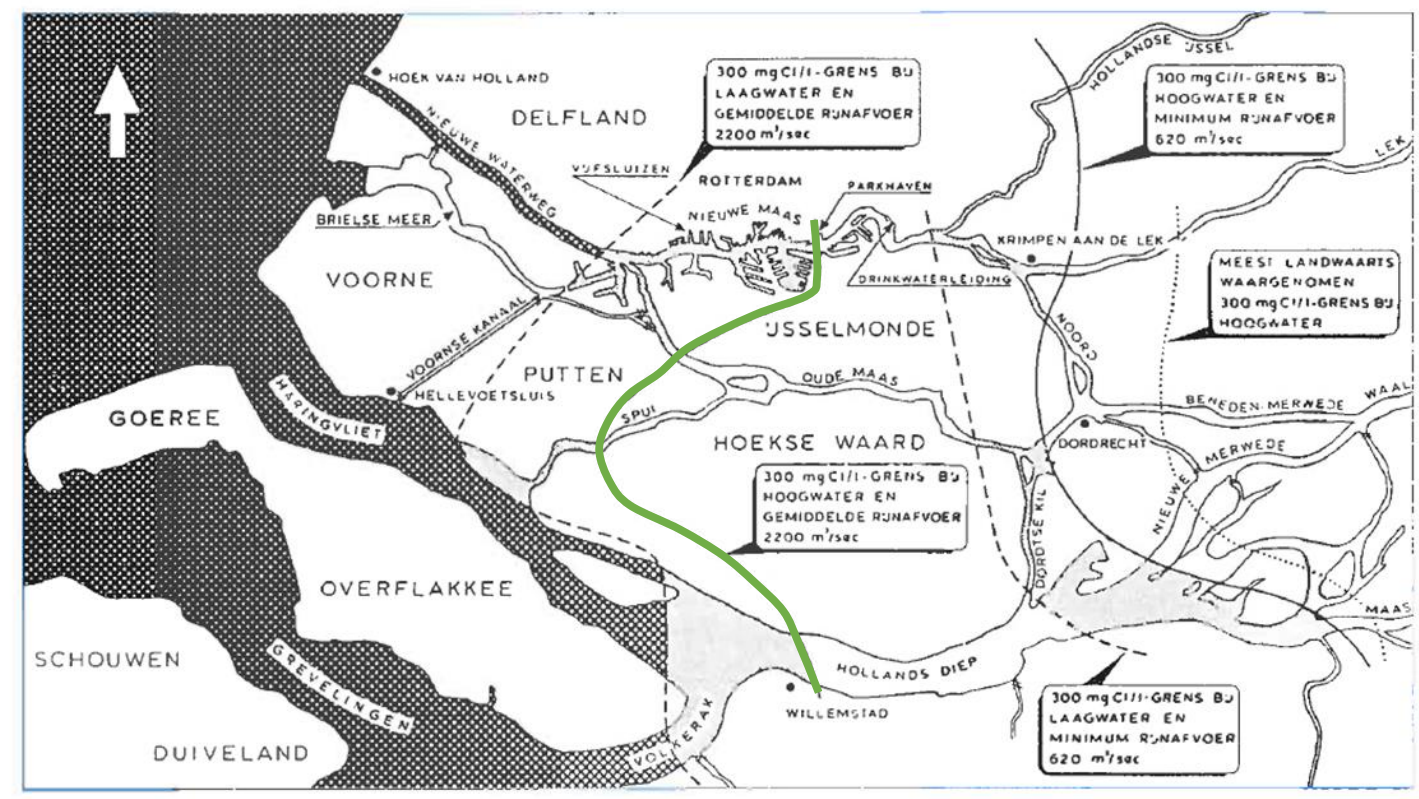

Figuur 14 Globaal overzicht van de $300 \mathrm{mg} \mathrm{Cl} \mathrm{l}^{-1}$ grenzen, gebaseerd op metingen aan het wateroppervlakte uit eind jaren 60 . De $300 \mathrm{mg} \mathrm{Cl} \mathrm{I}^{-1}$ isocline bij hoogwater en gemiddelde Rijnafvoer is in het oranje aangegeven. Bron: Rijkswaterstaat (1998b).

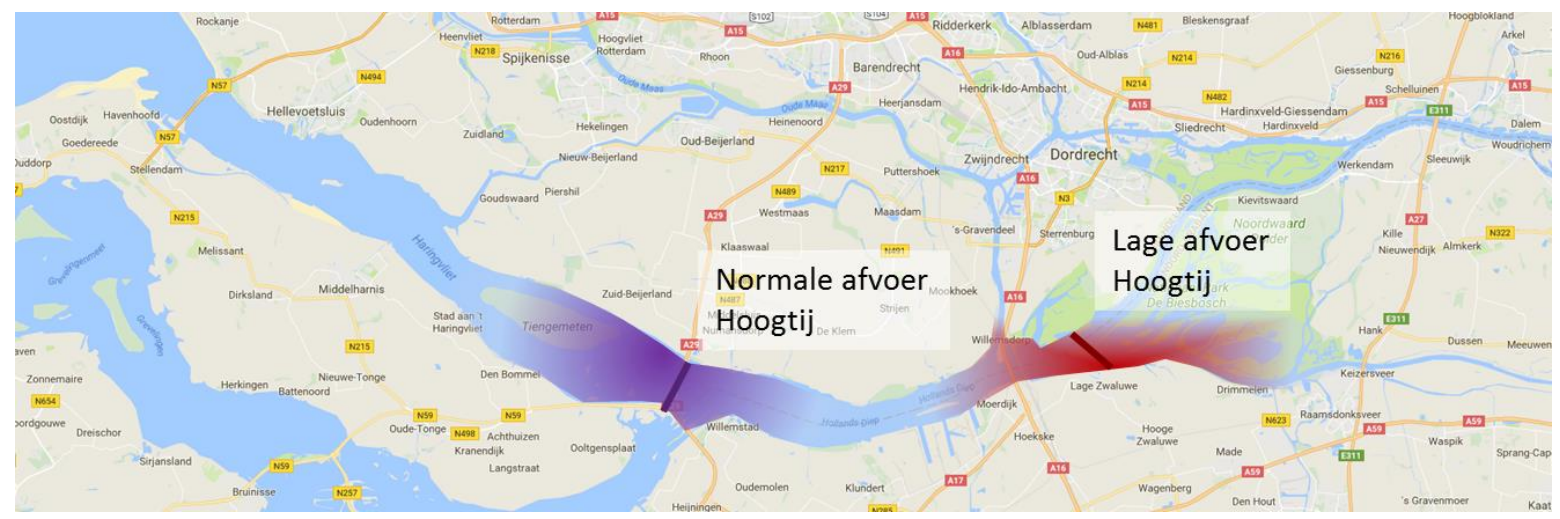

Figuur 15 Deskundigen inschatting van de ligging van de zoutgrenzen van $\sim 300 \mathrm{mg} \mathrm{Cl} \mathrm{l}^{-1}$ bij de variant Stormvloedkering voor normale afvoer (paars) en lage afvoer (rood). Het kleurverloop is een weergave van de bandbreedte waar de grens zou kunnen komen te liggen en geeft de grote mate van onzekerheid weer. Ten behoeve van de ecotopenmodellering (Hoofdstuk 6). Voor de duidelijkheid is het meest donkere deel van dit bereik (hoogste waarschijnlijkheid) aangeduid met een donkere streep.

\subsubsection{Zoutindringing bij variant $80 \mathrm{~cm}$ getij}

Vermoedelijk zal de mate van zoutindringing tussen de variant Kierbesluit en de variant Stormvloedkering inliggen, zie Figuur 16. Omdat er voor deze variant geen afspraken, historische metingen of betrouwbare berekeningen voorhanden zijn, is er een flinke onzekerheid in waar de grens zal komen te liggen. Dit is weergegeven in het figuur middels een kleurverloop. Ten behoeve van de ecotopenmodellering in Hoofdstuk 6 is het meest donkere deel van dit bereik (hoogste waarschijnlijkheid) aangeduid met een donkere streep. Onder invloed van de sterk variërende rivierafvoer zal de ligging van de zoutgrens van $300 \mathrm{mg} \mathrm{Cl} \mathrm{l}^{-1}$ ook variëren. Dit betekent dat bepaalde gebieden maandenlang achter elkaar afwisselend onder invloed van zoet- en zoutwater kunnen zijn zoals ook in een natuurlijk estuarium voorkomt. 


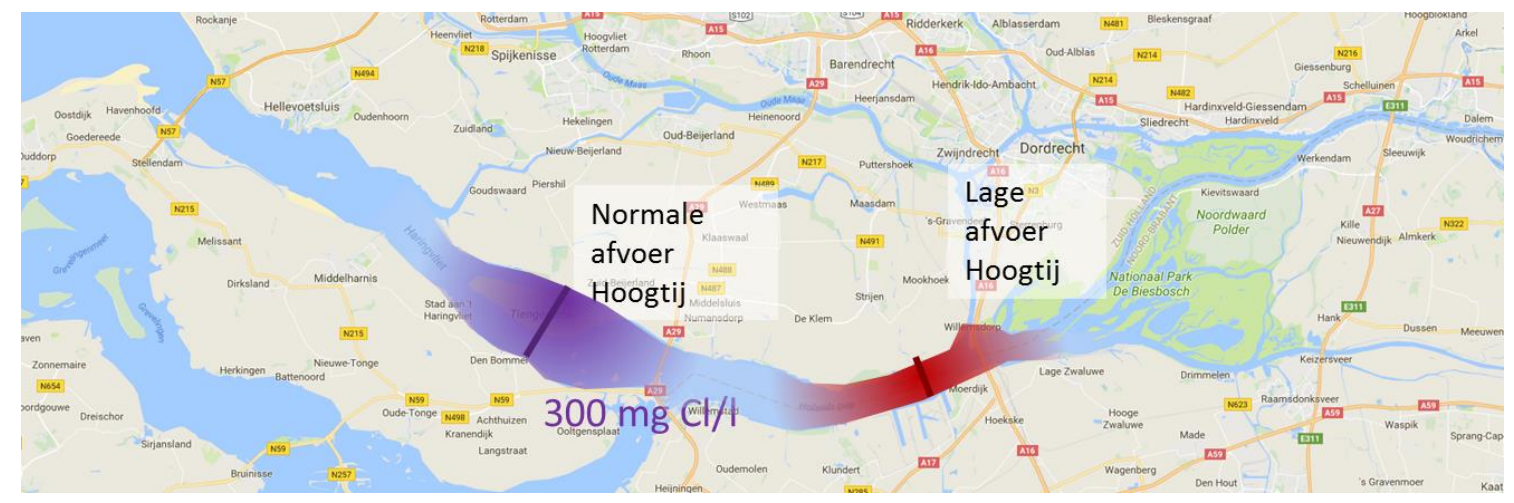

Figuur 16 Deskundigen inschatting van de ligging van de zoutgrenzen van $\sim 300 \mathrm{mg} \mathrm{Cl} \mathrm{l}^{-1}$ bij de variant 80 $\mathrm{cm}$ getij voor normale afvoer (paars) en lage afvoer (rood). Het kleurverloop is een weergave van de bandbreedte waar de grens zou kunnen komen te liggen en geeft de grote mate van onzekerheid weer. Ten behoeve van de ecotopenmodellering (Hoofdstuk 6). Voor de duidelijkheid is het meest donkere deel van dit bereik (hoogste waarschijnlijkheid) aangeduid met een donkere streep.

\subsubsection{Zoutindringing bij de variant Klimaatverandering}

Ten gevolge van klimaatverandering wordt verwacht dat de zeespiegel zal stijgen en dat de rivierafvoeren extremer zullen worden. Zowel de zeespiegelstijging en lagere rivierafvoeren zullen ervoor zorgen dat zout verder kan indringen. Hoever de zoutindringing zou kunnen komen onder een dergelijk scenario is zonder ondersteunende modelsimulaties niet te voorspellen. Om voor de ecotopenmodellering toch enig houvast te bieden, is een zeer ruwe schatting gemaakt van de ligging van de zoutindringing bij de variant Klimaatscenario (Stormvloedkering in combinatie met KNMI 2050 Warm scenario klimaatveranderingen). Het resultaat is weergegeven in Figuur 17. De onzekerheidsband in het kleurverloop is groter dan bij de vorige schattingen. Tevens benadrukt het vraagteken op de figuur de grote onzekerheid rondom deze schatting.

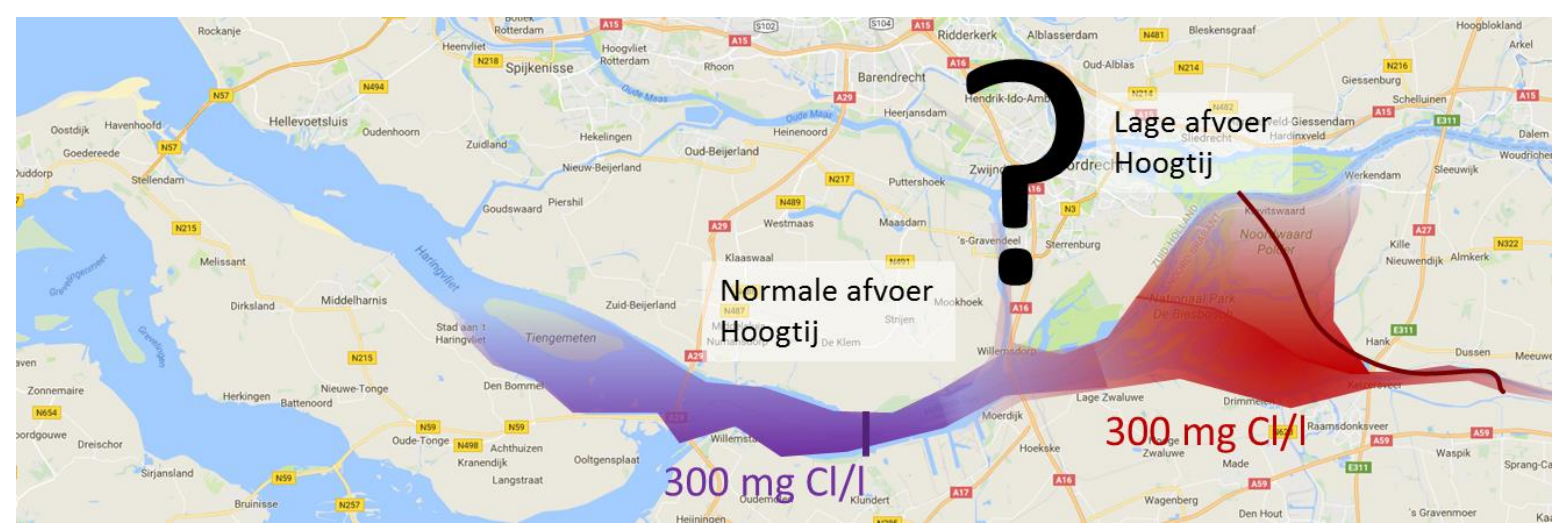

Figuur 17 Deskundigen inschatting van de ligging van de zoutgrenzen van $\sim 300 \mathrm{mg} \mathrm{Cl} \mathrm{l}^{-1}$ bij de variant Klimaatverandering (KNMI 2050 Warm scenario) voor normale afvoer (paars) en lage afvoer (rood). Het kleurverloop is een weergave van de bandbreedte waar de grens zou kunnen komen te liggen en geeft de grote mate van onzekerheid weer. Omdat het hier een schatting betreft op basis van zeer weinig informatie, heeft deze schatting een zeer beperkte betrouwbaarheid, zoals weergegeven met het vraagteken. Ten behoeve van de ecotopenmodellering is het meest donkere deel van dit bereik (hoogste waarschijnlijkheid) aangeduid met een donkere streep. 


\section{$5 \quad$ Morfologie}

\section{$5.1 \quad$ Inleiding}

Dit hoofdstuk richt zich op de morfologische onderzoeksvragen ( 3,4 en 5$)$ uit $\S 1.3$. In deze verkennende studie zijn deze vragen beantwoord middels een deskundigenoordeel op basis van een literatuurstudie gecombineerd met uitkomsten van de hydrodynamische berekeningen. Varianten die hierbij aan bod komen zijn Stormvloedkering en de variant $80 \mathrm{~cm}$ getij (zie hoofdstuk 3).

\subsection{Mogelijkheden herstel plaat-geul dynamiek}

\subsubsection{Zandhonger, plaat-geul dynamiek en oevererosie}

Voor natuurlijke estuaria geldt dat er een relatie is tussen het doorstroomoppervlak en het getijvolume. Voor een morfologisch evenwicht geldt, hoe groter het getijvolume, hoe groter het doorstroomoppervlak. Wanneer het getijvolume toeneemt, zal het gebied streven naar een groter doorstroomoppervlak en erosie optreden. Wanneer het getijvolume afneemt, zal het gebied willen aanzanden. Dit laatste wordt zandhonger genoemd.

"Normaal" systeem

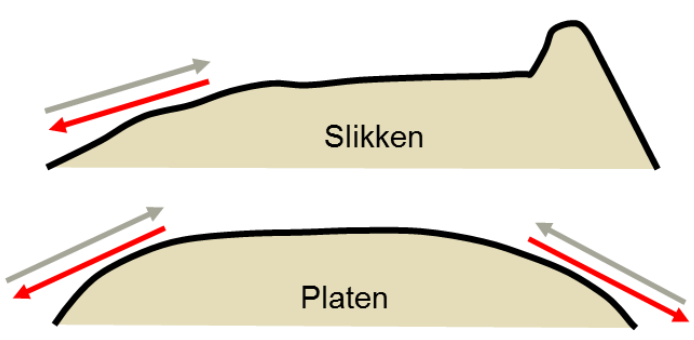

Systeem met verminderde getijwerking

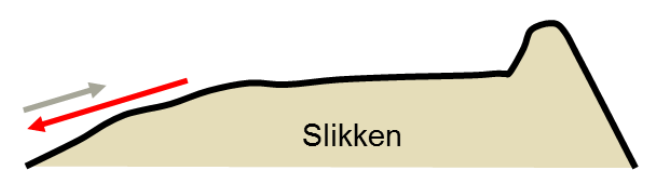

Platen

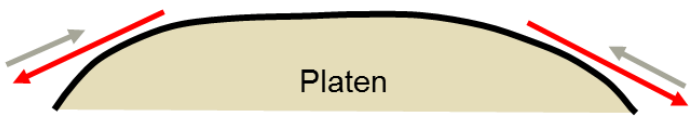

Opbouwende krachten, getijstromen

Erosieve krachten, golven (+getij +wind- \& golfgedreven stroming)

Figuur 18 Illustratie morfodynamiek van platen en slikken.

Op basis van metingen van diverse estuaria heeft O'Brien (1969) de volgende relatie opgesteld:

$$
A=9.015 \cdot 10^{-4} P^{0.85}
$$

Waarbij A het doorstroomoppervlak is in $\left[\mathrm{m}^{2}\right]$ en $\mathrm{P}$ het getijvolume in $\left[\mathrm{m}^{3}\right]$. Een verandering in getijdynamiek heeft ook gevolgen voor de plaat-geul dynamiek, de dynamiek waarbij geulen zich verleggen en platen en slikken opbouwen en verplaatsen. Voor de natuurlijke plaatopbouw zijn twee componenten van belang, de opbouwende werking van de getijstroming en de erosieve werking van golven, zie illustratie in Figuur 18. Wanneer de getijstroming afneemt, is er onvoldoende kracht om sediment uit de geulen op de platen te stuwen en zal erosie van platen en slikken optreden.

Illustratief voor de opbouwende werking van de getijstroming zijn ontwikkelingen in de Oosterschelde en de Westerschelde. In de Oosterschelde is door de bouw van de stormvloedkering de getijstroming afgenomen en nemen de platen nu in hoogte af, zie Figuur 19a. In de Westerschelde is door het verdiepen van de geulen de getijstroming juist toegenomen en nemen de platen toe in hoogte. Huidige snelheden worden getoond in Figuur 19b. Geconcludeerd wordt dat de getijstroming in de 
Oosterschelde onder een kritische waarde is gekomen, terwijl die in de Westerschelde boven deze waarde is gebleven (Wang et al., 2015; De Vet et al., 2017). Op basis van deze gegevens en observaties in andere estuaria, wordt de kritische snelheid voor natuurlijke plaatopbouw rond de $1 \mathrm{~m}$ $\mathrm{s}^{-1}$ geschat.

Tot slot gaat een afname van de getijstroming meestal gepaard met een afname van de getijslag (uitzondering is de Oosterschelde, waar door het afsluiten van bepaalde deelgebieden de getijslag maar in beperkte mate is afgenomen). Bij een afname van de getijslag wordt de golfenergie geconcentreerd op een klein gebied, wat zorgt voor meer oevererosie met steilere hellingen, zie Figuur 18.
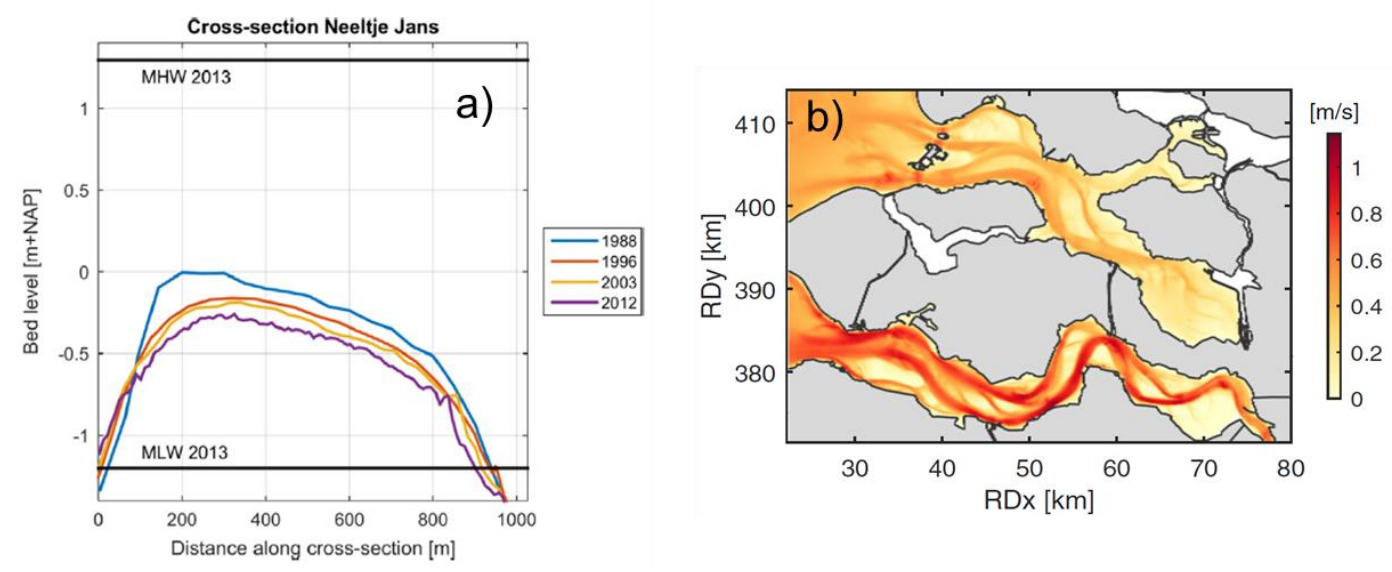

Figuur 19 a. Typische verandering van de platen in de Oosterschelde, zoals geïllustreerd aan de hand van dwarsdoorsneden van de bodemligging voor de plaat bij Neeltje Jans. Bron: Wang et al. (2015). b. huidige gemiddelde snelheden (diepte gemiddeld), met in het noorden de Oosterschelde en in het zuiden de Westerschelde. Bron:De Vet et al. (2017).
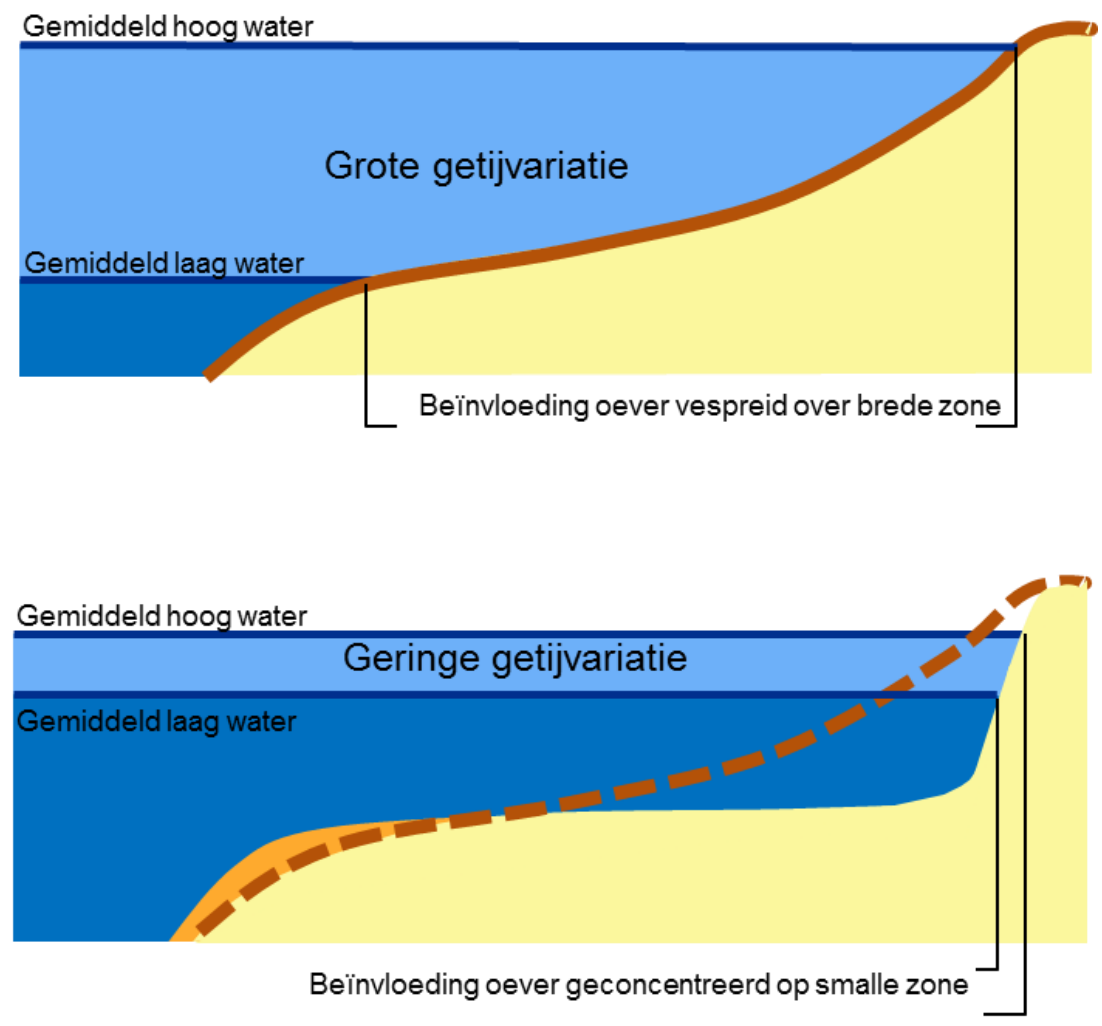

Figuur 20 Illustratie oever- of plaaterosie door invloed van golven over een kleiner verticaal bereik, door vermindering van de getijslag. Ter vergelijking geeft de gestreepte lijn in het onderste figuur het profiel aan van de situatie met grote getijvariatie (bovenste figuur). 


\subsubsection{Haringvliet voor en na sluiting}

Voor de afsluiting van het Haringvliet was de getijslag rond de 1,8 m bij Hellevoetsluis en 2,25 $\mathrm{m}$ bij Moerdijk. Afhankelijk van de rivierafvoer en het getij varieerde de stroomsnelheid grofweg tussen de 1,60 en -1,30 $\mathrm{m} \mathrm{s}^{-1}$ bij Hellevoetsluis en tussen de 0,80 en -0,85 $\mathrm{m} \mathrm{s}^{-1}$ bij Moerdijk (Rijkswaterstaat, 1998d), waarbij een positieve snelheid een zeewaartse richting betekent. Dit was voldoende voor een evenwichtige plaat-geul dynamiek in stand te houden, ook met het verdelen van de golfinvloed over een bereik van ongeveer $2 \mathrm{~m}$. De bodem van het Haringvliet bestond voornamelijk uit zand (Van Maren and Wang, 2009).

Na sluiting is de getijslag afgenomen tot rond de 0,4 $\mathrm{m}$ in het Haringvliet en Hollands Diep en zijn de stroomsnelheden drastisch afgenomen, tot ruim onder de $1 \mathrm{~m} \mathrm{~s}^{-1}$. Door de afname van de getij invloed is het doorstroomoppervlak te ruim geworden voor de hoeveelheid water die erdoorheen stroomt en is er zandhonger ontstaan. Hierdoor heeft er flinke sedimentatie plaatsgevonden in de geulen, waarbij aanvankelijk de sterkste sedimentatie plaatsvond in het oostelijke deel van het Hollands Diep waar de Amer en de Nieuwe Merwede samenkomen (Dir Zuid Holland, 1992), zie Figuur 21. Dit sedimentatiefront verschuift langzaam westwaarts in de tijd. Huidige gemiddelde sedimentatietrends zijn orde 1 à $2 \mathrm{~cm} \mathrm{jaar}^{-1}$ voor het Hollands Diep en 0,2 à $1 \mathrm{~cm} \mathrm{jaar}^{-1}$ voor het Haringvliet (Snippen et al., 2005; Becker, 2015). Geschat wordt dat het systeem nog lang geen evenwicht heeft bereikt (Rijkswaterstaat, 1998c).

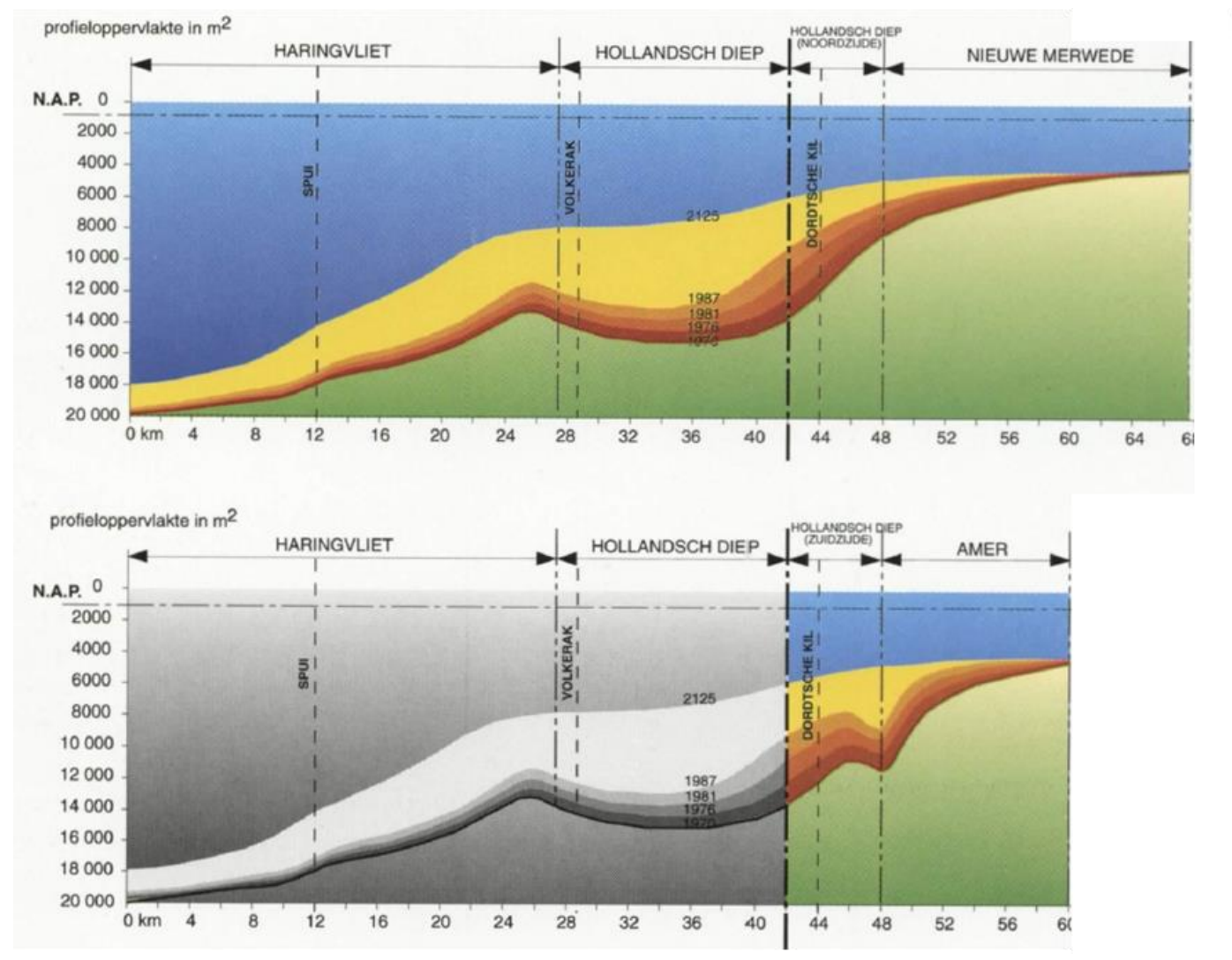

Figuur 21 Geomorfologische ontwikkeling van het bekken aan de hand van de afname het doorstroomoppervlak, voor Nieuwe Merwede - Haringvliet (bovenste figuur) en Amer Haringvliet (onderste figuur), met op de $x$-as het aantal kilometers vanaf de Haringvlietmonding. De bovenkant van het groene gedeelte geeft de evenwichtstoestand weer vlak voor afsluiting. Het bruine gedeelte geeft de waargenomen afname van het doorstroomoppervlak tussen 1970 en 1987. Het gele gedeelte geeft de verwachte ontwikkeling weer tot het jaar 2125. Bron: Dir Zuid Holland (1992).

De mate van sedimentatie varieert sterk in de ruimte. Zo zijn in het oostelijke deel van het Hollands Diep de geulen vrijwel geheel opgevuld en ligt er een 6 tot $8 \mathrm{~m}$ dikke sliblaag (Rijkswaterstaat, 1998c). In het westelijke deel van het Hollands Diep en in het Haringvliet is de sedimentatie in de geulen minder sterk en betreft 1 à 2 m, zie Figuur 22 (Rijkswaterstaat, 1998c; Van Maren and Wang, 
2009). Een deel van de sedimentatie bestaat uit rivierslib, welke tot de jaren ' 80 sterk vervuild was. In de opvolgende jaren zijn deze lagen bedekt met schoner sediment. Uitzondering zijn de locaties waar onder invloed van de golfwerking slib regelmatig wordt opgewerveld (Van Maren and Wang, 2009). In de geulen bevindt zich tevens veel sediment van de platen en oevers, welke onder invloed van de vastere waterstand zijn afgekalfd (tot wel $100 \mathrm{~m} \mathrm{jaar}^{-1}$ ). In de jaren '80 heeft men de meeste oevers beschermd met vooroeververdedigingen, zoals te zien is op satellietbeelden (Figuur 23). Deze vooroeververdediging is aangelegd op een hoogte van 0,8 m NAP. Hoewel de oevererosie hierdoor drastisch is afgenomen, kan deze nog steeds optreden, zoals te zien is voor het zuiden van Tiengemeten (Figuur 23).

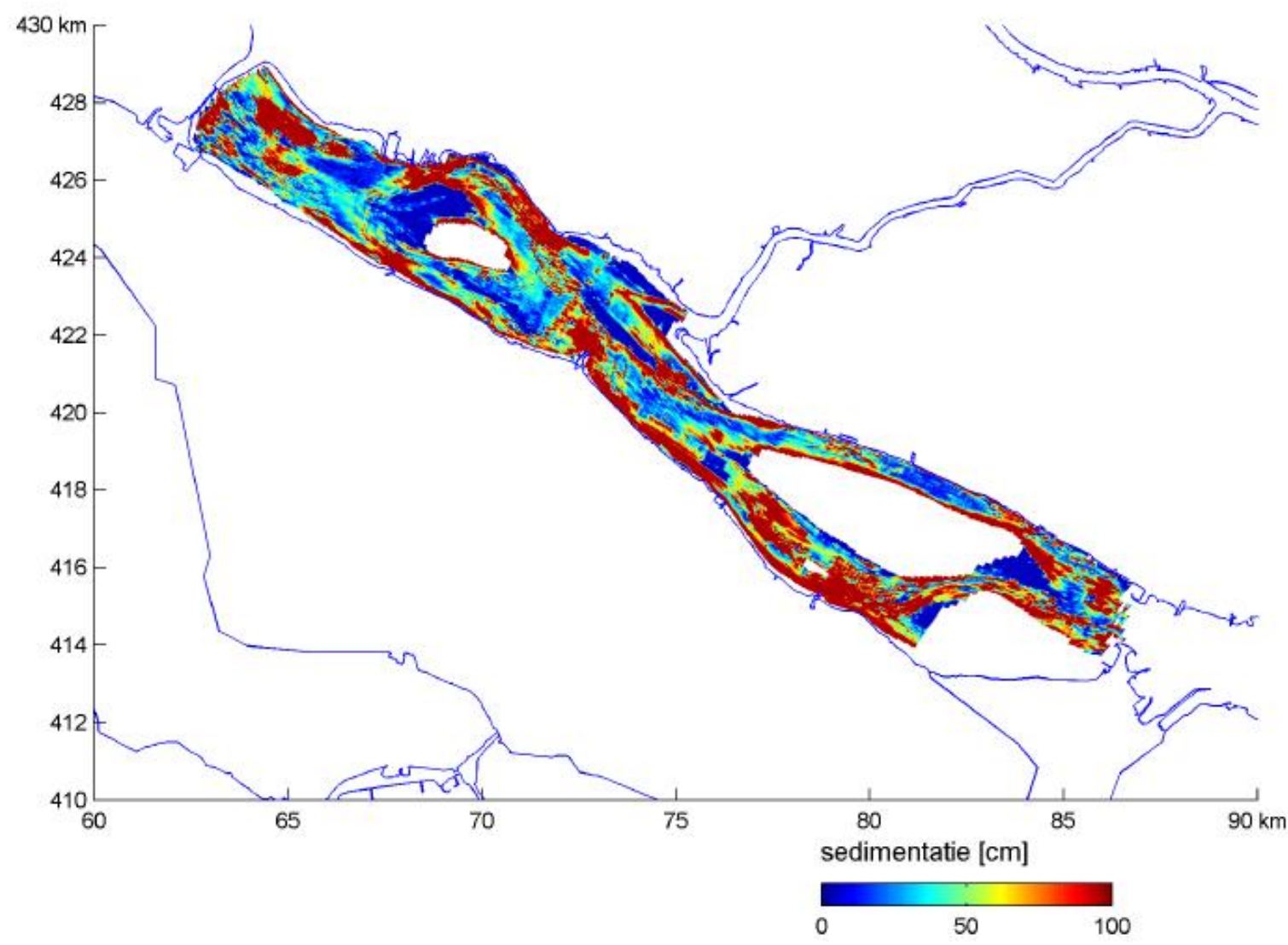

Figuur 22 Dikte afzetting in Haringvliet na 1972 (data van A. Fioole, Dir. Zuid Holland, periode waarover deze sedimentatie is opgetreden is niet vermeld. Bron: Van (Van Maren and Wang, 2009). 

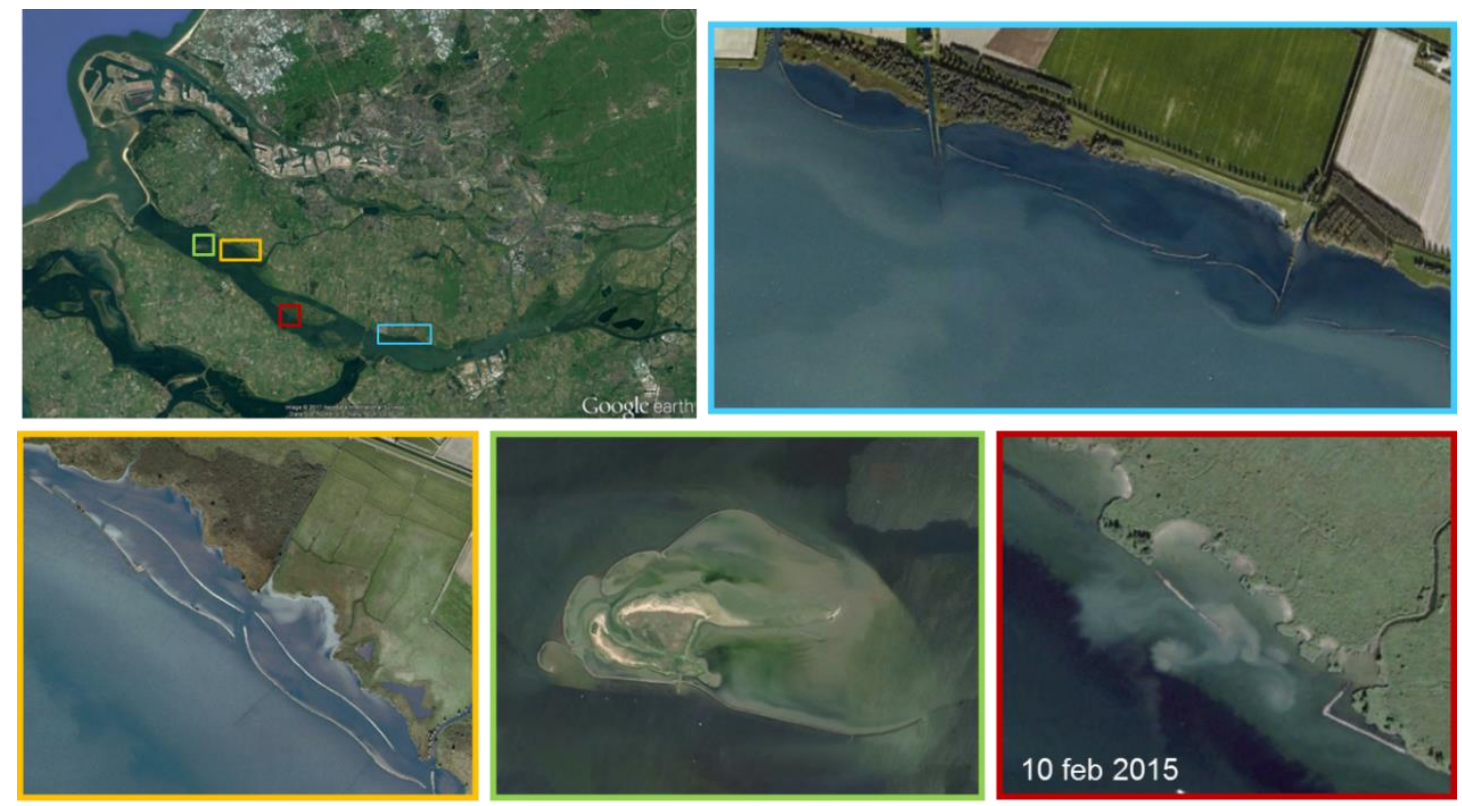

Figuur 23 Google Earth (c) beelden van de vooroeverberscherming op diverse locaties. Voor het zuiden van Tiengemeten (rode rechthoek), is op de satellietbeelden te zien dat een deel van de vooroeverbescherming verzakt of verdwenen is en dat oevererosie nog steeds plaats kan vinden (wolken van sediment te zien).

\subsubsection{Dynamiek bij alternatief stuurprogramma}

In het kader van deze studie zijn twee varianten onderzocht waarbij wordt uitgegaan van een alternatief stuurprogramma van de Haringvlietsluizen: de variant Stormvloedkering (en Klimaatscenario), waarbij de sluizen openstaan, tenzij de waterstand bij Hoek van Holland meer dan 2 $\mathrm{m}$ is, en de variant $80 \mathrm{~cm}$ getij, waarbij gestuurd wordt op een getijslag in het Haringvliet van $80 \mathrm{~cm}$. Op basis van de stroomsnelheden en waterstandsvariaties, wordt in deze paragraaf een inschatting gemaakt van de mogelijkheid tot het herstel van de plaat-geul dynamiek, het effect op de zandhonger en de mogelijke gevolgen voor oevererosie.

\subsubsection{Plaat-geul dynamiek}

Zoals gebleken is op basis van de waarnemingen in de Oosterschelde en Westerschelde, zijn de stroomsnelheden bepalend voor de plaatopbouw en ligt de kritische grens rond de $1 \mathrm{~m} \mathrm{~s}^{-1}$. Bij volledig geopende sluizen (variant stormvloedkering) zullen de stroomsnelheden het grootste zijn, maar nog steeds kleiner dan in de situatie vóór sluiting. Dit wordt veroorzaakt door de aanwezigheid van de constructie welke het doorstroomoppervlak in de monding flink beperkt, zie Figuur 24.

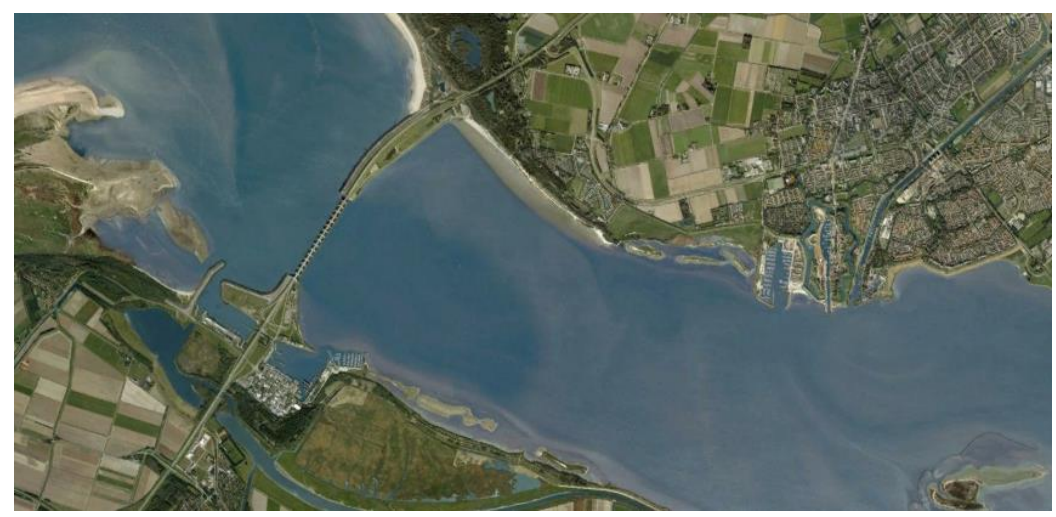

Figuur 24 Luchtopname van de Haringvlietsluizen (Bron: Google Earth @)). 
Voor diverse locaties in het Haringvliet en Hollands Diep zijn de met SOBEK-3 berekende stroomsnelheden (en waterstanden) geëvalueerd, zie Figuur 25. Hieruit blijkt dat de stroomsnelheden in het Haringvliet op de meeste locaties ruim onder de $1 \mathrm{~m} \mathrm{~s}^{-1}$ blijven, terwijl voorheen de stroomsnelheden bij Hellevoetsluis ruim boven de $1 \mathrm{~m} \mathrm{~s}^{-1}$ lagen. Ter hoogte van Moerdijk (HD_988.00_l) zijn de snelheden rond de 0,3 $\mathrm{m} \mathrm{s}^{-1}$, terwijl voorheen de snelheden hier rond de $0,8 \mathrm{~m} \mathrm{~s}^{-1}$ lagen. De snelheden bij de variant stormvloedkering zijn daarmee aanzienlijk lager dan vóór de sluiting en vergelijkbaar met de Oosterschelde (zie Figuur 19b) en dus Dit is onvoldoende voor een natuurlijke plaatopbouw.
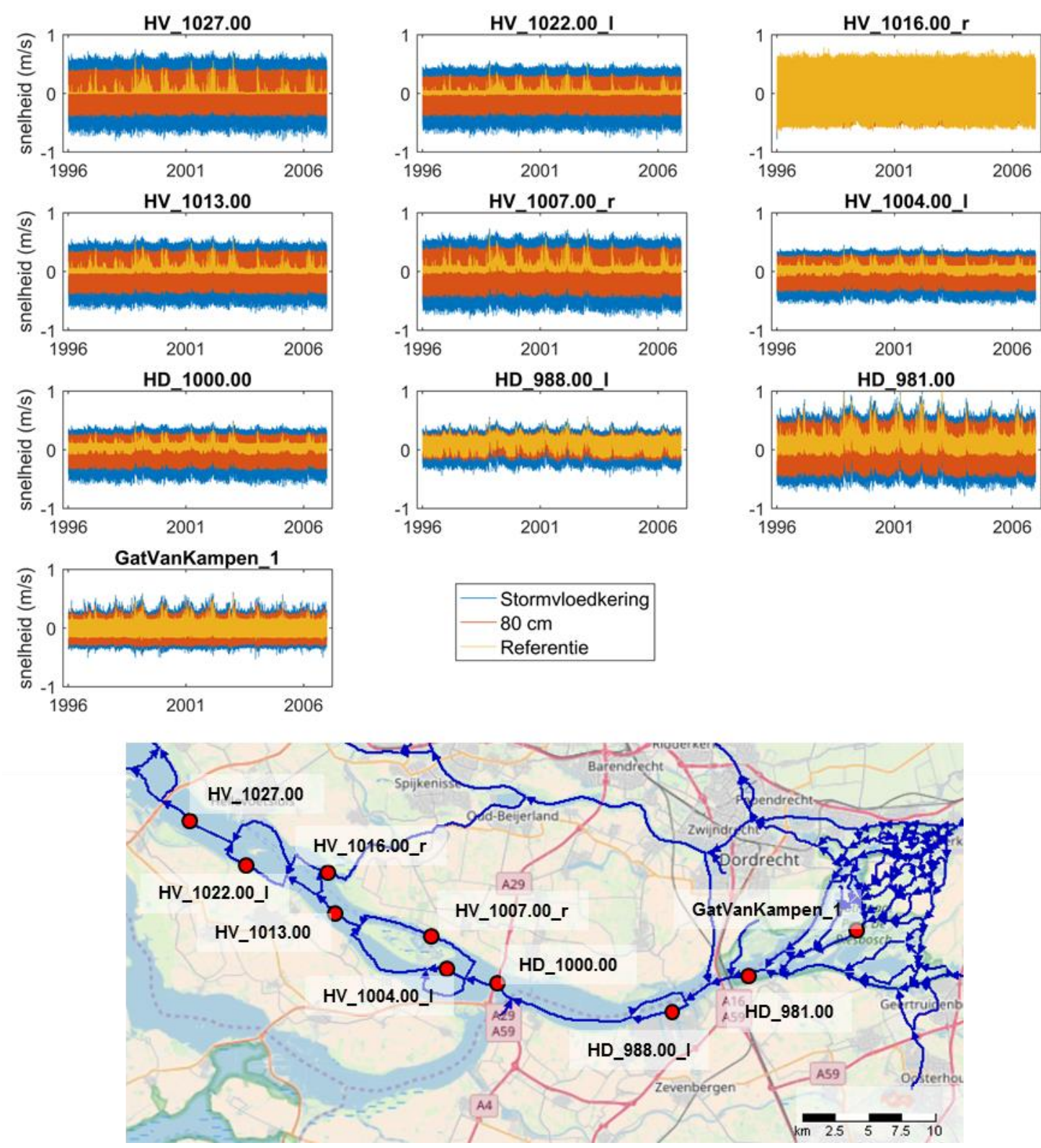

Figuur 25 Voor diverse locaties zijn de profielgemiddelde stroomsnelheden getoond, zoals berekend met SOBEK-3 (zie §4.1)

\subsubsection{Zandhonger en zeespiegelstijging}

Naast de vraag of er voldoende dynamiek in het systeem te krijgen is voor plaatopbouw, is er de vraag of er voldoende dynamiek en sediment aanwezig is om de zandhonger tegen te gaan. Op basis 
van een empirische evenwichtsrelatie zoals van O'Brien (1969) ${ }^{3}$, is tijdens de MER-studie

(Rijkswaterstaat, 1998c) het evenwichtsprofieloppervlak bepaald voor diverse varianten, zie Figuur 26.

Hieruit blijkt dat in de huidige situatie (nul-alternatief) een profieloppervlak van $\sim 1.000 \mathrm{~m}^{2}$ nodig is voor een dynamisch evenwicht. Afhankelijk van de locatie varieerden in 1995 de profieloppervlakken in het Haringvliet tussen de 17.000 à $25.000 \mathrm{~m}^{2}$ (Rijkswaterstaat, 1998c). Het profiel oppervlak moet dus nog zo'n 20 keer kleiner worden. Hoelang dit duurt, is afhankelijk van de hoeveelheid sediment die binnenkomt en kan sedimenteren. In de huidige situatie wordt geen sediment geïmporteerd vanuit zee en draagt alleen het slib en zand uit de rivieren bij aan de sedimentatie. Volgens diverse studies bedraagt de sedimentatie van riviersedimenten zo'n 1.000 à 3.000 kton per jaar (Houwing and Blom, 2001; Snippen et al., 2005; Becker, 2015). Bij gelijkblijvende sedimentatie zal het enkele honderden jaren duren voor een nieuw dynamisch evenwicht bereikt is, zie de berekening in Box 1 .

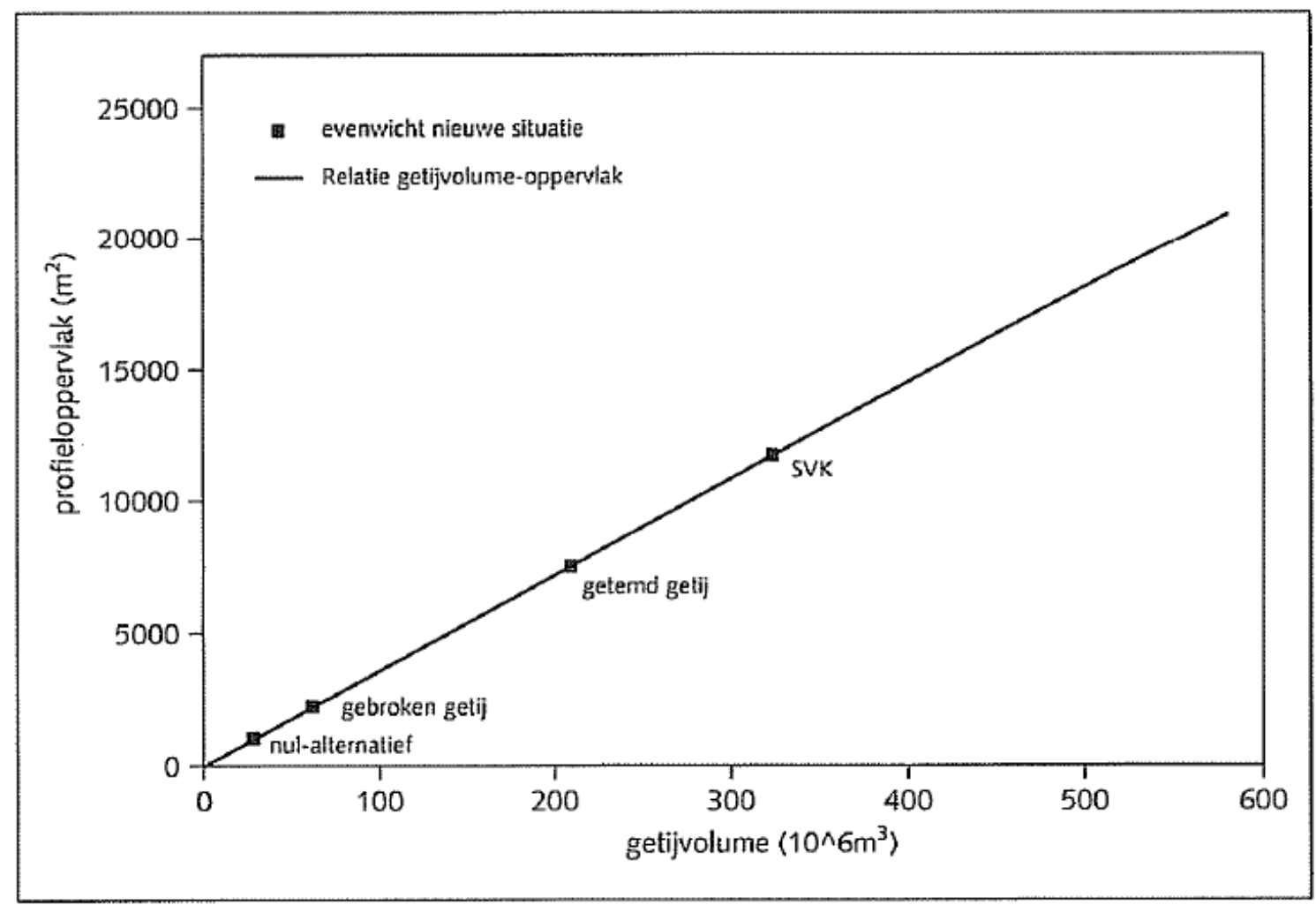

Figuur 26 Profieloppervlak per scenario, bepaald op basis van een evenwichtsrelatie voor estuaria. Bron: Rijkswaterstaat (1998a).

3 De MER-studie geeft niet aan welke evenwichtsrelatie is gebruikt, maar deze zal vergelijkbaar zijn aan die van O'Brien, M. (1969) Equilibrium flow areas of inlets on sandy coasts. Journal of the Waterways and Harbors Division; Proceedings of the American Society of Civil Engineers 95 (WW1): 43-52. 
Box 1: Morfologisch evenwicht

Hieronder volgen ruwe schattingen voor de tijd die het kost om een dynamisch evenwicht te bereiken bij een evenwichtsprofiel van

$1.000 \mathrm{~m}^{2}$ (afgeleid evenwichtsprofiel in de huidige situatie, met aansturing Haringvliet sluizen volgens $\mathrm{LPH}^{\prime} 84$ en huidige sedimentaanbod en sedimentatiesnelheid)

- $\quad 12.000 \mathrm{~m}^{2}$ (afgeleid evenwichtsprofiel voor het stormvloedkering-scenario en met huidig sedimentaanbod en sedimentatiesnelheid).

Tot slot wordt een schatting gegeven van de hoeveelheid slib die bij het stormvloedkering-scenario het Haringvliet binnen zou kunnen komen.

\begin{tabular}{llc}
\hline & Huidige situatie & Stormvloedkering \\
\hline Evenwichtsprofieloppervlak & $1.000 \mathrm{~m}^{2}$ & $12.000 \mathrm{~m}^{2}$ \\
Werkelijk profieloppervlak & $17.000-25.000 \mathrm{~m}^{2}$ & \\
Tekort aan profieloppervlak & $16.000-24.000 \mathrm{~m}^{2}$ & $5.000-13.000 \mathrm{~m}^{2}$ \\
Lengte Hollands Diep- Haringvliet* & $50.000 \mathrm{~m}(50 \mathrm{~km})$ & \\
Tekort aan volume & $0,8-1,2 \cdot 10^{9} \mathrm{~m}^{3}$ & $0,25-0,65 \cdot 10^{9} \mathrm{~m}^{3}$ \\
Sedimentatie van slib** & $700 \mathrm{kton} \mathrm{jaar}^{-1}\left(=9 \cdot 10^{5} \mathrm{~m}^{3} \mathrm{jaar}^{-1}\right)$ & \\
Sedimentatie van zand $* * *$ & $1.200 \mathrm{kton} \mathrm{jaar}^{-1}\left(=8 \cdot 10^{5} \mathrm{~m}^{3} \mathrm{jaar}^{-1}\right.$ & \\
Totale sedimentatie**** & $1.900 \mathrm{kton} \mathrm{jaar}^{-1}\left(=1,6 \cdot 10^{6} \mathrm{~m}^{3} \mathrm{jaar}^{-1}, \sim 1-2 \mathrm{~cm} \mathrm{jaar}^{-1}\right)$ \\
Aantal jaar morfologisch evenwicht bereikt & $500-700 \mathrm{jaar}^{2}$ & $150-400 \mathrm{jaar}$ \\
\hline
\end{tabular}

* aanname dat het tekort aan profieloppervlak geldt voor Hollands Diep en Haringvliet. Omdat er tot op heden meer aanzanding heeft opgetreden in het Hollands Diep dan in het Haringvliet is het tekort aan profieloppervlak voor het Hollands Diep vermoedelijk kleiner. Voor een schatting van de orde grootte van het tekort aan sediment, worden huidige getallen voldoende goed geacht.

** gemiddelde waarde uit de diverse sedimentbalansen en een droge stof dichtheid voor slib van $800 \mathrm{~kg} \mathrm{~m}^{-3}$

*** gemiddelde waarde uit de diverse sedimentbalansen en een droge stof dichtheid voor zand van $1.600 \mathrm{~kg} \mathrm{~m}^{-3}$

$* * * *$ Oppervlak Haringvliet en Hollands Diep: $~ 12.000$ ha.

\section{Schatting aanvoer slib vanuit zee, voor het stormvloedkering-scenario}

\section{Getijvolume:}

Getijvolume per jaar:

Concentratie slib in de Voordelta****:

Slib aanvoer uit zee:

$3,8 \cdot 10^{8} \mathrm{~m}^{3}$ (zie Figuur 26)

$2,7 \cdot 10^{11} \mathrm{~m}^{3}$ jaar $^{-1}$ (706 getijden per jaar)

$30 \mathrm{~g} \mathrm{~m}^{-3}$

8.000 kton jaar $^{-1}$

**** bron: waarden voor Goeree 2 en Rockanje badstrand uit waterbase en op waterbase gebaseerde kml:

http://live. waterbase.nl/

http://kml.deltares.nl/kml/rijkswaterstaat/waterbase/water_volume_transport_into_sea_water_from_rivers.kml

Dit is een orde grootte meer dan aanvoer vanuit de rivieren. Stel dat slechts $10 \%$ bezinkt, dan is de hoeveelheid aanslibbing vanuit zee qua orde grootte gelijk aan die vanuit de rivier. Let wel, bij het stormvloedkering-scenario, zijn de stroomsnelheden vele malen hoger dan in de huidige situatie (Figuur 25). Er zal dus veel minder slib sedimenteren en mogelijk zelfs erosie van slib optreden.

Uit Figuur 26 blijkt dat met de variant stormvloedkering het profieloppervlak voor een dynamisch evenwicht een factor 1,5 à 2 groter is dan in de huidige situatie, namelijk $\sim 12.000 \mathrm{~m}^{2}$. Uitgaande van een vergelijkbaar sedimentaanbod en sedimentatie als in de huidige situatie zal het naar schatting nog steeds ruim meer dan 100 jaar duren voor een nieuw dynamische evenwicht is bereikt, zie de berekening in het blauwe kader. Bij de variant stormvloedkering zal er qua sedimentaanbod en sedimentatie echter een aantal dingen veranderen. Enerzijds wordt sedimentaanbod vanuit de Voordelta weer mogelijk. Vanwege de hoge zeewaartse sluisdrempel (ruim $6 \mathrm{~m}$ boven de 
zeebodemligging, zie Figuur 6), zal zand niet of in zeer beperkte mate het Haringvliet binnen kunnen binnenkomen. Het slib dat zich in de hele waterkolom bevindt, zal wel kunnen binnenkomen. Het zou hierbij om aanzienlijke hoeveelheden kunnen gaan, welke een vergelijkbare orde grootte of zelfs meer dan het rivierslib kan betreffen (zie blauw kader voor toelichting). Hoeveel van dit slib zal kunnen bezinken is de vraag. Vanwege de toegenomen stroomsnelheden in het Haringvliet (zie Figuur 25) kan het zijn dat maar een zeer beperkt aandeel van het slib zal bezinken. Dit geldt ook voor het rivierslib. Volgens de MER-Haringvlietsluizen (Rijkswaterstaat, 1998c) is het zelfs aannemelijk dat erosie van fijn sediment kan gaan optreden. Dus hoewel voor het stormvloedkering-scenario het evenwichtsprofieloppervlak significant minder afwijkt van het huidige profieloppervlak, zal de sedimentatie door de verhoogde stroomsnelheden verminderen en dus relatief langzamer naar het nieuwe evenwicht toegroeien.

Tot slot is de vraag of de zandhonger zal toenemen als gevolg van zeespiegelstijging. Met zeespiegelstijging neemt de waterdiepte toe, tenzij de bodem met dezelfde snelheid meestijgt, zie illustratie in Figuur 27. De huidige snelheid van de zeespiegelstijging is $0,2 \mathrm{~cm}$ jaar ${ }^{4}$. De huidige sedimentatiesnelheid van het Haringvliet en Hollands Diep varieert tussen de 0,2 en $2 \mathrm{~cm}_{\text {jaar }}{ }^{-1}$ (Snippen et al., 2005; Becker, 2015). Bij gelijkblijvende sedimentatiesnelheid en zeespiegelstijging zal de bodem dus in staat zijn om mee te groeien en zal zandhonger niet toenemen. Wel zal het langer duren voor een nieuw morfologisch evenwicht is bereikt. Alleen wanneer de zeespiegelstijging gaat versnellen of de sedimentatiesnelheid gaat afnemen bestaat de kans op toename van zandhonger. Dit alleen als de zeespiegelstijging sneller gaat dan de sedimentatiesnelheid.
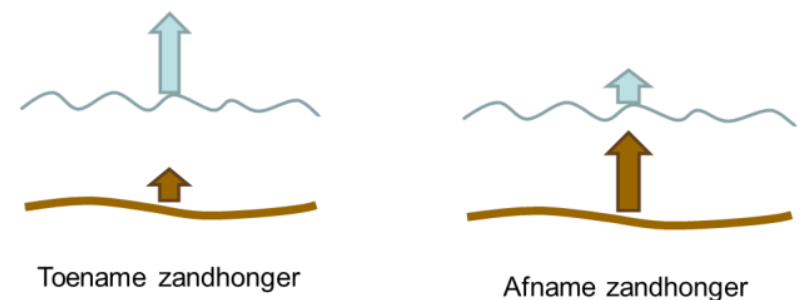

Afname zandhonger

Haringvliet-Hollandsch Diep

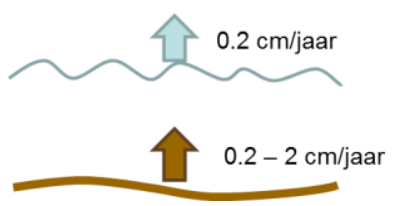
$\rightarrow$ Geen toename zandhonger, gaat wel langer duren voor morfologische evenwicht is bereikt

Figuur 27 Illustratie zandhonger en invloed zeespiegelstijging.

\subsubsection{Oevererosie en vooroeverbescherming}

In de huidige situatie wordt de erosieve kracht van de golven geconcentreerd op een klein gebied, wat gezien de huidige waterstandvariantie gemiddeld zo'n $40 \mathrm{~cm}$ is. Dit heeft geleid tot flinke oevererosie. Om deze te beperken, is in de jaren ' 80 van de vorige eeuw vooroeverbescherming aangelegd met een originele kruinhoogte van $+0,8 \mathrm{~m} \mathrm{NAP}$, waarvan inmiddels een deel behoorlijk is verzakt ${ }^{5}$. Daarnaast is ook een groot deel van de oevers bestort of bekleed.

Bij de varianten $80 \mathrm{~cm}$ getij en stormvloedkering zullen de waterstandsvariaties aanzienlijk toenemen tot respectievelijk 0,8 m en 1,4 m, (zie §4.3.3, §4.3.4 en de tabellen in Bijlage 2 en Bijlage 3). Wat de gevolgen zullen zijn voor de erosie van oevers, platen en slikken, hangt ervan af van of deze beschermd zijn of niet. Voor onbeschermde oevers geldt dat de golfinvloed door de grotere waterstandsvariatie over een groter bereik wordt verdeeld. Hierdoor zal de erosie afnemen en zullen de oevers een meer geleidelijk talud krijgen. Uit Figuur 28 blijkt echter dat nagenoeg alle oevers beschermd zijn met vooroeverbescherming of bestorting. Uitzonderingen zijn diverse oevers in de Biesbosch en enkele locaties langs het Haringvliet. Voor de Biesbosch is vermoedelijk minder

\footnotetext{
${ }_{5}^{4} \mathrm{http}: / /$ www.clo.nl/indicatoren/nl0229-zeespiegelstand-nederland-en-mondiaal

${ }^{5}$ persoonlijke communicatie met RWS-WNZ, Linda van Veen-Kamp, 14-08-2017
} 
bescherming nodig, omdat dit gebied beschutter ligt voor golfinvloed en begroeid is. Voor het Haringvliet gaat het om twee locaties, een recreatiestrand, welke waarschijnlijk wordt onderhouden, en de noordkant naast de sluizen, en de noordkant van Tiengemeten, waar de golfinvloed minder sterk is.

Meest relevant is daarom wat de gevolgen zullen zijn voor de beschermde gebieden. De vooroeverbescherming is erop gericht om de golven te breken. Ten opzichte van de variant Huidig beheer, zal de waterstandvariatie toenemen. Omdat ook de middenstand daalt, zullen de grootste verschillen in waterstand in het onderste bereik optreden, zie Figuur 25 . Boven de $+0,8$ m NAP nemen de waterstanden maar in beperkte mate toe. Verwacht wordt daarom dat ook met de stormvloedkering variant de vooroeverbescherming de golven voldoende zullen blijven breken. Wel zal bij extreme condities de effectiviteit afnemen.

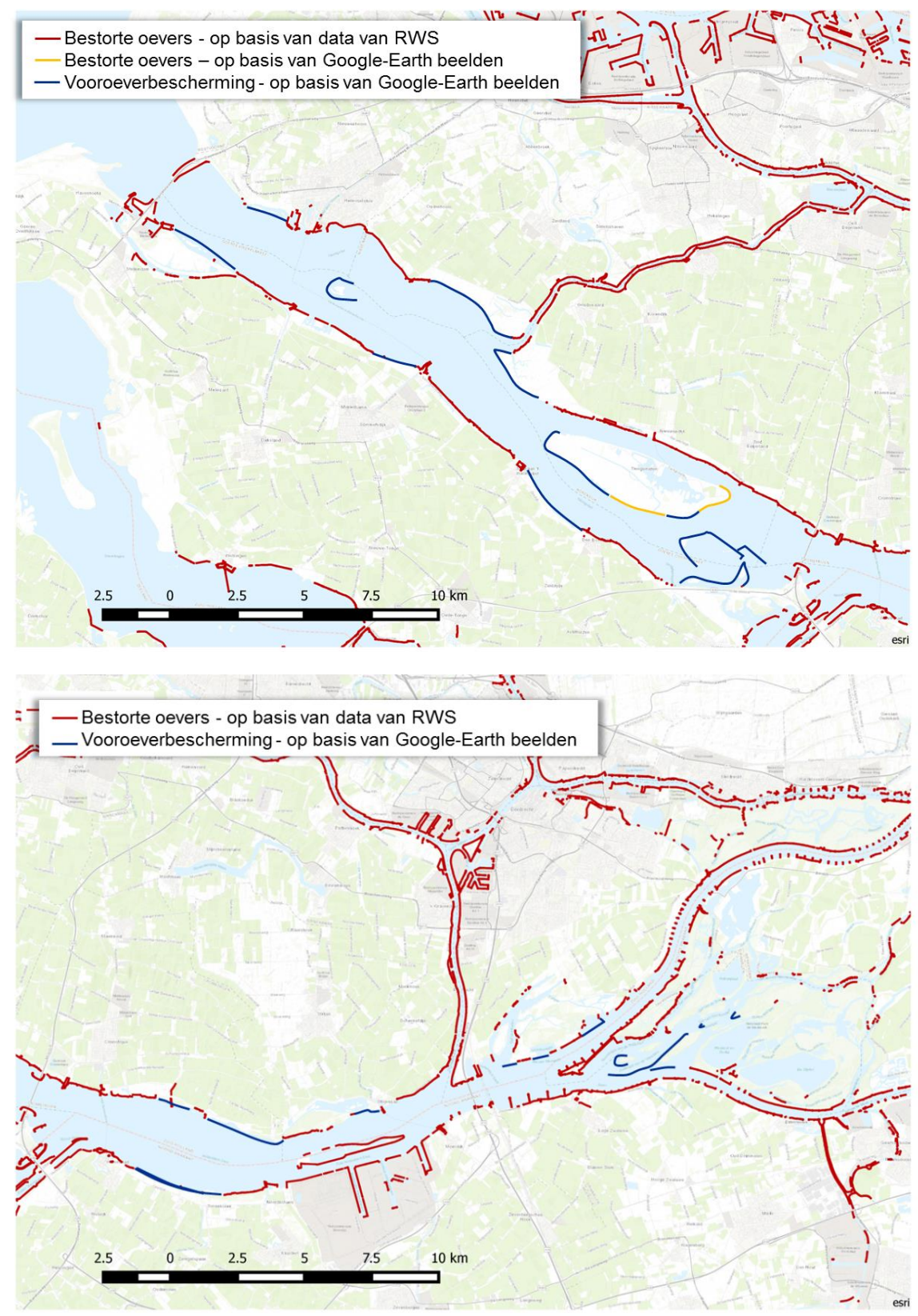

Figuur 28 Overzicht beschermde oevers in Haringvliet (bovenste figuur) en Hollands-Diep/ Biesbosch. Voor de bestorte oevers zijn gegevens beschikbaar bij Rijkswaterstaat, Dienst West Nederland Zuid. De vooroeverbescherming is in kaart gebracht op basis van Google-Earth beelden. 

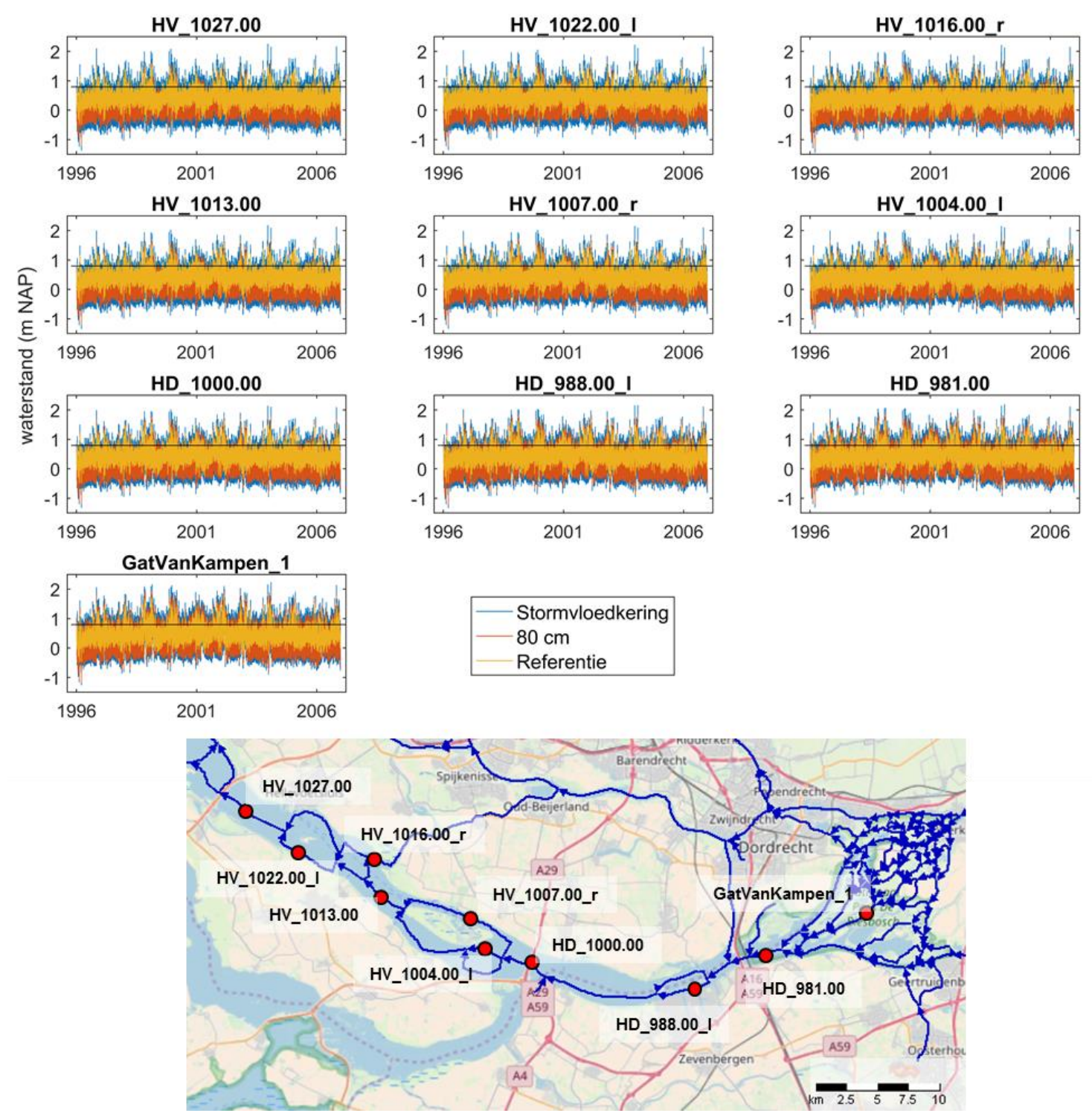

Figuur 29 Voor diverse locaties zijn de waterstanden getoond, zoals berekend met SOBEK-3 (zie §4.1. Zwarte lijn op 0,8 m NAP geeft de hoogte van de vooroeverberscherming weer.

$$
Q(t)=O \frac{d h(t)}{d t}, \quad \text { met } \operatorname{dh}(t)=\frac{\Delta h}{2} \sin \left(\frac{2 \pi t}{T}\right)
$$

Waarbij:

$O \quad$ Oppervlak achter de oeverbescherming $\left[\mathrm{m}^{2}\right]$

$d h(t) / d t \quad$ Waterstandsvariatie in de tijd $\left[\mathrm{m} \mathrm{s}^{-1}\right]$

$Q(\mathrm{t}) \quad$ Afvoer $\left[\mathrm{m}^{3} / \mathrm{s}\right]$

$\Delta h \quad$ Waterstandsverschil binnen een getijperiode [m]

$t \quad$ Tijd [s]

$T \quad$ Getijperiode [s]

De maximale afvoer en stroomsnelheid die optreden zijn dan:

$$
Q_{\max }=O \frac{\pi \Delta h}{T}=A v_{\max }
$$

A Doorstroomoppervlak van de opening $\left[\mathrm{m}^{2}\right]$

$v \quad$ Snelheid in de opening $\left[\mathrm{m} \mathrm{s}^{-1}\right]$ 
Steekproefsgewijs is voor enkele locaties, zoals weergegeven in Figuur 30, een eerste schatting gemaakt van de verandering in stroomsnelheid in de doorgangen. Hieruit blijkt dat zelfs bij de variant stormvloedkering, waarbij de waterstanden het sterkste variëren, de orde grootte van de snelheden gemiddeld rond 10 à $15 \mathrm{~cm} \mathrm{~s}^{-1}$ zijn voor alle geëvalueerde gebieden, zie rekenvoorbeeld in blauw kader. Bij extreme waterstandsverschillen kan dit een enkele keer oplopen tot ruim $20 \mathrm{~cm} \mathrm{~s}^{-1}$. Hiermee lijken de stroomsnelheden voldoende laag om geen (substantiële) erosie te veroorzaken in de doorgangen. Opmerkelijk is wel dat RWS heeft aangegeven dat de vooroeverbescherming op diverse locaties is verzakt. Uit Google-Earth beelden blijkt dit bijvoorbeeld het geval te zijn voor de locatie bij Tiengemeten. In het satellietbeeld van mei 2016 is de oeverbescherming weer intact (zie Figuur 30), maar uit de satellietbeelden van voor 2015 zijn grote delen van de vooroeverbescherming onzichtbaar en dus waarschijnlijk verzakt. Mogelijk dat deze verzakkingen veroorzaakt worden door erosie door golfwerking of stroming langs de dammen. De stroming langs de dammen zal naar verwachting hoger worden met een grotere sluisopening en kan daarmee een mogelijk risico vormen voor de stabiliteit van de vooroeverbescherming. Dit blijft dus een aandachtspunt.
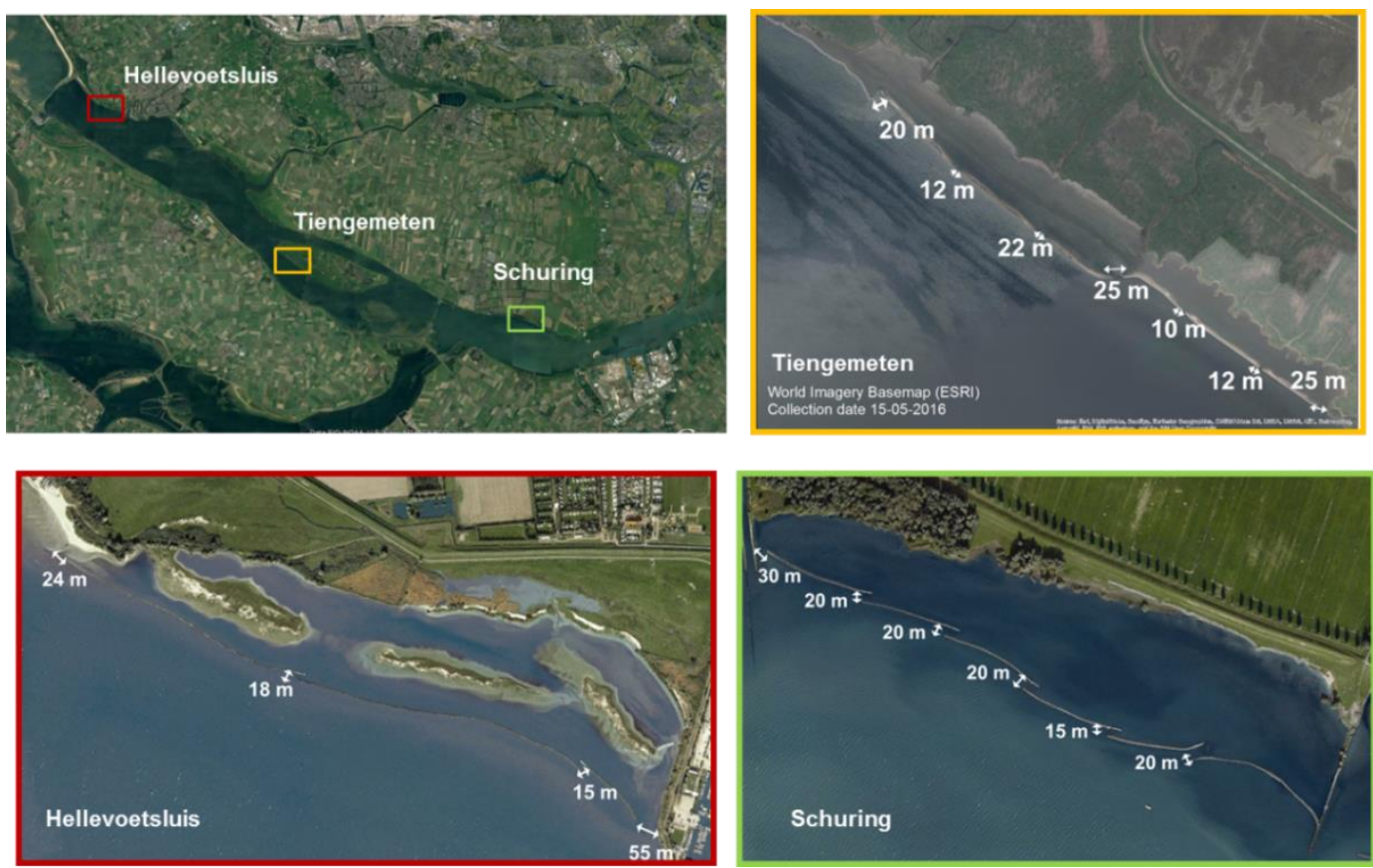

Figuur 30 Drie locaties waarvoor is een eerste schatting is gemaakt van het effect van een grotere getijslag op de vooroeververdediging (Foto's Google Earth (C)). 
Box 2: Rekenvoorbeeld voor Hellevoetsluis

Algemene kenmerken

(zie Figuur 30 voor het kombergingsgebied nabij Hellevoetsluis en de afmetingen van de vier doorgangen) Oppervlak kombergingsgebied: $\quad 350000 \mathrm{~m}^{2}$

Getijperiode: $\quad 44700 \mathrm{~s}$ (=12 uur en $25 \mathrm{~min})$;

Doorgang 1: $\quad b=24 \mathrm{~m}, \mathrm{~h}_{\text {bodem }}=+0,5 \mathrm{~m} \mathrm{NAP}$;

Doorgang 2: $\quad b=18 \mathrm{~m}, \mathrm{~h}_{\text {bodem }}=-1,5 \mathrm{~m} \mathrm{NAP}$;

Doorgang 3: $\quad b=15 \mathrm{~m}, \mathrm{~h}_{\text {bodem }}=-1,2 \mathrm{~m} \mathrm{NAP}$;

Doorgang 4: $\quad b=55 m, h_{\text {bodem }}=-2,8 m$ NAP;

\begin{tabular}{|c|c|c|c|}
\hline & Huidig & $80 \mathrm{~cm}$ & SVK \\
\hline$\Delta \mathrm{h}_{\text {gemiddeld }}$ (Hellevoetsluis) $[\mathrm{m}]$ & 0,42 & 0,80 & 1,30 \\
\hline $\mathrm{Q}_{\max }=0 \cdot \Pi \cdot \Delta \mathrm{h}_{\mathrm{gem}} / \mathrm{T}\left[\mathrm{m}^{3} \mathrm{~s}^{-1}\right]$ & 10 & 20 & 32 \\
\hline $\mathrm{h}_{\text {gemiddeld }}$ (Hellevoetsluis) [m NAP] & 0,51 & 0,30 & 0,25 \\
\hline Atotaal bij gemiddelde waterstand $\left[\mathrm{m}^{2}\right] *$ & 244 & 225 & 221 \\
\hline $\mathrm{v}_{\mathrm{gem}}=\mathrm{Q} / \mathrm{A}\left[\mathrm{m} \mathrm{s}^{-1}\right]$ & 0,04 & 0,09 & 0,14 \\
\hline$\Delta \mathrm{h}_{\text {extreem }}$ (Hellevoetsluis) $* *[\mathrm{~m} \mathrm{NAP}]$ & 1,32 & & 2,42 \\
\hline$Q_{\max , \text { extreem }}=0 \cdot \Pi \cdot \Delta \mathrm{h}_{\text {extr }} / \mathrm{T}\left[\mathrm{m}^{3} \mathrm{~s}^{-1}\right]$ & 32 & & 60 \\
\hline$V_{\text {max }}$ extreem $=Q / A\left[\mathrm{~m} \mathrm{~s}^{-1}\right]$ & 0,13 & & 0,27 \\
\hline
\end{tabular}

* Voor de bepaling van het totale doorstroomoppervlak is de som van de individuele doorstroomoppervlakken gebruikt. Hierbij is uitgegaan van het doorstroomoppervlak bij gemiddelde waterstand. Indien het doorstroomoppervlak hierbij negatief is, is de doorgang gesloten en telt deze niet mee voor het totale doorstroomoppervlak.

** voor het extreme waterstandsverschil is de $\Delta h_{\max }$ uit Tabel 6 en Tabel 11 gebruikt. Dit is niet het maximale waterstandsverschil dat optreedt binnen een getij, maar het verschil tussen het maximale en minimale opgetreden waterstand. Dit is dus een overschatting van wat er maximaal aan waterstandsverschil kan optreden binnen een getij.

Tot slot kan met name fijn sediment worden ingevangen door de vooroeverbescherming, waardoor oevers, platen of slikken kunnen aangroeien. In de afgelopen jaren is dit onder andere gebeurd voor de Slijkplaat en de platen en slikken ten zuidoosten van Tiengemeten, zie Figuur 31.

Of met een grotere sluisopening meer slib ingevangen kan worden hangt af van het uitwisselingsdebiet en de hoeveelheid sediment die kan bezinken. Hoe groter het uitwisselingsdebiet en hoe meer sediment in de waterkolom, hoe meer sediment uitgewisseld kan worden. Indien de stroomsnelheden achter de verdediging voldoende laag zijn, zal een toename van de sedimentflux leiden tot een toename van de sediment invang. Voor de beschouwde varianten geldt dat door de grotere waterstandsvariatie het uitwisselingsdebiet zal toenemen. Daarnaast wordt verwacht dat er zich meer slib in de waterkolom zal bevinden door toename van slibaanvoer vanuit de buitendelta en de hogere stroomsnelheden in het Haringvliet. Omdat de stroomsnelheden achter de vooroeverbescherming voldoende laag zullen zijn voor sediment om te bezinken, wordt daarom verwacht dat er een toename zal zijn van de slib invang. Dit zal een positief effect hebben op de aangroei van slikken, platen en oevers. Een schatting van de sedimentatiesnelheid vergt een uitgebreidere analyse op basis van aanvullende berekeningen en data en was niet mogelijk binnen de scope van de huidige studie. Mogelijk dat het ontwerp van de vooroeverbescherming of het gebruik van een bepaald type vegetatie de sedimentatiesnelheid kan bevorderen, maar ook dit vergt een uitgebreidere analyse. 


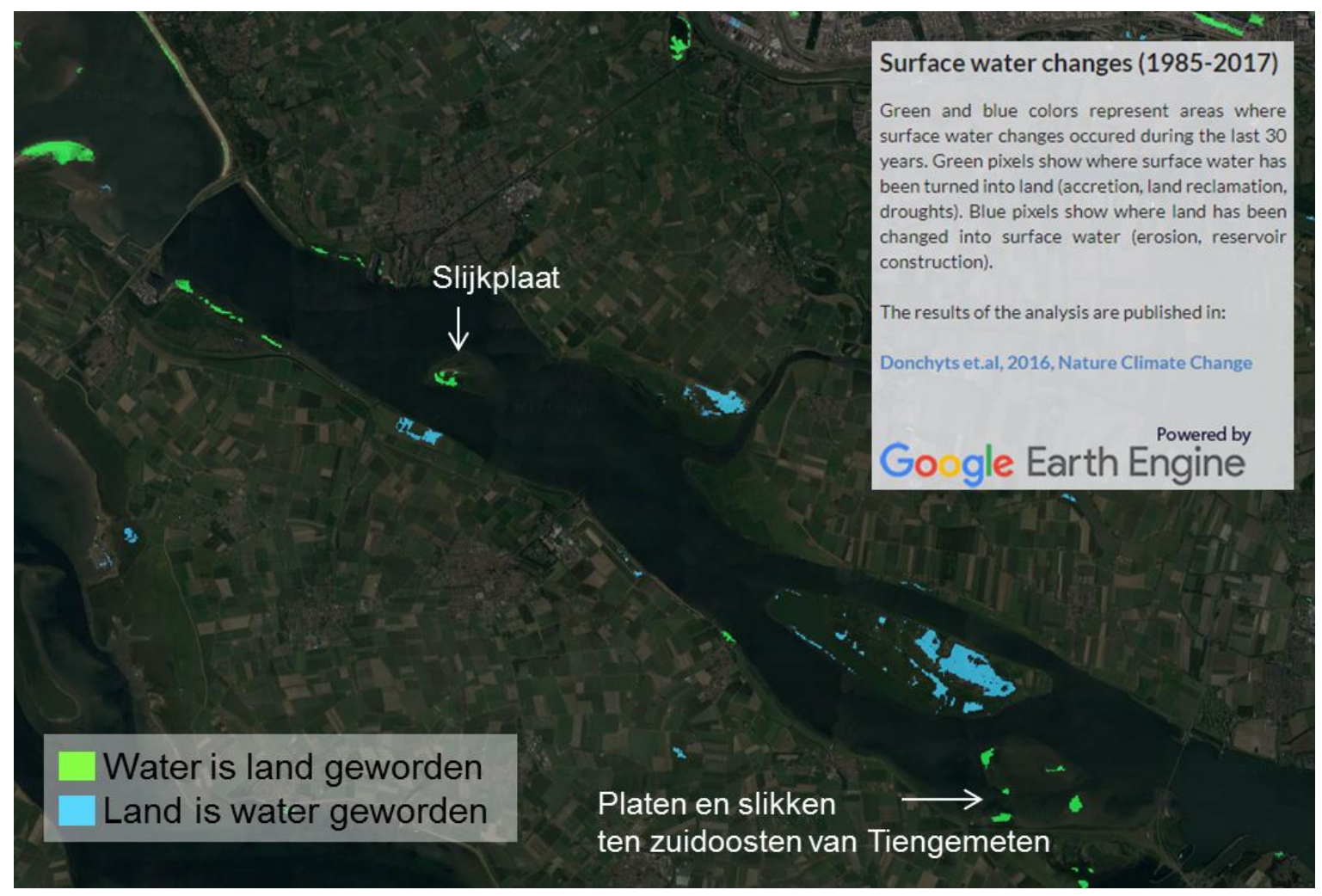

Figuur 31 Beeld van het Haringvliet uit de Aquamonitor, waarop voor de periode 1985-2017 te zien is welke gebieden van water land zijn geworden (groen) en welke gebieden van land water zijn geworden (blauw).

\subsubsection{Vervuild slib}

Na sluiting van het Haringvliet heeft zich tot de jaren '80 vervuild rivierslib afgezet in het Haringvliet en Hollands Diep. Het is niet wenselijk als dit verontreinigd sediment erodeert en naar de Noordzee wordt getransporteerd. In de huidige situatie treedt erosie op onder invloed van golfwerking of hoge rivierafvoeren (Van Maren and Wang, 2009). Met een ander sluisbeheer bestaat het risico op toenemende erosie wat onwenselijk is. Vandaar dat hier in de MER-studie een verkennend onderzoek naar is uitgevoerd waar uit blijkt dat met name voor de variant stormvloedkering de kans groot is op de erosie van slib (Rijkswaterstaat, 1998c), zie Figuur 32. Deze erosie zal waarschijnlijk voornamelijk optreden in de diepere geulen (Rijkswaterstaat, 1998c), waar zich juist het meeste van het vervuilde sediment heeft verzameld, door enerzijds sedimentatie van het vervuilde rivierslib en anderzijds vervuild slib uit de oevers die kort na sluiting zijn afgekalfd en in de geulen terecht is gekomen. De MER studie concludeert daarom dat meer onderzoek nodig is om de werkelijk effecten beter in kaart te brengen, maar als eerste schatting wordt gesteld dat het stormvloedkering-scenario niet uitgevoerd kan worden zonder bodemsaneringsmaatregelen (Rijkswaterstaat, 1998c). In de huidige studie is ook de variant $80 \mathrm{~cm}$ getij beschouwd. Of ook bij dit scenario de kans op erosie van slib groot is, kan niet zonder aanvullend onderzoek bepaald worden.

Indien een alternatief stuurprogramma wordt overwogen is het nuttig om een ruimtelijk beeld te krijgen van waar de meeste erosie op zal treden en of dit samenvalt met de vervuilde locaties. Dit kan bepaald worden middels slibmodellering of aan de hand van bodemschuifspanningen berekend uit bestaande 2D modellen, zoals door Van Maren and Wang (2009) is gedaan voor het huidige beheer en het kierscenario. 


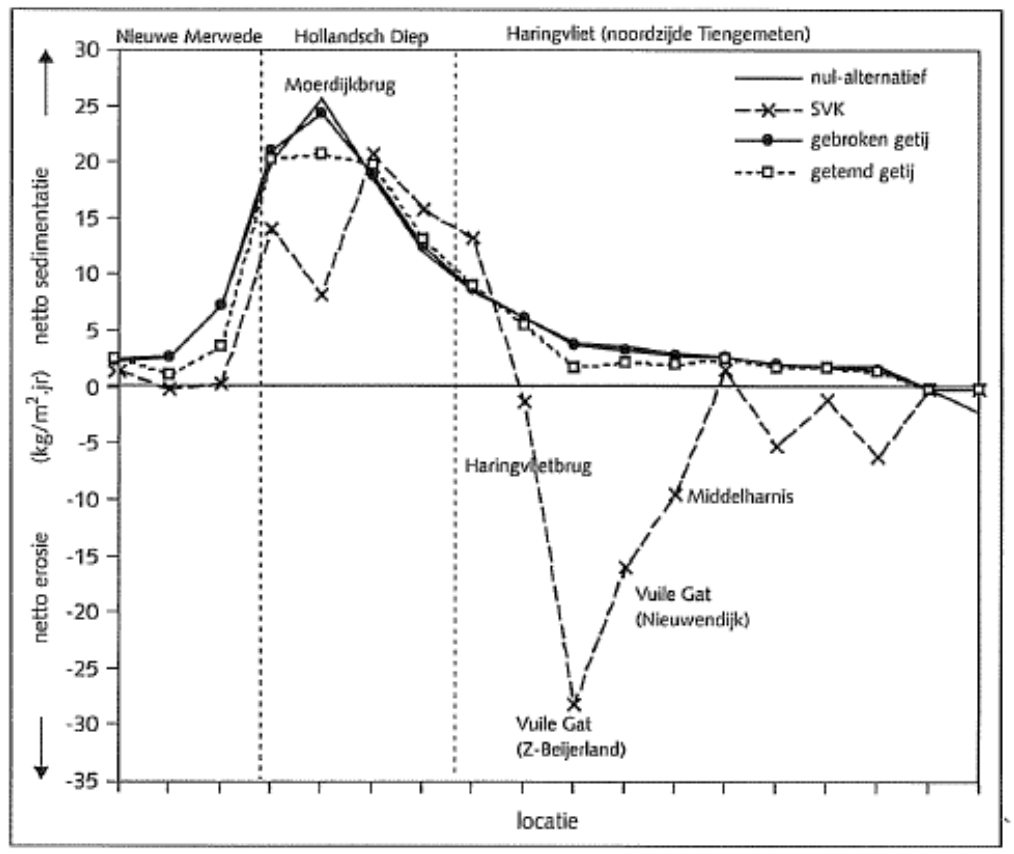

Figuur 32 Netto sedimentatie korte termijn, bepaald met DELWAQ voor het traject Nieuwe MerwedeHollands Diep - Haringvliet. Bron:Rijkswaterstaat (1998a).

\subsubsection{Bodembescherming Haringvlietsluizen}

Wanneer de sluizen verder opengaan, zullen de lokale stroomsnelheden door en nabij de sluizen toe gaan nemen. Hierdoor kunnen diepe ontgrondingskuilen ontstaan, welke een risico kunnen vormen voor de stabiliteit van de constructie. Hier is met de aanleg van de sluizen rekening mee gehouden en bodembescherming aangelegd. Of dit voldoende is, is niet zeker ${ }^{6}$. Ook bij de Oosterscheldekering is bodembescherming aanwezig. Toch zijn hier in de loop van de tijd zeer diepe kuilen ontstaan nabij de kering. In 2013 is hierover door een aantal ingenieurs aan de Tweede Kamer en Provinciale Staten een brandbrief gestuurd. Naar aanleiding hiervan zijn maatregelen getroffen. Met het oog op de problematiek rond de Oosterscheldekering is het van belang de situatie nabij de Haringvlietsluizen goed in kaart te brengen alvorens met een alternatief sluisbeheer te starten.

\subsubsection{Morfologische ontwikkelingen in de Rijn-Maasmonding}

De afsluiting van het Haringvliet heeft grote gevolgen gehad voor de morfologische ontwikkelingen in de hele Rijn-Maasmonding, zie Figuur 33. Voor de afsluiting van het Haringvliet was het getij in de noordelijke takken (Nieuwe-Waterweg, Nieuwe Maas) en zuidelijke takken (Haringvliet en Hollands Diep) vergelijkbaar en in fase met elkaar. Na de afsluiting is de getijvariatie gelijk gebleven in noordelijke takken, maar afgenomen in de zuidelijke takken en bovendien uit fase geraakt met de noordrand. Waar het voor sluiting gelijktijdig vloed en eb was in de noordelijke en zuidelijke takken, is het sinds de afsluiting tijdens vloed in de noordelijke takken, eb in de zuidelijke takken en vice versa. Hierdoor zijn de waterstandsverschillen tussen de noordelijke en zuidelijke takken gegroeid met als gevolg een toename van de hoeveelheid water dat bij elk getij door de verbindende takken (Oude Maas, Spui, Noord en Dordtsche Kil) moet stromen. Door de toegenomen stroomsnelheden zijn deze riviertakken sterk gaan eroderen, een trend die zich tot op heden voortzet, zie Figuur 33 en Figuur 34.

Tevens zijn er door de heterogeniteit van de ondergrond vele ontgrondingskuilen aanwezig die door de toegenomen stroomsnelheden sterk zijn gegroeid (Sloff et al., 2013; Huismans et al., 2016; Hoitink et al., 2017; Koopmans, 2017). Momenteel is er veel aandacht voor deze ontgrondingskuilen, omdat ze een risico kunnen vormen voor de stabiliteit van de keringen en overige infrastructuur (brugpijlers, kribben, kabels en tunnels). Wanneer de sluizen verder opengaan zullen de stroomsnelheden in de

\footnotetext{
${ }^{6}$ Tijdens de aanleg hebben de Haringvlietsluizen al een tijdje als stormvloedkering gefungeerd. Dit was echter voor een beperkte periode en niet voor tientallen jaren of langer
} 
verbindende takken weer afnemen. Uit verkennende berekeningen blijkt dat voor het kier-scenario de afname zeer beperkt zal zijn en dit nauwelijks invloed heeft op de huidige erosietrends in de verbindende takken (Buschman et al., 2015; Ottevanger and Van Der Mark, 2016). Hoewel ook bij de stormvloedkering variant de stroomsnelheden niet terug zullen worden gebracht tot naar het niveau van voor de afsluiting, zullen de stroomsnelheden wel flink afnemen waardoor de huidige erostrends af zullen nemen (Van Der Sligte, 2012; Buschman et al., 2015). Aanvullende berekeningen kunnen meer inzicht geven in de mate van afname.

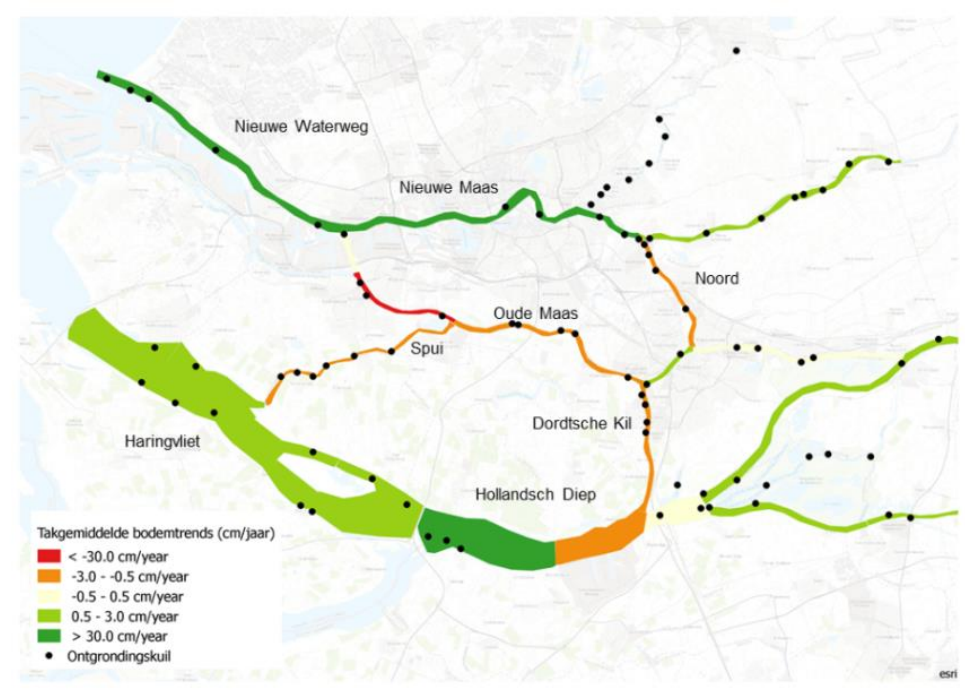

Figuur 33 Huidige takgemiddelde bodemtrends, met locaties geïdentificeerde ontgrondingskuilen. Bron data: Huismans and Van Duin (2016).

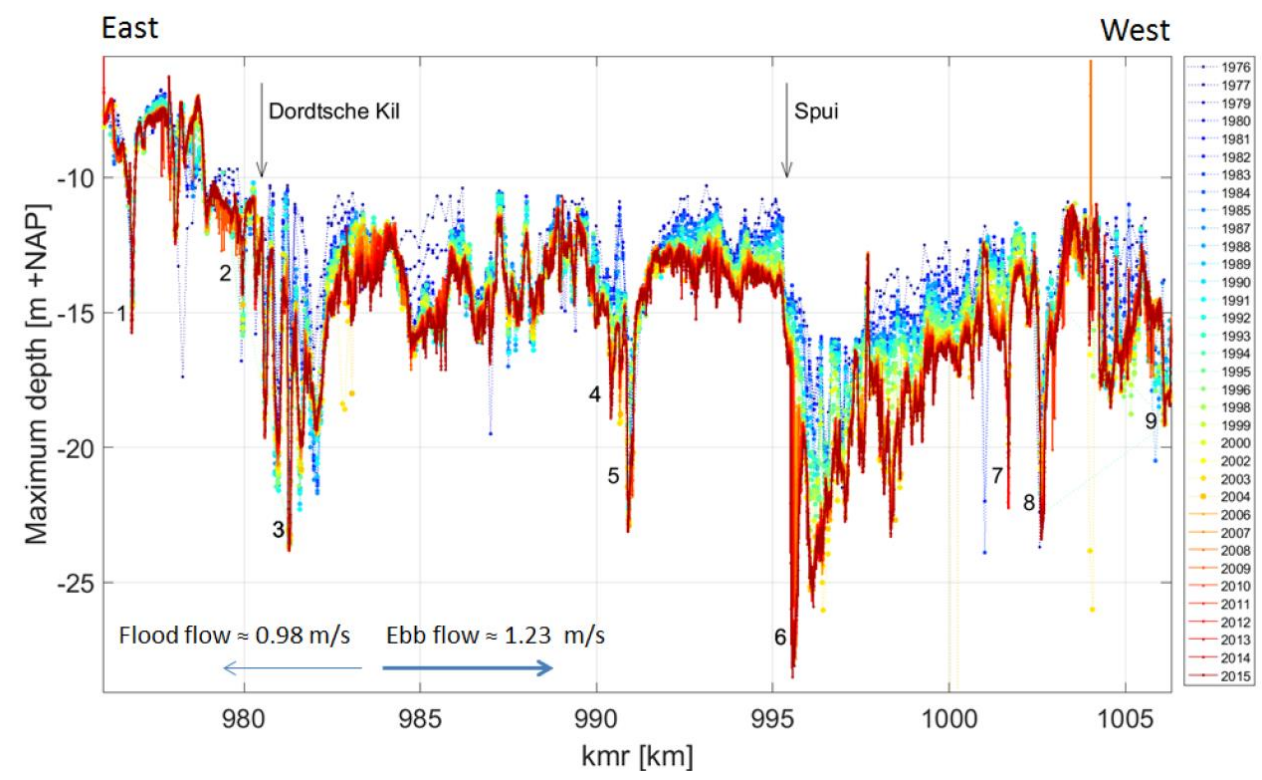

Figuur 34 Ontwikkeling maximale diepteligging tussen 1976-2015 langs de as van de rivier voor de Oude Maas. Bron: Koopmans (2017).

\subsubsection{Flankerende maatregelen}

Uit de analyse in §5.2.3.2 blijkt dat er sprake is van zandhonger in het Haringvliet en Hollands Diep, waarbij naar schatting het huidige sedimenttekort $1.10^{9} \mathrm{~m}^{3}$ bedraagt, ofwel $1.000 \mathrm{Mm}^{3}$. Bij de variant stormvloedkering is dit naar schatting $\sim 0,4 \cdot 10^{9} \mathrm{~m}^{3}$, ofwel $400 \mathrm{Mm}^{3}$. Ter vergelijking bedraagt het jaarlijkse suppletievolume voor de kust $12 \mathrm{Mm}^{3}$. Omdat het suppleren van deze hoeveelheden zand aanzienlijke kosten met zich mee brengt, zijn maatregelen gericht op het mitigeren van de negatieve gevolgen van zandhonger kostenefficiënter. Met betrekking tot de ecologische functie van het 
Haringvliet is het grootste nadeel van de zandhonger dat het plaatareaal met een gunstige droogvalduur voor bijvoorbeeld het foerageren door vogels afneemt. De platen vormen over het algemeen een belangrijk foerageergebied voor vogels en de foerageerfunctie wordt hierbij bepaald door het areaal intergetijdengebied en de droogvalduur als mate voor de voedselbeschikbaarheid en de foerageertijd (Van der Werf et al., 2015). Met lokale zandsuppleties kunnen de negatieve effecten van de plaaterosie worden beperkt doordat meer intergetijdengebied met juiste droogvalduur gecreëerd wordt. In 2008 heeft hier een succesvolle proef plaatsgevonden, waarbij $130.000 \mathrm{~m}^{3}$ sediment is gesuppleerd op de Galgenplaat in de Oosterschelde, zie Figuur 35. Deze suppletie blijkt relatief stabiel te zijn, waardoor er voldoende tijd is voor herstel van de benthische macrofauna, waar vogels van profiteren (Van der Werf et al., 2015). Naar aanleiding van deze proef is een ontwerp opgesteld voor een nieuwe suppletie uit te voeren op de Roggeplaat, welke naar verwachting in de winter van 2019 zal worden uitgevoerd. Deze suppletie zal 1,3 $\mathrm{M} \mathrm{m}^{3}$ bedragen, het tienvoudige van de Galgenplaat suppletie. Dit zou voldoende moeten zijn om voor de komende 25 jaar de huidige foerageerfunctie van het Roggenplaat/Neeltje Jans-complex te behouden. Doelindicator bij het ontwerp was hierbij het areaal dat 50-80\% van de tijd droogvalt (Van der Werf et al., 2016). De geschatte kosten voor deze suppletie bedragen 4-5 euro $\mathrm{m}^{-3}$.
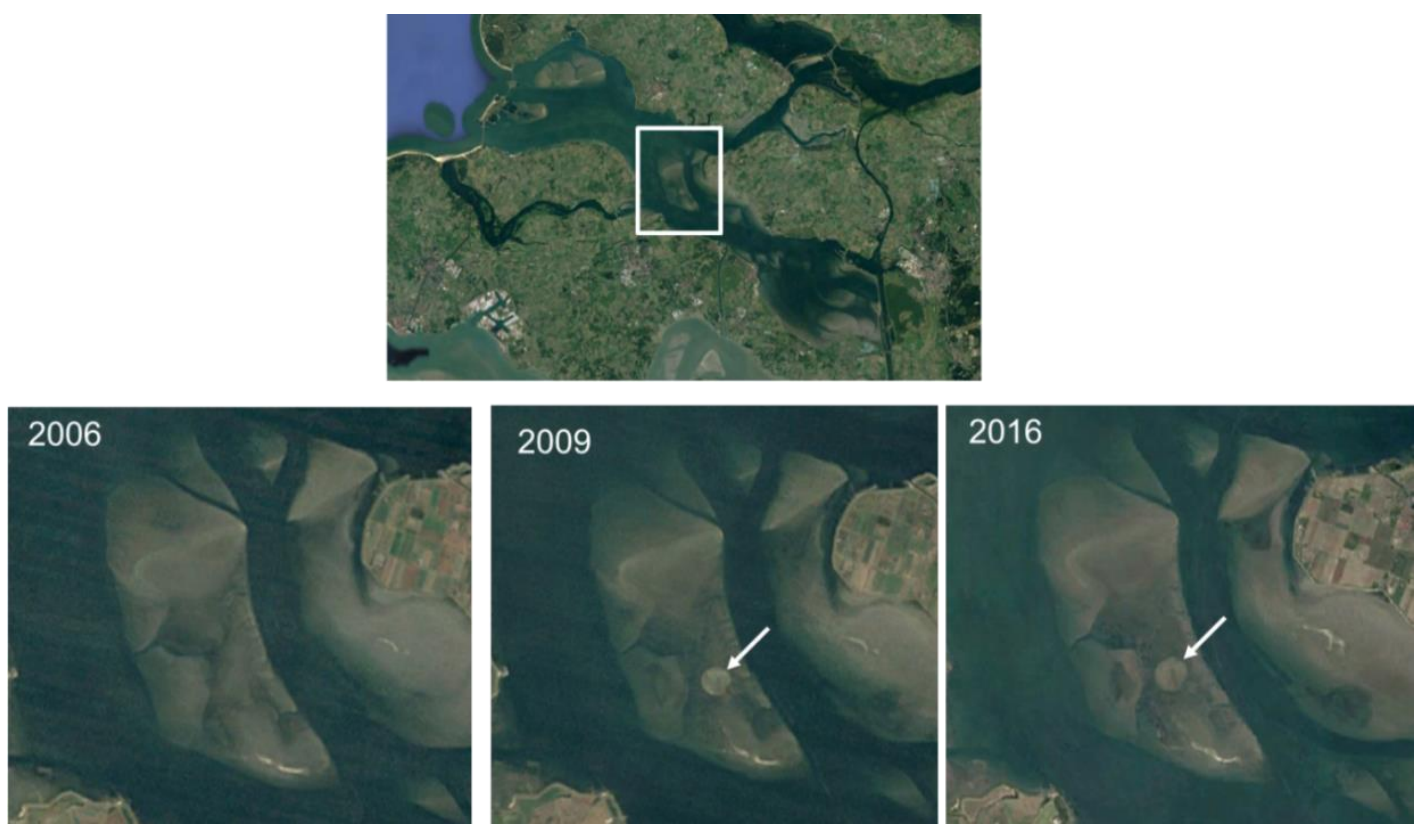

Figuur 35 Google Earth (c) satellietbeelden van de Galgenplaat in de Oosterschelde, voor (2006) en na (2009 en 2016) suppletie van $130.000 \mathrm{~m}^{3}$ in 2008.

\subsection{Buitendelta van het Haringvliet}

In de buitendelta van het Haringvliet vormen het Brielse Gat, de Hinderplaat en Garnalenplaten Noord en Zuid en de Kwade Hoek belangrijke gebieden voor de ecologie (Stam et al., 2002). De diverse platen vormen belangrijke intergetijdengebieden, het Brielse gat is onder meer een vogelrustgebied en de Kwade Hoek is eigendom van Natuurmonumenten. De locaties van deze gebieden en maatregelen zijn weergegeven in Figuur 36. 

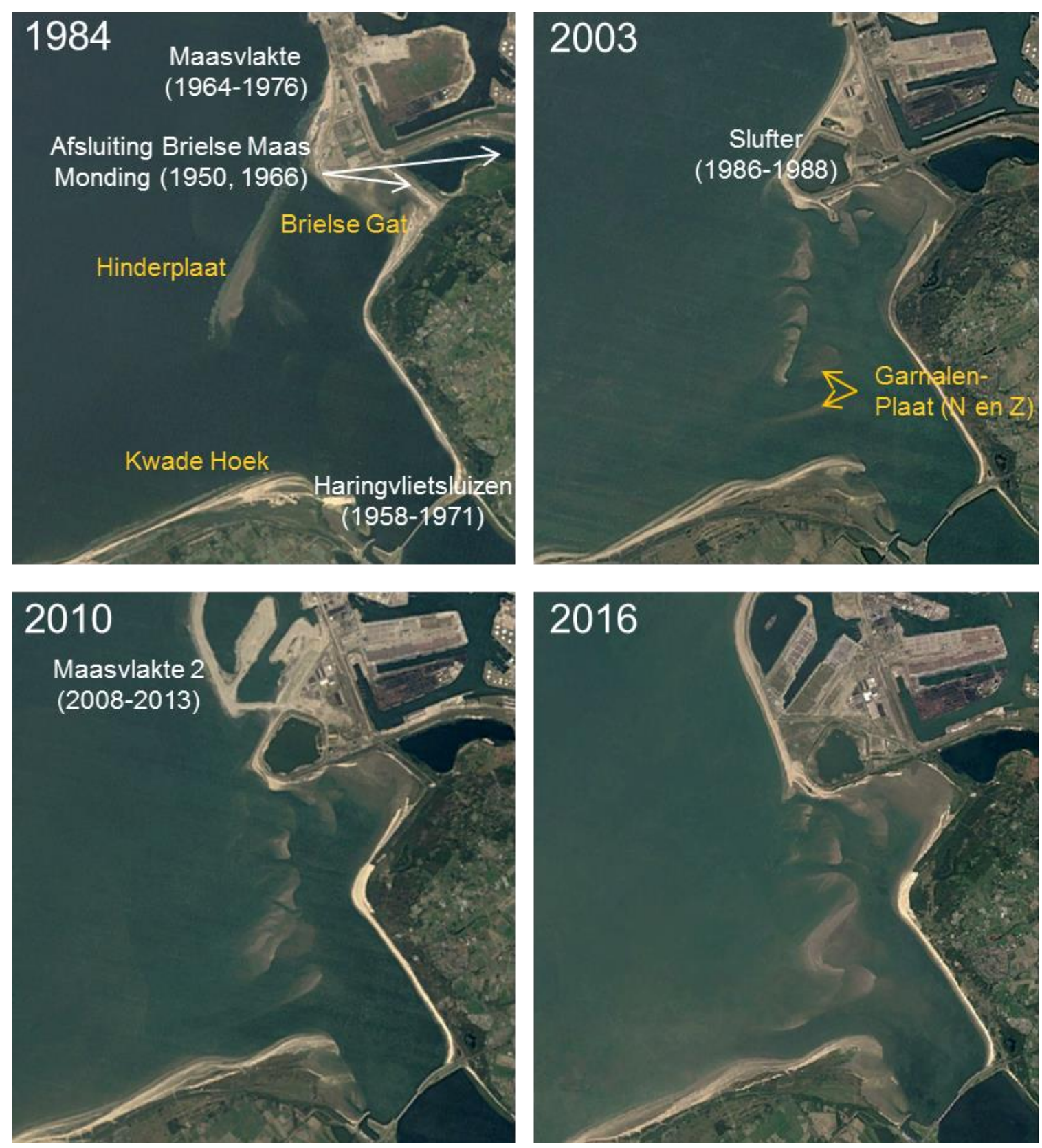

Figuur 36 Satellietbeelden van de buitendelta van het Haringvliet tussen 1984 - 2016 (Google Earth (C)), met daarop in geel de belangrijkste gebieden voor ecologie aangeduid en in wit de grootste ingrepen.

Sinds de jaren '50 van de vorige eeuw hebben er vele ingrepen plaatsgevonden die de buitendelta van het Haringvliet drastisch veranderd hebben(Elias et al., 2016):

1. Afsluiting Brielse Maas Monding met de Brielse Maasdam (1950) en de Brielse Gatdam (1966). Als gevolg hiervan trad aanzanding op van de Brielse Maas Monding en veranderden de geulen van de oriëntatie en groeiden platen samen;

2. Uitbreiding Rotterdamse Havengebied met onder andere de Maasvlakte (1964-1976), Slufterdam (1986-1988) en de Maasvlakte 2 (2008-2013). Hierdoor is de Haringvlietmonding steeds meer beschermd geraakt voor de noordwestelijke golfinvloed;

3. Bouw van de Haringvlietsluizen (1958-1971) en afsluiting van het Haringvliet. Hierdoor zijn de getijvolumes drastisch verkleind (van $530 \cdot 10^{6} \mathrm{~m}^{3}$ naar $20 \cdot 10^{6} \mathrm{~m}^{3}$, ter hoogte van de Haringvlietsluizen en van $730 \cdot 10^{6} \mathrm{~m}^{3}$ naar $230 \cdot 10^{6} \mathrm{~m}^{3}$ op de zeerand ${ }^{7}$ (Rijkswaterstaat, 1998a)) en de relatieve invloed van de golven toegenomen.

\footnotetext{
${ }^{7}$ Als zeerand is uitgegaan van de denkbeeldige lijn Goeree-Hinderplaat-Slufterdam.
} 
Een overzicht van de morfologische veranderingen die hierdoor zijn opgetreden tussen 1964 en 2009 zijn weergegeven in Figuur 37. Door de afname van de stroming door de sluizen, wordt er bijna geen sediment meer getransporteerd richting de buitendelta en domineert het golf gedreven zandtransport. Hierdoor is buitendelta landwaartse verschoven, wat te zien is aan de erosie in het zeewaartse gedeelte en sedimentatie in het landwaartse gedeelte (Figuur 37c). Door de afname van het getijvolume zijn daarbij de geulen aangezand en is het areaal intergetijdengebied toegenomen (Rijkswaterstaat, 1998a; Stam et al., 2002), zie Figuur 38 Voor 1964 waren twee getijgeulen aanwezig: Noord-Pampus in het zuiden, die overging in het Slijkgat, en Rak van Scheelhoek in het noorden welke opsplitste in het Bokkegat en het Gat van Hawk. Door de diverse ingrepen, is het Slijkgat nu de enige echte resterende getijgeul en zijn de overige geulen grotendeels aangezand (Rijkswaterstaat, 1998a; Stam et al., 2002; Elias et al., 2016).

Al voor de volledige afsluiting in 1971, moest voor de aanleg van de Haringvlietsluizen het Haringvliet gedeeltelijk worden afgesloten, waardoor het getijvolume afnam en de stroompatronen veranderden. Hierdoor transformeerde de Zeehondenplaat, met een loodrechte oriëntatie ten opzichte van de kust, in de Hinderplaat met een kust-parallelle oriëntatie (Elias et al., 2016). Na afsluiting is de Hinderplaat hoger en langer geworden (zie Figuur 36, beeld van 1984) en had het een beschermende werking voor het achterliggende gebied. Met de tijd is de plaat landwaartse verschoven en opgebroken (zie Figuur 36, beeld van 2003). In de huidige situatie is de Hinderplaat verder uitgespreid tot een waddenachtig gebied en is het niet langer herkenbaar als afzonderlijke plaat. De ontwikkelingen rond de Hinderplaat zijn vermoedelijk in belangrijke mate beïnvloed door de uitbreiding van het Rotterdamse Havengebied, waardoor dit gebied steeds meer afgeschermd is geraakt voor de noordwestelijke golfinvloed. De aanleg van Maasvlakte 2 heeft dit versterkt, met vermoedelijk de recente uitspreiding van de Hinderplaat tot waddenachtig gebied tot gevolg (Elias et al., 2016). Tot slot is de Kwade Hoek aangegroeid met vermoedelijk sediment uit de buitendelta van het Grevelingen, welke langs de kust wordt getransporteerd en wordt afgezet langs de kust van Goeree. 


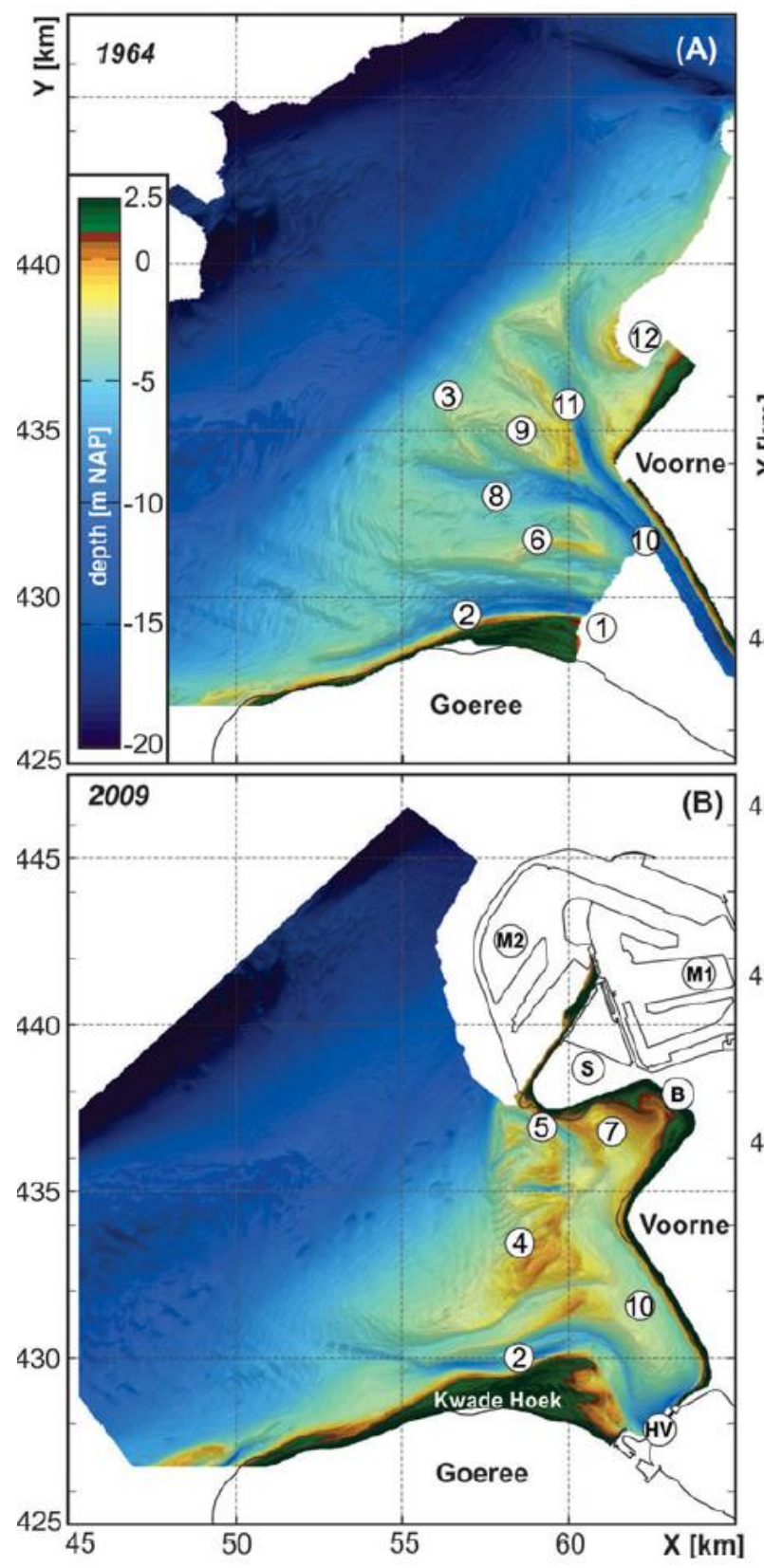

\begin{tabular}{|lc|}
\hline \multicolumn{2}{|l|}{ Main channels and shoals: } \\
\hline 1. Noord Pampus & 7. Brielse gat \\
2. Slijkgat & 8. Bokkegat \\
3. Hinder & 9. Zeehondenplaat \\
4. Hinderplaat & 10. Rak van Scheelhoek \\
5. Hindergat & 11. Gat van de Hawk \\
6. Garnalenplaat & 12. Westplaat \\
M1 : MaasVlakte 1 & \\
M2: Maas (1954-1970) \\
S : Slufter (1986-1988) \\
B : Brielse Gat Dam (1966) \\
HV : Haringvlietdam and -Sluices (1958-1971) \\
\hline
\end{tabular}
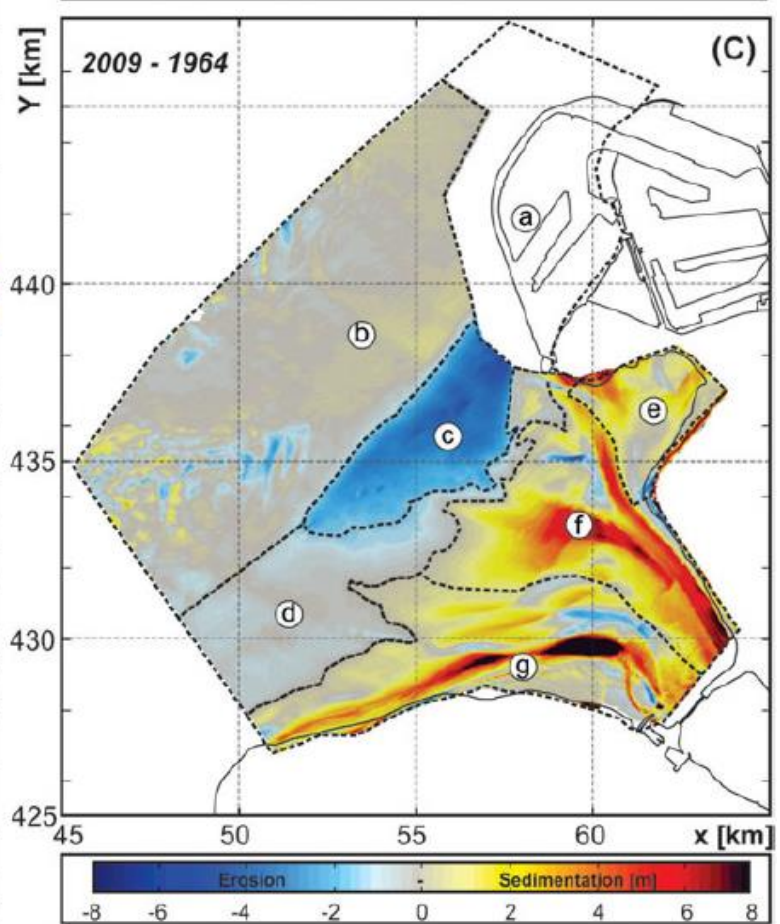

\begin{tabular}{|c|c|c|c|}
\hline \multicolumn{4}{|c|}{ Volume changes $1964-2009\left(\right.$ million $\left.\mathrm{m}^{3}\right)$ : } \\
\hline Location & Sed & Erosion & Net \\
\hline a. Maasvlakte2 & 14.7 & -337 & -18.5 \\
\hline b. Coast (offshore) & 5.8 & -20.3 & -14.5 \\
\hline c. Hinderplaat & 0.2 & -50.2 & -50.2 \\
\hline d. Coast (nearshore) & 0.0 & -15.4 & -15.0 \\
\hline e. Brielse Gat & 0.4 & -0.9 & 9.6 \\
\hline f. Scheelhoek & 10.5 & -2.2 & 64.5 \\
\hline g. Coast Goerree/Slijkgat & 66.6 & -4.4 & 50.2 \\
\hline Total & 98.2 & -127.1 & 26.1 \\
\hline
\end{tabular}

Figuur 37 Bodemtopografie van de buitendelta van het Haringvliet voor 1965 (A) en 2009 (B). De morfologische veranderingen tussen 1964-2006 zijn weergegeven in het sedimentatie-erosie figuur (C). Bron: Elias et al. (2016). 

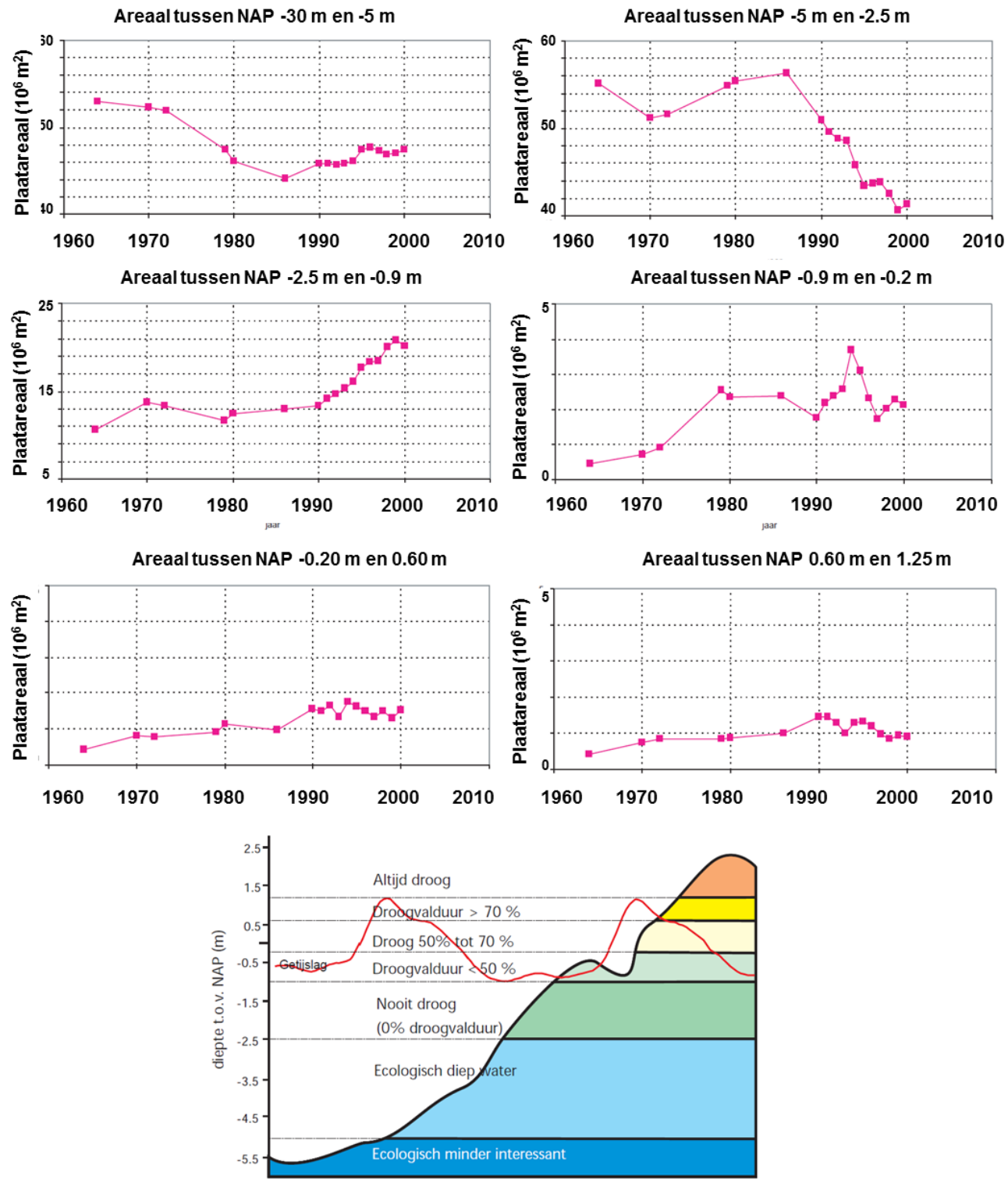

Figuur 38 Analyse ontwikkeling areaal intergetijdengebied van de Haringvliet buitendelta tussen 1963 en 2000, door Stam et al. (2002).

Uit de analyse van de historische ontwikkelingen blijkt dat de vele ingrepen samen de morfologie in de buitendelta sterk veranderd hebben. Zelfs wanneer de Haringvlietsluizen weer volledig geopend zullen worden (variant Stormvloedkering), zal de morfologie niet terug gebracht worden naar de situatie van voor de afsluiting. Dit wordt tevens beïnvloed door de aanwezigheid van de Haringvlietdam welke een blokkade blijft voor zowel de afvoer als sedimentuitwisseling tussen het binnen- en buitengebied. Gezien het Slijkgat de belangrijkste getijgeul is en het noordelijke deel van de buitendelta door de diverse ingrepen sterk is aangezand, zullen de veranderingen bij een ander beheer van de sluizen, waarschijnlijk het grootste zijn in het zuidelijke deel van de buitendelta. Door de toename van het getijvolume en de stroomsnelheden zullen de geulen of minder sterk aanzanden of gaan verruimen, afhankelijk van hoever ze nu van hun morfologisch evenwicht verwijderd zijn. Of de geulen in het noordelijke deel zich weer zullen openen is zeer de vraag, gezien dit deel door de diverse ingrepen sterk veranderd is van karakter. Tot slot zal naar verwachting erosie van slikken en platen optreden. Een gedetailleerder beeld van de verwachte erosie en sedimentatie kan verkregen worden uit $2 \mathrm{D}$ morfodynamische modellen.

Bovenop de lange-termijn teruggang van het areaal intergetijdengebied ten gevolge van de morfologische veranderingen, zal het areaal ook direct na opening afnemen door de reductie in getijslag ten gevolge van de grotere opening. Voor een kwantificering van met name de morfologische effecten is een uitgebreide analyse nodig. 


\section{$6 \quad$ Ecotopen}

\subsection{Indeling ecotopen}

Om tot een beoordeling te kunnen komen van de potentiële intergetijdengebieden die gaan ontstaan binnen het onderzoeksgebied als gevolg van het terugbrengen van het getij is een ecotopenindeling gemaakt. Deze ecotopenindeling is gebaseerd op de ecotopenindeling zoals die is gebruikt in de studie "Samenhang in de Delta" (Ysebaert et al., 2013a; Ysebaert et al., 2013b; Ysebaert et al., 2016). De ecotopenindeling is gebaseerd op hoogteligging van de bodem in relatie tot de getijstatistieken en het zoutgehalte. Doorgaans wordt er in de ecotopenclassificatie voor estuaria ook onderscheid gemaakt tussen hoogdynamische en laagdynamische ecotopen (Bouma et al., 2005). In de voorliggende studie is dit onderscheid niet gemaakt omdat (1) goede gegevens over de te verwachten morfo- en hydrodynamiek ontbreken en (2) het niet te verwachten is dat er hoogdynamische ecotopen (stroomsnelheden $>0,8 \mathrm{~m} \mathrm{~s}^{-1}$, megaribbels) zullen ontstaan in het onderzoeksgebied met de varianten die zijn doorgerekend.

\subsubsection{Hoogteligging}

De ecotopen zijn primair gebaseerd op de hoogteligging van de bodem in relatie tot de getijstatistieken (Figuur 39). Er zijn 7 gebieden onderscheiden op basis van de hoogteligging:

1. Diep water: Het Diep water is waar het water dieper is dan 5 meter beneden het gemiddeld laag water (GLW);

2. Ondiep water: Het Ondiep water is het gebied dat ligt tussen 5 tussen het gemiddeld laag water (GLW) en het Diep water;

3. Permanent intergetijdengebied: Het Permanent intergetijdengebied ligt tussen het gemiddeld laagwater (GLW) en het gemiddeld hoogwater tijdens de zomerperiode ( $\mathrm{GHW}_{\text {zomer}}$ ), waarbij de zomer is gedefinieerd als de periode tussen 1 april tot 1 september. Dit gebied valt regelmatig (vrijwel dagelijks) droog. Het kan gebeuren dat er, bijvoorbeeld tijdens stormopzet op de Noordzee één of meerdere getijden worden overgeslagen;

4. Zomer droog ${ }^{\mathbf{8}}$ : Het Zomer droog is het gebied tussen het gemiddeld hoog water in de zomer (GHWzomer) en het gemiddeld hoog water tijdens de winter (GHWwinter). Dit gebied valt tijdens de zomerperiode droog maar staat gedurende de winterperiode onder invloed van (dagelijks) getij;

5. Hoog intergetijdengebied: Het Hoog intergetijdengebied ligt tussen het gemiddeld hoogwater in de winter ( $\mathrm{GHW}_{\text {winter }}$ ) en het hoogwater tijdens springtij in de winter (HWS winter $_{\text {) }}$. Dit gebied staat maandelijks onder water maar valt ook regelmatig gedurende langere tijd droog;

6. Nat terrestrisch: Het Nat terrestrisch ligt boven de hoogwaterlijn tijdens springtij in de

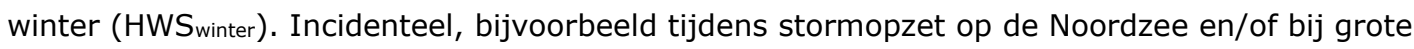
rivierafvoer kan dit gebied wel onder water komen te staan;

7. Droog terrestrisch: Het Droog terrestrisch ligt boven het maximale waterpeil, en komt dus niet onder water te staan als gevolg van extreem hoge waterstanden;

Het intergetijdengebied in een rivierengebied als Haringvliet, Hollands Diep en Biesbosch is vanwege de seizoensvariatie in rivierafvoer anders dan een intergetijdengebied in mariene systemen zoals de Ooster- en Westerschelde. Bij een lage middenstand kan het permanent intergetijdengebied in riviersystemen gedurende dagen tot weken droogvallen en bij een hoge middenstand kan het dagen tot weken overstroomd blijven. Dit is met name het geval in de variant Huidige situatie (en Kierbesluit) waar de variatie in de middenstand het grootst is. Deze ecotopen zijn kenmerkend voor getijdenrivieren. Binnen het ecotoop Permanent intergetijdengebied zouden sub-ecotopen kunnen

\footnotetext{
${ }^{8}$ In de zomerperiode zijn de waterstanden in het onderzoeksgebied over het algemeen lager dan in de winter als gevolg van de lagere rivierafvoer en minder stormopzet op de Noordzee tijdens de zomer.
} 
worden gemaakt van gebieden die langdurig droogvallen of langdurig onder water komen te staan. Dit is in de huidige studie niet gedaan.

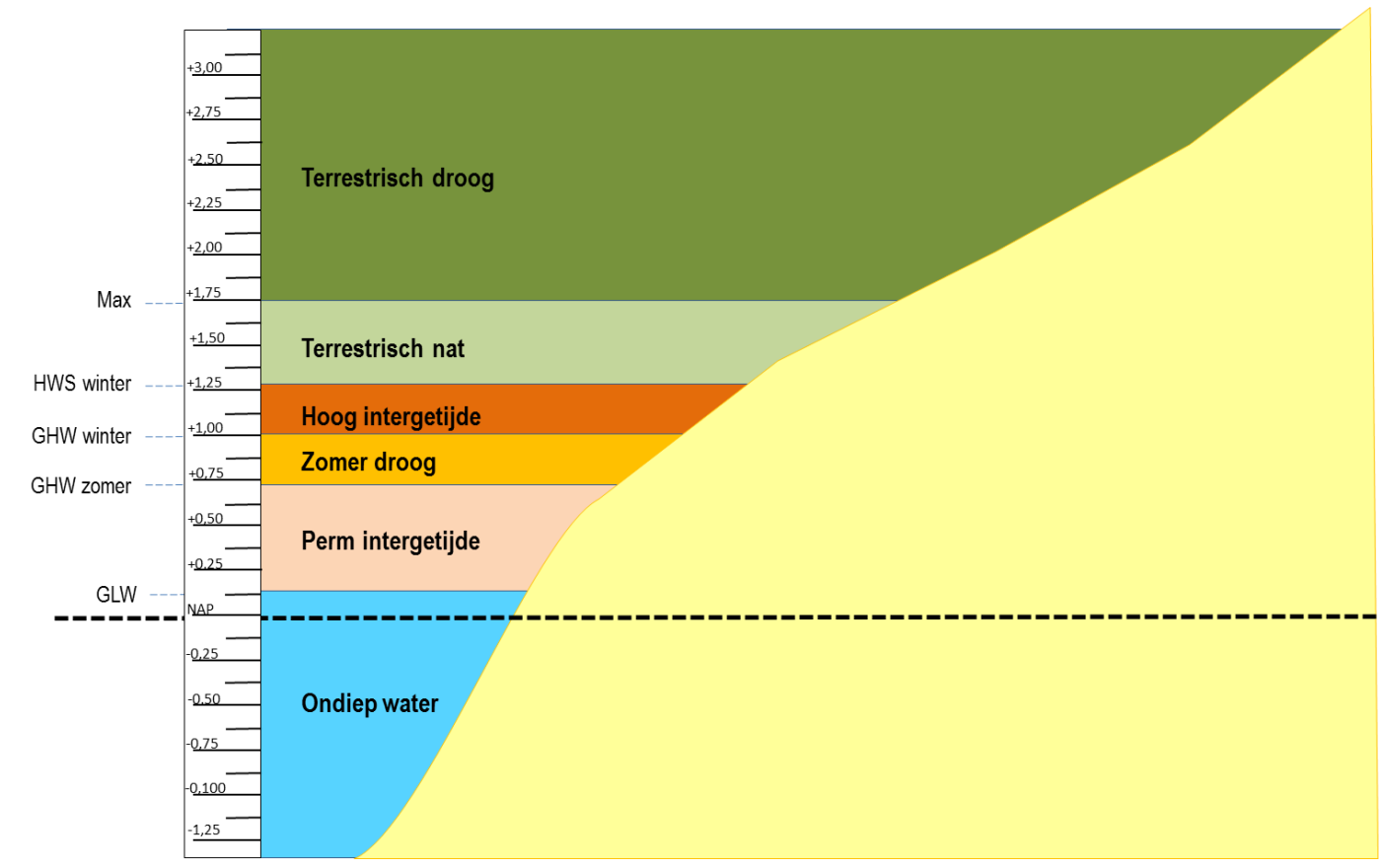

Figuur 39 Schematisch overzicht van de koppeling van de ecotopen aan de getijstatistieken.

Getijstatistieken in dit voorbeeld zijn bepaald uit de waterstanden van de locatie Deeneplaat

(Figuur 3) voor de variant Huidig beheer. Voor de overige varianten zijn de schema's weergeven in Bijlage 1.

\subsubsection{Zoutgehalte}

Zoutgehalte is een belangrijke factor voor het voorkomen van soorten en daarmee ook voor de kwaliteit van de ecotopen. Het leven in het zout water domein vraagt om specifieke fysiologische aanpassingen bij de betroffen organismen, onder andere met betrekking tot de water- en zouthuishouding, waardoor zoutwatersoorten zich onderscheiden van zoetwatersoorten. De overgangszone (brakwaterzone), waar zoet overgaat in zout en waar het zoutgehalte veelal grote variatie kent is van nature vaak soortenarm. Er zijn maar weinig soorten die zich kunnen handhaven in dit dynamische milieu zoals benadrukt door de relatie tussen diversiteit en zoutgehalte en weergegeven in de zogenaamde curve van Remane (1934) (Figuur 40). De brakwaterzone, gekenmerkt door een lage biodiversiteit, beslaat specifieke, en in de Nederlandse wateren zeldzaam geworden estuariene habitats met typische soorten die nergens anders te vinden zijn dan in deze zoet zout overgangen en daarmee leiden tot een verhoging van de uniciteit (Tangelder et al., 2012; Tangelder et al., 2017). 

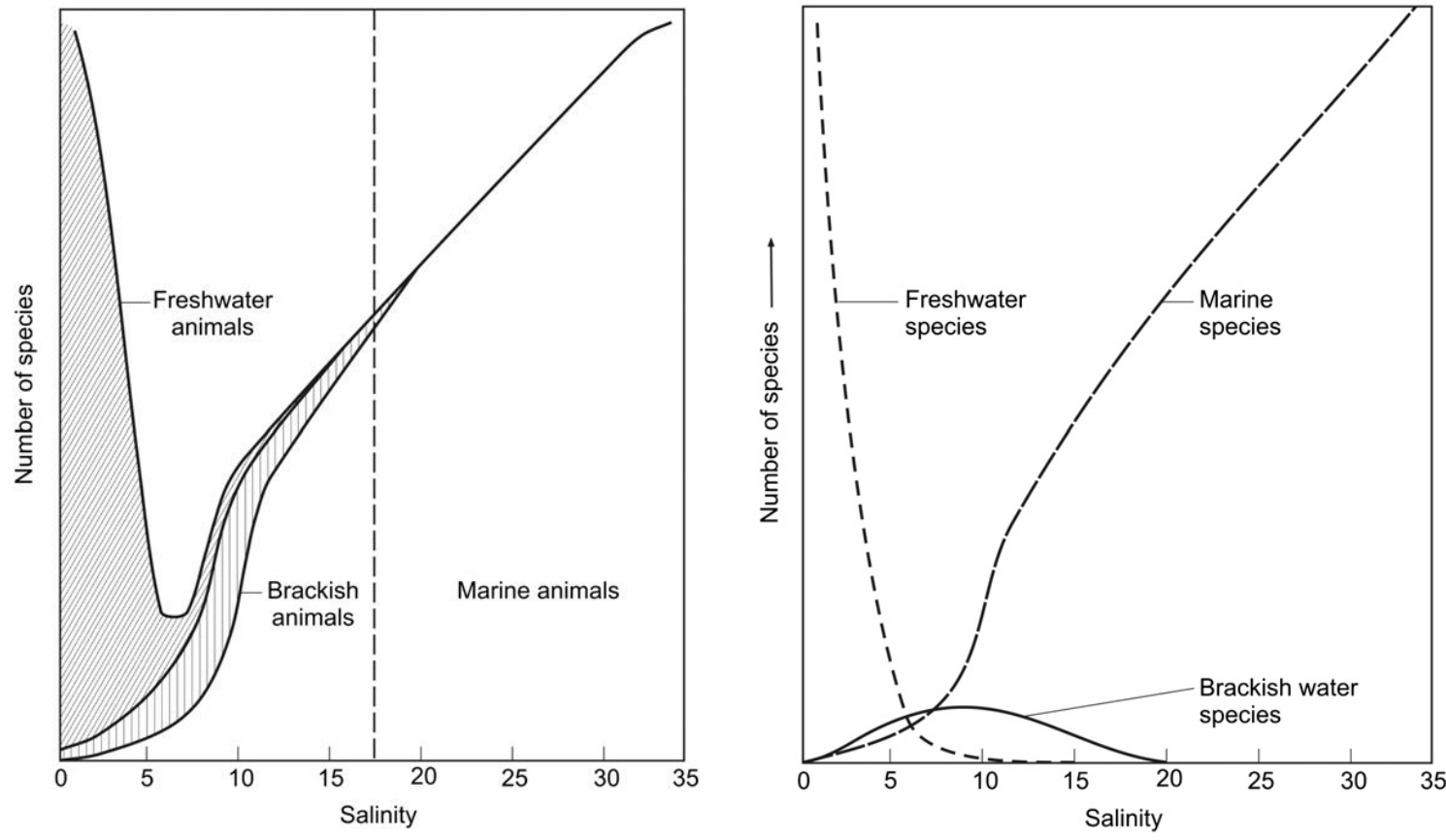

Figuur 40 Relatieve aantal zoet-, brak- en zoutwater diersoorten als functie van het zoutgehalte. In de linker figuur is het aantal soorten cumulatief uitgedrukt. De verticale stippellijn in de linker figuur geeft de verhouding $50 \%$ zoutwater en $50 \%$ zoetwater. Het minimum aantal soorten ligt bij een zoutgehalte tussen de 5 en 8 ppt (uit Whitfield et al., 2012).

Omdat estuaria in het algemeen zeer dynamische zoet-, brak- en zoutwatermilieus zijn met vele geleidelijke overgangen bestaat er een grote verscheidenheid aan habitats. Daarom is een natuurlijk estuarium, ondanks het beperkt aantal soorten die zich er kunnen handhaven toch een soortenrijk systeem (De Leeuw and Backx, 2000). In de overgang van zoet via brak naar zout komen daarom verschillende zoneringen van soortengemeenschappen voor. Figuur 41 illustreert de zonering van bodemdieren bij een natuurlijke zoet-zout overgang.

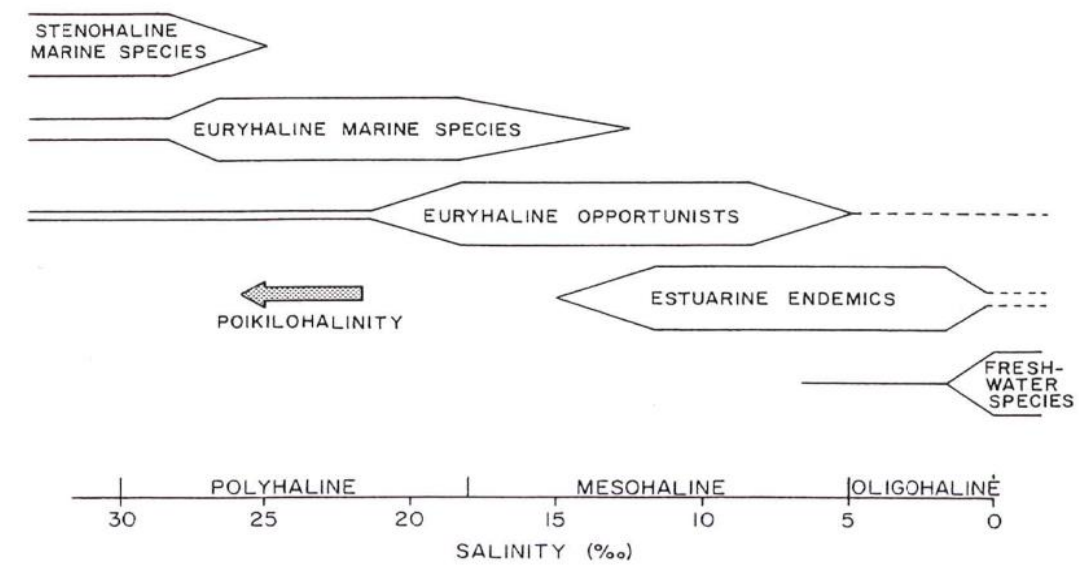

Figuur 41 Schematisch overzicht van de spreiding van benthische soortgroepen langs een geleidelijke zoutgradiënt in een estuarium (Boesch, 1977).

Op basis van zoutgehalte kunnen estuaria worden ingedeeld in een aantal zones (Ysebaert et al., 2013b)(Tabel 2). Zoetwater heeft een zoutgehalte van minder dan 0,5 ppt (of 0,3 $\mathrm{g} \mathrm{Cl} \mathrm{l}^{-1}$ ). De brakwaterzone loopt van 0,5 tot 18 ppt, waarbij de zone 0,5 tot 5,4 de oligohaliene zone is en de zone tussen 5,4 en 18 de mesohaliene zone. 


\begin{tabular}{llll} 
Tabel 2 & Indeling op basis van zoutgehalte (L\&O, 1958; Ysebaert et al \\
Zone & Zoutgehalte (ppt) & Zoutgehalte $\mathrm{g} \mathrm{Cl}^{-1}$ & Klasse \\
Zoetwater & $<0,5$ & $<0,3$ & Zoet \\
\hline Oligohalien & $0,5-5,4$ & $0,3-3$ & Brak \\
\hline Mesohalien & $5,4-18$ & $3-10$ & Brak \\
\hline Polyhalien & $18-30,6$ & $10-17$ & Zout \\
\hline Euryhalien & $>30,6$ & $>17$ & Zout \\
\hline
\end{tabular}

In delta's en estuaria wordt het zoet water van de rivier vermengd met het zout water van de zee. Hierdoor ontstaat er een gradiënt in zoutgehalte van de rivier naar de zee. Omdat zout water zwaarder is dan het zoet water van de rivieren kan er bij geringe getijdynamiek stratificatie ontstaan waarbij er een laag zoet water "drijft" op het zoute water. De mate van menging is van belang voor het al dan niet optreden van stratificatie. De mening in een estuarium wordt vooral bepaald door het getij (Baptist et al., 2007). Daar bovenop kunnen de rivieraanvoer en golven als gevolg van wind ook invloed uitoefenen. De ligging van de mengzone en de mate van verticale menging is afhankelijk van de rivierafvoer en van het getij.

Wolff (1973) heeft op basis van gegevens van de periode 1963 tot 1970 (voor de sluiting van de Haringvlietsluizen) kaarten gemaakt van de zoutgrenzen in het Deltagebied bij verschillende rivierafvoeren en waterstanden (Figuur 42). Ook in deze periode was het gebied al beïnvloed door aanleg van de Deltawerken. De Haringvlietdam is in 1971 opgeleverd, maar in 1958 en 1959 is de Hellegatsdam over de Ventjagersplaten al aangelegd waardoor de zoutdynamiek is beïnvloed in het gebied Haringvliet, Hollands Diep. In de figuur is duidelijk te zien dat de zout gradiënt in die periode zeer dynamisch was. Bij hoge rivierafvoer en laag water kwam het zoet water $\left(<0,3 \mathrm{~g} \mathrm{Cl} \mathrm{l}^{-1}\right)$ tot bij Hellevoetsluis. Tijdens hoogwater op de Noordzee bij een lage rivierafvoer kwam deze grens tot in de Biesbosch. Het effect van getij op de ligging van de $0,3 \mathrm{~g} \mathrm{Cl}^{-1}$ grens bij een gemiddelde rivierafvoer was beperkt. Tijdens hoogwater op de Noordzee lag de grens net ten oosten van Willemstad en tijdens laagwater lag deze grens net ten westen van Willemstad.
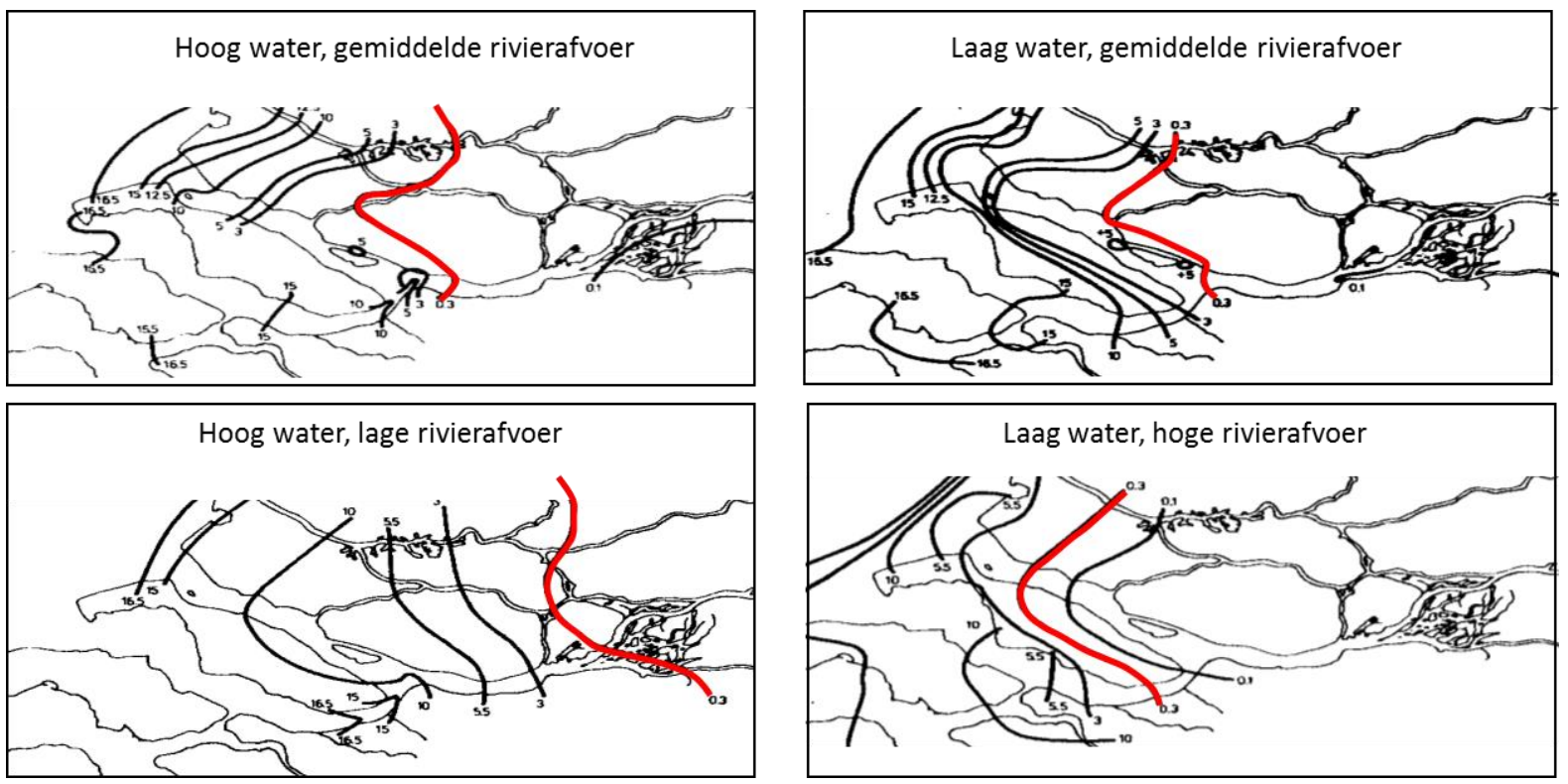

Figuur 42 Zoutgehalte bij de bodem in het onderzoeksgebied voor de sluiting van de Haringvlietdam bij verschillende rivierafvoeren en getijden. De rode lijn geeft de $0,3 \mathrm{~g} \mathrm{Cl} \mathrm{l}^{-1}$ isocline. Figuren komen uit Wolff (1973) en zijn gebaseerd op data uit 1963 tot 1970.

In deze studie zijn de grenzen tussen zoet en brakwater (oligohalien) voor de verschillende varianten gebaseerd op deskundigen-oordeel (zie §4.5). De zoutindringing is niet goed te modelleren met het $1 \mathrm{D}$ model dat is gebruikt in deze studie (§4.5.1), en momenteel is het 3D model voor de zoutverspreiding nog in ontwikkeling (Thiessen et al., 2017). Voor de ecotopenkaarten is de verwachte $0,3 \mathrm{~g} \mathrm{Cl} \mathrm{l}^{-1}$ ( 0,5 ppt) grens bij hoogwater tijdens normale afvoer gebruikt. Deze grens is ten behoeve van deze studie ingeschat op basis van deskundigen-oordeel, waarbij het midden van de 
ingeschatte bandbreedte als uitgangspunt voor de ecotopenmodellering is genomen (Figuur 13 tot en met Figuur 17 in §4.5). In het gebied ten westen van deze lijn zal bij normale rivierafvoer het zoutgehalte fluctueren tussen brak en zoet als gevolg van het getij, en daardoor meer kenmerkend zijn voor een brakwater zone. Een overzicht van de grenzen die in de ecotopenmodellering zijn gebruikt om het verschil tussen brakke en zoete ecotopen te duiden is weergegeven in Figuur 43.

Bij de inschatting van de zoutgrens voor de variant Huidig beheer is het hele modelgebied overwegend zoet. Na de invoering van het Kierbesluit wordt aangenomen dat de brakwaterzone gaat toenemen tot maximaal de lijn Spui - Middelharnis. In het geval van de variant $80 \mathrm{~cm}$ getij is er voor de ecotopenkaarten gekozen om de brakwaterzone tot Tiengemeten te laten komen (zie ook §4.5.4). Voor de variant Stormvloedkering is ervoor gekozen om de brakwaterzone tot aan de Haringvlietbrug te laten komen (zie ook §4.5.3). Dit is iets minder ver dan de situatie van een gemiddelde rivierafvoer uit Wolff (1973). Voor het klimaatscenario ten slotte is ervoor gekozen om de brakwaterzone tot in het Hollands Diep te laten komen (zie ook §4.5.5). De gebruikte grenzen zijn statisch. In werkelijkheid zullen deze grenzen, net als vroeger het geval was, ten gevolge van getij en rivierafvoer continue bewegen. Zo kan het gebeuren dat de zoete zones tijdelijk oligohalien worden tijdens lage rivierafvoer en de oligohaliene zones tijdelijk zoet tijdens hoge rivierafvoer.

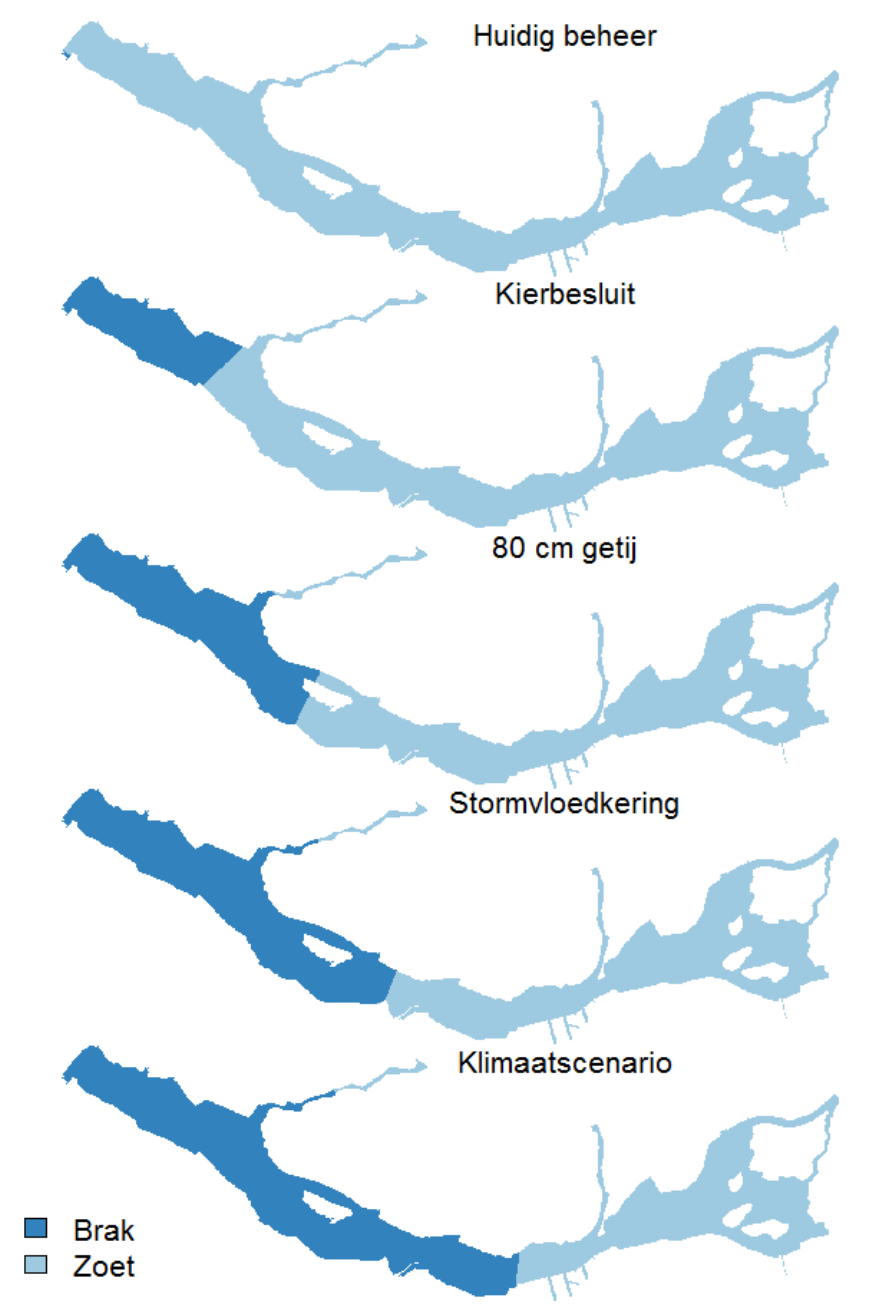

Figuur 43 Ligging van de zoutgrenzen zoals ze zijn gebruikt in deze studie. Brakwater is hierbij gedefinieerd als $>0,5 \mathrm{ppt} \sim 0,3 \mathrm{~g} \mathrm{Cl} \mathrm{l}^{-1}$.. De zoutgrenzen voor de verschillende varianten zijn gebaseerd op deskundigen-oordeel met een aanzienlijke geografische bandbreedte. Ten behoeve van de ecotopenmodellering is het midden van de bandbreedte als uitgangspunt genomen (zie $\S 4.5)$. 


\subsubsection{Ecotopen}

De 7 ecotopen die zijn gebaseerd op de hoogteligging en waterstandsfluctuaties zijn op basis van de zoutkaarten (Figuur 43) onderverdeeld in een zoete variant (zoutgehalte $<0,5 \mathrm{ppt}$ ) en een brakke variant (zoutgehalte $>0,5 \mathrm{ppt}$ ). Hierdoor zijn er in totaal 14 ecotopen. In de figuren hebben de ecotopen ieder een andere kleur gekregen (Figuur 44). De blauwe kleuren zijn de sublitorale ecotopen. De roze tot bruine kleuren geven de intergetijdengebieden en de groene kleuren geven de terrestrische gebieden.

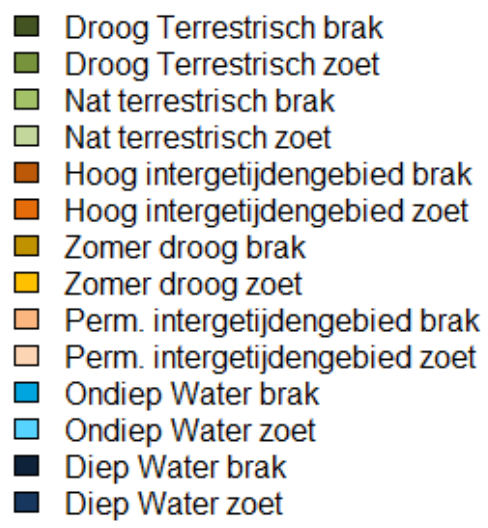

Figuur 44 Kleurcoderingen van de verschillende ecotopen zoals ze zijn gebruikt in dit rapport.

\subsection{Berekening ecotopen}

\subsubsection{Bathymetrie}

De dieptekaart (Figuur 3) die in deze studie is gebruikt is gebaseerd op de kaart die gebruikt is in de studie "Samenhang in de delta" (Ysebaert et al., 2013a; Ysebaert et al., 2013b; Ysebaert et al., 2016). Deze studie is in 2013 door Wageningen Marine Research en Deltares uitgevoerd in opdracht van het Planbureau voor de Leefomgeving (PBL). Doel van die studie was om een lange termijn ontwikkel perspectief te geven voor de gehele Zuidwestelijke Delta. De dieptegegevens voor de deelgebieden Haringvliet, Hollands Diep, Biesbosch, Spui en Dordtsche Kil zijn destijds aangeleverd door Deltares (Ysebaert et al., 2013a). In deze kaart waren de gebieden Tiengemeten, Noordwaard, en ook de drie bekkens in de Biesbosch (De Gijster, Honderd en Dertig en Petrusplaat) niet meegenomen. Voor de voorliggende studie is de dieptekaart uit de studie "Samenhang in de Delta" op twee punten aangepast. Het gebied Leenheerenpolder is verwijderd omdat deze omdijkt is. Het getij kan niet zondermeer het gebied binnendringen. Tevens is er een deel van Tiengemeten (Brienenswaard en Mariapolder) toegevoegd aan het modelgebied (Posthoorn, 2002; De Bruijn and Van Der Zanden, 2011). De resolutie van de diepte kaart is $20 \times 20$ meter.

\subsubsection{Waterstanden en statistieken}

Voor 7 locaties binnen het modelgebied (Hellevoetsluis, Middelharnis, Bernisse/Zuidland, Rak Noord, Moerdijk, Deeneplaat en Gat van Kampen Figuur 3) zijn iedere 10 minuten voor een periode van 10 jaar (1996 tot en met 2006) de waterstanden berekend met het 1D model (zie §4.1). In Figuur 61 is een voorbeeld gegeven voor de resultaten van de locatie Hellevoetsluis voor het huidig beheer. De resultaten van de overige varianten zijn te vinden in Bijlage 6. 


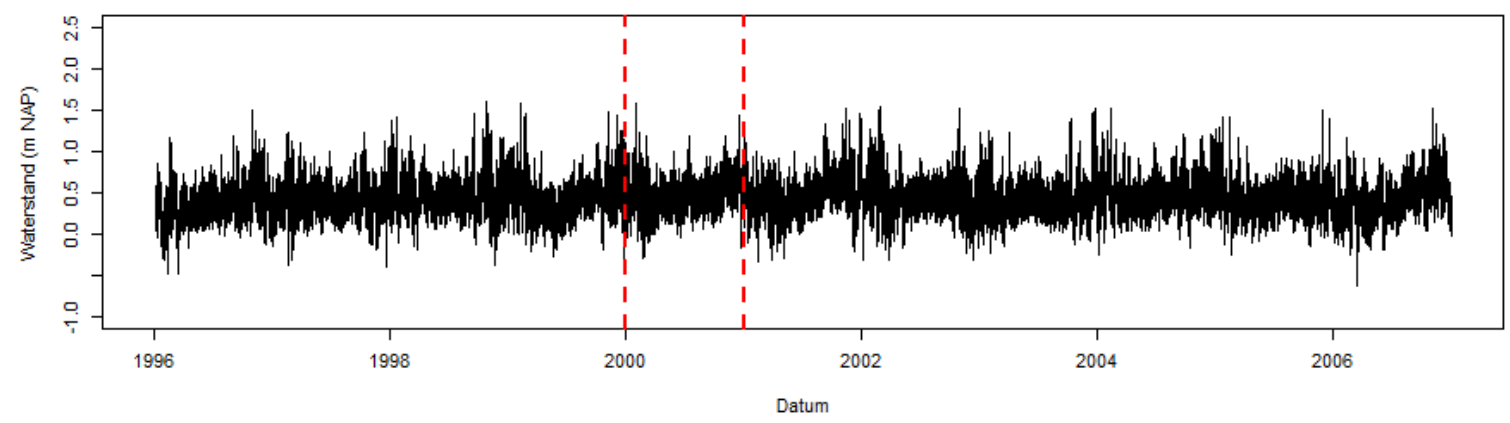

Waterstanden Variant: Huidig beheer Locatie: HLVTSLS in het jaar 2000

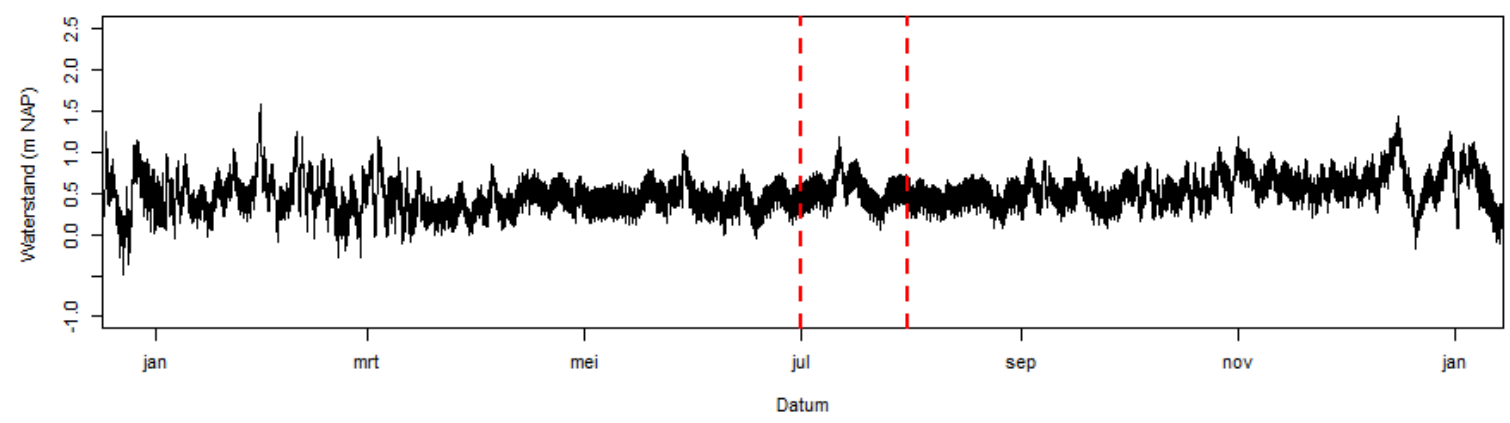

Waterstanden Variant: Huidig beheer Locatie: HLVTSLS voor Jul 2000

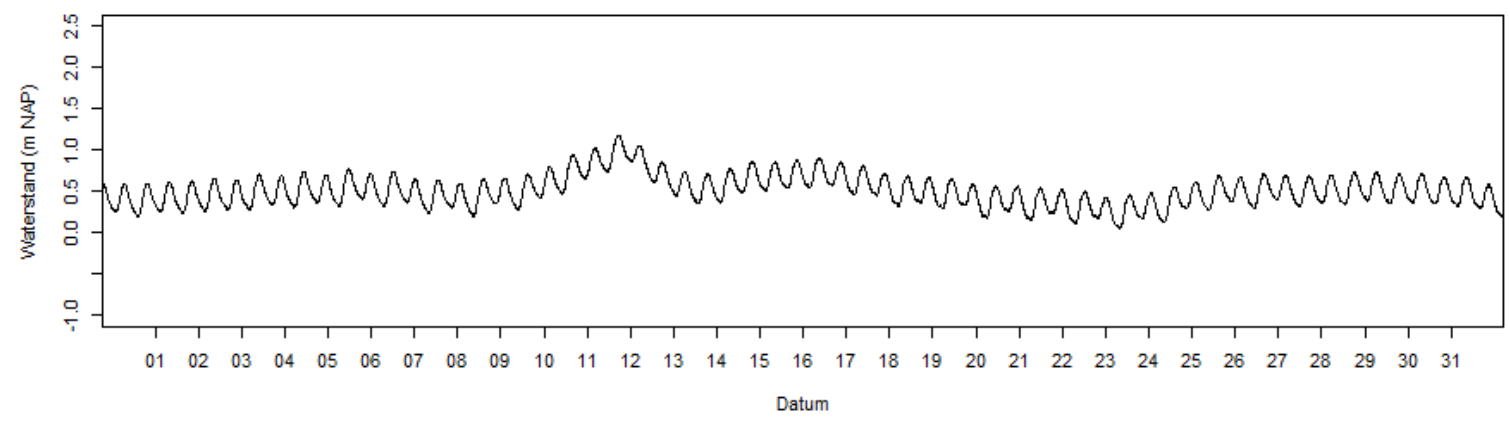

Figuur 45 Berekende waterstanden voor de locatie Hellevoetsluis voor de variant Huidig beheer voor de hele periode (bovenste figuur), het jaar 2000 (middelste figuur) en de maand Juli in 2000 (onderste figuur).

In Figuur 45 is de invloed van het dagelijks getij duidelijk te zien (onderste paneel). Tevens is te zien dat het gemiddeld peilniveau kan fluctueren als gevolg van windopzet maar ook rivierafvoer. Als het peil op de Noordzee tijdens laagwater te hoog is als gevolg van een noordwesterstorm kan er geen water worden afgevoerd. In de bovenste twee panelen van Figuur 45 is te zien dat de fluctuaties in de "winterperiode" ( 1 september tot 1 april) groter zijn dan tijdens de "zomerperiode" (1 april tot 1 september).

Voor alle monitoringslocaties (Figuur 3) zijn de getijstatistieken bepaald uit de met het 1D model berekende waterstanden. Naast de maximale waterstand (maximale waarde van alle berekende waterstanden over de periode van 10 jaar) is gebruik gemaakt van de percentielwaarden ${ }^{9}$ van de berekende waterstanden. Het gemiddeld laagwater (GLW) is hierbij gedefinieerd als het 5-percentiel van de waterstanden over de gehele periode. GHW zomer en $\mathrm{GHW}_{\text {winter }}$ zijn de 95-percentielen van de waterstanden tijdens respectievelijk de zomerperioden ( 1 april tot 1 september) en de winterperioden (1 september tot 1 april). Hoogwater tijdens springtij ( HWS $_{\text {winter }}$ ) is het 99-percentiel van de waterstanden tijdens de winterperioden. Ten slotte is de maximale waterstand bepaald voor elke locatie.

\footnotetext{
${ }^{9}$ Het x-percentiel van een verdeling is de waarde in de verdeling waaronder $\mathrm{x}$ procent van de waarnemingen valt.
} 
Het gebruik van percentielen is een benadering om de getijstatistieken (GHW, GLW, etc.) te benaderen. Dit werkt over het algemeen goed voor gebieden waar de waterstand hoofdzakelijk wordt bepaald die door het getij (en eventueel windopzet). In het onderzoeksgebied wordt de waterstand echter niet alleen bepaald door het getij maar ook door de veranderende middenstand als gevolge van de variërende rivierafvoer. Om een indruk te krijgen in de bruikbaarheid van de in deze studie gehanteerde methode om getijstatistieken af te leiden van de berekende waterstanden is in Tabel 3 voor de zomer- en de winterperiode, het verschil tussen het via de percentielen berekende GHW en GLW (intergetijdengebied) en de gemiddelde getijslag over een periode van 24 uur en 50 minuten (zie §4.3). In de zomerperiode lijkt er een redelijke overeenkomst te zijn tussen beide berekeningen. Het grootste verschil $(16 \mathrm{~cm})$ treedt op in de variant Huidig beheer, maar bij de overige varianten is dit verschil minder van $5 \mathrm{~cm}$. In de winterperiode zijn de verschillen groter. Het maximale verschil is 37 $\mathrm{cm}$ bij de variant Huidig beheer en neemt geleidelijk af naar $10 \mathrm{~cm}$ verschil bij de variant Klimaatscenario. Een overschatting van het de dagelijkse getijslag in de zomer leidt tot een overschatting van het areaal permanent intergetijdengebied en een onderschatting van het areaal Zomer droog. De grotere verschillen in de winterperiode hebben waarschijnlijk te maken met de meer variërende middenstand als gevolg van de variatie in rivierafvoer (en stormopzet) tijdens de winter.

Tabel 3 Getijslag $(\mathrm{m})$ en het verschil tussen Gemiddeld Hoog Water en Gemiddeld Laag Water $(\mathrm{m})$ berekend uit de percentielen voor de locatie Hellevoetsluis in de zomerperiode en de winterperiode.

\begin{tabular}{l|cc|cc|}
\hline & \multicolumn{3}{|c|}{ Zomer } & \multicolumn{2}{c|}{ Winter } \\
\hline Huidig beheer & Getijslag & GHW-GLW & Getijslag & GHW-GLW \\
\hline $80 \mathrm{~cm}$ getij & 0,43 & 0,59 & 0,51 & 0,88 \\
\hline Stormvloedkering & 0,78 & 0,83 & 0,82 & 1,15 \\
\hline Klimaatscenario & 1,28 & 1,27 & 1,33 & 1,48 \\
\hline
\end{tabular}

\subsection{Ecotopenkaarten en arealen}

\subsubsection{Ecotopenkaarten}

In Figuur 46 zijn de ecotopenkaarten voor de verschillende varianten weergegeven voor het hele modelgebied. In Bijlage 7 (Deelgebied Haringvliet west), Bijlage 8 (Deelgebied Tiengemeten) en Bijlage 9 (Deelgebied Biesbosch) zijn detailuitsneden gemaakt voor een drietal deelgebieden. De potentiële intergetijdengebieden bevinden zich voornamelijk in het Haringvliet en de Biesbosch. Het verschil tussen de variant Huidig beheer en Kierbesluit is alleen zichtbaar in de zoutgrens, die zich in de variant Kierbesluit in de buurt van Middelharnis bevindt. De varianten $80 \mathrm{~cm}$ getij en Stormvloedkering leiden tot een toename van het intergetijdengebied. De variant Klimaatscenario leidt niet alleen tot een vergroting van de getijslag maar ook tot een verhoging van de middenstand. Dit leidt tot een toename in het ecotoop "Permanent intergetijdengebied" ten opzichte van de variant Huidig beheer. Echter de diversiteit aan ecotopen neemt af doordat de ecotopen "Zomer droog", "Hoog intergetijdengebied", alsmede de Terrestrische ecotopen in omvang afnemen.

In het Haringvliet (Figuur 66 en Figuur 67, Bijlage 7) zijn de grootste veranderingen de overgang van zoetwater in de variant Huidig beheer naar deels brak (varianten Kierbesluit en $80 \mathrm{~cm}$ getij) en volledig brak (varianten Stromvloedkering en Klimaatscenario). Bij de variant Kierbesluit ligt de trens ongeveer bij Middelharnis. Bij $80 \mathrm{~cm}$ getij ligt de zoutgrens ongeveer bij Tiengemeten, waardoor er rond het eiland zowel brakke als zoete ecotopen zijn te verwachten. In de varianten Stormvloedkering en Klimaatscenario is heel het Haringvliet brak. Als gevolg van de toename in getijamplitude wordt de Slijkplaat groter en nemen ook de Ventjagersplaten in het oostelijk deel van het Haringvliet in omvang toe. Op en rond het eiland Tiengemeten (Figuur 67, Bijlage 7) is te zien dat, als gevolg van de toename in het getijamplitude in de varianten $80 \mathrm{~cm}$ getij en Stormvloedkering, een deel van de terrestrische ecotopen aan de westen zuidwestzijde onder invloed komt te staan van getij tijdens de winterperiode. 
In de Biesbosch (Figuur 68, Bijlage 7) komt er een groot deel van het gebied dat in de variant Huidig beheer 's zomers droog is onder invloed van permanent getij te staan bij de varianten $80 \mathrm{~cm}$ getij en Stormvloedkering. De diversiteit aan ecotopen neemt hierdoor af in de Biesbosch. De variant Klimaatscenario leidt over het algemeen tot een verlaagde diversiteit aan ecotopen binnen het onderzoeksgebied. De Korendijkse slikken en Beningerslikken in het Haringvliet komen onder permanent getij te staan terwijl deze slikken in de varianten $80 \mathrm{~cm}$ getij en Stormvloedkering nog een uitgebreide arealen van de intergetijden-ecotopen "Zomer droog" en Hoog intergetijdengebied bevatten. Ook rond Tiengemeten is er bij de variant Stormvloedkering sprake van een vermindering van de diversiteit aan ecotopen. 


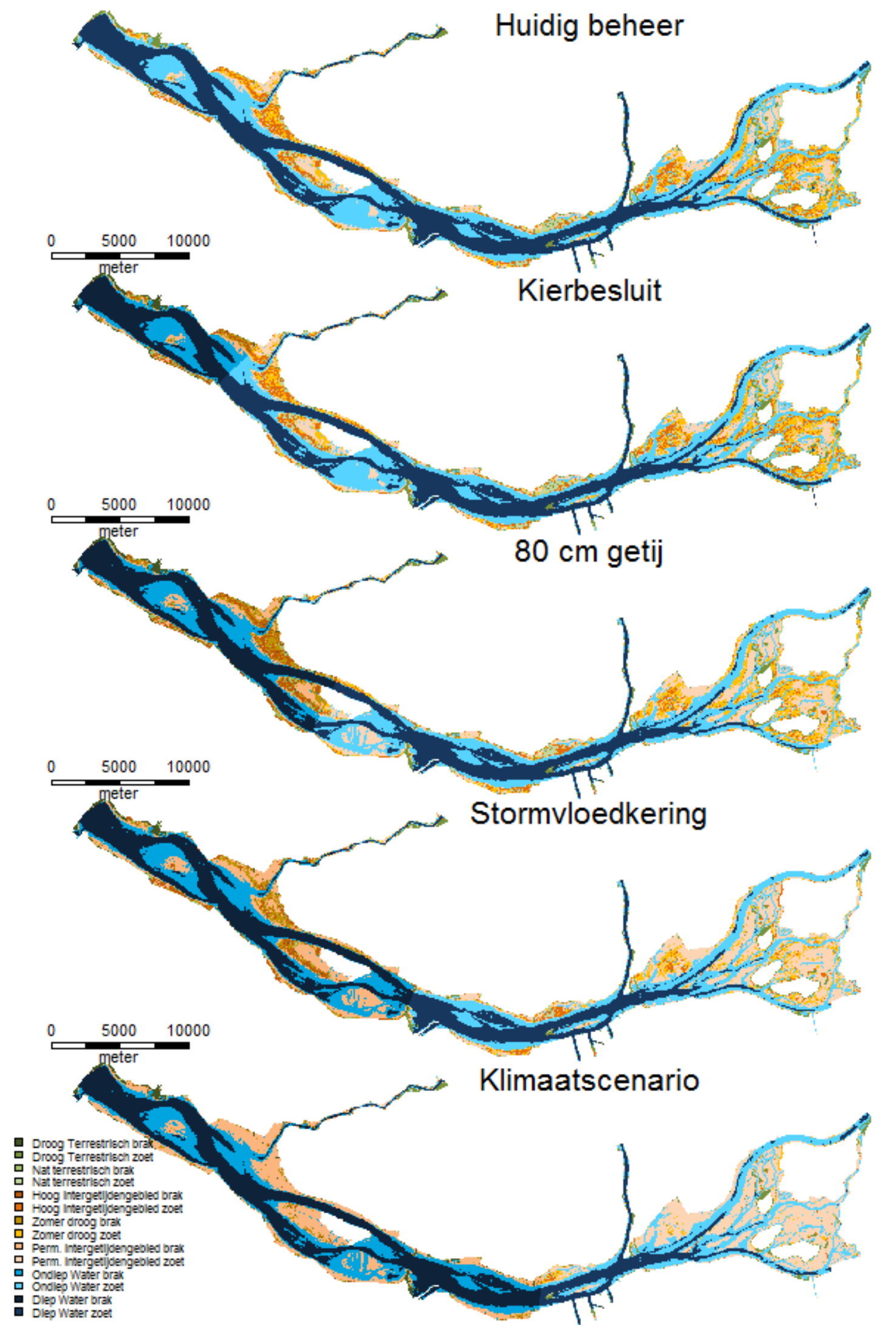

Figuur 46 Ligging van de ecotopen binnen het volledige modelgebied voor de varianten Huidig beheer, Kierbesluit, $80 \mathrm{~cm}$ getij, Stormvloedkering en Klimaatscenario. Voor meer informatie zie Bijlage 7 tot en met Bijlage 9.

In Figuur 47 is voor de varianten Kierbesluit, $80 \mathrm{~cm}$ getij, Stormvloedkering en Klimaatscenario aangegeven waar potentiële intergetijdengebieden kunnen ontstaan ten opzichte van de variant Huidig beheer. Deze gebieden zijn in de Huidige situatie dus ofwel sublitoraal ofwel terrestrisch. In Figuur 74 
en Figuur 75 (detailuitsnede oostelijk deel Haringvliet) van Bijlage 11 is te zien waar het potentieel nieuwe intergetijdengebied voor in de plaats komt (terrestrisch dan wel open water in de huidige situatie). Omdat de waterstandsfluctuaties bij de variant Kierbesluit identiek is aan de variant Huidig beheer is er bij deze variant geen sprake van nieuwe intergetijdengebieden.
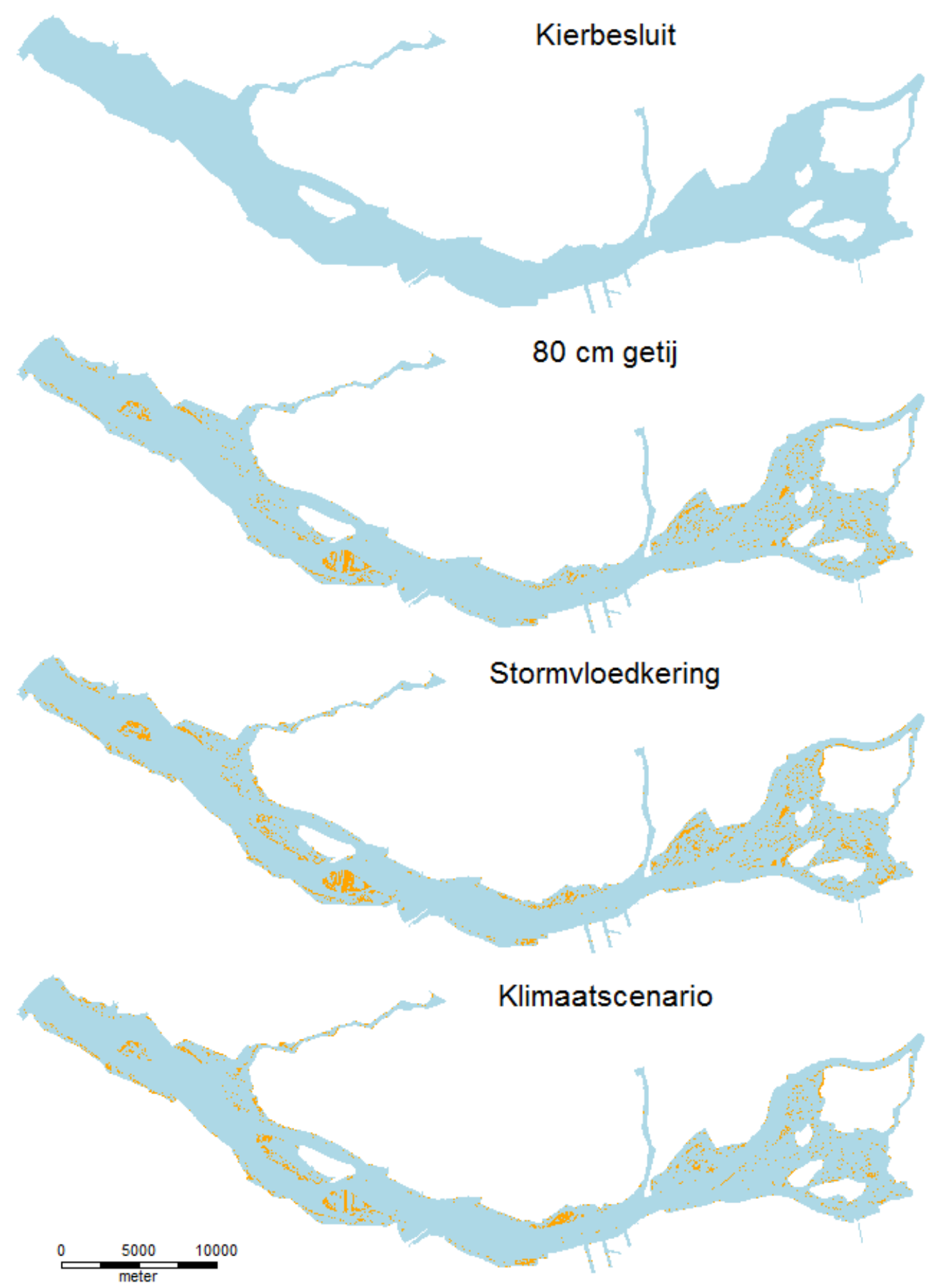

Figuur 47 Verschilkaarten van de intergetijdengebieden (variant - Huidig beheer). In oranje is aangegeven waar nieuwe arealen intergetijdengebieden (Permanent intergetijdengebied, Zomer droog en Hoog intergetijdengebied) ontstaan in het geval van de respectievelijk de varianten Kierbesluit $80 \mathrm{~cm}$ getij, Stormvloedkering en Klimaatscenario ten opzichte van de variant Huidig beheer.

Nieuwe potentiële intergetijdengebieden ontstaan in het Haringvliet bij de varianten $80 \mathrm{~cm}$ getij, Stormvloedkering en Klimaatscenario voornamelijk rond de Slijkplaat en de Ventejagersplaten. In de variant Huidig beheer is dit nog voornamelijk sublitoraal. Als gevolg van de grotere getijslag vallen deze gebieden tijdens laag water op de Noordzee droog. Bij de variant Klimaatscenario verdwijnen delen van deze potentiële intergetijdengebieden weer omdat ze, als gevolg van de stijgende water, niet meer droogvallen. Ook in de Biesbosch is er een duidelijke toename van het potentiële 
intergetijdengebied bij de varianten $80 \mathrm{~cm}$ getij en Stormvloedkering. Opvallend bij de variant Klimaatscenario is de toename aan potentieel intergetijdengebied op de plaat van het land van Esche, ten westen van Strijensas. Dit gebied is in de variant Huidig beheer grotendeels terrestrisch. In het geval van de variant Klimaatscenario zal dit gebied in potentie regelmatig onder water komen te staan.

In Figuur 76 en in Figuur 77 (detailuitsnede oostelijk deel van het Haringvliet) van Bijlage 11 is aangegeven hoe het ecotoop Hoog intergetijdengebied gaat veranderen bij de verschillende varianten. Bij de variant $80 \mathrm{~cm}$ getij is er in het Haringvliet en in het Hollands Diep sprake van een netto toename van het areaal hoog intergetijdengebied (respectievelijk 45 en $37 \mathrm{ha}$ ). In de Biesbosch is er echter een netto afname van het areaal Hoog intergetijdengebied met 329 ha. Dit verlies in areaal Hoog intergetijdengebied in de Biesbosch komt voornamelijk ten goede van het areaal Zomer droog. In de variant Stormvloedkering is er ook in het middendeel van het Haringvliet te zien dat er areaal Hoog intergetijdengebied verloren gaat ten koste van het ecotoop Zomer droog. Een deel van dit verlies wordt gecompenseerd door nieuw areaal Hoog intergetijdengebied op locaties waar in de variant Huidig beheer nog een terrestrisch ecotoop bestond. De variant Klimaatscenario ten slotte laat zien dat het ecotoop Hoog intergetijdengebied vrijwel verdwijnt ten koste van het ecotoop Permanent intergetijdengebied.

\subsubsection{Arealen ecotopen}

De arealen van de verschillende ecotopen zijn berekend door het aantal rastercellen (20x20 m) per ecotoop over het hele studiegebied dan wel met onderscheid in deelgebieden (Haringvliet, Hollands Diep, Biesbosch, Spui en Dordtsche Kil, zie Figuur 1) bij elkaar op te tellen en te vermenigvuldigen met $400 \mathrm{~m}^{2}$ (oppervlakte van één rastercel).

Het totaal oppervlakte van het onderzoeksgebied is ruim 24.000 ha (Figuur 48 en Tabel 4). In de variant Huidig beheer is er in potentie ongeveer 6.500 ha (zoet) intergetijdengebied (ecotopen Permanent intergetijdengebied, Zomerdroog en Hoog intergetijdengebied). Het meeste van dit potentieel intergetijdengebied bevindt zich in het Haringvliet (2.240 ha) en de Biesbosch (3.635 ha). Bij de variant Kierbesluit komt er geen potentieel intergetijdengebied bij. Wel verandert er 583 ha (9\%) intergetijdengebied van zoet naar brak. In het sublitoraal komt er meer brakwatergebied bij (toename $3.541 \mathrm{ha}, 29 \%$ ). Bij de varianten $80 \mathrm{~cm}$ getij en Stormvloedkering neemt het areaal potentieel intergetijdengebied toe tot respectievelijk 7.774 en 8.354 ha (toename met respectievelijk 19 en $28 \%$ ). Bij de variant Klimaatscenario neemt het totale areaal aan potentieel intergetijdengebied weer af naar 7.946 ha (een afname met $9.6 \%$ ) in vergelijking tot de variant Stormvloedkering. Het potentieel intergetijdengebied bij de variant Klimaatscenario bestaat voornamelijk uit het ecotoop Permanent intergetijdengebied. De ecotopen Zomer droog en Hoog intergetijdengebied zijn maar beperkt (totaal $671 \mathrm{ha}$ ). 


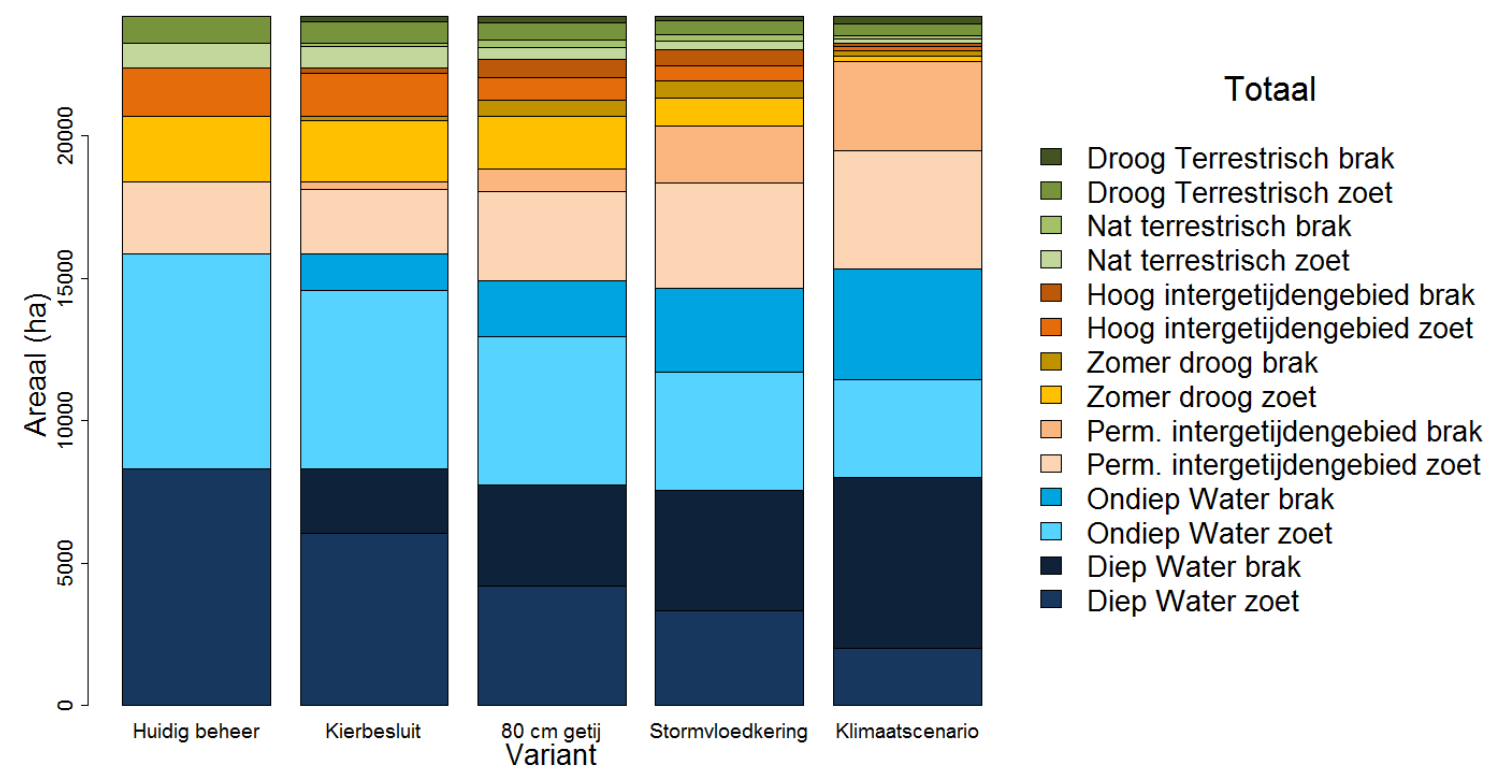

Figuur 48 Arealen ecotopen binnen het volledige modelgebied voor de varianten Huidig beheer, Kierbesluit, $80 \mathrm{~cm}$ getij, Stormvloedkering en Klimaatscenario.

\begin{tabular}{|c|c|c|c|c|c|}
\hline Ecotoop & $\begin{array}{l}\text { Huidig } \\
\text { beheer }\end{array}$ & Kierbesluit & $\begin{array}{c}80 \mathrm{~cm} \\
\text { getij }\end{array}$ & $\begin{array}{l}\text { Stormvloed- } \\
\text { kering }\end{array}$ & $\begin{array}{l}\text { Klimaat- } \\
\text { scenario }\end{array}$ \\
\hline+ & 8.303 & 6.062 & 4.209 & 3.325 & 2.010 \\
\hline Ondiep Water zoet & 7.546 & 6.264 & 5.224 & 4.159 & 3.421 \\
\hline Permanent intergetijdengebied zoet & 2.522 & 2.263 & 3.126 & 3.695 & 4.175 \\
\hline Zomer droog zoet & 2.314 & 2.162 & 1.812 & 1.011 & 202 \\
\hline Hoog intergetijdengebied zoet & 1.677 & 1.506 & 775 & 545 & 133 \\
\hline Nat terrestrisch zoet & 881 & 770 & 417 & 332 & 131 \\
\hline Droog Terrestrisch zoet & 944 & 752 & 610 & 486 & 419 \\
\hline Diep Water brak zoet & 15 & 2.257 & 3.526 & 4.232 & 5.999 \\
\hline Ondiep Water brak & 2 & 1.284 & 1.966 & 2.943 & 3.898 \\
\hline Permanent intergetijdengebied brak & 0 & 260 & 810 & 1.980 & 3.100 \\
\hline Zomer droog brak & 0 & 152 & 592 & 583 & 195 \\
\hline Hoog intergetijdengebied brak & 0 & 171 & 658 & 541 & 141 \\
\hline Nat terrestrisch brak & 0 & 112 & 258 & 210 & 118 \\
\hline Droog Terrestrisch brak & 1 & 193 & 223 & 165 & 264 \\
\hline Totaal & 24.206 & 24.206 & 24.206 & 24.206 & 24.206 \\
\hline Potentieel intergetijdengebied & 6.513 & 6.513 & 7.774 & 8.354 & 7.946 \\
\hline
\end{tabular}

In het Haringvliet (Figuur 69, Tabel 15) neemt het areaal potentieel intergetijdengebied bij de varianten $80 \mathrm{~cm}$ getij en Stormvloedkering toe met respectievelijk $24 \%$ en $37 \%$ ten opzichte van Huidig beheer en Kierbesluit tot respectievelijk 2.778 ha en 3065 ha. In de variant Klimaatscenario neemt het areaal intergetijdengebied weer af ten opzichte van de variant Stormvloedkering. Vooral de ecotopen Zomer droog en Hoog intergetijdengebied zijn bij de variant Klimaatscenario sterk gereduceerd tot respectievelijk 143 en 100 ha.

Het Hollands Diep bestaat voornamelijk uit de sublitorale ecotopen Diep water en Ondiep water (ca $79 \%$ van het totale areaal)(Figuur 70, Tabel 16 ). Ook hier leidt de toename van de getijslag tot een groter areaal aan potentiële intergetijdengebieden. Dit gaat voornamelijk ten koste van de terrestrische (nat en droog) ecotopen.

In de Biesbosch is er een duidelijke toename van het areaal potentieel intergetijdengebied met de varianten $80 \mathrm{~cm}$ getij en Stormvloedkering (Figuur 71, Tabel 17). Meer dan de helft van het gebied Biesbosch komt bij deze varianten onder invloed te staan van de getijdenwerking. Bij de variant Klimaatscenario is het areaal potentieel intergetijdengebied kleiner ( 4.130 ha) dan bij de variant 80 cm getij (4.217 ha). De toename van het areaal potentieel intergetijdengebied in de Biesbosch met 
het vergroting van de getijslag komt in potentie voornamelijk ten goede aan het ecotoop Permanent intergetijdengebied (zoet). Bij de variant Klimaatscenario behoort 47\% van het totale areaal tot dit type ecotoop. Dit gaat voornamelijk ten koste van de arealen van de ecotopen Zomer droog en Hoog intergetijdengebied die afnemen tot respectievelijk 145 ha en 75 ha.

In het Spui leidt de toename in getijslag duidelijk tot een toename in potentiële intergetijdengebieden (Figuur 72, Tabel 18). Het grootste areaal intergetijdengebied wordt hier verkregen bij de variant Klimaatscenario (27\% intergetijdengebied). De diversiteit aan ecotopen is het grootste bij de variant Klimaatscenario.

In de Dordtsche Kil zijn de effecten van de toename van de getijslag minder uitgesproken (Figuur 73, Tabel 19). De Dordtsche Kil heeft veel minder ondiepe gebieden. Op dit moment is er ongeveer 13 ha intergetijdengebied en dat wordt maximaal 20 ha bij de variant Stormvloedkering.

\subsection{Potentiële natuurwaarden ecotopen}

Er is een inschatting gemaakt van de potentiële natuurwaarden van de ontstane ecotopen voor de verschillende varianten, waarbij de focus ligt op de getijdennatuur, en niet zozeer op de terrestrische natuur. Deze laatste verandert wel in oppervlakte, maar waarschijnlijk slechts gering in natuurwaarde t.o.v. de huidige situatie door de aanwezigheid van een zoetwaterlens. Veranderingen in grondwaterstanden kunnen mogelijks wel tot een verandering in vegetatiesamenstelling leiden, maar is met de huidige kennis en beschikbare informatie moeilijk in te schatten.

Binnen de scope van deze studie is het niet mogelijk om een gedetailleerde beschrijving te geven van de te ontwikkelen natuurwaarden. Dit vraagt niet alleen nadere studie, maar ook een betere voorspelling van de zoutverdeling en overspoelingsfrequentie voor een meer exacte inschatting van de areaalontwikkelingen in elk scenario.

Estuariene- of getijdenatuur is natuur die zich ontwikkelt in het contact tussen zoet en zout water, tussen land en zee. Hét kenmerk van een estuarium is dynamiek en continue korte en lange termijn veranderingen. Denk maar aan eb en vloed, het geulenpatroon dat continu verandert en de wisselende zoutconcentraties. Het is een gebied met tal van natuurlijke overgangen: van droog naar nat, van zoet naar zout en van een stabiele naar een instabiele bodem. Door al deze overgangen zijn er een groot aantal verschillende habitats. Het meest kenmerkend voor estuariene gebieden zijn schorren, slikken en zandplaten, ondiepwater gebieden en diepwater (o.a. geulen).

De bestudeerde varianten leiden t.o.v. het Huidig beheer enerzijds tot een toename van het areaal brakwatergebieden (alle varianten), anderzijds tot een toename in het areaal intergetijdengebied (schorren, slikken en zandplaten) (80 cm Getij, Stormvloedkering en Klimaatscenario's). Aangezien de soortensamenstelling en -diversiteit in een estuarium sterk variëren langs de horizontale (longitudinale zoutgradiënt) en verticale gradiënt (overspoelingsduur of droogvalduur), zullen de verschillende varianten leiden tot een verschuiving in biodiversiteit en soortensamenstelling. Gezien de grote onzekerheden in de zoutzones, maar ook in de berekende areaal oppervlaktes, wordt hier een algemene evaluatie van de veranderingen in natuurwaarden gemaakt. Hierbij wordt ook geen rekening gehouden met mogelijke andere wijzigingen in het systeem als gevolg van de verhoogde uitwisseling met de Noordzee zoals primaire productie, zwevend stof, zuurstofhuishouding, daar deze gegevens ontbreken.

\subsubsection{Brakwater ecotopen}

Het ontstaan van brakwater ecotopen in het studiegebied leidt tot (gedeeltelijk) herstel van de situatie vóór de bouw van de Haringvlietsluizen. Voor de deltawerken vormde de Haringvliet - Hollands Diep Biesbosch één estuarium met een geleidelijke overgang van zoetwatergetijdengebied (Biesbosch) naar brakwatergetijdengebied (Hollands Diep en grootste deel van de Haringvliet), naar een zoutwatergetijdengebied (mondingsgebied Haringvliet). Deze geleidelijke estuariene overgangen (met verticaal getij) zijn zeldzaam geworden in Nederland (en Europa) en vooral met het scenario 
Stormvloedkering en Klimaatscenario worden deze omstandigheden terug grotendeels hersteld. Hiermee wordt een habitat dat op Europese schaal relatief zeldzaam geworden is hersteld.

Het brak worden van delen van het studiegebied zal een direct effect hebben op de planten en dieren die er leven. De verwachting is dat de varianten niet gaan leiden tot echte mariene (polyhaliene, saliniteit > 18 ppt) condities, maar dat er in hoofdzaak brakke (meso- en oligohaliene) condities zullen ontstaan. In de varianten Stormvloedkering en Klimaatscenario zullen in het westelijk deel van de Haringvliet waarschijnlijk de meest zoute condities ontstaan, met name tijdens de vloed. De exacte verdeling van het zout langs de horizontale gradiënt is echter moeilijk in te schatten met het huidige modelinstrumentarium (zie §4.5) en behoeft nader onderzoek. Wel staat vast dat in het gebied waar regelmatig zoutwater invloed merkbaar zal worden zal het merendeel van de zoetwaterflora en -fauna verdwijnen. De meeste zoetwater bodemfauna zal verdwijnen in de brakwaterzone, enkele soorten uitgezonderd die licht brakke omstandigheden kunnen overleven. Zo zullen schelpdieren zoals korfschelpen (Corbicula spp.) en Dreissenidae (driekhoeks- en quaggamosselen) verdwijnen in deze zone en plaats maken voor brakwatersoorten en soorten met een brede saliniteitsrange die schommelingen in zoutgehalte goed kunnen verdragen. Hierbij moet gedacht worden aan soorten zoals de zeeduizendpoot Hediste diversicolor en andere borstelwormen, slijkgarnalen Corophium spp. en andere kreeftachtigen, wadslakjes, Oligochaeta, etc. (Ysebaert et al., 2013b). Bij wat hogere zoutgehaltes zullen ook soorten zoals platte slijkgaper, nonnetje en allerlei borstelwormen voorkomen. Ook mobiele soorten zoals garnalen, steurgarnalen en aasgarnalen zullen in de brakwaterzone kunnen gedijen. De soortenrijkdom in zo'n brakwaterzone zal eerder laag zijn (zie ook Figuur 41), maar de soorten kunnen wel in hoge dichtheden voorkomen, zeker in de wat rustigere gebieden. Hoge rivierafvoeren kunnen zorgen voor het voor een langere tijd terug zoet maken van (delen van) de brakwaterzone. Dit kan leiden tot het (tijdelijk) weer afsterven van brakwater bodemdieren, waarna herstel optreedt. Zuurstofloosheid door stratificatie (al dan niet tijdelijk) in de diepere putten kan ook tot een verarming van de bodemfauna leiden.

Alle scenario's zullen leiden tot een verbetering voor vismigratie (zie ook Van Leeuwen et al., 2004 voor variant Kierbesluit). Tegelijkertijd zal het ontstane brakwatergebied ook functioneren als leefgebied voor typische brakwatervissoorten, maar ook echte estuariene residente soorten kunnen weer populaties opbouwen (Van Leeuwen et al., 2004). De brakwaterzone zal ook als kraam- en kinderkamer kunnen fungeren voor soorten zoals haring, schar, schol, tong en wijting (Van Der Molen, 2012; Griffioen et al., 2017).

In hoeverre de vogelstand beïnvloed wordt door het ontstaan van een brakwatergebied in de verschillende scenario's is moeilijk in te schatten. Het verdwijnen van driekhoeks- en quaggamosselen kan mogelijk een negatief effect hebben op duikeenden als kuif- en tafeleend. Het herstel van vismigratie en van visbestanden in de brakwaterzone zal positief zijn voor visetende vogels zoals sternen. In hoeverre er interessante broedgebieden ontstaan in de scenario's met meer getij is moeilijk te voorspellen. Mogelijks kunnen op de hogere delen van het intergetijdengebied in de brakwaterzone (ecotopen Zomer droog en Hoog Intergetijdengebied) mogelijkheden ontstaan voor broedvogels. Dit zal onder meer afhangen van de vegetatieontwikkeling in deze zones.

\subsubsection{Intergetijdengebieden}

De scenario's $80 \mathrm{~cm}$ Getij, Stormvloedkering en Klimaatscenario resulteren in een toename in intergetijdengebied, zowel in de brakke zone als de zoete zone. De verwachting is dat het areaal brakwater intergetijdengebied toeneemt met de varianten $80 \mathrm{~cm}$ Getij < Stormvloedkering < Klimaatscenario (Tabel 4). De toename in potentieel intergetijdengebied komt vooral door een toename van het ecotoop Permanent intergetijdengebied, terwijl de ecotopen Zomer droog en Hoog intergetijdengebied afnemen, met name in de scenario's Stormvloedkering en Klimaatscenario. Deze laatste twee ecotopen zijn ecotopen die typisch verbonden zijn met het studiegebied, ontstaan door verschillen in rivierafvoer tussen zomer en winter, en daardoor in waterstanden. De gemodelleerde arealen van de potentiële intergetijdengebieden moeten wel met de nodige voorzichtigheid behandeld worden. Lokale topografie, bijv., het voorkomen van oeverwallen of dijkjes kan het overstromen van een bepaald gebied beperken of verhinderen, waardoor andere natuurwaarden ontstaan. Daarom is het op basis van deze studie niet mogelijk om exacte uitspraken te doen over welke natuurwaarden en 
soorten (en in welke mate) zullen ontwikkelen in het studiegebied (zie discussie over potentiële intergetijdengebieden in §7.2).

De toename van intergetijdengebied in het studiegebied zorgt voor een herstel van dit ecotoop dat door de deltawerken fors is afgenomen. Intergetijdengebieden (schorren, slikken en zandplaten) zijn waardevolle, maar ook zeldzaam geworden ecotopen in Nederland en Europa die op veel plaatsen onder druk staan. Intergetijdengebieden herbergen een specifieke flora en fauna en zijn doorgaans zeer productief, wat ten goede komt aan heel wat hogere trofische niveaus, zoals vissen en vogels. Zowel brakwater intergetijdengebieden als zoetwater intergetijdengebieden zijn zeldzame habitats in Nederland en Europa, en worden in de scenario's $80 \mathrm{~cm}$ Getij, Stormvloedkering en Klimaatscenario in toenemende mate hersteld.

\section{Hoog intergetijdengebied en Zomer droog}

De ecotopen Zomer droog en Hoog intergetijdengebied zijn ecotopen waar vegetatieontwikkeling zal optreden. De hogere delen van het Hoog intergetijdengebied staan nagenoeg permanent droog, terwijl de lagere delen de hele zomer droog staan (Tabel 5). Hierdoor zal op de meeste delen permanente vegetatie ontwikkelen. In het ecotoop Zomer droog staan de hogere delen tijdens de zomerperiode meestal droog (dit neemt wel fors af in het Klimaatscenario), terwijl de lagere delen vaker overspoeld zullen worden (Tabel 5). De verwachting is dat in het ecotoop Zomer droog zich meer pioniervegetaties zullen ontwikkelen, omwille van het meer frequent overstromen van deze zone in de winterperiode(Tabel 5).

Welke vegetatie zich gaat ontwikkelen in het gebied hangt af van een heleboel factoren. De belangrijkste ecologische factoren die de aanwezigheid van flora en de successie op schorren bepalen zijn zoutgehalte (Figuur 49), overstromingsdynamiek (frequentie, -duur en -hoogte), sediment input, bodemtextuur en de daaraan gekoppelde zuurstofhuishouding, verzanding, stikstofgehalte in de bodem en huidig- en historisch beheer. De vegetatieontwikkeling binnen elke variant is moeilijk te voorspellen, mede door de complexe topografie binnen het gebied.

Op de brakwaterschorren kunnen op de lagere delen pioniervegetaties voorkomen zoals nopjeswier (vaucheria), die de opslibbing in de hand werken. Daarna volgen soorten als zeebies of heen, waartussen zich zeeaster vestigt. Op de hogere delen komt ook spiesmelde op de voorgrond en treffen we echt lepelblad aan, een exclusieve brakwatersoort. Hoger op het schor ontwikkelen zich soortenarme vegetaties gedomineerd door strandkweek en finaal riet.

Op de zoetwaterschorren kunnen pioniervegetaties voorkomen met ganzenvoet- en tandzaadsoorten. Daarnaast kunnen verruigde rietlanden met grote brandnetel en vitale rietlanden met lokaal zeer specifieke soorten zoals de spindotterbloem en biezenvegetaties (bastaardbies, ruwe bies, mattenbies, heen, driekantige bies) zich ontwikkelen (zie Ysebaert et al., 2013b voor bijkomende informatie over voorkomen van typische soorten; https://www.natura2000.vlaanderen.be/habitattype/estuaria). De herintroductie van getij kan leiden tot herstel van de kenmerkende biezenvegetaties.

Successie op schorren leidt vroeg of laat tot monotone, vaak monospecifieke vegetaties van zeekweek (zoutwaterschorren), riet (brakwaterschorren) of wilg (zoetwaterschorren) (Figuur 49). Beheer is daarom een belangrijke factor in het behoud van structurele en biologische diversiteit. Vroeger was begrazing een belangrijke gebruiksvorm van zout- en brakwaterschorren; deze leidde tot kortgrazige kweldergrasvegetaties.

De ontwikkeling van de vegetatie zal zich doorvertalen naar de broedvogels die gebruik maken van deze habitats. Zoetwater- en brakwaterschorren zijn belangrijk voor broedende riet- en moerasvogels zoals bruine kiekendief, blauwborst, rietzanger, bosrietzanger, rietgors, cetti's zanger en baardmannetje. Rietvogels zullen profiteren van een toename in het voorkomen van uitgestrekte rietvelden. In de varianten $80 \mathrm{~cm}$ Getij en Stormvloedkering zal de ontwikkeling van brakwatervegetaties het grootst zijn. Onder het huidige beheer en het Kierbesluit komt het grootste areaal zoet Zomer droog en Hoog intergetijdengebied voor. In de variant Klimaatscenario nemen de arealen van deze ecotopen fors af, ten voordele van vooral Permanent intergetijdengebied, waardoor het areaal voor broedvogels bij deze variant zal afnemen. 
Naar alle waarschijnlijkheid zal er weinig tot geen geschikt broedgebied voor kustbroedvogels (i.e. kale grond broeders) ontstaan, door de vegetatieontwikkeling in deze ecotopen. Hiervoor zal gericht beheer noodzakelijk zijn. Ook is nader onderzoek nodig naar de invloed van het voorkomen van extreme waterstanden in de zomerperiode op broedvogels.

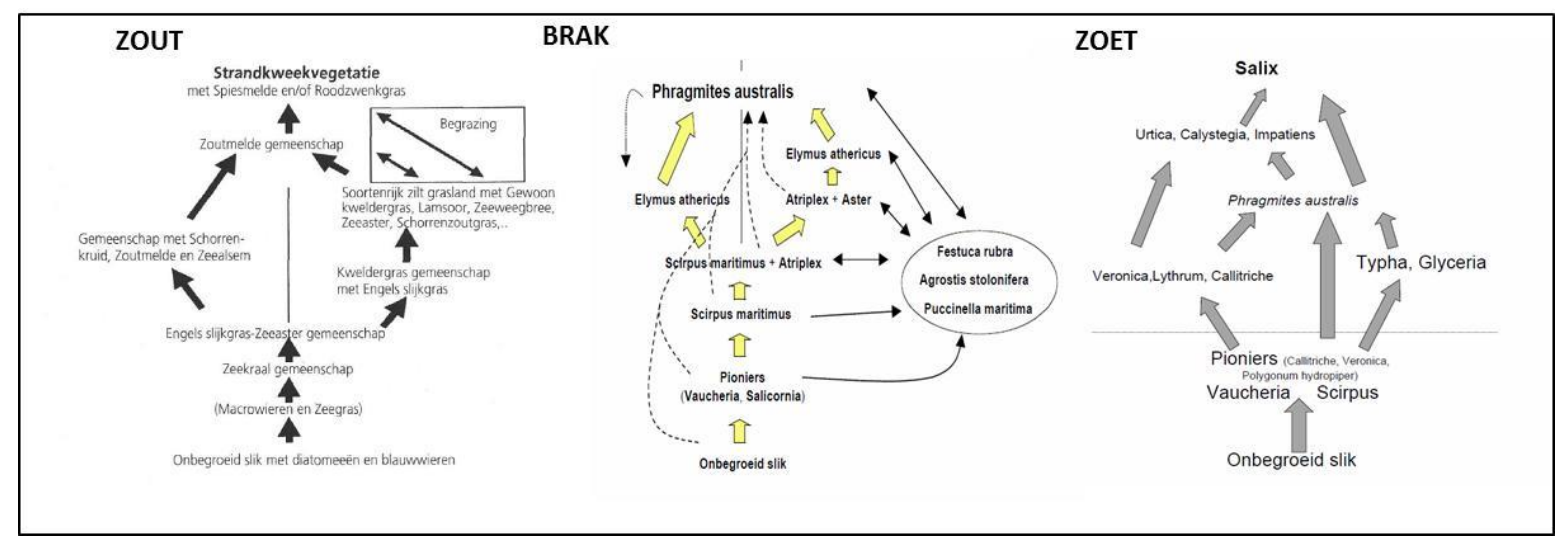

Figuur 49 Successie patronen van zoute, brakke en zoetwater schorren (Vandenbussche, T'Jollyn e.a. 2002, uit Ysebaert et al., 2013b).

\section{Permanent intergetijdengebied}

Het areaal Permanent intergetijdengebied zal grotendeels bestaan uit niet begroeide slikken en platen, de zone in het estuarium die regelmatig droog komt te liggen: bij vloed overstromen ze met water en bij eb vallen ze droog. Op de allerhoogste delen van het Permanent intergetijdengebied kan mogelijk ook pioniervegetatie ontwikkelen. Slikken en platen zijn doorgaans hoogproductieve systemen en ze kennen een zeer rijk bodemdierleven (het zogenaamde zoöbenthos). Slikken en platen hebben naast de functie als leefgebied van bodemdieren nog andere functies, zoals rui-, rust- en foerageergebied voor vogels, foerageergebied voor (jonge) vis en hyperbenthos (o.a. kinderkamerfunctie) en rust- en zoogplaats voor zeezoogdieren (Ysebaert et al., 2013b).

Het areaal Permanent intergetijdengebied neemt toe met de varianten: Huidig beheer $=$ Kierbesluit < $80 \mathrm{~cm}$ Getij < Stormvloedkering < Klimaatscenario. Vooral in de scenario's Stormvloedkering en Klimaatscenario neemt het areaal fiks toe, met name het Permanent intergetijdengebied brak (situeert zich vooral in de Haringvliet), maar ook het Permanent intergetijdengebied zoet (vooral in de Biesbosch). Toename in het areaal Permanent intergetijdengebied betekent dat het studiegebied meer geschikt wordt voor vogels die bij laagwater in deze gebieden foerageren op bodemdieren of zaden van planten. Het gaat hier met name om steltlopers en watervogels zoals eenden en ganzen. In kreekjes en poeltjes kunnen onder meer reigers en lepelaars geschikt voedsel vinden.

In de brakke zone zullen de slikken en platen een typische brakwaterfauna herbergen (zie §6.4.1). Deze brakwater bodemfauna zal niet zeer soortenrijk zijn, maar soorten kunnen wel in hoge dichtheden voorkomen, bijv. zeeduizendpoot Hediste diversicolor, slijkgarnaal Corophium spp., wadslakjes, Oligochaeta, etc. (zie §6.4.1). Tijdens laagwater vormen deze slikken en platen een geschikt foerageergebied voor allerlei soorten steltlopers en watervogels (o.a. bonte strandloper, tureluur, zwarte ruiter, groenpootruiter, zilverplevier, wintertaling, krakeend, smient, bergeend). Deze zullen dan ook profiteren van de toename in areaal permanent intergetijdengebied Tijdens hoogwater kunnen vissen de slikken en platen optrekken om te foerageren op de aanwezige bodemdieren. Omwille van het brakke karakter zullen bepaalde belangrijke prooisoorten voor steltlopers (bijv. scholekster, wulp), zoals wadpieren, kokkels en mosselen zich niet vestigen op deze intergetijdengebieden. Deze soorten komen meer in zoute omstandigheden voor. Vooral op de slikkerige delen zullen soorten zoals ruiters en strandlopers geschikt voedsel kunnen vinden. 


\section{$7 \quad$ Conclusies en discussie}

\subsection{Conclusies onderzoeksvragen}

Aan de hand van de in $§ 1.3$ geformuleerde onderzoeksvragen kunnen op basis van voorliggend onderzoek de volgende conclusies worden getrokken:

\section{Waar liggen de potenties voor intergetijdengebieden bij verschillende varianten van sluisbeheer en welke arealen zijn hierbij in potentie mogelijk?}

Het toelaten van getij via de Haringvlietsluizen leidt tot een grotere getijslag in de Haringvliet, Hollands Diep, Biesbosch, Spui en Dordtsche Kil. De grootste getijslag (ca 1,4 meter, in vergelijking tot ca $40 \mathrm{~cm}$ in de variant Huidig beheer en bij de variant Kierbesluit) wordt verkregen in de varianten waarbij de Haringvlietsluizen fungeren als stormvloedkering, waarbij de sluizen alleen worden gesloten bij extreme waterstanden op de Noordzee. De variant Klimaatscenario leidt naast een toename in de getijslag ook tot een verhoging in de middenstand naar ca $65 \mathrm{~cm}$ NAP. Dit is $\sim 20 \mathrm{~cm}$ hoger dan de middenstand in de variant Huidig beheer en $\sim 35 \mathrm{~cm}$ hoger dan de middenstand in de variant Stormvloedkering.

In het Haringvliet neemt het potentieel intergetijdengebied voornamelijk toe rond de Slijkplaat en de Ventejagersplaten (Figuur 1). Als gevolg van de zeespiegelstijging zal een deel van dit potentieel intergetijdengebied weer verdwijnen omdat de middenstand hoger komt te liggen. Dit alles onder de aanname dat de bodem niet zal veranderen. Er kan worden aangenomen dat de bodem in de loop van de jaren wel in meer of mindere mate zal veranderen als gevolg van sedimentatie en erosieprocessen. Een deel van de terrestrische ecotopen rond het eiland Tiengemeten zullen onder invloed van het getij komen te staan.

In het Hollands Diep is de toename aan areaal potentieel intergetijdengebied beperkt. Bij de variant Klimaatscenario ontstaat er wel een aanzienlijk areaal aan potentieel intergetijdengebied bij plaat van het land van Esche, ten westen van Strijensas.

In de Biesbosch komt er ook een aanzienlijk areaal potentieel intergetijdengebied bij (respectievelijk 583, 781 en 495 voor de varianten $80 \mathrm{~cm}$ getij, Stormvloedkering en Klimaatscenario). Bij de variant Klimaatscenario zal dit echter voornamelijk Permanent intergetijdengebied gaan worden en minder Zomer droog en Hoog intergetijdengebied. De Noordwaard is in deze berekeningen niet meegenomen.

In het Spui en vooral de Dordtsche Kil is de toename in potentieel intergetijdengebied beperkt vanwege de relatief steil aflopende oevers.

\section{Welke natuurwaarden kunnen er ontstaan binnen de intergetijdengebieden, rekening houdend met zoutfluctuaties, ontwikkeling bodemleven, voedselbeschikbaarheid voor vogels en broedmogelijkheden voor vogels?}

Alle onderzochte varianten zorgen voor een toename in de diversiteit aan ecotopen en habitats. Dit is te wijten aan een grotere variatie langsheen de horizontale (longitudinale zoutgradiënt) en verticale gradiënt (overspoelingsduur of droogvalduur). Dit leidt tot een verschuiving in biodiversiteit en soortensamenstelling in het studiegebied. Algemeen kan gesteld worden dat de biodiversiteit zal toenemen in het studiegebied, en dat het gebied weer een meer estuarien karakter krijgt, door introductie van zout water uit de Noordzee (alle varianten) en een vergroting van de getijslag (scenario's $80 \mathrm{~cm}$ Getij, Stormvloedkering en Klimaatscenario). Het herstel van estuariene dynamiek is het grootst in de variant Stormvloedkering. De variant Klimaatscenario laat zien hoe zeespiegelstijging wel degelijk effect zal hebben op het studiegebied in het algemeen, en in het voorkomen van intergetijdengebieden in het bijzonder. Het herstel van estuariene dynamiek zal leiden tot herstel van typische estuariene soorten en gemeenschappen, tot op zekere hoogte vergelijkbaar met de situatie van vóór de deltawerken. 
Door het specifieke karakter van het studiegebied, met lagere rivierafvoeren in de zomer, en daarmee gepaard gaande lagere waterstanden, komen in het studiegebied drie types intergetijdengebied ecotopen voor: Permanent intergetijdengebied, Zomer droog en Hoog intergetijdengebied. In de twee laatstgenoemde zal zich vegetatie kunnen ontwikkelen, met vooral permanente vegetatie op het Hoog Intergetijdengebied, en meer pioniervegetatie in het Zomer droog ecotoop. Omwille van het vaak lang droogvallen zal zich hier geen permanente benthische macrofauna gemeenschap kunnen ontwikkelen. Het Permanent intergetijdengebied zal vooral uit niet-begroeide slikken en platen bestaan en belangrijk zijn als foerageergebied voor vogels en vissen door het voorkomen van bodemdieren.

Het grootste areaal potentieel intergetijdengebied wordt gerealiseerd in de variant Stormvloedkering, bij deze variant komt tevens naast Permanent intergetijdengebied ook de ecotopen Zomer droog en Hoog Intergetijdengebied in relatief grote oppervlaktes voor. Deze laatste twee verdwijnen grotendeels bij de variant Klimaatscenario ten voordele van Permanent intergetijdengebied, terwijl in de varianten Kierbesluit en $80 \mathrm{~cm}$ getij (net als in het Huidig beheer) deze twee ecotopen een groter areaal vormen t.o.v. scenario Stormvloedkering, waardoor in deze scenario's meer met vegetatie begroeid zal voorkomen. Dit zal een invloed hebben op de broedvogels die in deze habitats kunnen broeden. De gemodelleerde arealen van de potentiële intergetijdengebieden moeten wel met de nodige voorzichtigheid behandeld worden. Lokale topografie, bijv., het voorkomen van oeverwallen of dijkjes kan het overstromen van een bepaald gebied beperken of verhinderen, waardoor andere natuurwaarden ontstaan (zie discussie over potentiële intergetijdengebieden in §7.2).

De verschillende varianten resulteren in een toename van de brakwaterzone in het studiegebied, die is hoogstwaarschijnlijk het grootst in het Klimaatscenario en het kleinst in de variant Kierbesluit. Brakwaterzones zijn zeldzaam in Nederland en Europa en worden dus deels hersteld. Voor de deltawerken was het studiegebied immers één groot estuarium met een uitgebreide brakwaterzone. Het brak worden van delen van het studiegebied zal een direct effect hebben op de planten en dieren die er leven. De verwachting is dat de scenario's niet gaan leiden tot echte mariene (polyhaliene, saliniteit > 18 ppt) condities, maar in hoofdzaak brakke condities. Op de brakke Permanente intergetijdengebieden zal zich een bodemfauna ontwikkelen die kan omgaan met de brakke omstandigheden. Het betreft een niet zeer soortenrijke gemeenschap van typische soorten zoals zeeduizendpoten, slijkgarnaaltjes, wadslakjes, borstelloze wormen, etc. Deze kunnen in grote aantallen voorkomen en als voedsel dienen voor vogels en vissen. De biomassa zal wel lager zijn dan in echt zoute omstandigheden, door het ontbreken van grotere soorten zoals wadpieren, kokkels, mosselen, etc. De brakwaterzone zal fungeren als leefgebied voor brakwatervissoorten en echte estuariene vissoorten en de slikken en platen zullen fungeren als foerageergebied. Bij laagwater zullen bepaalde soorten steltlopers en eendachtigen foerageren op de brakwater slikken en platen.

In de zoete zone zal in de scenario's $80 \mathrm{~cm}$ Getij, Stormvloedkering en Klimaatscenario het zoetwater (inter)getijdengebied toenemen. Het herstel van dit zeldzame ecosysteem met typische habitats en soorten (bijv. biezenvegetaties, spindotter) zal de natuurwaarde van deze zone vergroten.

\section{Is het mogelijk om met een grotere sluisopening, en de daaraan gekoppelde verhoging van de getijdynamiek de natuurlijke plaatopbouw terug te krijgen? Zo nee, welke aanvullende maatregelen zijn er mogelijk om plaatopbouw te stimuleren?}

Zelfs met de variant Stormvloedkering, wanneer de sluizen alleen bij hoge waterstand bij Hoek van Holland zullen sluiten, zal er naar verwachting onvoldoende dynamiek in het systeem terugkomen om de natuurlijke plaatopbouw terug te krijgen. Mogelijke flankerende maatregelen zijn lokale zandsuppleties, waarbij op een plaat zand wordt gesuppleerd om tijdelijk zodoende meer areaal intergetijdengebied met juiste droogvalduur te creëren.

\section{Neemt de zandhonger in het Haringvliet toe als gevolg van zeespiegelstijging? Zo ja, welke maatregelen zijn er mogelijk om de negatieve effecten hiervan te mitigeren?}

In de huidige situatie is er sprake van zandhonger, dat wil zeggen dat het doorstroomoppervlak van de geulen te groot is ten opzichte van het getijvolume. Hierdoor wil het systeem aanzanden. Bij huidig 
beheer en aanbod van sediment, zal het naar verwachting honderden jaren duren voor een nieuw evenwicht is bereikt. Hoewel bij de variant stormvloedkering door de toename van de getijdynamiek de zandhonger zal verminderen, blijft ook voor deze situatie de zandhonger aanwezig en zal het, afhankelijk van de sedimentatiesnelheid, nog naar schatting ruim 100 jaar duren voor een nieuw evenwicht wordt bereikt.

Gezien de huidige sedimentatiesnelheid in het Haringvliet en Hollands Diep $\left(0,2-2 \mathrm{~cm} \mathrm{jaar}^{-1}\right)$, zal de bodem naar verwachting wel kunnen meegroeien met de zeespiegelstijging, welke momenteel $0,2 \mathrm{~cm}$ jaar $^{-1}$ bedraagt. Wanneer echter de zeespiegelstijging gaat versnellen of de sedimentatiesnelheid gaat afnemen bestaat de kans op toename van zandhonger. Dit alleen als de zeespiegelstijging sneller gaat als de sedimentatiesnelheid. Flankerende maatregelen zijn de bij punt 3 genoemde zandsuppleties, welke gericht zijn op het mitigeren van de afname van het areaal intergetijdengebied.

\section{Wat zijn de mogelijke morfologische gevolgen van een ander beheer van de Haringvliets/uizen voor de buitendelta van het Haringvliet?}

Vele ingrepen hebben de afgelopen decennia bijgedragen aan de morfologische veranderingen in de buitendelta van het Haringvliet, waaronder de afsluiting van de Brielse Maasmonding (1950, 1966), de uitbreiding van het Rotterdamse Havengebied met onder andere de Maasvlakte (1964-1976), Slufterdam (1986-1988) en de Maasvlakte 2 (2008-2013), en de constructie van de Haringvlietsluizen (1958-1971) met de uiteindelijke afsluiting van het Haringvliet in 1971. Door deze ingrepen zijn de getijvolumes afgenomen, is de relatieve invloed van de golven toegenomen en is de buitendelta meer afgeschermd geraakt voor golfinvloed vanuit het Noordwesten. Hierdoor is de buitendelta landwaarts verplaatst, zijn de noordelijke geulen dichtgeslibd, zijn de platen van locatie en oriëntatie veranderd, is het areaal intergetijdengebied toegenomen en is de Kwade Hoek aangegroeid door sediment uit de buitendelta van het Grevelingen.

Zelfs wanneer de sluizen weer volledig geopend zullen worden (variant stormvloedkering) zal het gebied niet terug veranderen naar de situatie voor de afsluiting, omdat enerzijds de vele ingrepen het gebied onomkeerbaar veranderd hebben en anderzijds de dam een barrière zal blijven vormen voor water- en sedimentuitwisseling. Omdat door het openen van de sluizen het getijvolume zal toenemen, wordt verwacht dat de bestaande geulen minder sterk zullen aanzanden of weer zullen verruimen. Daarnaast zal het areaal intergetijdengebied afnemen door enerzijds erosie van platen en slikken en anderzijds door afname van de getijslag. Omdat het Slijkgat nu de enige getijgeul is, zullen de morfologische veranderingen naar verwachting het grootste zijn in het zuidelijke deel van de buitendelta. Voor een kwantificering van de effecten is een uitgebreide analyse nodig.

\subsection{Discussie}

\section{Varianten}

In deze studie zijn vijf varianten uitgewerkt (Huidig beheer, Kierbesluit, $80 \mathrm{~cm}$ getij, Stormvloedkering en Klimaatscenario). Het doel van deze varianten was het speelveld van mogelijkheden in kaart te brengen. Bij de varianten Huidig beheer en Kierbesluit wordt er geen extra getij toegelaten en bij de variant stormvloedkering (en Klimaatscenario) wordt er maximaal getij binnengelaten via de Haringvlietsluizen. Bij de keuze van de varianten lag de focus op de natuurwaarden van de intergetijdengebieden. De haalbaarheid van de verschillende varianten in relatie tot kosten, fysische beperkingen en/of conflicten met andere gebruiksfuncties (e.g. zoetwatervoorziening, waterveiligheid, scheepvaart) is in deze studie niet onderzocht.

De resultaten laten zien wat er in potentie mogelijk is met betrekking tot de ontwikkeling van getijdenatuur. Bij een eventuele keuze van een ander beheer van de Haringvlietsluizen om meer getij toe te laten in het gebied zal uiteraard ook rekening dienen te worden gehouden met fysische, socioeconomische en politieke haalbaarheid. Het in onderhavige studie ontwikkelde model kan dan worden gebruikt om een dergelijke alternatieve keuze door te rekenen. 


\section{Potentiële intergetijdengebieden}

In deze studie is het areaal potentieel intergetijdengebied berekend door de bodemligging te relateren aan de waterstandfluctuaties. Er is daarbij niet onderzocht of het water de potentiële intergetijdengebieden ook daadwerkelijk kan bereiken. Lokale topografie, bijvoorbeeld het voorkomen van oeverwallen, dijkjes of andere hooggelegen structuren kunnen een obstructie vormen voor het transport van het getijdenwater naar achterliggende, lagergelegen delen. Een voorbeeld hiervan is de Beningerwaard. In de ecotopenkaart wordt een groot deel van dit gebied voor de variant Huidig beheer en Kierbesluit aangemerkt als Permanent intergetijdengebied (Figuur 50). Dit gebied ( $0.5 \mathrm{~m}$ NAP) is echter omsloten door hoger gelegen ecotopen ( $\sim 1 \mathrm{~m} \mathrm{NAP}$ ). Dit is goed te zien in Figuur 51. Het getijdewater kan dit gebied alleen bereiken als er verbindingen zijn (of worden) gemaakt. Als dit niet het geval is zal dit gebied een terrestrisch karakter blijven behouden. Naast de Beningerwaard geldt dit voor meerdere locaties binnen het onderzoeksgebied (e.g. Tiengemeten). Om deze reden spreken we in deze studie dan ook over potentiële intergetijdengebieden. Het areaal potentieel intergetijdengebied zal groter zijn dan het werkelijke intergetijdengebied. Mogelijk zijn er maatregelen nodig, zoals het weggraven van delen van oeverwallen of dijkjes om het getijdewater daadwerkelijk te kunnen toelaten. In een vervolgstudie zou het interessant zijn om voor de varianten Huidig beheer/Kierbesluit de ecotopen voor een aantal kleine gebieden in detail te vergelijken met de werkelijke situatie.

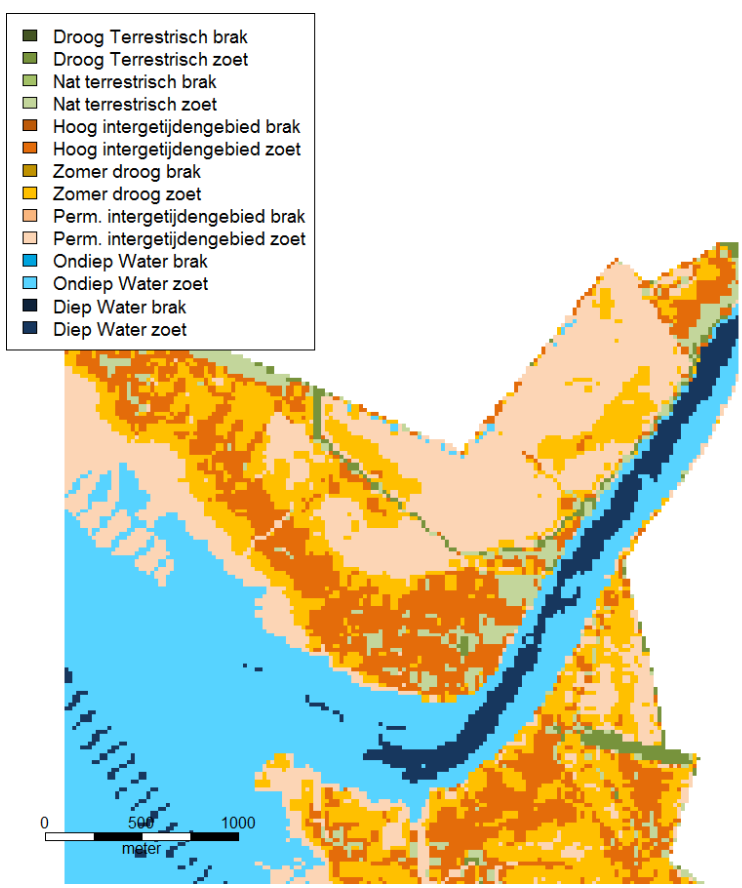

Figuur 50 Uitsnede ecotopenkaart van het gebied Beningerwaard voor de variant Huidig beheer. 


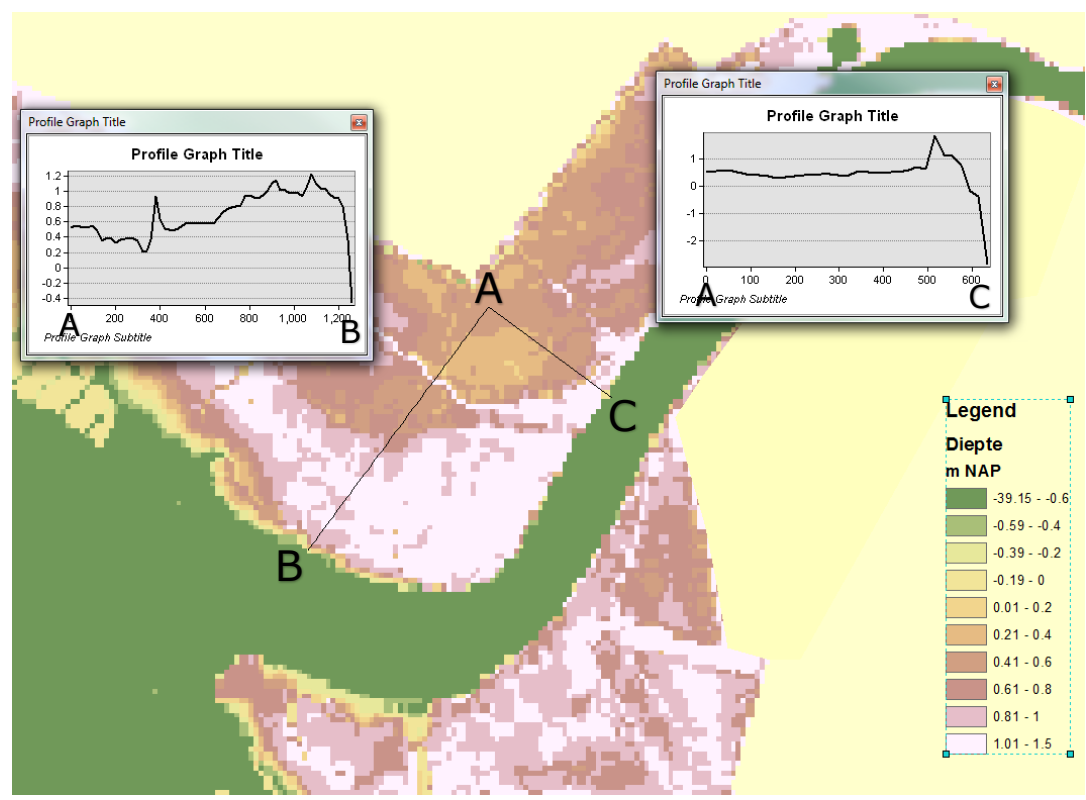

Figuur 51 Detailweergave van de diepte (m NAP) rond Beningerwaard. De grafieken laten het diepteprofiel zien van de transecten $A-B$ en $A-C$.

In de MER studie (Rijkswaterstaat, 1998d) is een overzicht gegeven van het verlies aan intergetijdengebied als gevolg van de afsluiting van het Haringvliet. Voor de afsluiting was het areaal intergetijdengebied in het Haringvliet, Hollands Diep en Biesbosch samen 6,550 ha. Na de afsluiting is dit areaal teruggebracht tot 320 ha. In voorliggende studie komen we voor de variant Huidig beheer tot een potentieel areaal permanent intergetijdengebied van 2,522 ha. Dit is aanzienlijk groter dan de 320 ha uit de MER-studie. Dit verschil kan mogelijk het gevolg zijn van de obstructie van het getijdendynamiek door oeverwallen en dijkjes in het onderzoeksgebied (zie vorige alinea). Het areaal permanent intergetijdengebied voor de variant stormvloedkering (5,675 ha) is $85 \%$ van het areaal intergetijdengebied dat aanwezig was voor de afsluiting (Rijkswaterstaat, 1998d). Voor de variant stormvloedkering wordt het areaal intergetijdengebied dus minder overschat.

Op basis van deze analyse is de verwachting dat het potentieel areaal intergetijdengebied voor de varianten Huidig beheer en Kierbesluit aanzienlijk groter is dan het werkelijke gerealiseerde areaal intergetijdengebied. Dit verschil is minder voor de varianten Stormvloedkering en Klimaatscenario omdat het getijdenwater bij een grotere getijslag over eventuele oeverwallen en andere obstructies heen kan stromen. Er zullen dan ook minder ingrepen nodig zijn de potentiele intergetijdengebieden daadwerkelijk te realiseren.

\section{Intergetijdengebied in getijdenrivieren}

Het intergetijdengebied in een rivierengebied, zoals Haringvliet, Hollands Diep en de Biesbosch, is anders dan wat we kennen van mariene getijdensystemen zoals de Ooster- en Westerschelde. In getijdenrivieren worden de waterstandsfluctuaties niet alleen beïnvloed door het dagelijks getij op zee, maar ook door de variatie in rivierafvoer. Deze laatste zorgt ervoor dat de middenstand varieert over de seizoenen. Bij een lage middenstand kan het voorkomen dat de hoge delen van het ecotoop Permanent intergetijdengebied gedurende langere tijd (dagen tot weken) droogvallen en bij een hoge middenstand kunnen de laaggelegen delen van dit ecotoop juist gedurende langere tijd onder water blijven staan. Dit effect zou kunnen worden meegenomen in de ecotopenindeling door het ecotoop Permanent intergetijdengebied onder te verdelen in sub-ecotopen van gebieden die over een $x$-aantal dagen droogvallen en gebieden die een y-aantal dagen onder water blijven staan. In de huidige studie is dit onderscheid niet gemaakt maar zou in een eventuele vervolgstudie kunnen worden meegenomen.

\section{Globale ontwikkelingen}

Hoewel de voorliggende studie een kleiner gebied (24.206 ha) beslaat dan de studie Samenhang in de Delta (120.093 ha) is ook deze studie vooral gericht op de globale veranderingen als gevolg van de 
voorspelde waterstanden bij de verschillende varianten. Doel van deze studie is om op een globale schaal ( 5 tot $10 \mathrm{~km}$ ) te verkennen hoeveel intergetijdengebied er kan worden verkregen, waar het ligt en wat de natuurpotentie is van deze gebieden.

Hoewel de ecotopenkaarten een grote mate van detail suggereren vanwege de onderliggende dieptekaart met een celgrootte van 20×20 meter, zijn de waterstanden gebaseerd op een 7-tal modellocaties. De getijstatistieken van deze locaties zijn geïnterpoleerd over het volledige onderzoeksgebied. Ook de grens tussen brakwater en zoetwater is een inschatting gebaseerd op kennis en ervaring en heeft een grote mate van onzekerheid (zie §4.5). In werkelijkheid zorgt de variatie in rivierafvoer ook voor het continue verschuiven van deze grens. Het model is daarmee niet geschikt om lokale details te voorspellen op de schaal (20×20 meter resolutie) van de ecotopenkaart. Bij de interpretatie van de resultaten op die schaal moet hiermee rekening worden gehouden.

\section{Oevererosie}

Wanneer in het Haringvliet en Hollands Diep de getijvariatie gaat toenemen ten gevolge van een grotere sluisopening ( $80 \mathrm{~cm}$ getij variant of stormvloedkering variant), zal de erosieve werking van de golven over een groter bereik worden verdeeld en zal daardoor de oevererosie afnemen en het talud van de oevers minder steil worden. De meeste oevers in het Haringvliet en Hollands Diep zijn echter kunstmatig beschermd met vooroeverbescherming of oeverbekleding. De vooroeverbescherming is aangelegd op een hoogte van 0,8 m NAP en gedeeltelijk verzakt. Door de grotere getijslag bij de onderzochte varianten zal de stroming in de doorgangen van de oeverbescherming toenemen. Uit een verkennende berekening blijkt dat deze vermoedelijk niet hoog genoeg zal zijn om tot erosie in de doorgangen te leiden. Omdat ook in de huidige situatie een deel van de vooroeverbescherming verzakt is, bestaat het vermoeden dat mogelijk erosie zal optreden door golfwerking of langsstroming. Omdat de langsstroming voor de onderzochte varianten zal toenemen, blijft de stabiliteit van de vooroeverbescherming een aandachtspunt.

Op locaties met vooroeverbescherming kan met name fijn sediment worden ingevangen. Voor de variant Stormvloedkering wordt verwacht dat meer slib ingevangen kan worden, omdat het aanbod van slib en het uitwisselingsdebiet met het gebied achter de vooroeverbescherming zullen toenemen. Een schatting van de sedimentatiesnelheid en de locaties waar dit kan optreden vergt een uitgebreidere analyse

\section{Bodembescherming Haringvlietsluizen}

Bij een grotere opening zullen de stroomsnelheden rond de sluizen toenemen. Hierdoor kunnen erosiekuilen ontstaan. Indien deze zich nabij de dam ontwikkelen en de taluds de steil worden kunnen ze een risico vormen voor de stabiliteit van de constructie. Hier is met de aanleg van de sluizen rekening gehouden en bodembescherming aangelegd. Met het oog op de ervaringen in de Oosterschelde, waar ondanks de bescherming toch diepe erosiekuilen zijn ontstaan nabij de kering, is het van belang de situatie nabij de Haringvlietsluizen goed in kaart te brengen alvorens met een alternatief sluisbeheer te starten.

\section{Morfologische ontwikkelingen Rijn-Maasmonding}

Door de afsluiting van het Haringvliet zijn de stroomsnelheden in een aantal riviertakken van de RijnMaasmonding toegenomen, waardoor deze takken (Oude Maas, Spui, Dordtsche Kil en Noord) nu sterk eroderen en de ontgrondingskuilen groeien. Indien deze kuilen te dicht in de buurt van keringen of andere infrastructuur komen, kunnen ze een risico vormen voor de stabiliteit. Wanneer de sluizen verder opengaan, zullen de stroomsnelheden in deze takken afnemen. Hoewel ook bij de stormvloedkering variant de stroomsnelheden niet terug zullen worden gebracht naar het niveau voor sluiting, zullen de stroomsnelheden wel flink afnemen, waardoor ook de huidige erostrends af zullen nemen. Voor een kwantificering is aanvullend onderzoek nodig.

\section{Dieptekaart}

De dieptekaart van het onderzoeksgebied die in deze studie is gebruikt is gebaseerd op de dieptekaart (20x20 meter grid) uit de studie "Samenhang in de Delta" (Ysebaert et al., 2013a; Ysebaert et al., 2013b; Ysebaert et al., 2016). In die studie was de dieptekaart voor de gebieden Westerschelde, Oosterschelde, Veerse Meer, Grevelingenmeer en Volkerak-Zoommeer geconstrueerd uit de 
dieptelodingen en het algemeen hoogtebestand Nederland. Voor de stagnante wateren (e.g. Grevelingenmeer) is daarbij een interpolatie uitgevoerd omdat de ondiepe delen zowel in de lodingen als in het algemeen hoogtebestand niet zijn meegenomen. Voor de gebieden die behoren tot het onderzoeksgebied van voorliggende studie (Haringvliet, Hollands Diep, Biesbosch, Spui en Dordtsche $\mathrm{Kil}$ ) is in de studie Samenhang in de Delta, geen interpolatie uitgevoerd. De gegevens zijn gebaseerd op een gebiedsdekkende dieptekaart die is verkregen van Deltares (Ysebaert et al., 2013a).

Voor alle varianten is gerekend met dezelfde dieptekaart. In de Figuur 21 en Figuur 22 van dit rapport is te zien dat er morfologische veranderingen optreden in het gebied als gevolg van Zandhonger, bagger- en graafwerkzaamheden en sedimentatie. De huidige sedimentatie is in de orde van 1 á $2 \mathrm{~cm}$ jaar ${ }^{-1}$ voor het Hollands Diep en 0,2 á $1 \mathrm{~cm}_{\text {jaar }}{ }^{-1}$ in het Grevelingenmeer. Toelaten van de getijslag en daarmee de stroomsnelheden als gevolg van de getijdenwerking zal de sedimentatie en erosieprocessen veranderen. De dieptekaart van het gebied in 2050 zal daarom niet dezelfde zijn als de kaart die in de huidige studie is gebruikt. Aanzanding van de geulen zal weinig effect hebben op de resultaten van deze studie. Morfologische veranderingen in de ondiepe zone en de droge en droogvallende delen zullen echter wel veel effecten hebben. In Figuur 31 is te zien dat er ook in deze zone tussen land en waterovergangen veranderingen zijn opgetreden in de periode 1985 - 2017. Een deel van deze veranderingen zijn het gevolg van natuurherstelprojecten en een deel van deze veranderingen zijn het gevolg van sedimentatie-erosie processen.

In deze studie is de Noordwaard buiten beschouwing gelaten. Het totaaloppervlakte van dit ontpolderde gebied is ongeveer 4550 ha, en bevat daarmee in potentie een aanzienlijk areaal aan intergetijdengebied. Met het toelaten van extra getij door de Haringvlietsluizen zal ook het intergetijdengebied in de Noordwaard veranderen. Om te onderzoeken hoe de getijdenatuur in de Noordwaard zal veranderen is aanvullend onderzoek nodig.

\section{Bodemsamenstelling}

Naast getijdynamiek en zoutgehalte zijn er nog een groot aantal parameters die van belang zijn voor de ontwikkeling van flora en fauna in een gebied. Een belangrijke factor is bijvoorbeeld de bodemsamenstelling. Het is bekend dat een slibrijke bodem een andere bodemdiergemeenschap herbergt dan een zandige bodem. In het ZES ecotopenstelsel voor zoute wateren (Bouma et al., 2005) is daarom een onderscheid tussen slibrijke en slibarme ecotopen. Ook de ontwikkeling van vegetatie is de bodemsamenstelling van belang. Dit heeft bijvoorbeeld een belangrijk effect op de waterhuishouding. In deze studie is de bodemsamenstelling niet meegenomen als factor voor de ecotopen.

\section{Vervuild slib}

$\mathrm{Na}$ de afsluiting is in het Haringvliet en Hollands Diep vervuild slib afgezet. In huidige situatie treedt erosie van slib alleen op onder invloed van golfwerking of hoge rivierafvoeren. Met een ander sluisbeheer bestaat het risico op toenemende erosie. Omdat het niet wenselijk is dat vervuild slib gaat eroderen en verspreiden, is hier tijdens de MER-studie een verkennend onderzoek naar uitgevoerd. Hieruit is gebleken dat met name voor de variant stormvloedkering de kans op de erosie van vervuild slib aanwezig is en dat deze variant naar verwachting niet zonder bodembeschermingsmaatregelen uitgevoerd kan worden. Of dit ook voor het $0,8 \mathrm{~cm}$ getij scenario geldt, verdient nader onderzoek.

\section{Zoutverspreiding}

Zout is een belangrijke factor voor het voorkomen van soorten en daarmee de natuurwaarde van ecotopen. In deze studie is een onderscheid gemaakt tussen brakwater (>0,5 ppt) en zoetwater (< $0,5 \mathrm{ppt}$ ). De grens tussen brak en zoetwater is in werkelijkheid echter niet statisch en zal zich dynamisch gedragen als gevolg van de getijwerking vanaf zee en de variërende rivierafvoer. Dit is een "natuurlijke" eigenschap van estuaria en delta's. Ook voor de sluiting van de Haringvlietdam varieerde de 0,5 ppt isocline van de Biesbosch bij hoog water op de Noordzee en een lage rivierafvoer tot bij Middelharnis bij laag water en een hoge rivierafvoer (Figuur 42). Het zijn juist de typisch brakwatersoorten die zich kunnen handhaven bij deze sterk fluctuerende omstandigheden. In deze studie is de grens tussen brakwater en zoetwater ecotopen gebaseerd op de ligging van de 0,5 ppt isocline bij hoogwater op de Noordzee tijdens gemiddelde rivierafvoer. Als gevolg van de getijdynamiek zal de grens dagelijks heen en weer migreren. 
Naast deze natuurlijke dynamiek zit er ook nog een grote onzekerheid in de ligging van de 0,5 ppt isocline. Zoals beschreven in dit rapport kan de zoutdynamiek in het Haringvliet nog niet goed worden beschreven met de huidige modellen. In onderhavige studie is er daarom voor gekozen om de zoutgrens in te schatten op basis van een deskundigen-oordeel, ondersteund met metingen uit de periode kort voor de sluiting van de Haringvlietdam. Hierdoor is er ook grote onzekerheid over de ligging van de 0,5 ppt isocline.

Punt van aandacht hierbij is het mogelijk optreden van stratificatie en de daaraan gekoppelde zuurstof deficiëntie (Wijsman, 2002). Doordat zout water een hogere dichtheid heeft dan zoet water kan er stratificatie optreden als zoet water en zout water samenkomen, waarbij zoet water "drijft" op het zoute water. Door de verminderde uitwisseling tussen de twee watermassa's en de zuurstofconsumptie bij de bodem door de afbraak van organisch materiaal kan er zuurstof deficiëntie optreden in het diepere water. Indien er zuurstofloosheid optreedt als gevolg van stratificatie zal dit waarschijnlijk weinig effect hebben op de ecotopen van de intergetijdengebieden. Dit omdat het voornamelijk de bovenste (zuurstofrijke) waterlaag is die de ecotopen zal overspoelen.

\section{Statistieken waterstandgegevens}

De ecotopen die gebruikt zijn in deze studie zijn voor een belangrijk deel gebaseerd op getijstatistieken (gemiddeld laag water, gemiddeld hoogwater in de zomer, gemiddeld hoogwater in de winter, hoogwater tijdens springtij in de winter en de maximale waterstand). Deze getijstatistieken zijn berekend uit de gemodelleerde waterstanden die met een 1D model zijn berekend over een periode van 10 jaar, waarbij het gemiddeld laagwater is berekend als het 5-percentiel van de waterstanden over de hele periode. Het gemiddeld hoogwater tijdens de zomer en het gemiddeld hoogwater in de winter is berekend uit de 95-percentielen van de waterstanden tijdens respectievelijk de zomerperioden ( 1 april tot 1 september) en de winterperioden ( 1 september tot 1 april). Hoogwater tijdens springtij in de winter is berekend uit het 99-percentiel van de waterstanden tijdens de winterperiode. De maximale waterstand ten slotte is de maximale waterstand die is berekend tijdens de gemodelleerde periode van 10 jaar.

De waterstanden in het gebied volgen niet een regelmatige getijcurve met een dagelijks getij en maandelijks springtij (zie bijvoorbeeld Figuur 41). De waterstanden worden in het model namelijk ook beïnvloed door windopzet op de Noordzee (bijvoorbeeld tijdens storm uit het Noordwesten) en rivierafvoer. Hierdoor kan het gebeuren dat er perioden zijn met verhoging (hoge rivierafvoer, NWstorm) of juist verlaging (lage rivierafvoer, wind uit zuiden) van de waterstanden. Dit is een fenomeen dat niet uitzonderlijk is voor getijderivieren, en is bijvoorbeeld ook gekend voor de Schelde (e.g. Taveniers et al., 2013). Door de fysieke aanwezigheid van de Haringvlietsluizen echter wordt het effect van veranderende rivierafvoer versterkt. Als gevolg hiervan varieert het middenpeil in het onderzoeksgebied sterk.

In Tabel 3 (§6.2.2) is te zien dat dat er over het algemeen een goede overeenkomst is tussen de gemiddelde getijslag (berekend over een periode van 24 uur en 50 minuten) en de getijslag zoals afgeleid uit de percentielen (verschil tussen GHW en GLW). Voor de winterperiode in de varianten Huidig beheer en $80 \mathrm{~cm}$ getij leidt de afleiding uit de percentielen wel tot een overschatting van de (gemiddelde) getijslag met respectievelijk 37 en $33 \mathrm{~cm}$. De verschillen zijn het gevolg van de variërende middenstand die wordt veroorzaakt door de variatie in rivierafvoer (en stormopzet) tijdens de winter. Voor de ecotopen is het van belang om het effect van de variërende middenstand mee te nemen en dus de arealen intergetijdengebieden te baseren op de benadering van de getijslag middels de percentielen, zoals gedaan is in voorliggende studie. Van belang daarbij is wel te realiseren dat de ecotopen in het intergetijdengebieden soms gedurende langere perioden (dagen tot weken) aaneengesloten onder water kunnen staan dan wel droog kunnen vallen.

Als een Permanent intergetijdengebied gedurende langere tijd (weken) droogvalt of juist niet droogval, zal dat consequenties hebben voor het bodemleven. Ook een verhoging van de waterstand tijdens de voege zomer kan consequenties hebben voor vogels die hebben genesteld in de buurt van de waterlijn. In Tabel 5 zijn op basis van de waterstandberekeningen voor locatie Rak Noord (centraal in modelgebied) voor iedere variant berekend wat de maximale tijd is dat een waterstand 
(gedefinieerd als HWS winter, GHWwinter, GHW zomer en GLW) ononderbroken wordt over (nat) en onderschreden (droog).

Tabel 5 Maximale periode (dagen) dat een bepaalde hoogtezone ononderbroken nat of droog is. Berekeningen zijn uitgevoerd voor de waterstanden van de locatie Rak Noord. $* * *$ is langer dan een hele winterperiode.

\begin{tabular}{|c|c|c|c|c|c|c|c|c|}
\hline \multirow[b]{2}{*}{ Statistiek } & \multicolumn{2}{|c|}{ Huidig/Kierbesluit } & \multicolumn{2}{|c|}{$80 \mathrm{~cm}$ getij } & \multicolumn{2}{|c|}{ Stormvloedkering } & \multicolumn{2}{|c|}{ Klimaatverandering } \\
\hline & Nat & Droog & Nat & Droog & Nat & Droog & Nat & Droog \\
\hline HWS winter & 0,9 & $* * *$ & 0,5 & $* * *$ & 0,3 & $* * *$ & 0,5 & $* * *$ \\
\hline $\mathrm{GHW}_{\text {winter }}$ & 2,4 & $* * *$ & 1,5 & 172,8 & 0,7 & 156 & 0,6 & 73,9 \\
\hline GHW zomer & 4,4 & 67,2 & 4,1 & 36,0 & 1,0 & 34,7 & 1,0 & 31,5 \\
\hline GLW & 153 & 2,5 & 80,2 & 0,96 & 42,8 & 0,4 & 37,2 & 0,4 \\
\hline
\end{tabular}

Tabel 5 is gebaseerd op de door het model berekende waterstanden voor de locatie Rak Noord. De getallen geven de maximale tijdsduur (dagen) dat de waterstand aaneengesloten hoger is dan de statistiek (Nat) of lager dan de statistiek (Droog). Bijvoorbeeld, een locatie op het aan de oever dat precies ligt op de gemiddelde hoogwaterstand in de zomer in de variant Stormvloedkering $(+86 \mathrm{~cm}$ NAP), valt gedurende de simulatieperiode (10 jaar) maximaal 34.7 dagen aaneengesloten droog tijdens de zomer. In Tabel 5 is ook te zien dat er jaren zijn dat de waterstand in de winter zo laag is dat de HWS winter en voor de variant Huidig beheer zelfs de GHW winter niet overschreden wordt.

De variërende middenstanden zijn karakteristiek voor getijdenrivieren zoals het onderzoeksgebied van deze studie en wordt niet, of in veel mindere mate, aangetroffen in gebieden als de Oosterschelde en de Westerschelde. De aanwezigheid van de barrièrewerking door de Haringvlietsluizen in relatie met variabele rivierafvoer en windopzet bij Hoek van Holland veroorzaakt deze variërende middenstand. Dit leidt ook tot een karakteristiek intergetijdengebied met andere natuurwaarden dan de intergetijdengebieden van de Oosterschelde en de Westerschelde.

\section{Natuurwaarden}

Algemeen kan gesteld worden dat bij elke onderzochte variant de biodiversiteit zal toenemen in het studiegebied, en dat het gebied weer een meer estuarien karakter krijgt, door introductie van zout water uit de Noordzee (alle varianten) en een vergroting van de getijslag (varianten $80 \mathrm{~cm}$ Getij, Stormvloedkering en Klimaatscenario). Door de verbinding met de Noordzee te herstellen zal vismigratie bevorderd worden, en zullen tevens brakwatergebieden ontstaan en zal het areaal intergetijdengebied toenemen. De grootste habitatdiversiteit lijkt te ontstaan in de variant Stormvloedkering. Welke natuur zich waar gaat ontwikkelen is op dit moment nog moeilijk in detail in te vullen, omwille van de grote onzekerheden in de zoutverdeling in het gebied, onzekerheden over nauwkeurigheid van de modellen en de dieptekaart en daarmee bijv. verdeling van de droogvalduur in de intergetijdengebieden, ontwikkelingen in nutriënten en primaire productie en de doorwerking in het voedselweb, etc. Er kan wel besloten worden dat zowel broedvogels van rietlanden zullen profiteren van de nieuwe situatie, en dat de ontstane slikken geschikte foerageergebieden zullen vormen voor steltlopers en watervogels.

Herstel van estuariene dynamiek wordt het meest gerealiseerd in de variant Stormvloedkering. De variant Klimaatscenario laat duidelijk zien dat zeespiegelstijging moet meegenomen in de verwachte ontwikkelingen op langere termijn en toekomstig beheer moet waar nodig hieraan aangepast worden.

Uiteraard moet gerealiseerd worden dat elk scenario ook leidt tot afname of verlies van bepaalde ecotopen of habitattypes, met de daarbij horende leefgemeenschappen. Welke natuur meer waarde heeft dan een andere is grotendeels een maatschappelijke keuze, maar kan wel onderbouwd worden door indicatoren zoals internationaal belang, zeldzaamheid, etc. 


\section{$8 \quad$ Kwaliteitsborging}

Wageningen Marine Research beschikt over een ISO 9001:2008 gecertificeerd kwaliteitsmanagementsysteem (certificaatnummer: 187378-2015-AQ-NLD-RvA). Dit certificaat is geldig tot 15 september 2018. De organisatie is gecertificeerd sinds 27 februari 2001. De certificering is uitgevoerd door DNV Certification B.V.

Het chemisch laboratorium te IJmuiden beschikt over een NEN-EN-ISO/IEC 17025:2005 accreditatie voor testlaboratoria met nummer L097. Deze accreditatie is geldig tot 1 april 2021 en is voor het eerst verleend op 27 maart 1997; deze accreditatie is verleend door de Raad voor Accreditatie. Het chemisch laboratorium heeft hierdoor aangetoond in staat te zijn op technisch bekwame wijze valide resultaten te leveren en te werken volgens de ISO17025 norm. De scope (L097) met de geaccrediteerde analysemethoden is te vinden op de website van de Raad voor Accreditatie (www.rva.nl).

Op grond van deze accreditatie is het kwaliteitskenmerk $\mathrm{Q}$ toegekend aan de resultaten van die componenten die op de scope staan vermeld, mits aan alle kwaliteitseisen is voldaan.. Het kwaliteitskenmerk $Q$ staat vermeld in de tabellen met de onderzoeksresultaten. Indien het kwaliteitskenmerk $\mathrm{Q}$ niet staat vermeld is de reden hiervan vermeld.

De kwaliteit van de analysemethoden wordt op verschillende manieren gewaarborgd. De juistheid van de analysemethoden wordt regelmatig getoetst door deelname aan ringonderzoeken waaronder die georganiseerd door QUASIMEME. Indien geen ringonderzoek voorhanden is, wordt een tweede lijnscontrole uitgevoerd. Tevens wordt bij iedere meetserie een eerstelijnscontrole uitgevoerd. Naast de lijnscontroles wordende volgende algemene kwaliteitscontroles uitgevoerd:

- Blanco onderzoek.

- Terugvinding (recovery).

- Interne standaard voor borging opwerkmethode.

- Injectie standard.

- Gevoeligheid.

Bovenstaande controles staan beschreven in Wageningen Marine Research werkvoorschrift ISW 2.10.2.105.

Indien gewenst kunnen gegevens met betrekking tot de prestatiekenmerken van de analysemethoden bij het chemisch laboratorium worden opgevraagd.

Indien sprake is van onbeheerste kwaliteit worden passende maatregelen genomen. 


\section{Literatuur}

Astma, J. (2011) Kabinetsstandpunt t.a.v. Besluit beheer Haringvlietsluizen, Ministerie van Infrastructuur en Milieu, Pages 8.

Baptist, M. J., I. De Mesel, L. C. P. M. Stuyt, R. Henkens, H. De Molenaar, J. W. M. Wijsman, N. Dankers and V. Kimmel (2007) Herstel van estuariene dynamiek in de zuidwestelijke Delta. IMARES, Report number: C119/07, 172 pages.

Becker, A. (2015) Sediment in (be)weging, Deel 2 (periode 2000-2012). Deltares, Report number: 1208925000-ZWS-0023. Advies Beheer Rivierbodem RMM.

Berends, K. D. (2015) SOBEK 3 model van de Rijns-Maasmonding - Modelbouw, kalibratie en verificatie. Deltares, Report number: 1209449-0004-ZWS-0015.

Boesch, D. F. (1977) A new look at the zonation of benthos along the estuarine gradient, Pages 245-266 in

B. C. Coull, ed. Ecology of Marine Benthos. Columbia, Sout Carolina, University of South Carolina Press.

Bouma, H., D. J. De Jong, F. Twisk and K. Wolfstein (2005) Zoute wateren Ecotopenstelsel (ZES. 1) Voor het in kaart brengen van het potentiële voorkomen van levensgemeenschappen in zoute en brakke rijkswateren. RIKZ, Report number: RIKZ/2005.024, 156 pages.

Buschman, F., M. Van der Wal, T. P. Stoutjesdijk, Q. Gao and A. P. Wiersma (2015) Herstel onderwateroevers Berenplaat. Analyse en evaluatie definitief ontwerp. Deltares, Report number: 1210913-000-ZWS-0009.

De Bruijn, C. and C. P. Van Der Zanden (2011) Voorkomen zoetwatervegetatie op Tiengemeten. Van Hall Larenstein, Report.

De Goederen, S., A. Bavelaar, P. Jacobs, M. Kraaijenveld, J. Ligtenberg and T. Visser (2006) Niet te zoet, niet te zout. HOP2008, een nieuw bedieningsprogramma voor de Haringvlietsluizen, Report number: RIZA-werkdocument 2006.045X.

De Leeuw, C. C. and J. J. G. M. Backx (2000) Naar een herstel van estuariene gradienten in Nederland: Een literatuurstudie naar de algemene ecologische principes van estuariene gradienten ten behoeve van herstelmaatregelen langs de Nederlandse kust. RIKZ, Report number: RIKZ/2000.044.

De Vet, P. L. M., B. C. Van Prooijen and Z. B. Wang (2017) The differences in morphological development between the intertidal flats of the eastern and Western Scheldt. Geomorphology 281: 31-42.

Dir Zuid Holland (1992) Geomorfologische kartering van het Haringvliet, Hollandsch Diep, Nieuwe Merwede en Amer, Report.

Elias, E. P. L., A. J. F. Van der Spek and M. Lazar (2016) The 'Voordelta', the contiguous ebb-tidal deltas in the SW Netherlands: large-scale morphological changes and sediment budget 1965-2013; Impacts of large-scale engineering. Netherlands Journal of Geosciences - Geologie en Mijnbouw 27: 233259.

Erdbrink, C. D. and T. H. G. Jongeling (2009) Trillingsmetingen aan schuiven van het sluizencomplex Haringvliet. Deltares, Report number: 1002093-000-ZWS-0002.

Fujisaki, A. (2016) SOBEK 3-model of Rijnmaasmonding 2015, Jaarlijkse Actualisatie Modellen Rijnmaasmonding 2015. Deltares, Report number: 1220072-004-ZWS-0004.

Griffioen, A. B., H. V. Winter and R. Van Hal (2017) Prognose visstand in en rond het Haringvliet na invoering van het Kierbesluit in 2018. Wageningen Marine Research, Report number: C081/17, 53 pages.

Hoitink, A. J. F., Z. B. Wang, B. Vermeulen, Y. Huismans and K. Kästner (2017) Tidal controls on river delta morphology. Nature Geoscience 10.

Houwing, E. J. and G. Blom (2001) Sedimenttransport en morfologische ontwikkeling van het noordelijk Deltabekken. RIZA, Report number: 2001.02143.

Huismans, Y. and O. Van Duin (2016) Advies beheer rivierbodem van de Rijn-Maasmonding. Deltares, Report number: 1208925-000-ZWS-0040 Advies Beheer Rivierbodem RMM.

Huismans, Y., G. Van Velzen, T. S. D. O'Mahony, G. J. C. M. Hoffmans and A. P. Wiersma (2016) Scour sole sevelopment in siver seds with sixed sand-slay-seat stratigraphy, ICSE Conference 2016. Oxford UK.

Hunink, J. and M. Hegnauer (2015) Update Deltascenario's nationaal water model. Deltares, Report number: 1220056-000-ZWS-0015.

Koopmans, H. (2017) The development of scour holes in tidal rivers with heterogeneous subsoil under anthropogenic influence, Deltares/ TUDelft. 
L\&O (1958) The Venice System for the Classification of Marine Waters According to Salinity. Limnology and Oceanography 3.

Mulder, J. M. P., J. Cleveringa, M. Taal, B. K. Van Wesenbeeck and F. Klijn (2010) Sedimentperspectief op de Zuidwestelijke Delta. Deltares, Report number: 1203404-000, 62 pages.

O'Brien, M. (1969) Equilibrium flow areas of inlets on sandy coasts. Journal of the Waterways and Harbors Division; Proceedings of the American Society of Civil Engineers 95 (WW1): 43-52.

Ottevanger, W. and R. Van Der Mark (2016) Morfodynamische modellering Rijn-Maasmonding. Deltares, Report number: 1208925-000-ZWS-0030. Advies Beheer Rivierbodem RMM.

Paalvast, P. (2016) monitoringsplan ecologie project Kierbesluit. Ecoconsult, Report number: 2016-01, 63 pages.

Platteeuw, M. and P. Cornelissen (2005) De Haringvlietsluizen op een Kier; wat doet dat voor de natuur? Effectbeschrijving van gedeeltelijke openstelling van de Haringvlietsluizen op instandhoudingsdoelen Natura 2000. RIZA, Report number: RIZA werkdocument 2005.150X, 16 pages.

Posthoorn, R. (2002) Inrichtingsplan Tiengemeten. RIZA, Report number: RIZA Werkdocument 2002.074x, 47 pages.

Remane, A. (1934) Die Brackwasserfauna. Verhandlungen Der Deutschen Zoologischen Gesellschaft 36: 3474.

Rijkswaterstaat (1998a) MER beheer Haringvlietsluizen. Over de grens van zout en zoet. Deelrapport 2b Morfologie en kwaliteit morfologie monding Haringvliet, Report number: 128, 117 pages.

Rijkswaterstaat (1998b) MER beheer Haringvlietsluizen. Over de grens van zout en zoet. Deelrapport 1 Water en zoutbeweging, Report, 211 pages.

Rijkswaterstaat (1998c) MER beheer Haringvlietsluizen. Over de grens van zout en zoet. Deelrapport 2c Morfologie en kwaliteit - Morfologie en kwaliteit binnengebied, Report, 77 pages.

Rijkswaterstaat (1998d) MER beheer Haringvlietsluizen. Over de grens van zout en zoet. Hoofdrapport, Report, 117 pages.

Sloff, C. J., A. Van Spijk, E. Stouthamer and A. S. Sieben (2013) Understanding and managing the morphology of branches incising into sand-clay deposits in the Dutch Rhine Delta. Intern. J. of Sed. Res. 28: 127-138.

Snippen, E., A. Fioole, H. Geelen, A. Kamsteeg, A. Van Spijk and T. Visser (2005) Sediment in (be)weging, sedimentbalans Rijn-Maasmonding periode 1990-2000. Rijkswaterstaat-RIZA, Report.

Stam, J. M. T., M. Groen and L. Walburg (2002) Haringvlietmonding: reconstructie van een afsluiting beschrijving, verklaring en modelaanpak van de effecten van de sluiting van de Haringvlietmonding 1970-2000. RIKZ, Report number: 2002.028. RIKZ.

Tangelder, M., K. Troost and T. Ysebaert (2012) Ecologische begrippen: Veerkracht en verwante begrippen in het kader van Beleid Ondersteuning Programmabureau Zuidwestelijke Delta. Wageningen IMARES, Report number: C068/12.

Tangelder, M., E. Winter and T. Ysebaert (2017) Ecologie van zoet-zout overgangen. Literatuurstudie en beoordeling van een scenario in het Volkerak-Zoommeer in het kader van Beleidsondersteuning voor het ministerie van Landbouw, Natuur en Voedselkwaliteit. Wageningen Marine Research, Report.

Taveniers, E., Y. Plancke and F. Mostaert (2013) MONEOS - jaarboek monitoring WL Basisboek. Overzicht monitoring hydrodynamiek en fysische parameters zoals door WL in het Scheldebekken gemeten Uitleggend basisboek met algemene situering, methodolodie en achtergrond. Waterbouwkundig Laboratorium, Report number: 12_070, 293 pages.

Thiessen, M., T. Van Der Kaaij and R. Plieger (2017) Project in uitvoering: 3D model Haringvliet. Deltares, Report number: 11200567

Van Der Molen, D. T. (2012) Referenties en maatlatten voor natuurlijke watertypen voor de kaderrichtlijn water 2015-2021. STOWA, Report number: 2012-31.

Van Der Sligte, R. (2012) Haringvlietsluizen als stormvloedkering. Effecten op de morfodynamiek van de rivierbodem. Deltares, Report number: Memo 1207032-003-VEB-0009.

Van der Werf, J., M. Boersema, T. Bouma, R. Schrijvershof, J. Stronkhorst, L. De Vet and T. Ysebaert (2016) Definitief ontwerp Roggenplaat suppletie. Centre of Expertise, Report, 93 pages.

Van der Werf, J. J., J. Reinders, A. Van Rooijen, H. Holzhauer and T. Ysebaert (2015) Evaluation of a tidal flat sediment nourishment as estuarine management measure. Oean \& Coastal Management 114: 77-87.

Van der Wijk, R. M. (2015) Modelschematisatie Rijnmaasmonding Baseline en WAQUA schematisatie j15_5v1 en beno15_5-v1. Deltares, Report number: 1207404-008-ZWS-0001.

Van Leeuwen, F., P. Jacobs and K. Storm (2004) Haringvlietsluizen op een kier. Effecten op natuur en gebruiksfuncties. Rijkswaterstaat, Report number: AP/2004.07, 52 pages.

Van Maren, D. S. and Z. B. Wang (2009) Morfologisch advies saneringsonderzoek Haringvliet. Deltares, Report number: 1002686. 
Wang, Z. B., D. S. Van Maren, P. X. Ding, S. L. Yang, B. C. Van Prooijen, P. L. M. De Vet, J. C. Winterwerp, H. J. De Vriend, M. J. F. Stive and Q. He (2015) Human impacts on morphodynamic thresholds in estuarine systems. Continental Shelf Research 111: 174-183.

Whitfield, A. K., M. Elliott, A. Basset, S. J. M. Blaber and R. J. West (2012) Paradigms in estuarine ecology A review of the Remane diagram with a suggested revised model for estuaries. Estuarine Coastal And Shelf Science 97: 78-90.

Wijsman, J. W. M. (2002) Stratificatie en zuurstofdeficiëntie in het Grevelingenmeer. RIKZ Middelburg, Report number: RIKZ/AB/2002.819X, 64 pages.

Wolff, W. J. (1973) The estuary as a habitat. An analysis of data on the soft-bottom macrofauna of teh estuarine area of the rivers Rhine, Meuse, and Scheldt. Zoologische verhandelingen 126: 3-242.

Ysebaert, T., M. Tangelder and J. W. M. Wijsman (2013a) Samenhang in de Delta, ontwikkelingsvarianten voor de Zuidwestelijke Delta: Ecologische ontwikkeling van habitats en levensgemeenschappen (deel 2). IMARES, Report number: C159/13, 64 pages.

Ysebaert, T., M. Tangelder, J. W. M. Wijsman and K. Troost (2013b) Samenhang in de Delta, ontwikkelingsvarianten voor de Zuidwestelijke Delta: Ecologische onderbouwing (deel 1). IMARES, Report number: C073/12, 46 pages.

Ysebaert, T., D. J. Van der Hoek, R. Wortelboer, J. W. M. Wijsman, M. Tangelder and A. J. Nolte (2016) Management options for restoring estuarine dynamics and implications for ecosystems: $A$ quantitative approach for the Southwest Delta in the Netherlands. Ocean and Coastal Management 121: 33-48.

Zijl, F., D. Kerkhoven, A. Z. Visser and T. Van Der Kaaij (2011) WAQUA-model Rijnmaasmonding: Modelopzet, kalibratie en verificatie. Deltares, Report number: 1202199-005-ZKS-0035. 


\section{Verantwoording}

Rapport C008/18

Projectnummer: 4313100062

Dit rapport is met grote zorgvuldigheid tot stand gekomen. De wetenschappelijke kwaliteit is intern getoetst door een collega-onderzoeker en het verantwoordelijk lid van het managementteam van Wageningen Marine Research

Akkoord:

Marijn Tangelder

Onderzoeker Delta ecologie

Handtekening:

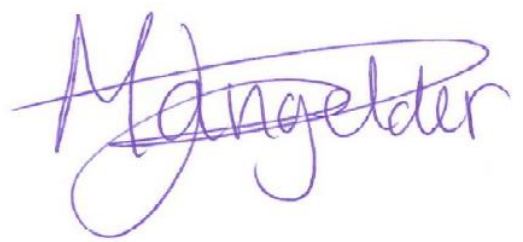

Datum: $\quad 31$ januari 2018

Akkoord:

Tammo Bult

Directeur Wageningen Marine Research

Handtekening:

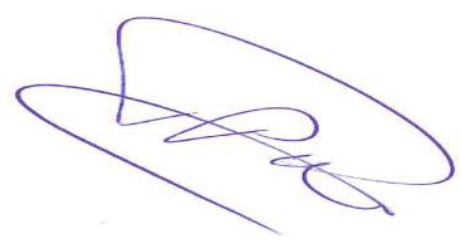

Datum:

31 januari 2018 


\section{Bijlage 1 Modelresultaten getijparameters Huidig beheer}

In onderstaande tabellen (Tabel 6, Tabel 7 en Tabel 8) staan de gemeten en de door het model berekende getijparameters voor de variant Huidige beheer. In Figuur 52 staan de cumulatieve verdelingen van de getijslag en de middenstand voor verschillende locaties in het onderzoeksgebied. In Figuur 53 en Figuur 54 zijn de door het model berekende getijparameters uitgezet tegen de afvoer bij Lobith en Figuur 55 Figuur 56 zijn deze afgezet tegen de waterstand bij Hoek van Holland.

Tabel 6 2000-2005 Gemeten getijparameters.

\begin{tabular}{l|llll|llll} 
& $\begin{array}{l}\text { Deene-plaat } \\
\text { Midden- } \\
\text { stand }\end{array}$ & $\begin{array}{l}\text { Moerdijk } \\
\text { Midden- } \\
\text { stand }\end{array}$ & $\begin{array}{l}\text { Hellevoet- } \\
\text { sluis } \\
\text { Midden- }\end{array}$ & $\begin{array}{l}\text { Zuidland } \\
\text { Midden- } \\
\text { stand }\end{array}$ & $\begin{array}{l}\text { Deene-plaat } \\
\text { Getijslag }\end{array}$ & $\begin{array}{l}\text { Moerdijk } \\
\text { Getijslag }\end{array}$ & $\begin{array}{l}\text { Hellevoet- } \\
\text { sluis } \\
\text { Getijslag }\end{array}$ & $\begin{array}{l}\text { Zuidland } \\
\text { Getijslag }\end{array}$ \\
Jan-Mar & 0,62 & 0,57 & 0,54 & 0,51 & 0,43 & 0,53 & 0,48 & 0,56 \\
\hline Apr-Jun & 0,49 & 0,45 & 0,44 & 0,33 & 0,32 & 0,39 & 0,39 & 0,45 \\
\hline Jul-Sep & 0,52 & 0,49 & 0,49 & 0,44 & 0,35 & 0,35 & 0,38 & 0,42 \\
\hline Okt-Dec & 0,61 & 0,56 & 0,57 & 0,53 & 0,40 & 0,42 & 0,43 & 0,47 \\
\hline Gem & $\mathbf{0 , 5 6}$ & $\mathbf{0 , 5 2}$ & $\mathbf{0 , 5 1}$ & $\mathbf{0 , 4 5}$ & $\mathbf{0 , 3 7}$ & $\mathbf{0 , 4 2}$ & $\mathbf{0 , 4 2}$ & $\mathbf{0 , 4 7}$ \\
\hline Max & $\mathbf{1 , 5 1}$ & $\mathbf{1 , 4 5}$ & $\mathbf{1 , 3 8}$ & $\mathbf{1 , 3 6}$ & $\mathbf{2 , 3 1}$ & $\mathbf{1 , 5 0}$ & $\mathbf{1 , 3 2}$ & $\mathbf{1 , 5 1}$ \\
\hline Min & $\mathbf{0 , 0 0}$ & $\mathbf{- 0 , 0 1}$ & $\mathbf{0 , 0 3}$ & $\mathbf{- 0 , 6 0}$ & $\mathbf{0 , 0 1}$ & $\mathbf{0 , 1 7}$ & $\mathbf{0 , 2 3}$ & $\mathbf{0 , 0 1}$ \\
\hline
\end{tabular}

Tabel 7 2000-2005 Modelresultaten Huidig beheer.

\begin{tabular}{|c|c|c|c|c|c|c|c|c|}
\hline & $\begin{array}{l}\text { Deene-plaat } \\
\text { Midden- } \\
\text { stand }\end{array}$ & $\begin{array}{l}\text { Moerdijk } \\
\text { Midden- } \\
\text { stand }\end{array}$ & $\begin{array}{l}\text { Hellevoet- } \\
\text { sluis } \\
\text { Midden- } \\
\text { stand }\end{array}$ & $\begin{array}{l}\text { Zuidland } \\
\text { Midden- } \\
\text { stand }\end{array}$ & $\begin{array}{l}\text { Deene-plaat } \\
\text { Getijslag }\end{array}$ & $\begin{array}{l}\text { Moerdijk } \\
\text { Getijslag }\end{array}$ & $\begin{array}{l}\text { Hellevoet- } \\
\text { sluis } \\
\text { Getijslag }\end{array}$ & $\begin{array}{l}\text { Zuidland } \\
\text { Getijslag }\end{array}$ \\
\hline Jan-Mar & 0,57 & 0,52 & 0,46 & 0,42 & 0,59 & 0,60 & 0,54 & 0,78 \\
\hline Apr-Jun & 0,44 & 0,41 & 0,39 & 0,34 & 0,46 & 0,46 & 0,44 & 0,65 \\
\hline Okt-Dec & 0,55 & 0,53 & 0,51 & 0,45 & 0,49 & 0,48 & 0,49 & 0,66 \\
\hline Gem & 0,51 & 0,49 & 0,46 & 0,41 & 0,49 & 0,49 & 0,47 & 0,67 \\
\hline Max & 1,5 & 1,43 & 1,32 & 1,32 & 1,58 & 1,65 & 1,59 & 1,8 \\
\hline Min & $-0,01$ & $-0,06$ & $-0,1$ & $-0,15$ & 0,25 & 0,25 & 0,28 & 0,36 \\
\hline
\end{tabular}

Tabel 8 Verschil berekend en gemeten 2000-2005 (Berekend - Gemeten getijparameters).

\begin{tabular}{|c|c|c|c|c|c|c|c|c|}
\hline & $\begin{array}{l}\text { Deene-plaat } \\
\text { Midden- } \\
\text { stand }\end{array}$ & $\begin{array}{l}\text { Moerdijk } \\
\text { Midden- } \\
\text { stand }\end{array}$ & $\begin{array}{l}\text { Hellevoet- } \\
\text { sluis } \\
\text { Midden- } \\
\text { stand }\end{array}$ & $\begin{array}{l}\text { Zuidland } \\
\text { Midden- } \\
\text { stand }\end{array}$ & $\begin{array}{l}\text { Deene-plaat } \\
\text { Getijslag }\end{array}$ & $\begin{array}{l}\text { Moerdijk } \\
\text { Getijslag }\end{array}$ & $\begin{array}{l}\text { Hellevoet- } \\
\text { sluis } \\
\text { Getijslag }\end{array}$ & $\begin{array}{l}\text { Zuidland } \\
\text { Getijslag }\end{array}$ \\
\hline Jan-Mar & $-0,05$ & $-0,05$ & $-0,08$ & $-0,09$ & 0,16 & 0,07 & 0,06 & 0,22 \\
\hline Apr-Jun & $-0,05$ & $-0,04$ & $-0,05$ & 0,01 & 0,14 & 0,07 & 0,05 & 0,2 \\
\hline Okt-Dec & $-0,06$ & $-0,03$ & $-0,06$ & $-0,08$ & 0,09 & 0,06 & 0,06 & 0,19 \\
\hline Gem & $-0,05$ & $-0,03$ & $-0,05$ & $-0,04$ & 0,12 & 0,07 & 0,05 & 0,2 \\
\hline Max & $-0,01$ & $-0,02$ & $-0,06$ & $-0,04$ & $-0,73$ & 0,15 & 0,27 & 0,29 \\
\hline Min & $-0,01$ & $-0,05$ & $-0,13$ & 0,45 & 0,24 & 0,08 & 0,05 & 0,35 \\
\hline
\end{tabular}



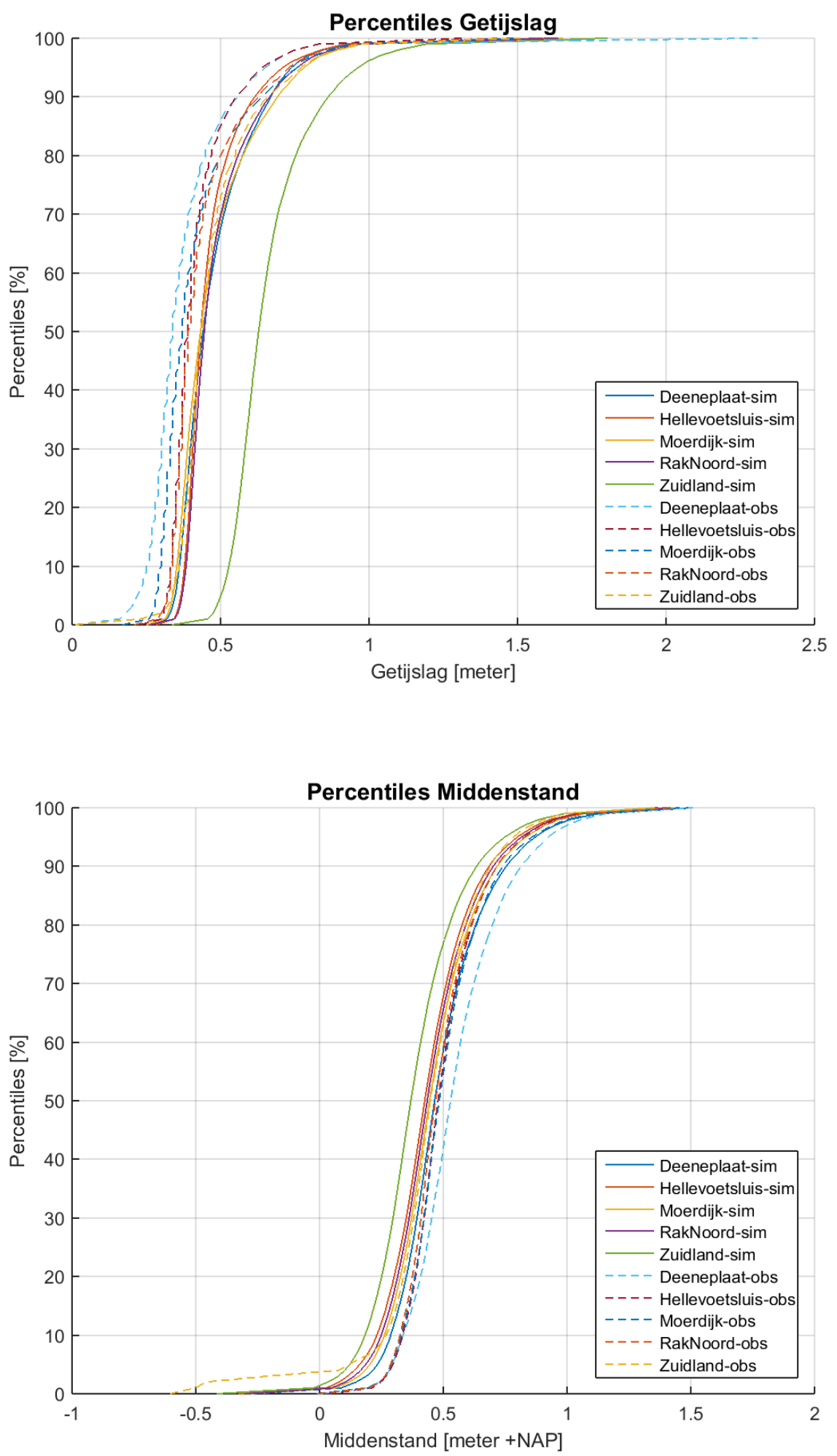

Figuur 52 Percentiel figuren voor gemeten en gesimuleerde getijparameters tussen 2000 en 2005 . 

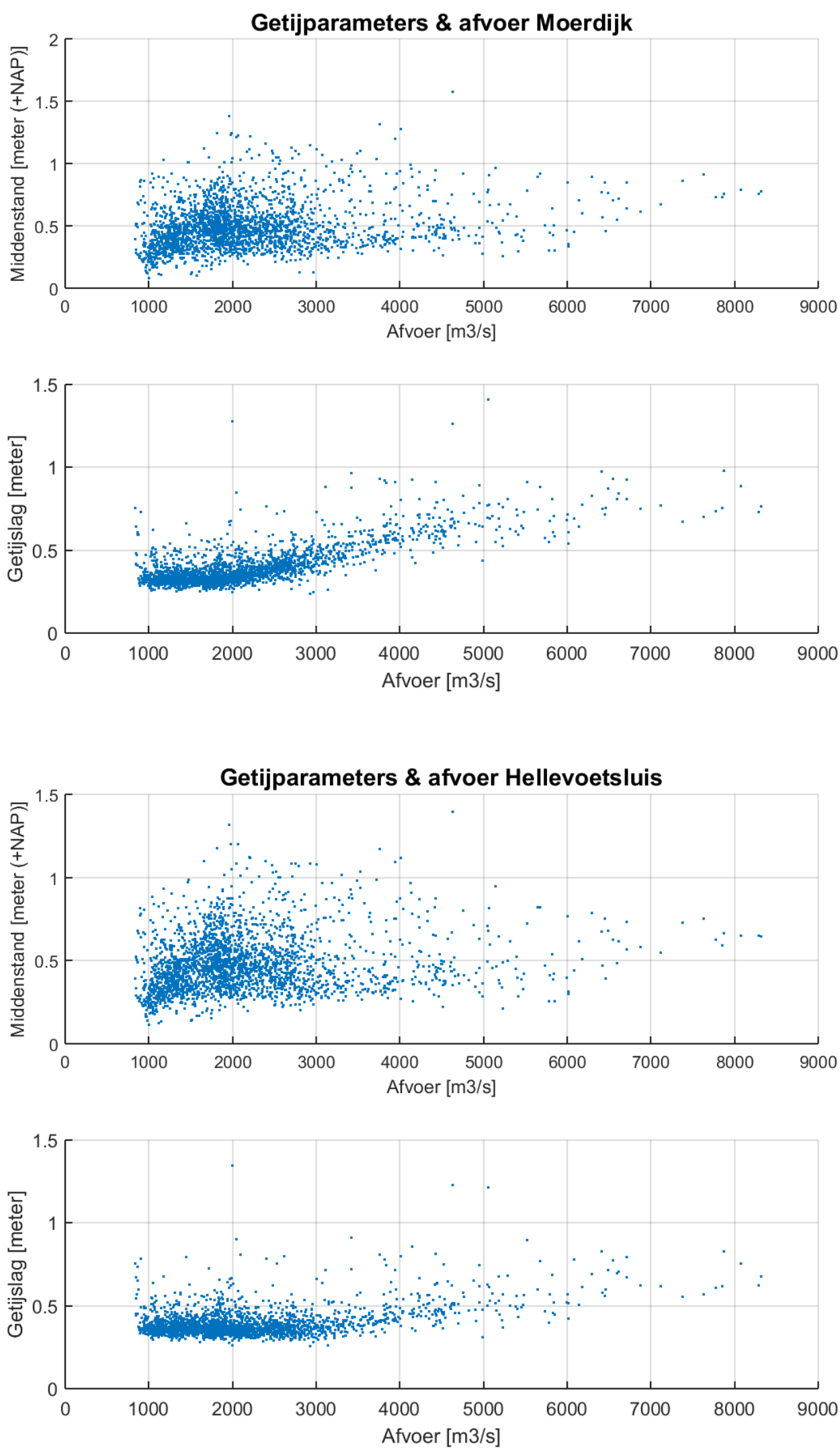

Figuur 53 Getijparameters Moerdijk en Hellevoetsluis uitgezet tegen de afvoer bij Lobith. 

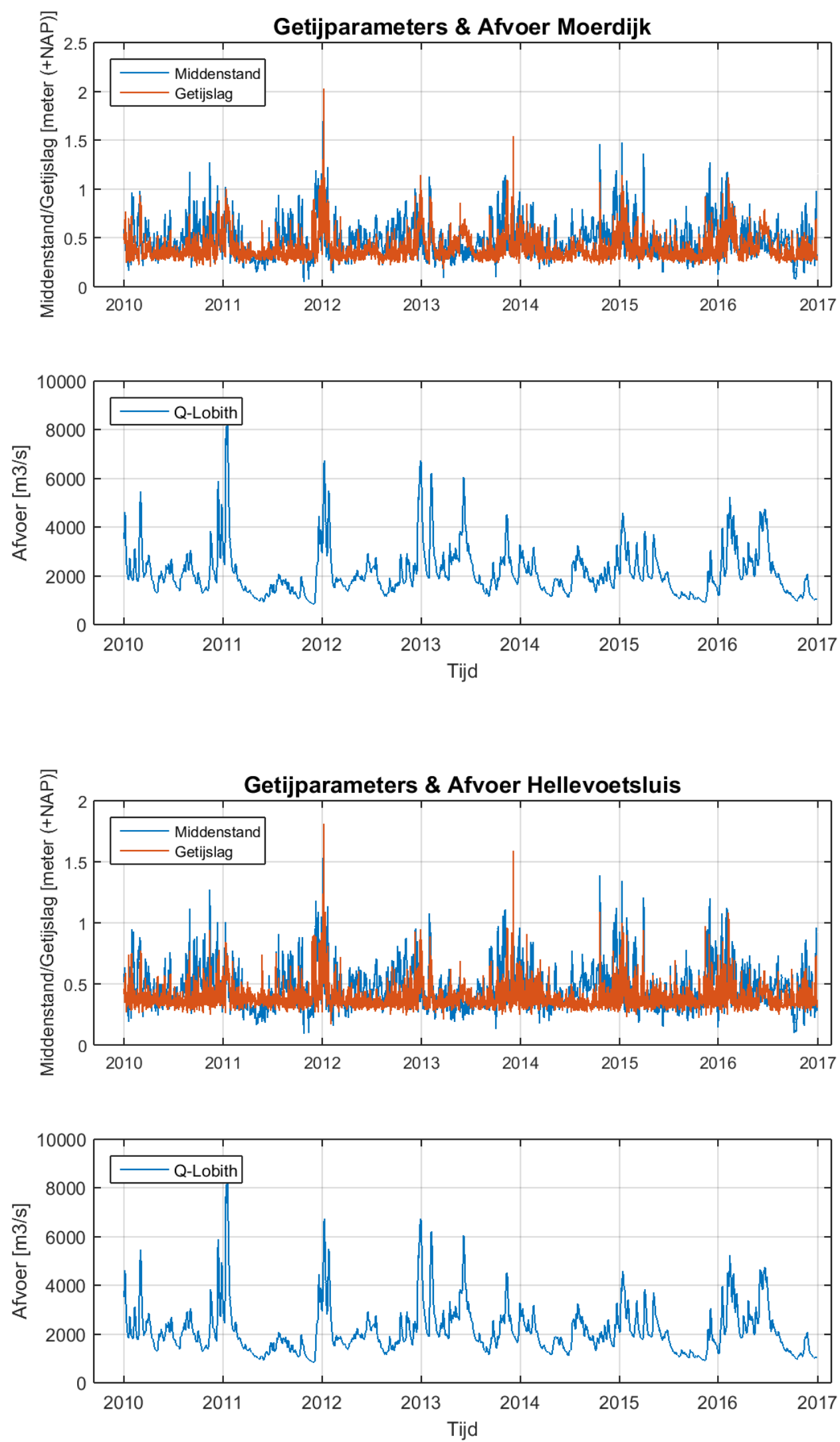

Figuur 54 Getijparameters uitgezet tegenover de afvoer bij Lobith. 

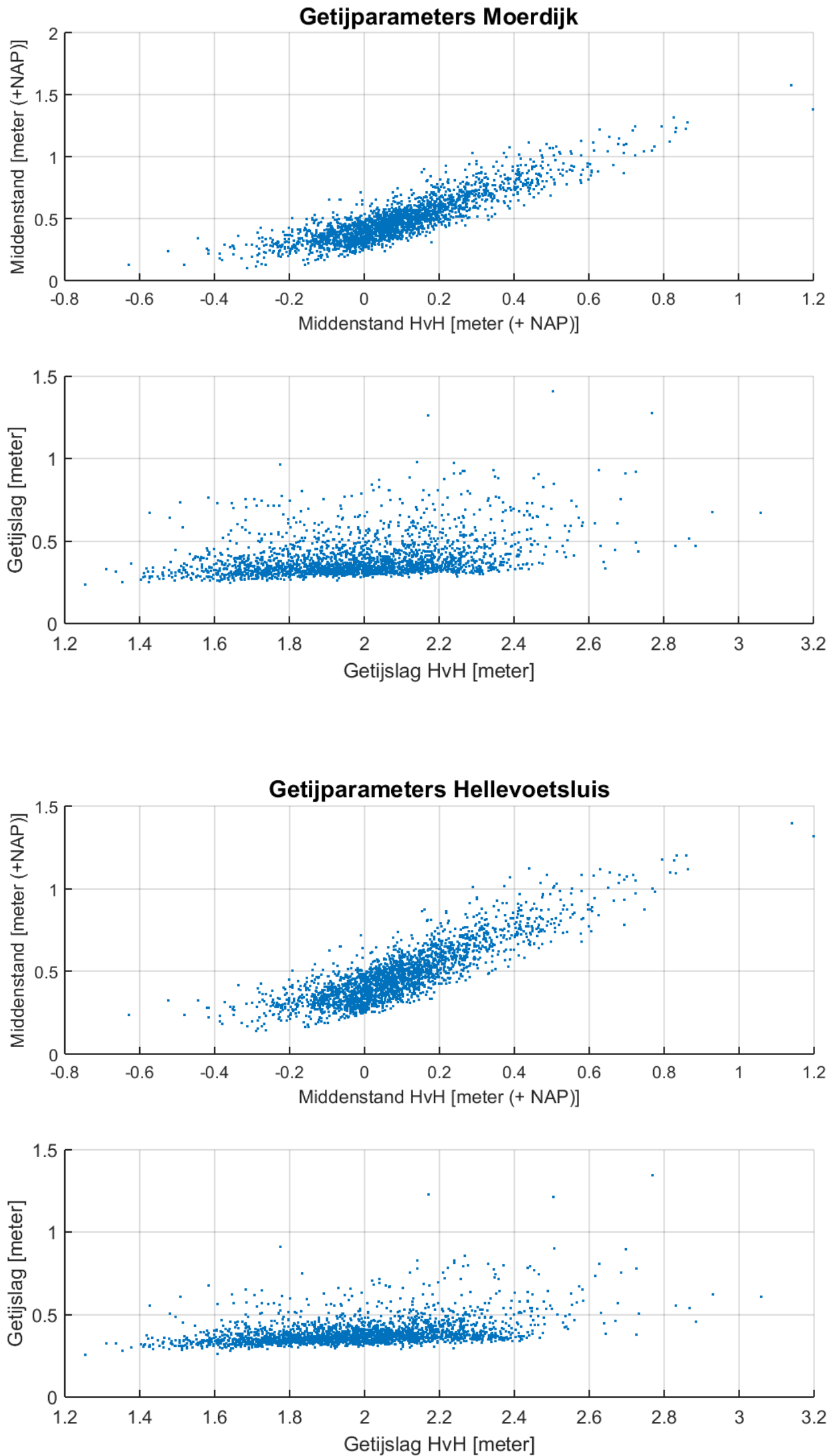

Figuur 55 Getijparameters Moerdijk en Hellevoetsluis uitgezet tegenover de getijparameters bij Hoek van Holland. 

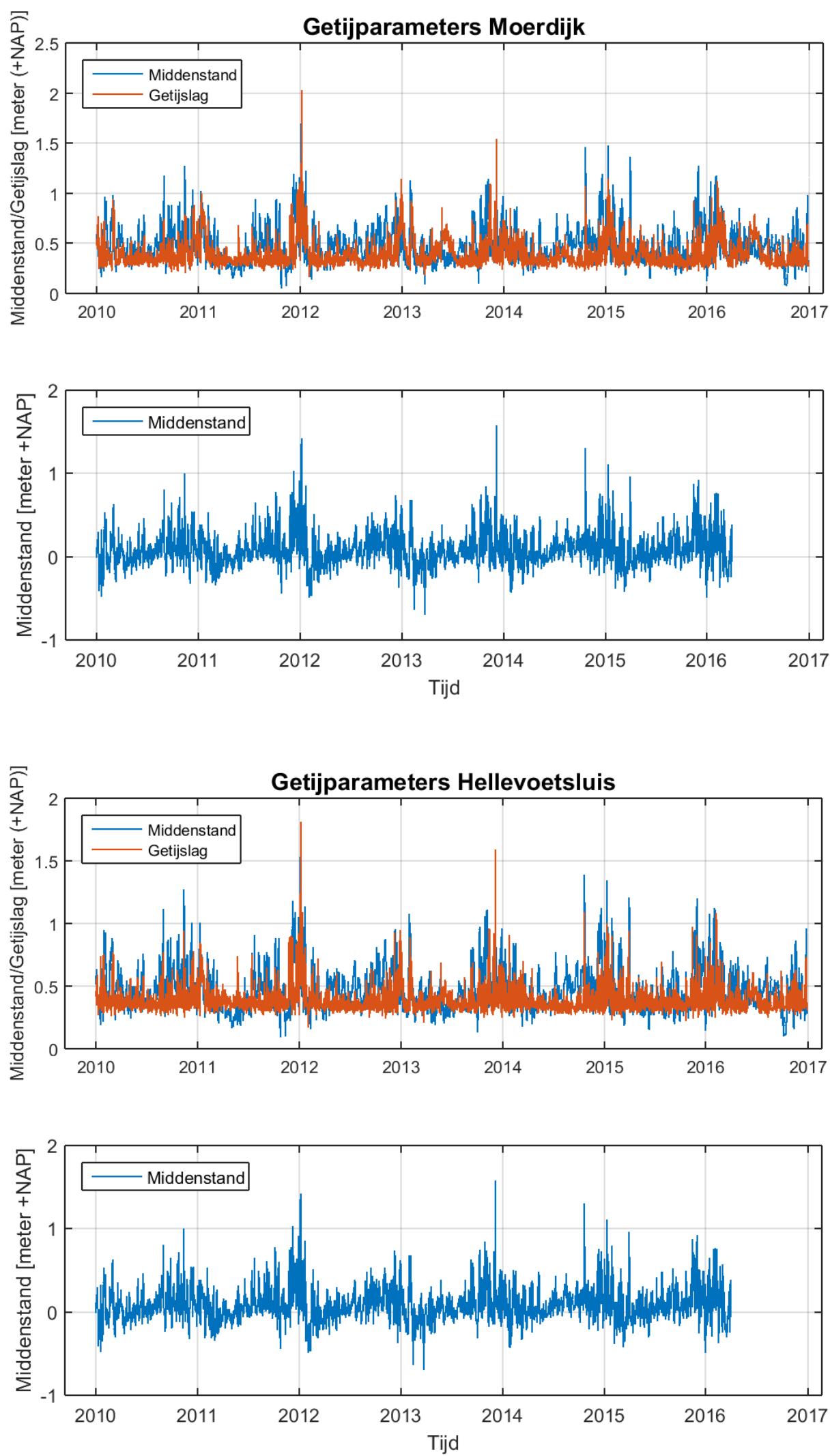

Figuur 56 Getijparameters uitgezet tegenover de waterstand bij Hoek van Holland. 


\section{Bijlage 2 Modelresultaten getijparameters $80 \mathrm{~cm}$ getij}

In Tabel 9 staan de door het model berekende getijparameters voor de variant $80 \mathrm{~cm}$ getij. Tabel 10 geeft het verschil in de getijparameters tussen de variant $80 \mathrm{~cm}$ getij en de variant Huidig beheer. In Figuur 57 staan de cumulatieve verdelingen van de getijslag en de middenstand voor verschillende locaties in het onderzoeksgebied voor de variant $80 \mathrm{~cm}$ getij.

\begin{tabular}{|c|c|c|c|c|c|c|c|c|}
\hline & $\begin{array}{l}\text { Deene-plaat } \\
\text { Midden- } \\
\text { stand }\end{array}$ & $\begin{array}{l}\text { Moerdijk } \\
\text { Midden- } \\
\text { stand }\end{array}$ & $\begin{array}{l}\text { Hellevoet- } \\
\text { sluis } \\
\text { Midden- } \\
\text { stand }\end{array}$ & $\begin{array}{l}\text { Zuidland } \\
\text { Midden- } \\
\text { stand }\end{array}$ & $\begin{array}{l}\text { Deene-plaat } \\
\text { Getijslag }\end{array}$ & $\begin{array}{l}\text { Moerdijk } \\
\text { Getijslag }\end{array}$ & $\begin{array}{l}\text { Hellevoet- } \\
\text { sluis } \\
\text { Getijslag }\end{array}$ & $\begin{array}{l}\text { Zuidland } \\
\text { Getijslag }\end{array}$ \\
\hline Jan-Mar & 0,54 & 0,47 & 0,38 & 0,36 & 1,01 & 1,02 & 0,82 & 1,11 \\
\hline Apr-Jun & 0,33 & 0,29 & 0,23 & 0,22 & 1,01 & 1,01 & 0,78 & 1,07 \\
\hline Jul-Sep & 0,34 & 0,31 & 0,26 & 0,26 & 1,01 & 0,99 & 0,77 & 1,04 \\
\hline Okt-Dec & 0,41 & 0,38 & 0,32 & 0,31 & 1,05 & 1,04 & 0,82 & 1,10 \\
\hline Gem & 0,40 & 0,36 & 0,30 & 0,29 & 1,02 & 1,01 & 0,80 & 1,08 \\
\hline Max & 1,62 & 1,50 & 1,41 & 1,41 & 2,10 & 2,09 & 1,91 & 2,15 \\
\hline Min & $-0,32$ & $-0,38$ & $-0,45$ & $-0,46$ & 0,50 & 0,55 & 0,47 & 0,65 \\
\hline
\end{tabular}

Tabel 10 Verschil varianten $80 \mathrm{~cm}$ getij en Huidig beheer $(80 \mathrm{~cm}$ getij - Huidig beheer).

\begin{tabular}{l|llll|llll} 
& $\begin{array}{l}\text { Deene-plaat } \\
\text { Midden- } \\
\text { stand }\end{array}$ & $\begin{array}{l}\text { Moerdijk } \\
\text { Midden- } \\
\text { stand }\end{array}$ & $\begin{array}{l}\text { Hellevoet- } \\
\text { sluis } \\
\text { Midden- }\end{array}$ & $\begin{array}{l}\text { Zuidland } \\
\text { Midden- } \\
\text { stand }\end{array}$ & $\begin{array}{l}\text { Deene-plaat } \\
\text { Getijslag }\end{array}$ & $\begin{array}{l}\text { Moerdijk } \\
\text { Getijslag }\end{array}$ & $\begin{array}{l}\text { Hellevoet- } \\
\text { sluis } \\
\text { Getijslag }\end{array}$ \\
\hline Jan-Mar & $-0,03$ & $-0,05$ & $-0,08$ & $-0,06$ & 0,42 & 0,42 & 0,28 & 0,33 \\
\hline Jul-Sep & $-0,11$ & $-0,12$ & $-0,16$ & $-0,12$ & 0,55 & 0,55 & 0,34 & 0,42 \\
\hline Okt-Dec & $-0,14$ & $-0,15$ & $-0,19$ & $-0,14$ & 0,56 & 0,56 & 0,34 & 0,45 \\
\hline Gem & $-0,11$ & $-0,13$ & $-0,16$ & $-0,12$ & 0,53 & 0,52 & 0,33 & 0,44 \\
\hline Max & 0,12 & 0,07 & 0,09 & 0,09 & 0,52 & 0,44 & 0,32 & 0,41 \\
\hline Min & $-0,31$ & $-0,32$ & $-0,35$ & $-0,31$ & 0,25 & 0,30 & 0,19 \\
\hline
\end{tabular}



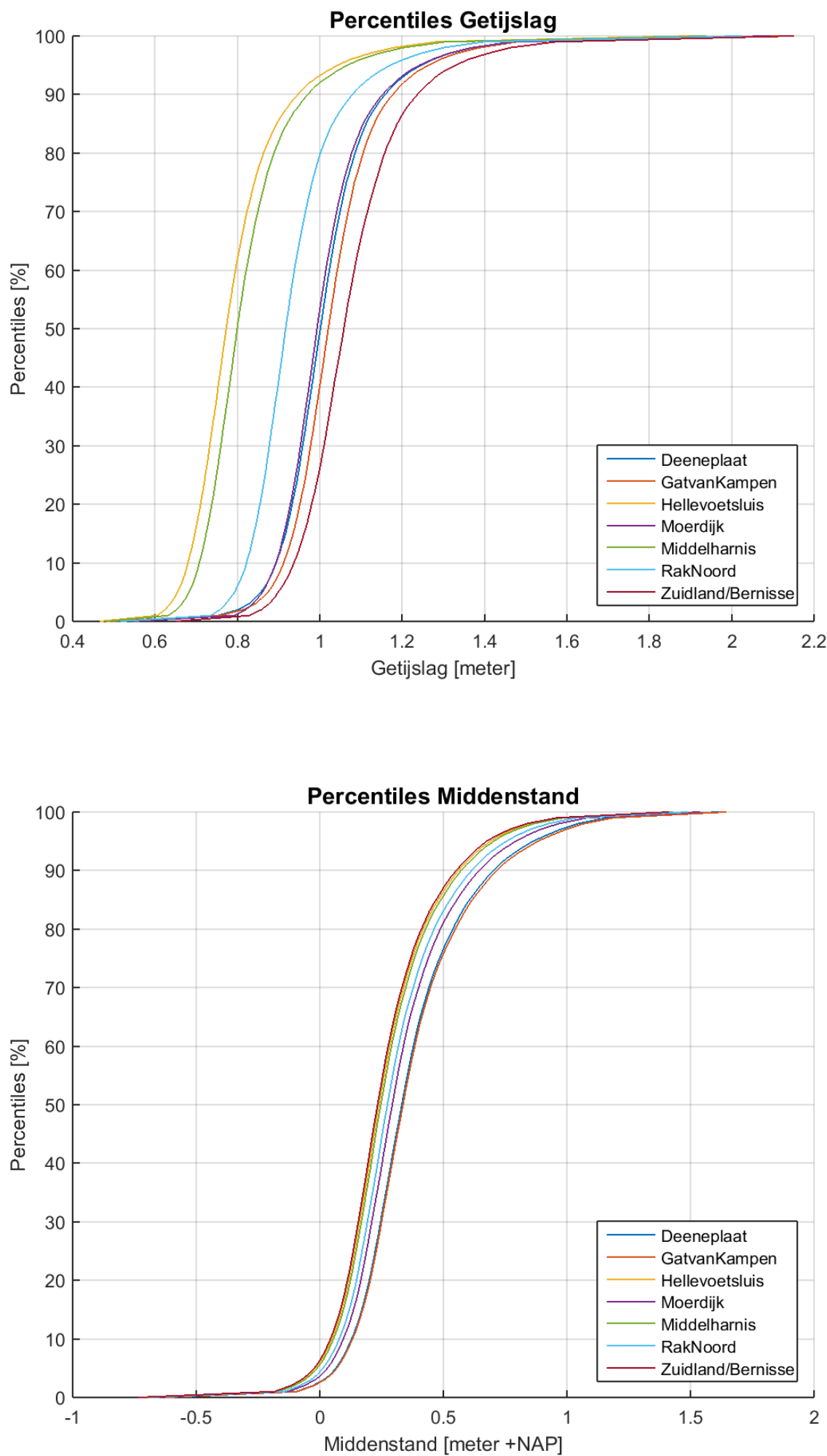

Figuur 57 Percentielen van getijparameters voor het de variant $80 \mathrm{~cm}$ getij. 


\section{Bijlage 3 Modelresultaten getijparameters Stormvloedkering}

In Tabel 12 staan de door het model berekende getijparameters voor de variant Stormvloedkering. Tabel 13 geeft het verschil in de getijparameters tussen de variant Stormvloedkering en de variant Huidig beheer. In Figuur 58 staan de cumulatieve verdelingen van de getijslag en de middenstand voor verschillende locaties in het onderzoeksgebied voor de variant Stormvloedkering.

Tabel 11 2000-2005 Modelresultaten variant Stormvloedkering.

\begin{tabular}{l|llll|llll} 
& $\begin{array}{l}\text { Deene-plaat } \\
\text { Midden- } \\
\text { stand }\end{array}$ & $\begin{array}{l}\text { Moerdijk } \\
\text { Midden- } \\
\text { stand }\end{array}$ & $\begin{array}{l}\text { Hellevoet- } \\
\text { sluis } \\
\text { Midden- }\end{array}$ & $\begin{array}{l}\text { Zuidland } \\
\text { Midden- } \\
\text { stand }\end{array}$ & $\begin{array}{l}\text { Deene-plaat } \\
\text { Getijslag }\end{array}$ & $\begin{array}{l}\text { Moerdijk } \\
\text { Getijslag }\end{array}$ & $\begin{array}{l}\text { Hellevoet- } \\
\text { sluis } \\
\text { Getijslag }\end{array}$ & $\begin{array}{l}\text { Zuidland } \\
\text { Getijslag }\end{array}$ \\
Jan-Mar & 0,52 & 0,44 & 0,29 & 0,31 & 1,33 & 1,36 & 1,33 & 1,44 \\
\hline Apr-Jun & 0,33 & 0,28 & 0,19 & 0,20 & 1,34 & 1,34 & 1,29 & 1,39 \\
\hline Jul-Sep & 0,34 & 0,30 & 0,25 & 0,25 & 1,33 & 1,32 & 1,27 & 1,36 \\
\hline Okt-Dec & 0,41 & 0,37 & 0,29 & 0,29 & 1,37 & 1,37 & 1,33 & 1,42 \\
\hline Gem & $\mathbf{0 , 4 0}$ & $\mathbf{0 , 3 5}$ & $\mathbf{0 , 2 5}$ & $\mathbf{0 , 2 6}$ & $\mathbf{1 , 3 4}$ & $\mathbf{1 , 3 5}$ & $\mathbf{1 , 3 0}$ & $\mathbf{1 , 4 0}$ \\
\hline Max & $\mathbf{1 , 5 8}$ & $\mathbf{1 , 4 8}$ & $\mathbf{1 , 2 6}$ & $\mathbf{1 , 3 2}$ & $\mathbf{2 , 3 7}$ & $\mathbf{2 , 4 0}$ & $\mathbf{2 , 4 2}$ & $\mathbf{2 , 5 6}$ \\
\hline Min & $\mathbf{- 0 , 2 6}$ & $\mathbf{- 0 , 3 7}$ & $\mathbf{- 0 , 4 5}$ & $\mathbf{- 0 , 4 2}$ & $\mathbf{0 , 7 6}$ & $\mathbf{0 , 8 3}$ & $\mathbf{0 , 7 7}$ & $\mathbf{0 , 8 6}$ \\
\hline
\end{tabular}

Tabel 12 Verschil varianten Stormvloedkering en Huidig beheer (Stormvloedkering Huidig beheer).

\begin{tabular}{|c|c|c|c|c|c|c|c|c|}
\hline & $\begin{array}{l}\text { Deene-plaat } \\
\text { Midden- } \\
\text { stand }\end{array}$ & $\begin{array}{l}\text { Moerdijk } \\
\text { Midden- } \\
\text { stand }\end{array}$ & $\begin{array}{l}\text { Hellevoet- } \\
\text { sluis } \\
\text { Midden- } \\
\text { stand }\end{array}$ & $\begin{array}{l}\text { Zuidland } \\
\text { Midden- } \\
\text { stand }\end{array}$ & $\begin{array}{l}\text { Deene-plaat } \\
\text { Getijslag }\end{array}$ & $\begin{array}{l}\text { Moerdijk } \\
\text { Getijslag }\end{array}$ & $\begin{array}{l}\text { Hellevoet- } \\
\text { sluis } \\
\text { Getijslag }\end{array}$ & $\begin{array}{l}\text { Zuidland } \\
\text { Getijslag }\end{array}$ \\
\hline Jan-Mar & $-0,05$ & $-0,08$ & $-0,17$ & $-0,11$ & 0,74 & 0,76 & 0,79 & 0,66 \\
\hline Apr-Jun & $-0,11$ & $-0,13$ & $-0,2$ & $-0,14$ & 0,88 & 0,88 & 0,85 & 0,74 \\
\hline Okt-Dec & $-0,14$ & $-0,16$ & $-0,22$ & $-0,16$ & 0,88 & 0,89 & 0,84 & 0,76 \\
\hline Gem & $-0,11$ & $-0,14$ & $-0,21$ & $-0,15$ & 0,85 & 0,86 & 0,83 & 0,73 \\
\hline Max & 0,08 & 0,05 & $-0,06$ & 0 & 0,79 & 0,75 & 0,83 & 0,76 \\
\hline Min & $-0,25$ & $-0,31$ & $-0,35$ & $-0,27$ & 0,51 & 0,58 & 0,49 & 0,5 \\
\hline
\end{tabular}



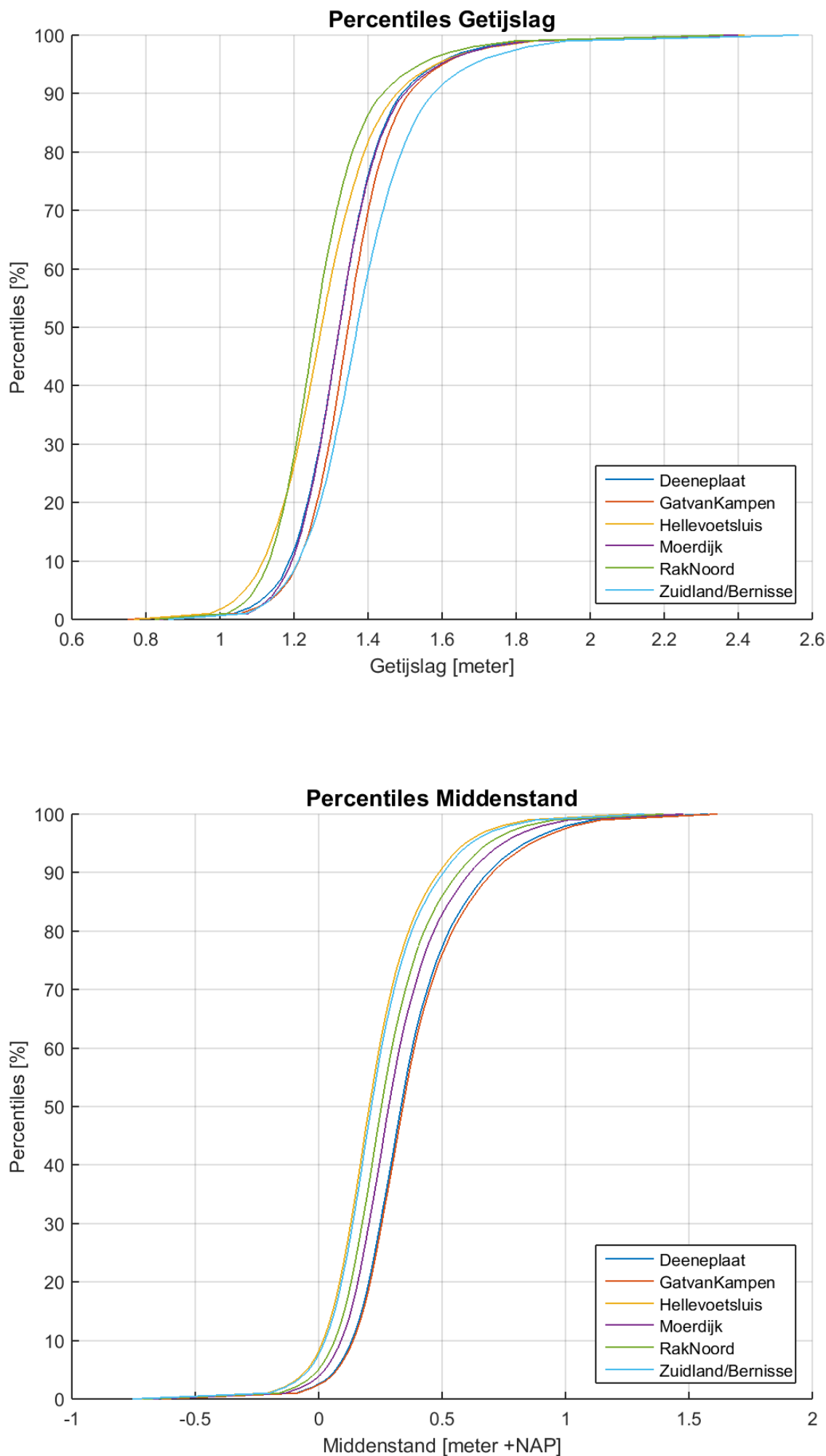

Figuur 58 Percentielen van getijparameters voor de variant stormvloedkering. 


\section{Bijlage 4 Modelresultaten getijparameters Klimaatscenario}

In Tabel 13 staan de door het model berekende getijparameters voor de variant Klimaatscenario. Tabel 14 geeft het verschil in de getijparameters tussen de variant Klimaatscenario en de variant Stormvloedkering. In Figuur 59 staan de cumulatieve verdelingen van de getijslag en de middenstand voor verschillende locaties in het onderzoeksgebied voor de variant Klimaatscenario.

Tabel 13 2000-2005 Modelresultaten variant Klimaatscenario.

\begin{tabular}{l|llll|llll}
\multicolumn{2}{c}{$\begin{array}{l}\text { Deene-plat } \\
\text { Midden- } \\
\text { stand }\end{array}$} & $\begin{array}{l}\text { Moerdijk } \\
\text { Midden- } \\
\text { stand }\end{array}$ & $\begin{array}{l}\text { Hellevoet- } \\
\text { sluis } \\
\text { Midden- }\end{array}$ & $\begin{array}{l}\text { Zuidland } \\
\text { Midden- } \\
\text { stand }\end{array}$ & $\begin{array}{l}\text { Deene-plat } \\
\text { Getijslag }\end{array}$ & $\begin{array}{l}\text { Moerdijk } \\
\text { Getijslag }\end{array}$ & $\begin{array}{l}\text { Hellevoet- } \\
\text { sluis } \\
\text { Getijslag }\end{array}$ & $\begin{array}{l}\text { Zuidland } \\
\text { Getijslag }\end{array}$ \\
Jan-Mar & 0,86 & 0,78 & 0,64 & 0,65 & 1,36 & 1,39 & 1,39 & 1,50 \\
\hline Apr-Jun & 0,68 & 0,63 & 0,56 & 0,56 & 1,40 & 1,41 & 1,37 & 1,47 \\
\hline Jul-Sep & 0,67 & 0,65 & 0,60 & 0,60 & 1,37 & 1,37 & 1,34 & 1,43 \\
\hline Okt-Dec & 0,75 & 0,71 & 0,64 & 0,64 & 1,40 & 1,40 & 1,38 & 1,48 \\
\hline Gem & $\mathbf{0 , 7 4}$ & $\mathbf{0 , 6 9}$ & $\mathbf{0 , 6 1}$ & $\mathbf{0 , 6 1}$ & $\mathbf{1 , 3 8}$ & $\mathbf{1 , 3 9}$ & $\mathbf{1 , 3 7}$ & $\mathbf{1 , 4 7}$ \\
\hline Max & $\mathbf{1 , 7 8}$ & $\mathbf{1 , 6 9}$ & $\mathbf{1 , 5 1}$ & $\mathbf{1 , 5 6}$ & $\mathbf{2 , 2 6}$ & $\mathbf{2 , 3}$ & $\mathbf{2 , 3}$ & $\mathbf{2 , 4 6}$ \\
\hline Min & $\mathbf{0 , 0 8}$ & $\mathbf{0 , 0 2}$ & $\mathbf{- 0 , 0 7}$ & $\mathbf{- 0 , 1 2}$ & $\mathbf{0 , 8 3}$ & $\mathbf{0 , 8 5}$ & $\mathbf{0 , 8 3}$ & $\mathbf{0 , 9 4}$ \\
\hline
\end{tabular}

Tabel 14 Verschil varianten Klimaatscenario en Stormvloedkering (Klimaatscenario Stormvloedkering).

\begin{tabular}{|c|c|c|c|c|c|c|c|c|}
\hline & $\begin{array}{l}\text { Deene-plaat } \\
\text { Midden- } \\
\text { stand }\end{array}$ & $\begin{array}{l}\text { Moerdijk } \\
\text { Midden- } \\
\text { stand }\end{array}$ & $\begin{array}{l}\text { Hellevoet- } \\
\text { sluis } \\
\text { Midden- } \\
\text { stand }\end{array}$ & $\begin{array}{l}\text { Zuidland } \\
\text { Midden- } \\
\text { stand }\end{array}$ & $\begin{array}{l}\text { Deene-plaat } \\
\text { Getijslag }\end{array}$ & $\begin{array}{l}\text { Moerdijk } \\
\text { Getijslag }\end{array}$ & $\begin{array}{l}\text { Hellevoet- } \\
\text { sluis } \\
\text { Getijslag }\end{array}$ & $\begin{array}{l}\text { Zuidland } \\
\text { Getijslag }\end{array}$ \\
\hline Jan-Mar & 0,34 & 0,34 & 0,35 & 0,34 & 0,03 & 0,03 & 0,06 & 0,06 \\
\hline Apr-Jun & 0,35 & 0,35 & 0,37 & 0,36 & 0,06 & 0,07 & 0,08 & 0,08 \\
\hline Jul-Sep & 0,33 & 0,35 & 0,35 & 0,35 & 0,04 & 0,05 & 0,07 & 0,07 \\
\hline Okt-Dec & 0,34 & 0,34 & 0,35 & 0,35 & 0,03 & 0,03 & 0,05 & 0,06 \\
\hline Gem & 0,34 & 0,34 & 0,36 & 0,35 & 0,04 & 0,04 & 0,07 & 0,07 \\
\hline Max & 0,20 & 0,21 & 0,25 & 0,24 & $-0,11$ & $-0,10$ & $-0,12$ & $-0,10$ \\
\hline Min & 0,34 & 0,39 & 0,38 & 0,30 & 0,07 & 0,02 & 0,06 & 0,08 \\
\hline
\end{tabular}



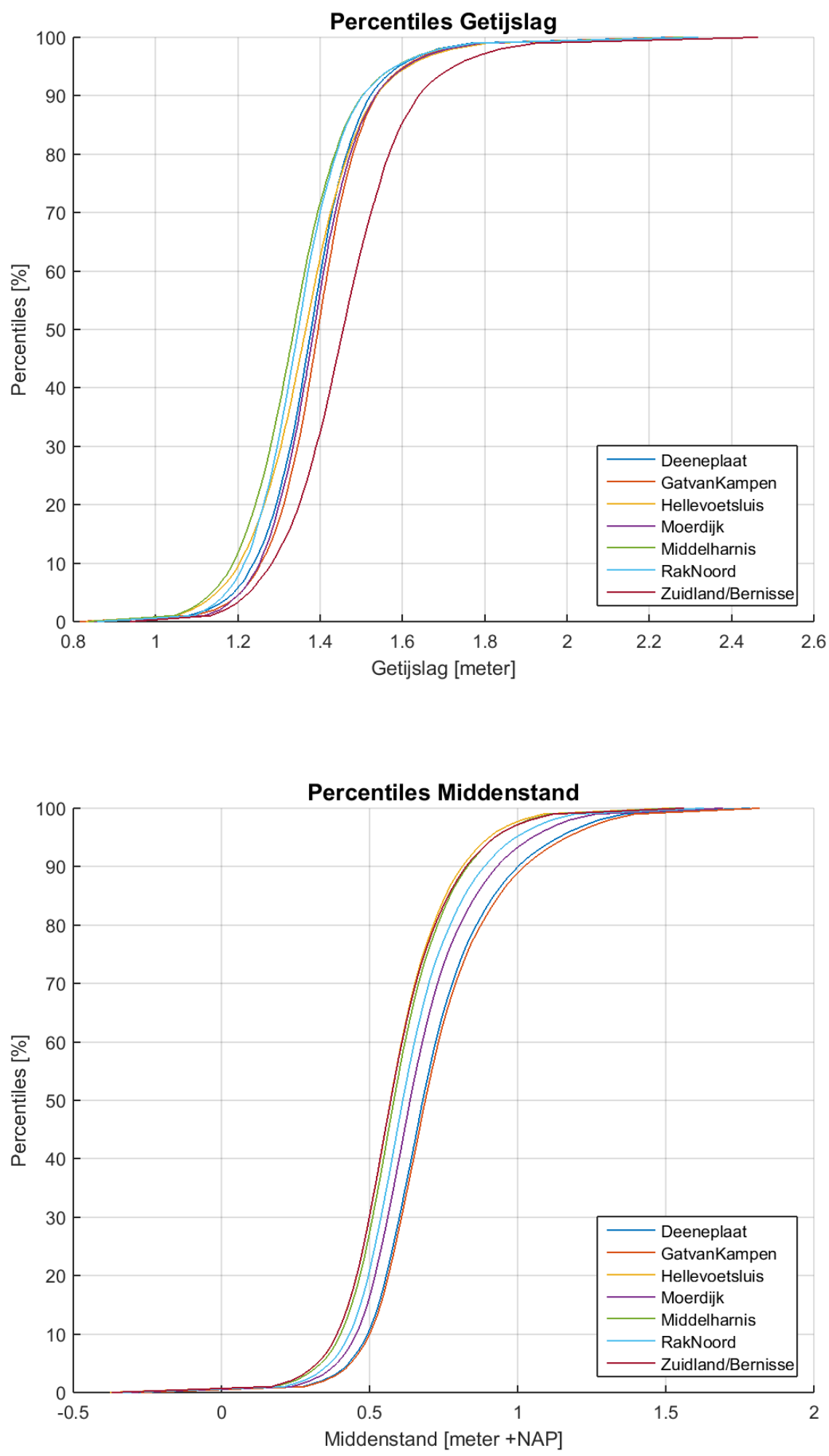

Figuur 59 Percentielen van getijparameters voor de variant Klimaatscenario. 


\section{Bijlage 5 Indeling op basis van hoogteligging}

Hieronder wordt de indeling op basis van de hoogteligging weergegeven die wordt gebruikt voor de ecotopenclassificatie. De indeling is gegeven voor de varianten Huidig beheer, 80-cm getij, Stormvloedkering en Klimaatscenario. De variant Kierbesluit is identiek aan de variant Huidig beheer omdat daar hetzelfde getij is gebruikt.

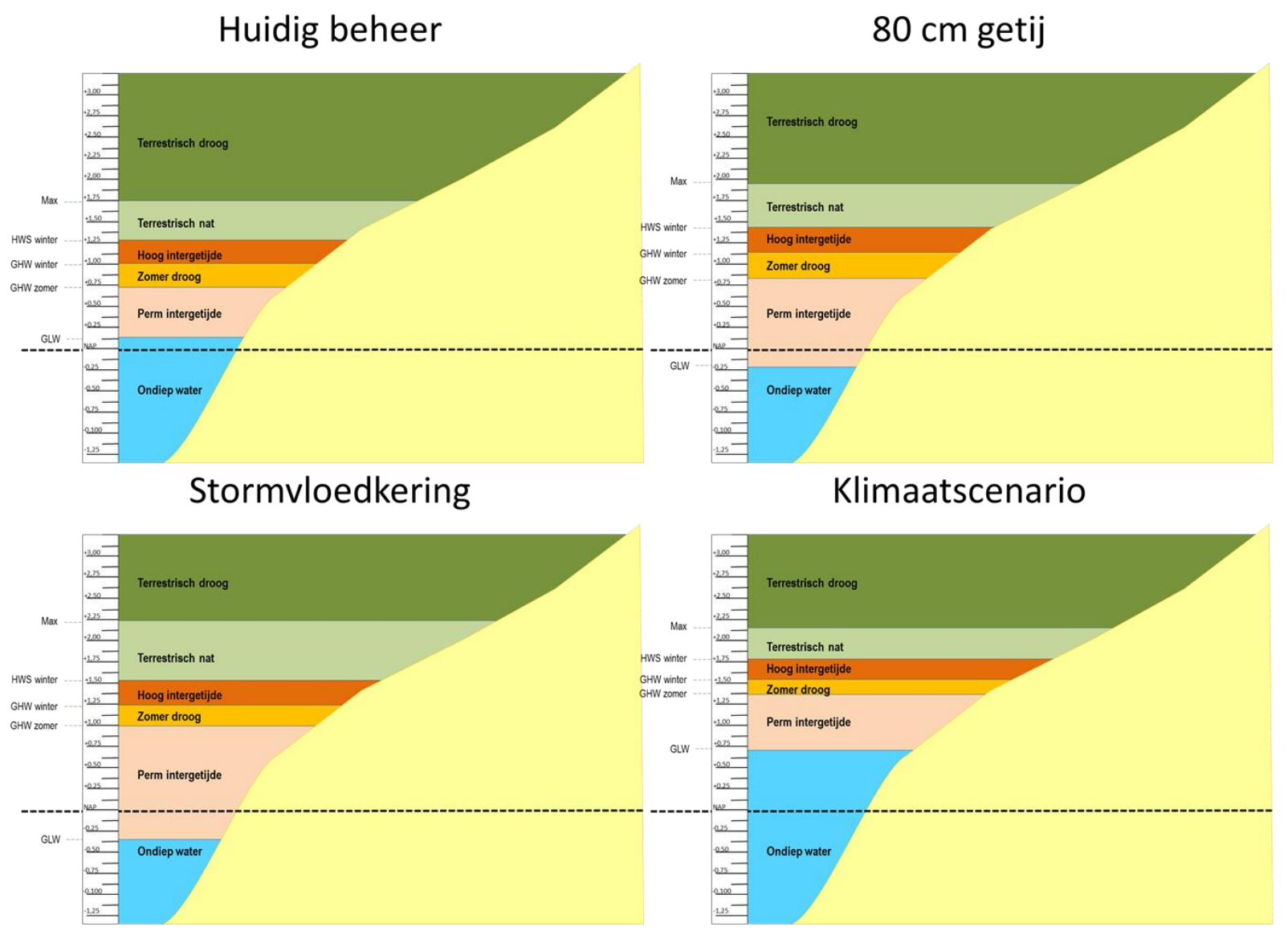

Figuur 60 Schematisch overzicht van de koppeling van de ecotopen aan de getijstatistieken voor de verschillende varianten. Getijstatistieken zijn bepaald voor locatie Deeneplaat. 


\section{Bijlage 6 Waterstanden}

Waterstanden Variant: Huidig beheer Locatie: HLVTSLS hele periode

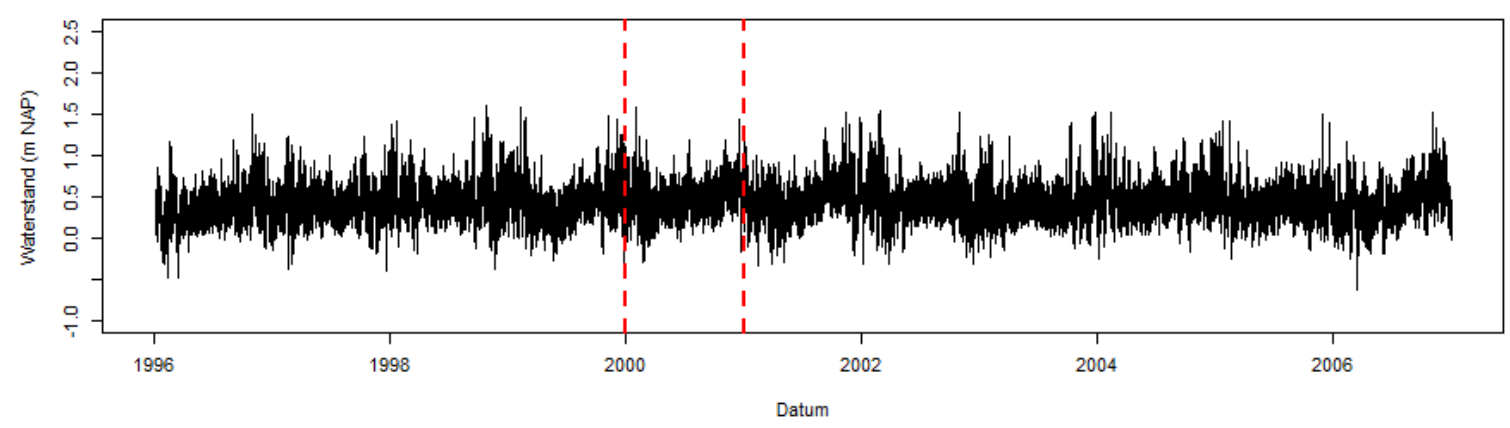

Waterstanden Variant: Huidig beheer Locatie: HLVTSLS in het jaar 2000

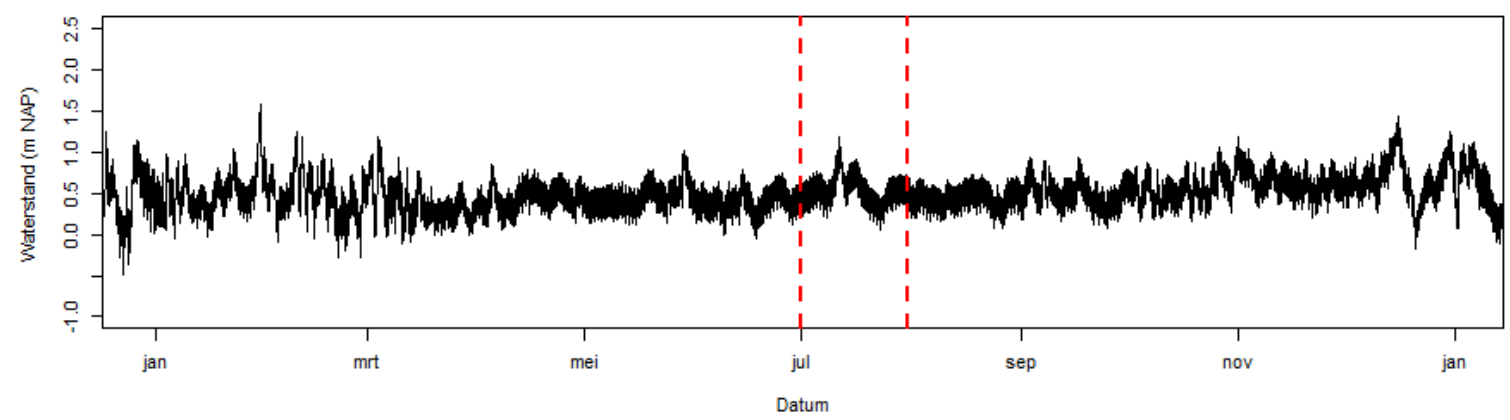

Waterstanden Variant: Huidig beheer Locatie: HLVTSLS voor Jul 2000

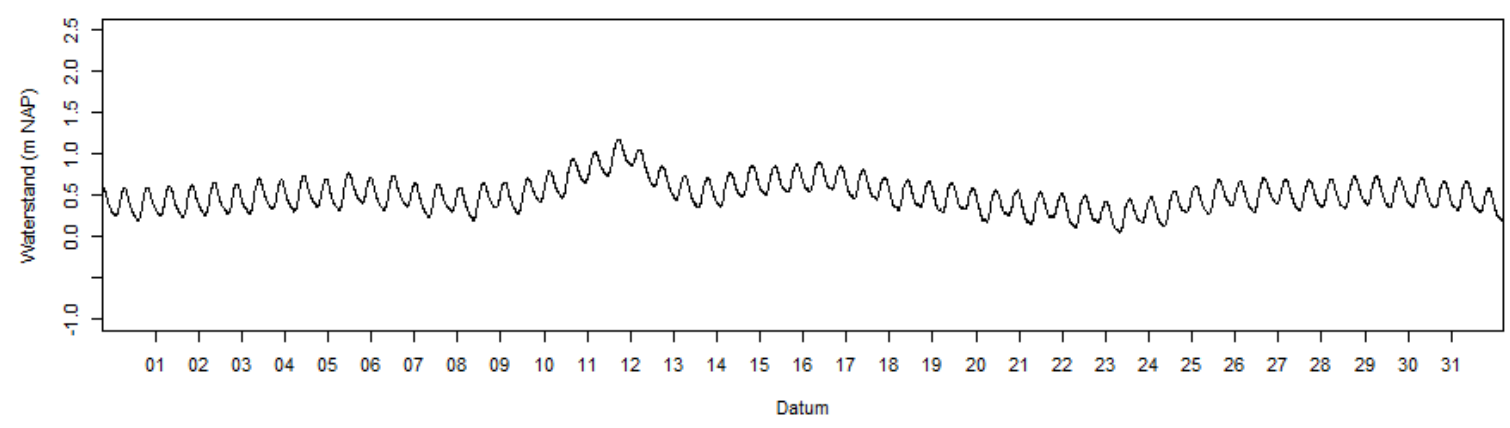

Figuur 61 Berekende waterstanden voor de locatie Hellevoetsluis voor de variant Huidig beheer voor de hele periode (bovenste figuur), het jaar 2000 (middelste figuur) en de maand Juli in 2000 (onderste figuur). 


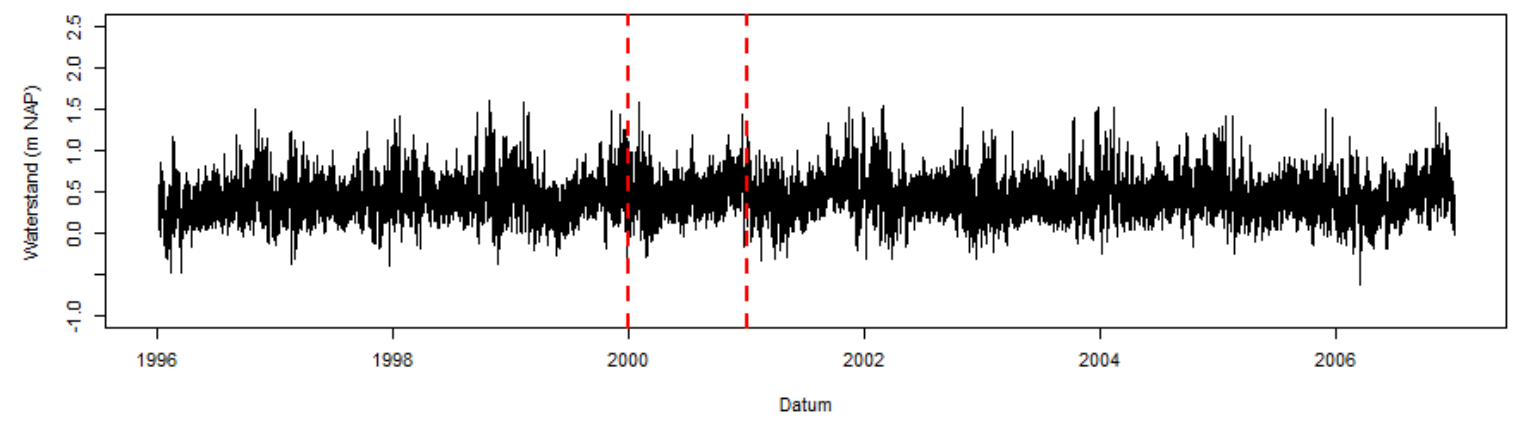

Waterstanden Variant: Kierbesluit Locatie: HLVTSLS in het jaar 2000

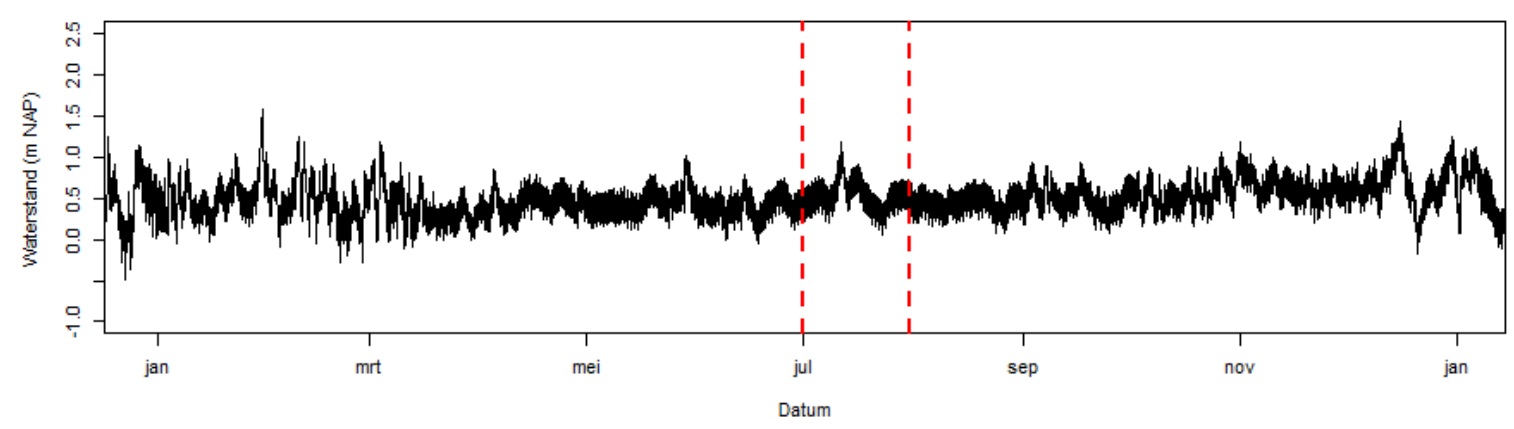

Waterstanden Variant: Kierbesluit Locatie: HLVTSLS voor Jul 2000

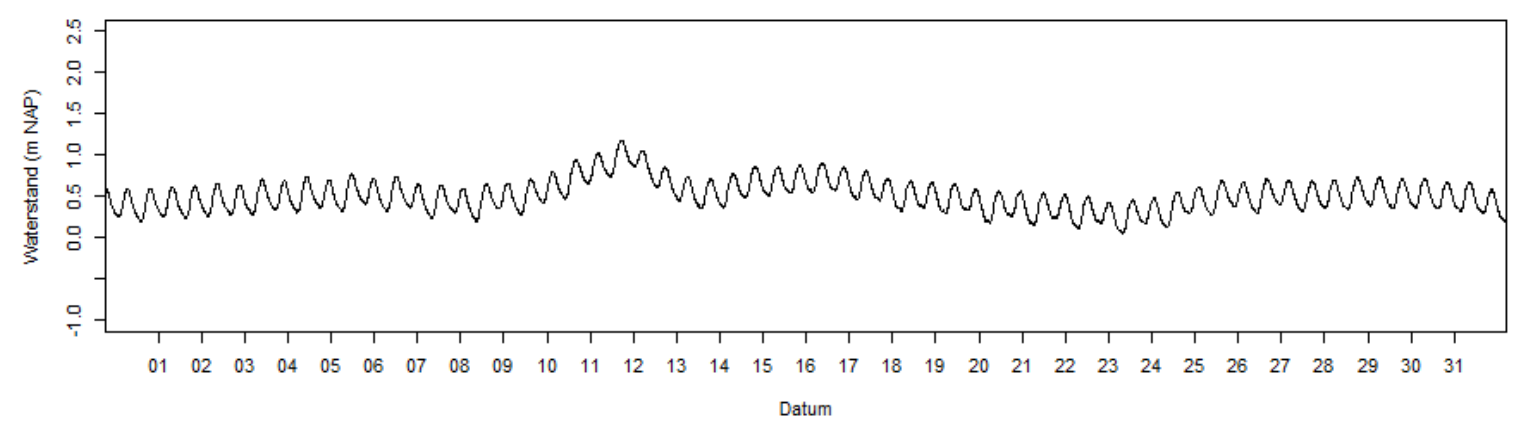

Figuur 62 Berekende waterstanden voor de locatie Hellevoetsluis voor de variant Kierbesluit voor de hele periode (bovenste figuur), het jaar 2000 (middelste figuur) en de maand Juli in 2000 (onderste figuur). Deze figuur is identiek aan die voor variant Huidig beheer (Figuur 61). 


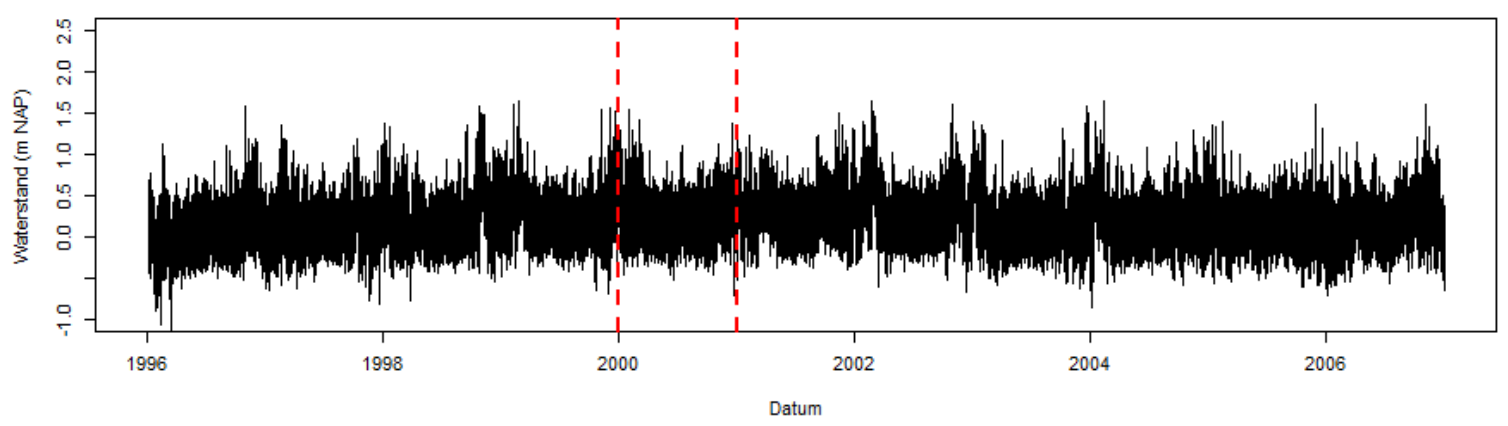

Waterstanden Variant: $80 \mathrm{~cm}$ getij Locatie: HLVTSLS in het jaar 2000

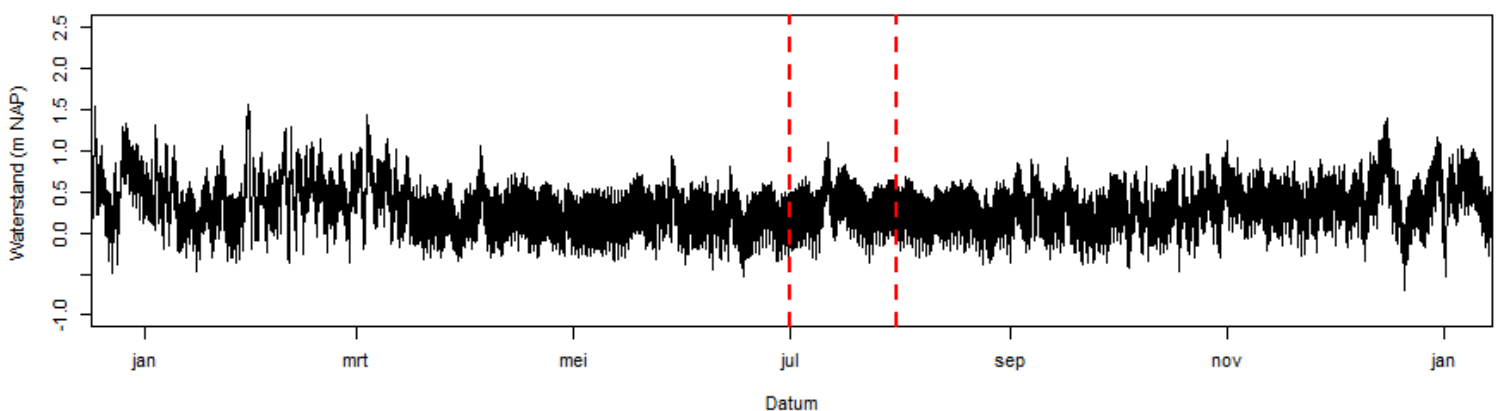

Waterstanden Variant: $80 \mathrm{~cm}$ getij Locatie: HLVTSLS voor Jul 2000

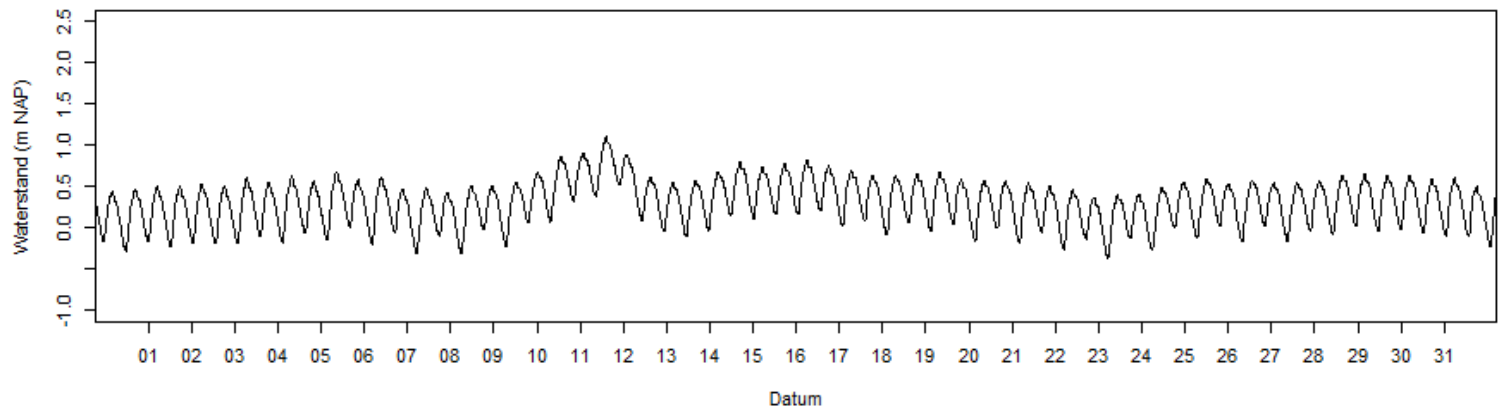

Figuur 63 Berekende waterstanden voor de locatie Hellevoetsluis voor de variant $80 \mathrm{~cm}$ getij voor de hele periode (bovenste figuur), het jaar 2000 (middelste figuur) en de maand Juli in 2000 (onderste figuur). 
Waterstanden Variant: Stormvloedkering Locatie: HLVTSLS hele periode

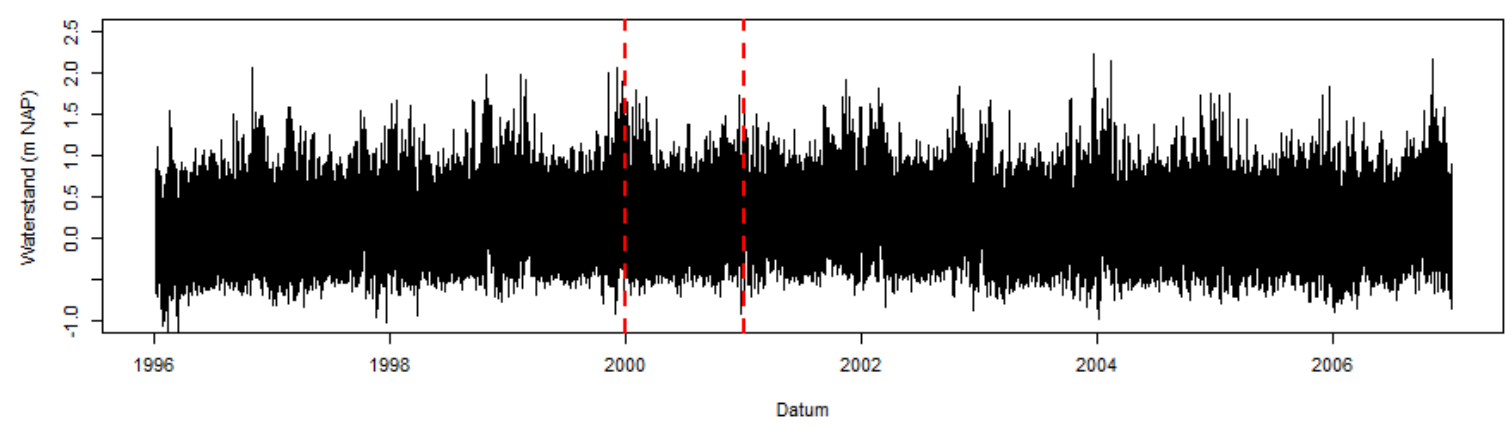

Waterstanden Variant: Stormvloedkering Locatie: HLVTSLS in het jaar 2000

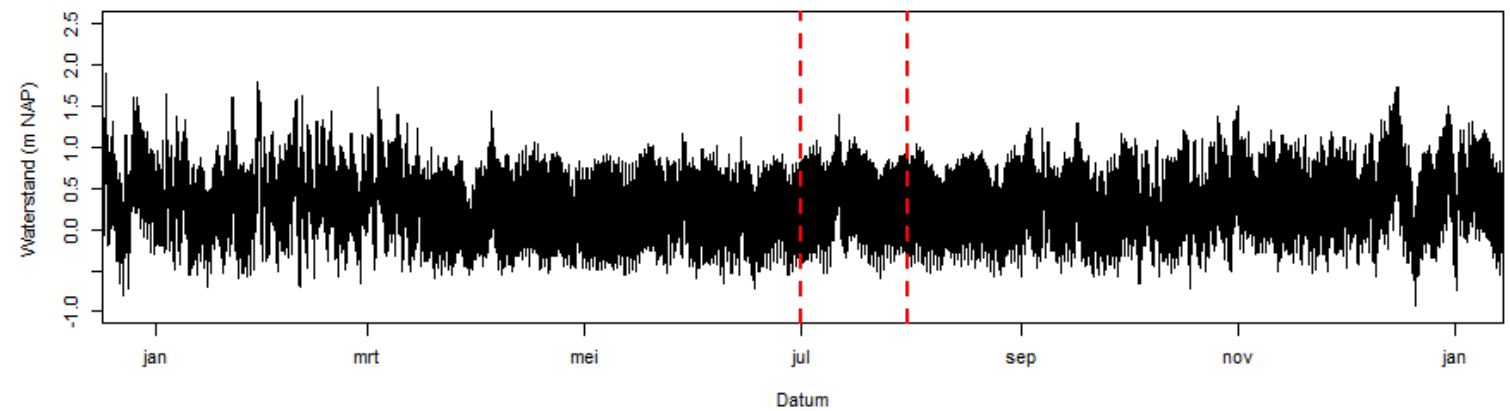

Waterstanden Variant: Stormvloedkering Locatie: HLVTSLS voor Jul 2000

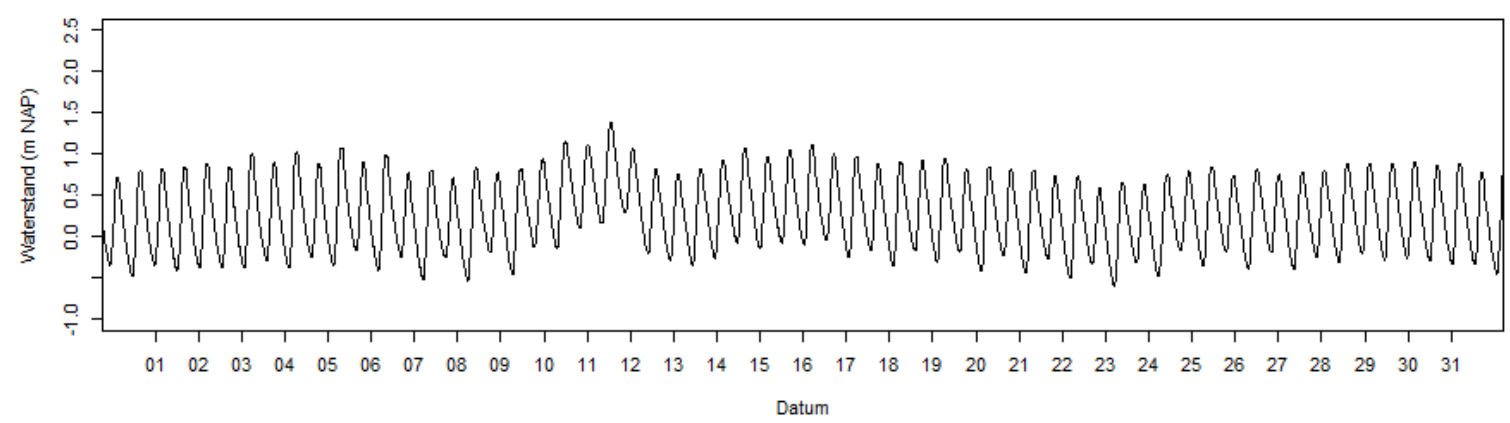

Figuur 64 Berekende waterstanden voor de locatie Hellevoetsluis voor de variant Stormvloedkering voor de hele periode (bovenste figuur), het jaar 2000 (middelste figuur) en de maand Juli in 2000 (onderste figuur). 


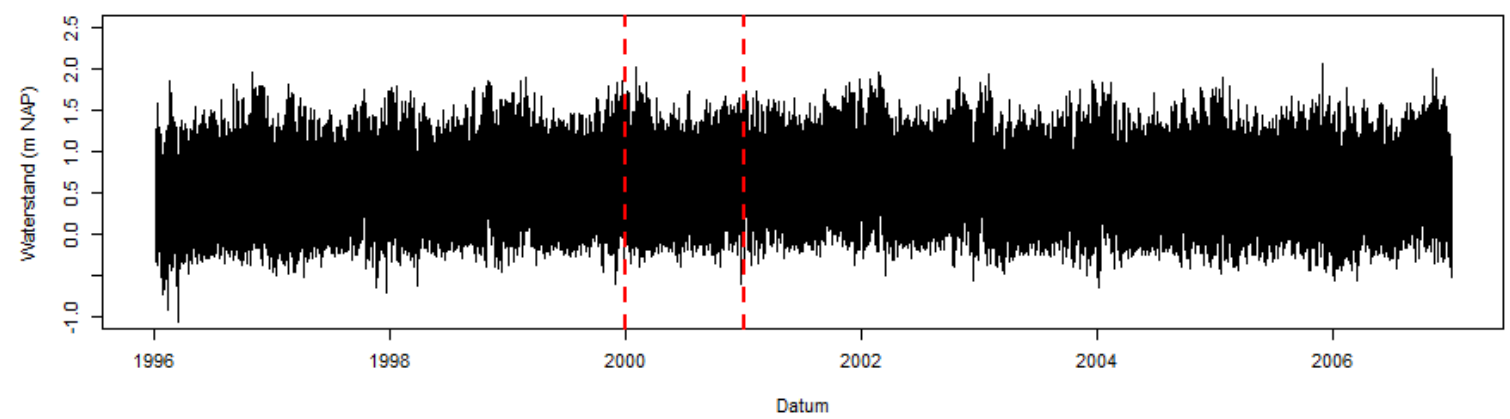

Waterstanden Variant: Klimaatscenario Locatie: HLVTSLS in het jaar 2000

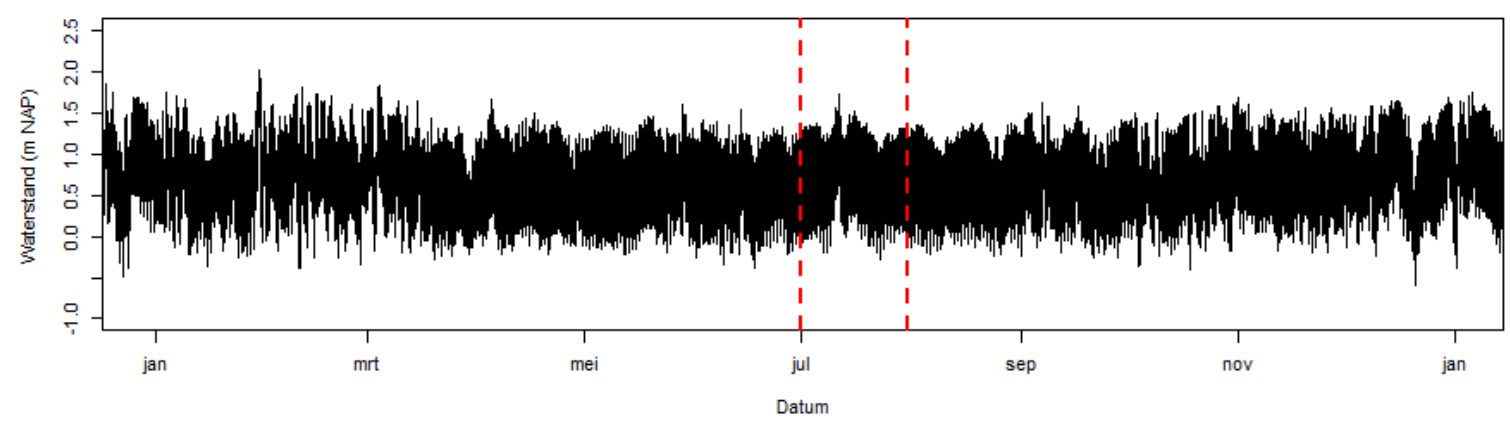

Waterstanden Variant: Klimaatscenario Locatie: HLVTSLS voor Jul 2000

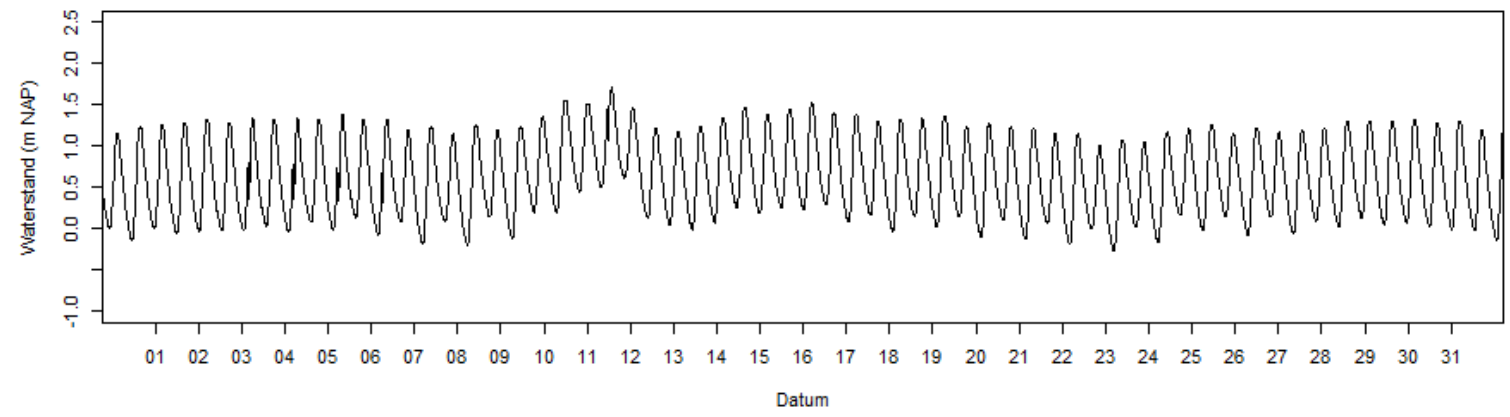

Figuur 65 Berekende waterstanden voor de locatie Hellevoetsluis voor de variant Klimaatscenario voor de hele periode (bovenste figuur), het jaar 2000 (middelste figuur) en de maand Juli in 2000 (onderste figuur). 


\section{Bijlage 7 Ecotopenkaarten Haringvliet west}
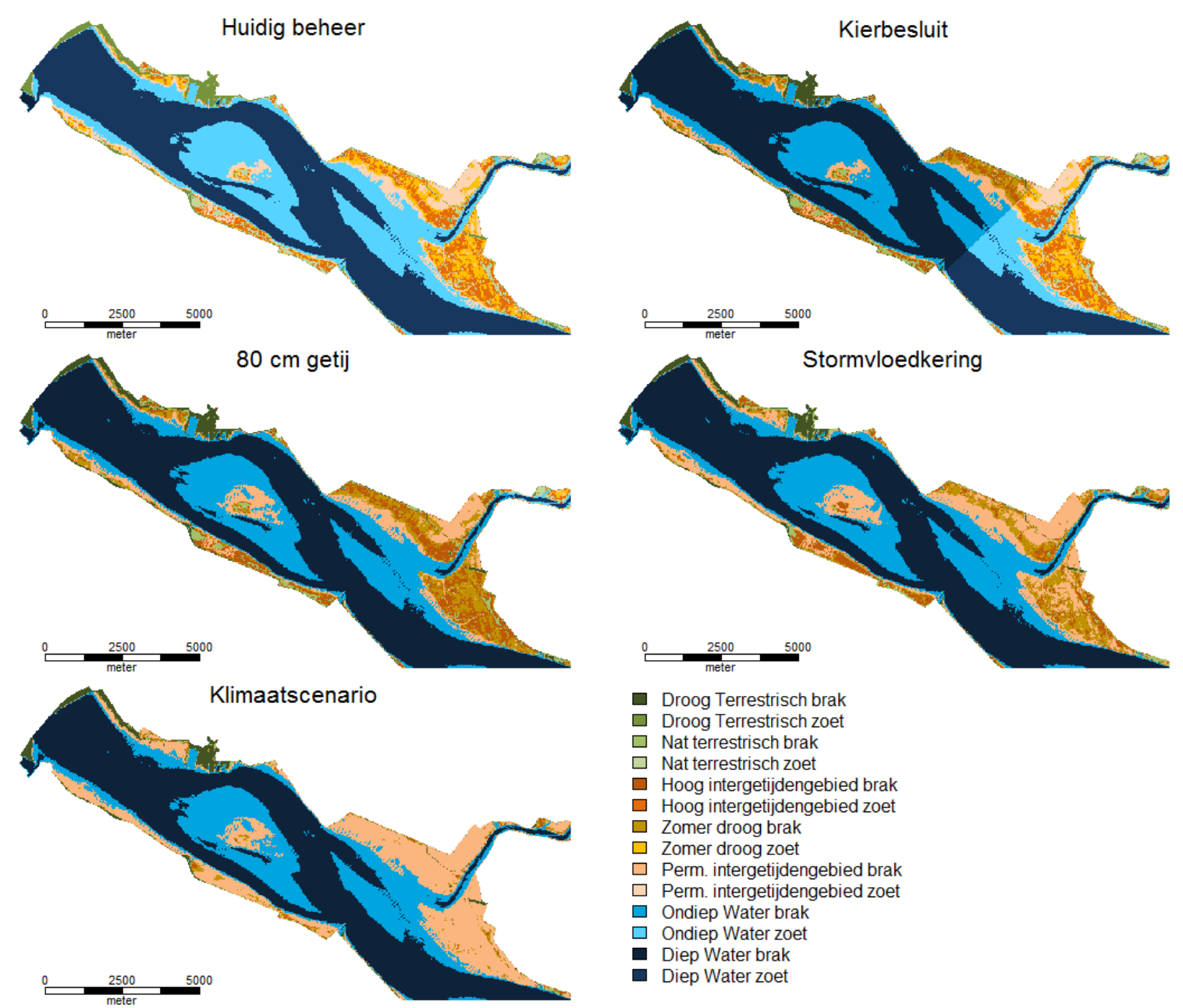
Droog Terrestrisch brak
$\square$ Droog Terrestrisch zoet
$\square$ Nat terrestrisch brak
$\square$ Nat terrestrisch zoet
$\square$ Hoog intergetijdengebied brak
$\square$ Hoog intergetijdengebied zoet
$\square$ Zomer droog brak
$\square$ Zomer droog zoet
$\square$ Perm. intergetijdengebied brak
$\square$ Perm intergetijdengebied zoet
$\square$ Ondiep Water brak
$\square$ Ondiep Water zoet
- Diep Water brak
Diep Water zoet

Figuur 66 Ligging van de ecotopen in het westelijk deel van het Haringvliet voor de varianten Huidig beheer, Kierbesluit, $80 \mathrm{~cm}$ getij, Stormvloedkering en Klimaatscenario. 


\section{Bijlage 8 Ecotopenkaarten Tiengemeten}
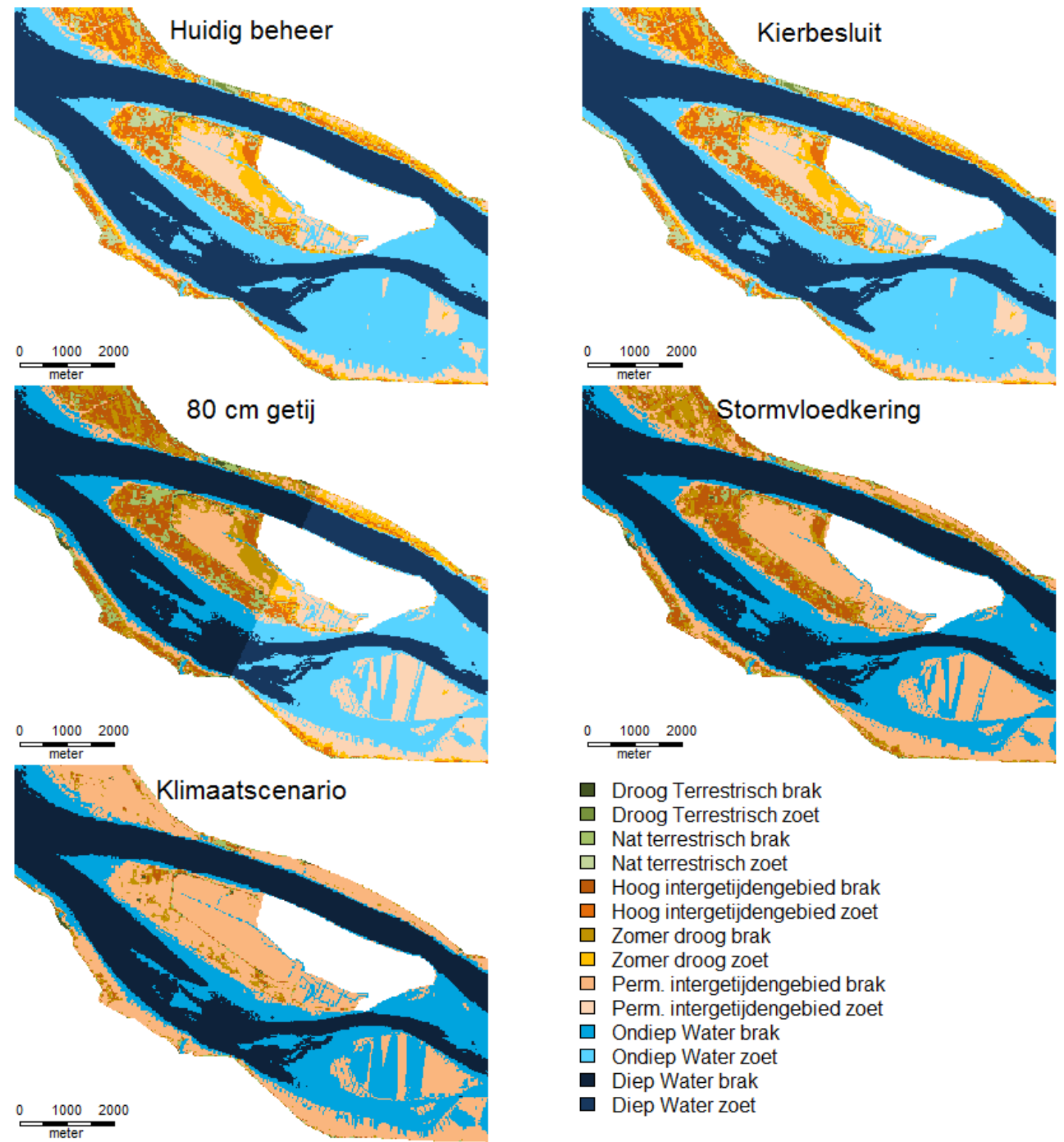

Droog Terrestrisch brak

$\square$ Droog Terrestrisch zoet

$\square$ Nat terrestrisch brak

$\square$ Nat terrestrisch zoet

$\square$ Hoog intergetijdengebied brak

$\square$ Hoog intergetijdengebied zoet

$\square$ Zomer droog brak

$\square$ Zomer droog zoet

$\square$ Perm. intergetijdengebied brak

$\square$ Perm. intergetijdengebied zoet

$\square$ Ondiep Water brak

$\square$ Ondiep Water zoet

- Diep Water brak

Diep Water zoet

Figuur 67 Ligging van de ecotopen rond Tiengemeten voor de varianten Huidig beheer, Kierbesluit, $80 \mathrm{~cm}$ getij, Stormvloedkering en Klimaatscenario. 


\section{Bijlage 9 Ecotopenkaarten Biesbosch}
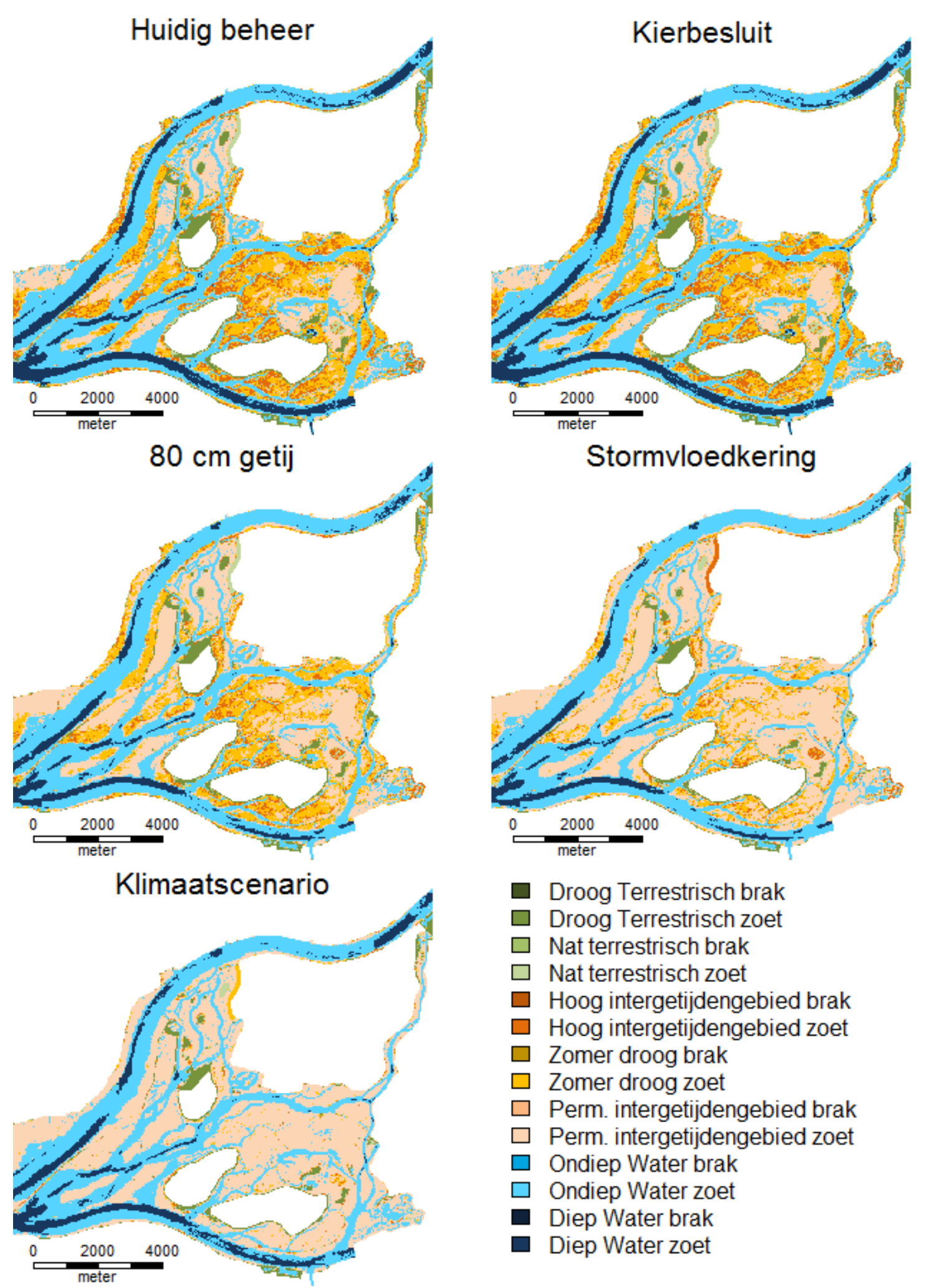

$\square$ Droog Terrestrisch brak

$\square$ Droog Terrestrisch zoet

$\square$ Nat terrestrisch brak

$\square$ Nat terrestrisch zoet

$\square$ Hoog intergetijdengebied brak

$\square$ Hoog intergetijdengebied zoet

$\square$ Zomer droog brak

$\square$ Zomer droog zoet

$\square$ Perm. intergetijdengebied brak

$\square$ Perm. intergetijdengebied zoet

$\square$ Ondiep Water brak

$\square$ Ondiep Water zoet

- Diep Water brak

- Diep Water zoet

Figuur 68 Ligging van de ecotopen in de Biesbosch voor de varianten Huidig beheer, Kierbesluit, $80 \mathrm{~cm}$ getij, Stormvloedkering en Klimaatscenario. 


\section{Bijlage 10 Arealen ecotopen deelgebieden}

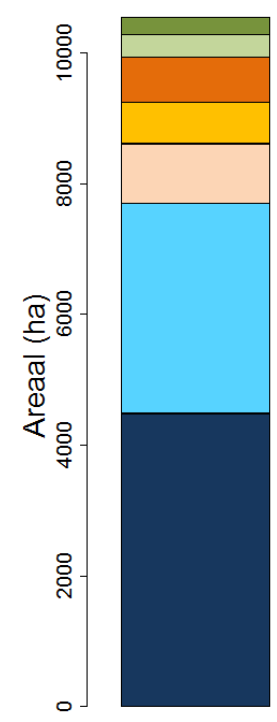

Huidig beheer

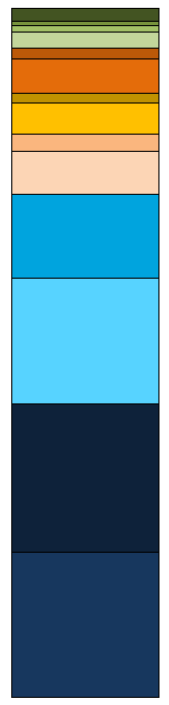

Kierbesluit

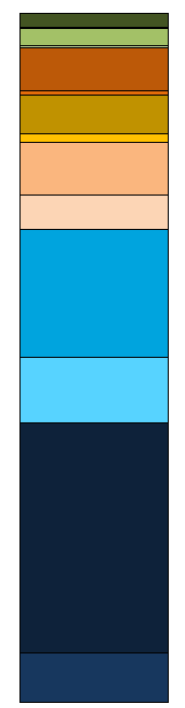

$80 \mathrm{~cm}$ getij Variant
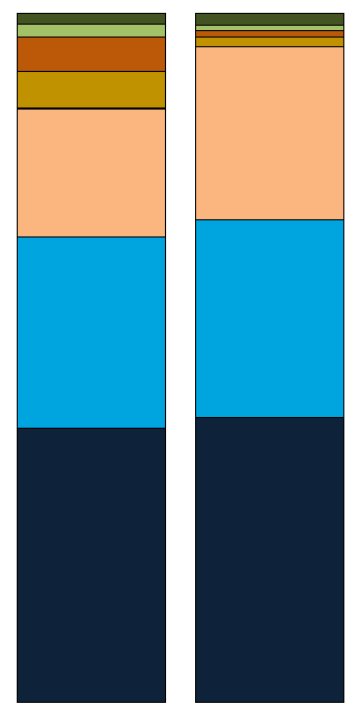

Stormvloedkering Klimaatscenario

\author{
Haringvliet \\ Droog Terrestrisch brak \\ Droog Terrestrisch zoet \\ Nat terrestrisch brak \\ $\square$ Nat terrestrisch zoet \\ $\square$ Hoog intergetijdengebied brak \\ $\square$ Hoog intergetijdengebied zoet \\ Zomer droog brak \\ Zomer droog zoet \\ $\square$ Perm. intergetijdengebied brak \\ $\square$ Perm. intergetijdengebied zoet \\ $\square$ Ondiep Water brak \\ $\square$ Ondiep Water zoet \\ - Diep Water brak \\ - Diep Water zoet
}

Figuur 69 Arealen ecotopen in het Haringvliet voor de varianten Huidig beheer, Kierbesluit, $80 \mathrm{~cm}$ getij, Stormvloedkering en Klimaatscenario.

Tabel 15 Arealen ecotopen (ha) in het Haringvliet.

\begin{tabular}{|c|c|c|c|c|c|}
\hline Ecotoop & $\begin{array}{l}\text { Huidig } \\
\text { beheer }\end{array}$ & Kierbesluit & $\begin{array}{l}80 \mathrm{~cm} \\
\text { getij }\end{array}$ & $\begin{array}{l}\text { Stormvloed- } \\
\text { kering }\end{array}$ & $\begin{array}{l}\text { Klimaat- } \\
\text { scenaric }\end{array}$ \\
\hline Diep Water zoet & 4.470 & 2.229 & 756 & 0 & 0 \\
\hline Ondiep Water zoet & 3.206 & 1.924 & 991 & 0 & 0 \\
\hline Permanent intergetijdengebied zoet & 915 & 655 & 516 & 0 & 0 \\
\hline Zomer droog zoet & 639 & 487 & 129 & 1 & 0 \\
\hline Hoog intergetijdengebied zoet & 686 & 514 & 73 & 2 & 0 \\
\hline Nat terrestrisch zoet & 348 & 237 & 32 & 1 & 0 \\
\hline Droog Terrestrisch zoet & 259 & 67 & 12 & 1 & 0 \\
\hline Diep Water brak & 15 & 2.257 & 3.526 & 4.200 & 4.356 \\
\hline Ondiep Water brak & 2 & 1.284 & 1.966 & 2.918 & 3.027 \\
\hline Permanent intergetijdengebied brak & 0 & 260 & 810 & 1.967 & 2.654 \\
\hline Zomer droog brak & 0 & 152 & 592 & 573 & 143 \\
\hline Hoog intergetijdengebied brak & 0 & 171 & 658 & 523 & 100 \\
\hline Nat terrestrisch brak & 0 & 112 & 258 & 193 & 80 \\
\hline Droog Terrestrisch brak & 1 & 193 & 223 & 164 & 182 \\
\hline Totaal & 10.542 & 10.542 & 10.542 & 10.542 & 10.542 \\
\hline Potentieel intergetijdengebied & 2.240 & 2.240 & 2.778 & 3.065 & 2.897 \\
\hline
\end{tabular}




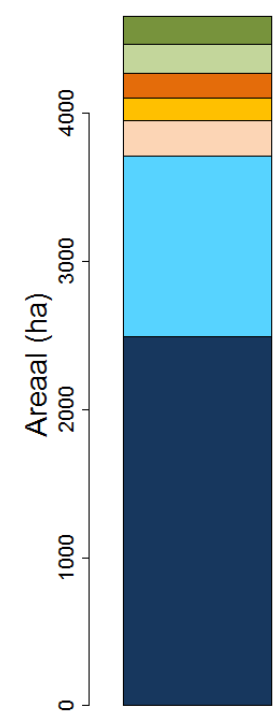

Huidig beheer

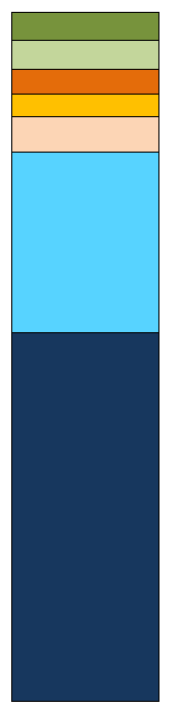

Kierbesluit

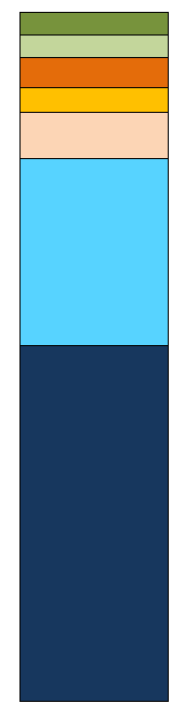

$80 \mathrm{~cm}$ getij Variant

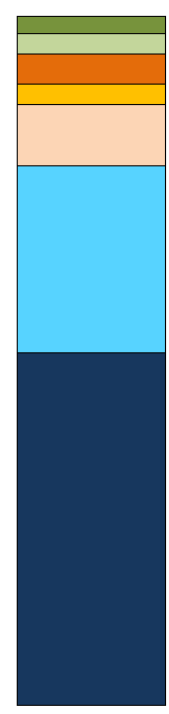

Stormvloedkering

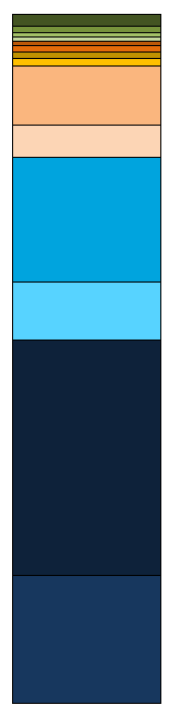

Klimaatscenario
Hollands Diep

Droog Terrestrisch brak

Droog Terrestrisch zoet

$\square$ Nat terrestrisch brak

$\square$ Nat terrestrisch zoet

$\square$ Hoog intergetijdengebied brak

$\square$ Hoog intergetijdengebied zoet

Zomer droog brak

Zomer droog zoet

Perm. intergetijdengebied brak

$\square$ Perm. intergetijdengebied zoet

Ondiep Water brak

$\square$ Ondiep Water zoet

- Diep Water brak

- Diep Water zoet

Figuur 70 Arealen ecotopen in het Hollands Diep voor de varianten Huidig beheer, Kierbesluit, $80 \mathrm{~cm}$ getij, Stormvloedkering en Klimaatscenario.

Tabel 16 Arealen ecotopen (ha) in het Hollands Diep.

\begin{tabular}{|c|c|c|c|c|c|}
\hline Ecotoop & $\begin{array}{l}\text { Huidig } \\
\text { beheer }\end{array}$ & Kierbesluit & $\begin{array}{c}80 \mathrm{~cm} \\
\text { getij }\end{array}$ & $\begin{array}{l}\text { Stormvloed- } \\
\text { kering }\end{array}$ & $\begin{array}{l}\text { Klimaat- } \\
\text { scenario }\end{array}$ \\
\hline Diep Water zoet & 2.493 & 2.493 & 2.408 & 2.381 & 866 \\
\hline Ondiep Water zoet & 1.218 & 1.218 & 1.261 & 1.269 & 396 \\
\hline Permanent intergetijdengebied zoet & 243 & 243 & 311 & 412 & 214 \\
\hline Zomer droog zoet & 152 & 152 & 166 & 134 & 51 \\
\hline Hoog intergetijdengebied zoet & 166 & 166 & 203 & 206 & 46 \\
\hline Nat terrestrisch zoet & 197 & 197 & 153 & 134 & 28 \\
\hline Droog Terrestrisch zoet & 187 & 187 & 155 & 120 & 44 \\
\hline Diep Water brak & 0 & 0 & 0 & 0 & 1.590 \\
\hline Ondiep Water brak & 0 & 0 & 0 & 0 & 840 \\
\hline Permanent intergetijdengebied brak & 0 & 0 & 0 & 0 & 404 \\
\hline Zomer droog brak & 0 & 0 & 0 & 0 & 40 \\
\hline Hoog intergetijdengebied brak & 0 & 0 & 0 & 0 & 29 \\
\hline Nat terrestrisch brak & 0 & 0 & 0 & 0 & 29 \\
\hline Droog Terrestrisch brak & 0 & 0 & 0 & 0 & 80 \\
\hline Totaal & 4.656 & 4.656 & 4.656 & 4.656 & .4656 \\
\hline Potentieel intergetijdengebied & 561 & 561 & 679 & 753 & 783 \\
\hline
\end{tabular}




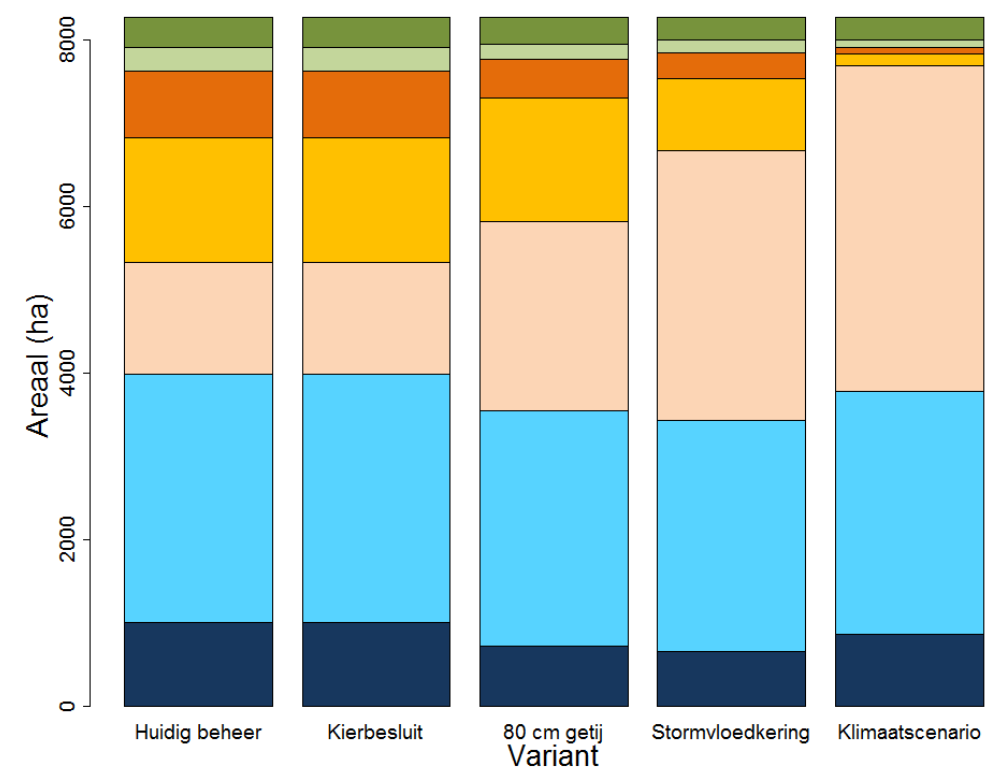

\section{Biesbosch}

Droog Terrestrisch brak

$\square$ Droog Terrestrisch zoet

$\square$ Nat terrestrisch brak

$\square \quad$ Nat terrestrisch zoet

$\square$ Hoog intergetijdengebied brak

$\square$ Hoog intergetijdengebied zoet

$\square$ Zomer droog brak

$\square$ Zomer droog zoet

$\square$ Perm. intergetijdengebied brak

$\square$ Perm. intergetijdengebied zoet

$\square$ Ondiep Water brak

$\square$ Ondiep Water zoet

- Diep Water brak

- Diep Water zoet

Figuur 71 Arealen ecotopen in Biesbosch voor de varianten Huidig beheer, Kierbesluit, $80 \mathrm{~cm}$ getij, Stormvloedkering en Klimaatscenario.

\begin{tabular}{|c|c|c|c|c|c|}
\hline Ecotoop & $\begin{array}{l}\text { Huidig } \\
\text { beheer }\end{array}$ & Kierbesluit & $\begin{array}{c}80 \mathrm{~cm} \\
\text { getij }\end{array}$ & $\begin{array}{l}\text { Stormvloed- } \\
\text { kering }\end{array}$ & $\begin{array}{l}\text { Klimaat- } \\
\text { scenario }\end{array}$ \\
\hline Diep Water zoet & 1.005 & 1.005 & 724 & 659 & 870 \\
\hline Ondiep Water zoet & 2.987 & 2.987 & 2.834 & 2.778 & 2.917 \\
\hline Permanent intergetijdengebied zoet & .1339 & 1.339 & 2.262 & 3.240 & 3.911 \\
\hline Zomer droog zoet & .1501 & 1.501 & 1.490 & 860 & 145 \\
\hline Hoog intergetijdengebied zoet & 795 & 795 & 466 & 316 & 75 \\
\hline Nat terrestrisch zoet & 282 & 282 & 176 & 157 & 85 \\
\hline Droog Terrestrisch zoet & 368 & 368 & 327 & 268 & 276 \\
\hline Diep Water brak & 0 & 0 & 0 & 0 & 0 \\
\hline Ondiep Water brak & 0 & 0 & 0 & 0 & 0 \\
\hline Permanent intergetijdengebied brak & 0 & 0 & 0 & 0 & 0 \\
\hline Zomer droog brak & 0 & 0 & 0 & 0 & 0 \\
\hline Hoog intergetijdengebied brak & 0 & 0 & 0 & 0 & 0 \\
\hline Nat terrestrisch brak & 0 & 0 & 0 & 0 & 0 \\
\hline Droog Terrestrisch brak & 0 & 0 & 0 & 0 & 0 \\
\hline Totaal & 8.278 & 8.278 & 8.278 & 8.278 & 8.278 \\
\hline Potentieel intergetijdengebied & 3.635 & 3.635 & 4.217 & 4.416 & 4.130 \\
\hline
\end{tabular}




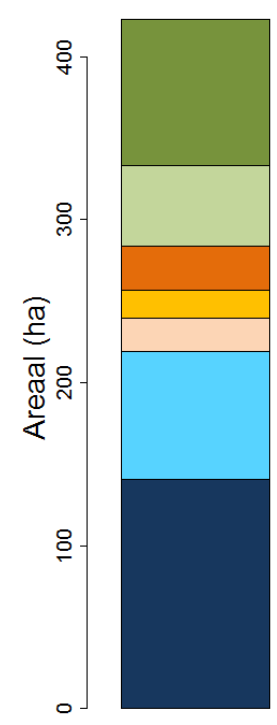

Huidig beheer

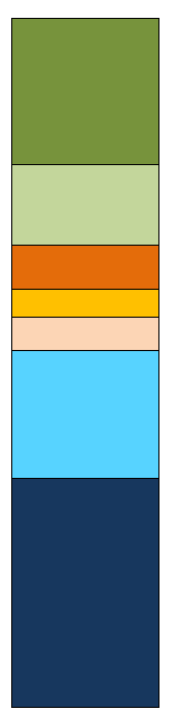

Kierbesluit

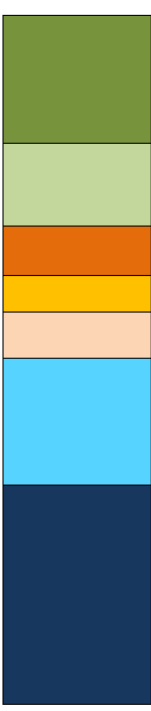

$80 \mathrm{~cm}$ geti $80 \mathrm{~cm}$ geti
Variant

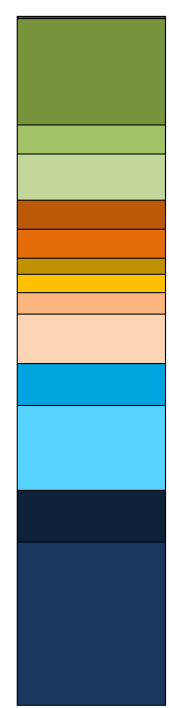

Stormvloedkering Klimaatscenario
Spui

- Droog Terrestrisch brak

$\square$ Droog Terrestrisch zoet

$\square$ Nat terrestrisch brak

$\square \quad$ Nat terrestrisch zoet

$\square$ Hoog intergetijdengebied brak

$\square$ Hoog intergetijdengebied zoet

$\square$ Zomer droog brak

$\square$ Zomer droog zoet

$\square$ Perm. intergetijdengebied brak

$\square$ Perm. intergetijdengebied zoet

$\square$ Ondiep Water brak

$\square$ Ondiep Water zoet

- Diep Water brak

- Diep Water zoet

Figuur 72 Arealen ecotopen in het Spui voor de varianten Huidig beheer, Kierbesluit, $80 \mathrm{~cm}$ getij, Stormvloedkering en Klimaatscenario.

Tabel 18 Arealen ecotopen (ha) in het Spui.

\begin{tabular}{|c|c|c|c|c|c|}
\hline Ecotoop & $\begin{array}{l}\text { Huidig } \\
\text { beheer }\end{array}$ & Kierbesluit & $\begin{array}{c}80 \mathrm{~cm} \\
\text { getij }\end{array}$ & $\begin{array}{l}\text { Stormvloed- } \\
\text { kering }\end{array}$ & $\begin{array}{l}\text { Klimaat- } \\
\text { scenario }\end{array}$ \\
\hline Diep Water zoet & 141 & 141 & 135 & 101 & 86 \\
\hline Ondiep Water zoet & 78 & 78 & 78 & 52 & 48 \\
\hline Permanent intergetijdengebied zoet & 20 & 20 & 28 & 30 & 35 \\
\hline Zomer droog zoet & 17 & 17 & 23 & 11 & 5 \\
\hline Hoog intergetijdengebied zoet & 27 & 27 & 30 & 18 & 10 \\
\hline Nat terrestrisch zoet & 49 & 49 & 51 & 29 & 10 \\
\hline Droog Terrestrisch zoet & 90 & 90 & 78 & 65 & 68 \\
\hline Diep Water brak & 0 & 0 & 0 & 32 & 53 \\
\hline Ondiep Water brak & 0 & 0 & 0 & 26 & 31 \\
\hline Permanent intergetijdengebied brak & 0 & 0 & 0 & 13 & 43 \\
\hline Zomer droog brak & 0 & 0 & 0 & 10 & 11 \\
\hline Hoog intergetijdengebied brak & 0 & 0 & 0 & 18 & 12 \\
\hline Nat terrestrisch brak & 0 & 0 & 0 & 18 & 9 \\
\hline Droog Terrestrisch brak & 0 & 0 & 0 & 1 & 2 \\
\hline Totaal & 423 & 423 & 423 & 423 & 423 \\
\hline Potentieel intergetijdengebied & 64 & 64 & 81 & 100 & 116 \\
\hline
\end{tabular}




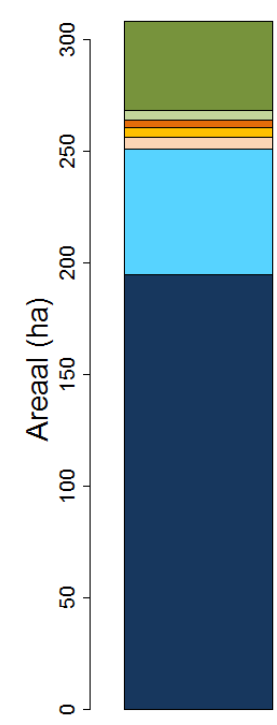

Huidig beheer

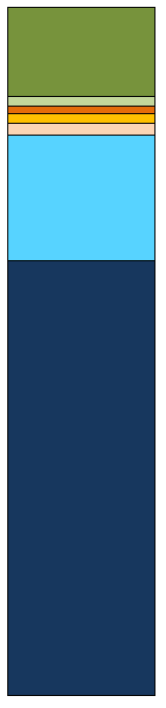

Kierbesluit

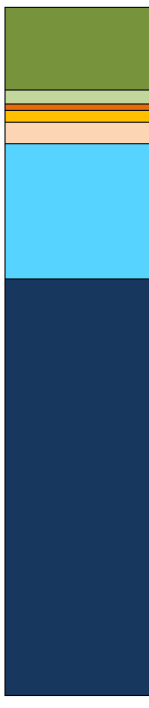

$80 \mathrm{~cm}$ getij

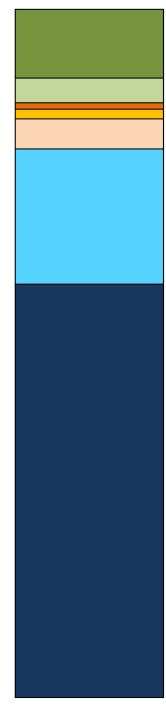

Stormvloedkering

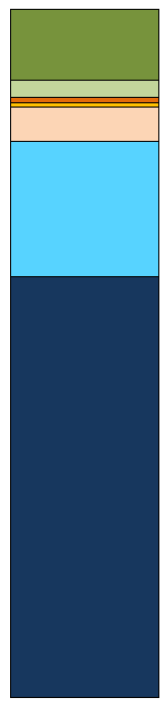

Klimaatscenario

\section{Dordtsche Kil}

Droog Terrestrisch brak

$\square$ Droog Terrestrisch zoet

$\square$ Nat terrestrisch brak

$\square \quad$ Nat terrestrisch zoet

- Hoog intergetijdengebied brak

$\square$ Hoog intergetijdengebied zoet

$\square$ Zomer droog brak

$\square$ Zomer droog zoet

$\square$ Perm. intergetijdengebied brak

$\square$ Perm. intergetijdengebied zoet

$\square$ Ondiep Water brak

$\square$ Ondiep Water zoet

- Diep Water brak

- Diep Water zoet

Figuur 73 Arealen ecotopen in de Dordtsche Kil voor de varianten Huidig beheer, Kierbesluit, $80 \mathrm{~cm}$ getij, Stormvloedkering en Klimaatscenario.

Tabel 19 Arealen ecotopen (ha) in de Dordtsche Kil.

\begin{tabular}{|c|c|c|c|c|c|}
\hline Ecotoop & $\begin{array}{l}\text { Huidig } \\
\text { beheer }\end{array}$ & Kierbesluit & $\begin{array}{c}80 \mathrm{~cm} \\
\text { getij }\end{array}$ & $\begin{array}{l}\text { Stormvloed- } \\
\text { kering }\end{array}$ & $\begin{array}{l}\text { Klimaat- } \\
\text { scenaric }\end{array}$ \\
\hline Diep Water zoet & 194 & 194 & 187 & 185 & 189 \\
\hline Ondiep Water zoet & 57 & 57 & 60 & 61 & 61 \\
\hline Permanent intergetijdengebied zoet & 5 & 5 & 10 & 13 & 15 \\
\hline Zomer droog zoet & 4 & 4 & 5 & 4 & 2 \\
\hline Hoog intergetijdengebied zoet & 4 & 4 & 3 & 3 & 3 \\
\hline Nat terrestrisch zoet & 4 & 4 & 6 & 11 & 8 \\
\hline Droog Terrestrisch zoet & 40 & 40 & 37 & 31 & 32 \\
\hline Diep Water brak & 0 & 0 & 0 & 0 & 0 \\
\hline Ondiep Water brak & 0 & 0 & 0 & 0 & 0 \\
\hline Permanent intergetijdengebied brak & 0 & 0 & 0 & 0 & 0 \\
\hline Zomer droog brak & 0 & 0 & 0 & 0 & 0 \\
\hline Hoog intergetijdengebied brak & 0 & 0 & 0 & 0 & 0 \\
\hline Nat terrestrisch brak & 0 & 0 & 0 & 0 & 0 \\
\hline Droog Terrestrisch brak & 0 & 0 & 0 & 0 & 0 \\
\hline Totaal & 308 & 308 & 308 & 308 & 308 \\
\hline Potentieel intergetijdengebied & 13 & 13 & 18 & 20 & 19 \\
\hline
\end{tabular}




\section{Bijlage 11 Verschilkaarten Ecotopen}
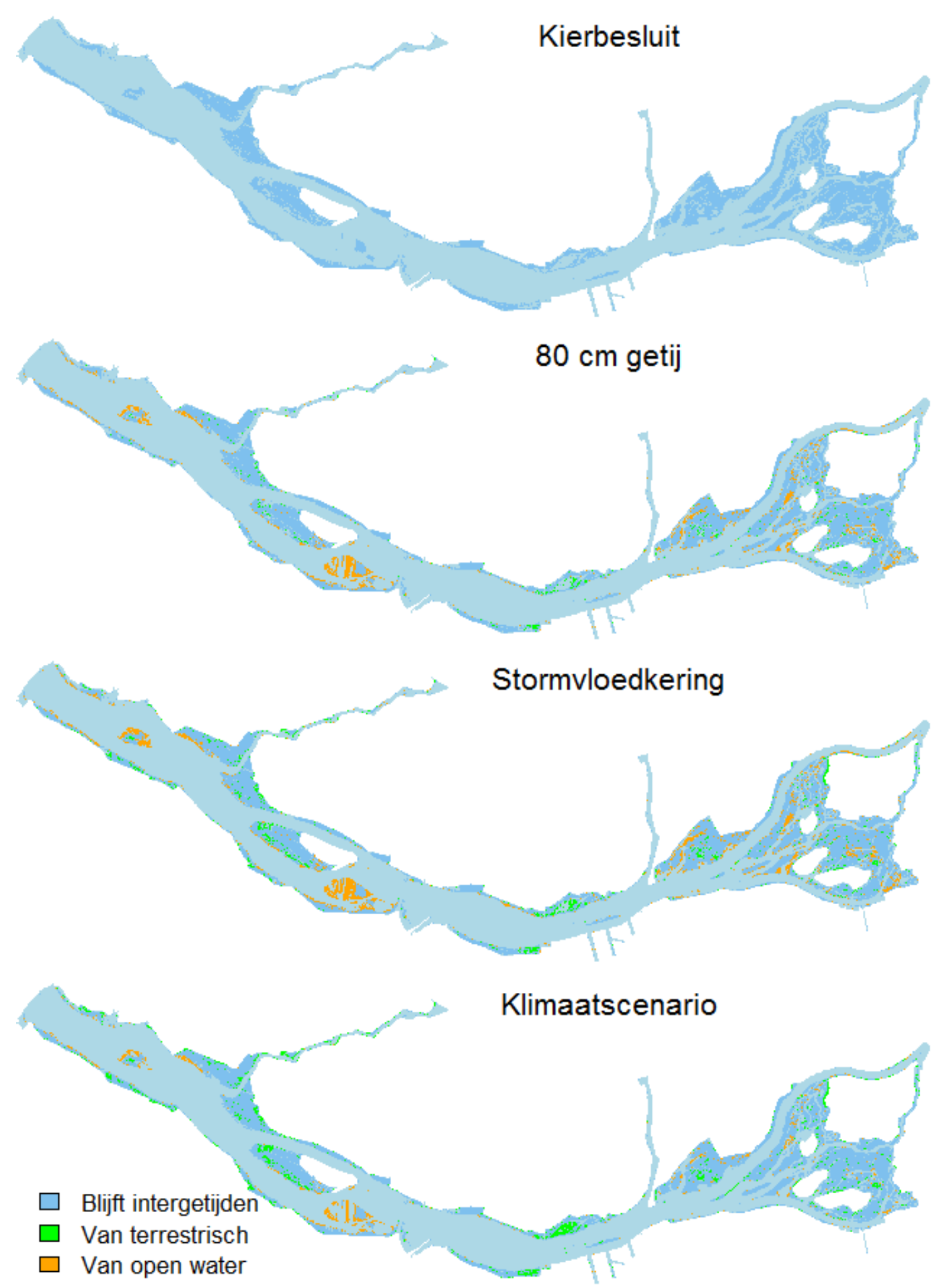

Figuur 74 Verschilkaarten van intergetijdengebieden (variant - Huidig beheer). In donkerder blauw is het gebied aangegeven wat intergetijdengebied blijft. De groene gebieden zijn terrestrische ecotopen in de variant Huidig beheer en worden intergetijdengebied in de betreffende variant. De oranje gebieden zijn open water ecotopen in de variant Huidig beheer en worden intergetijdengebied in de betreffende variant. De groene en oranje gebieden in deze figuur komen overeen met de oranje gebieden van Figuur 47. 


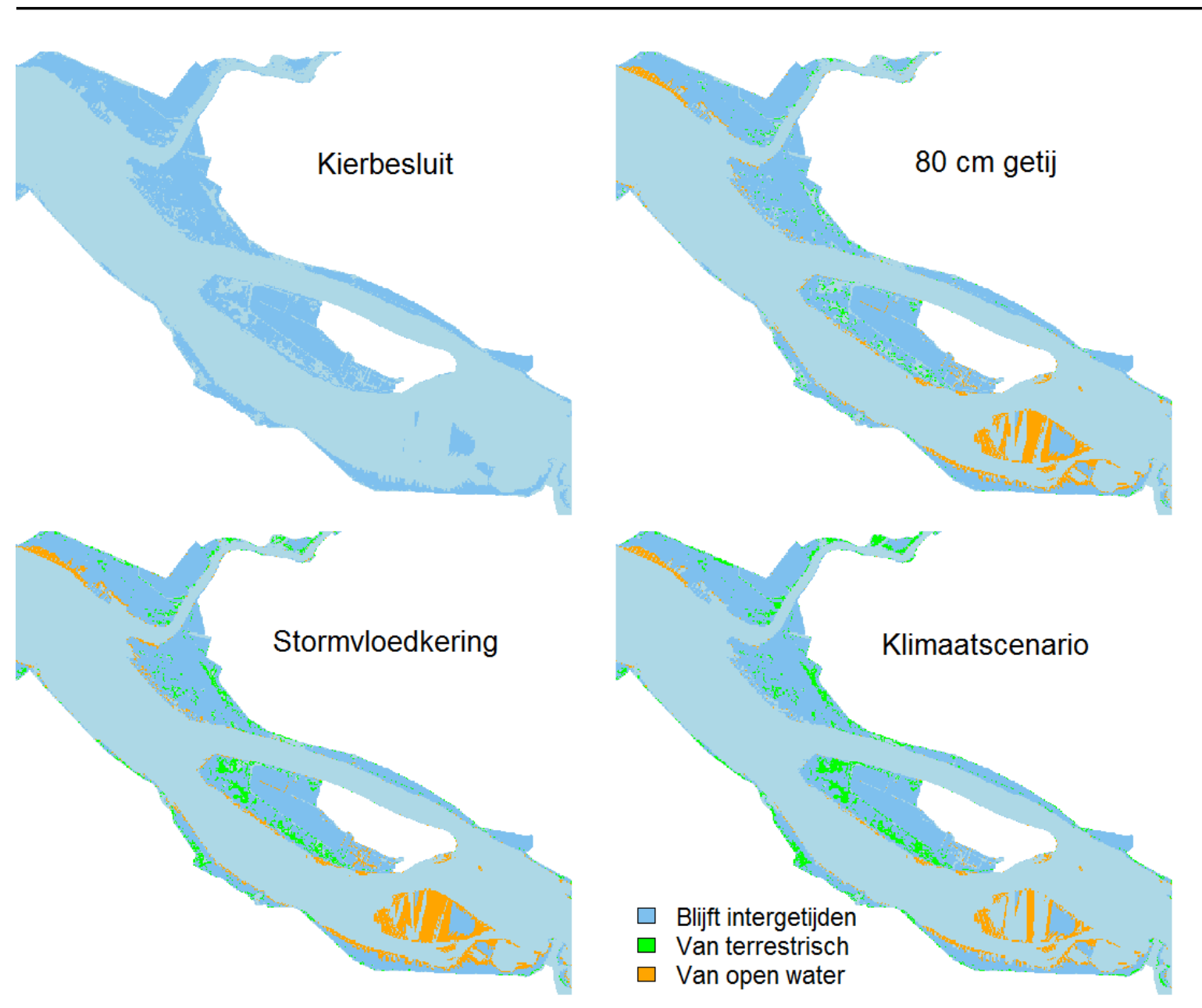

Figuur 75 Uitvergroting van Figuur 74 voor het oostelijk deel van het Haringvliet. Verschilkaarten van intergetijdengebieden (variant - Huidig beheer). In donkerder blauw is het gebied aangegeven wat intergetijdengebied blijft. De groene gebieden zijn terrestrische ecotopen in de variant Huidig beheer en worden intergetijdengebied in de betreffende variant. De oranje gebieden zijn open water ecotopen in de variant Huidig beheer en worden intergetijdengebied in de betreffende variant. De groene en oranje gebieden in deze figuur komen overeen met de oranje gebieden van Figuur 47. 

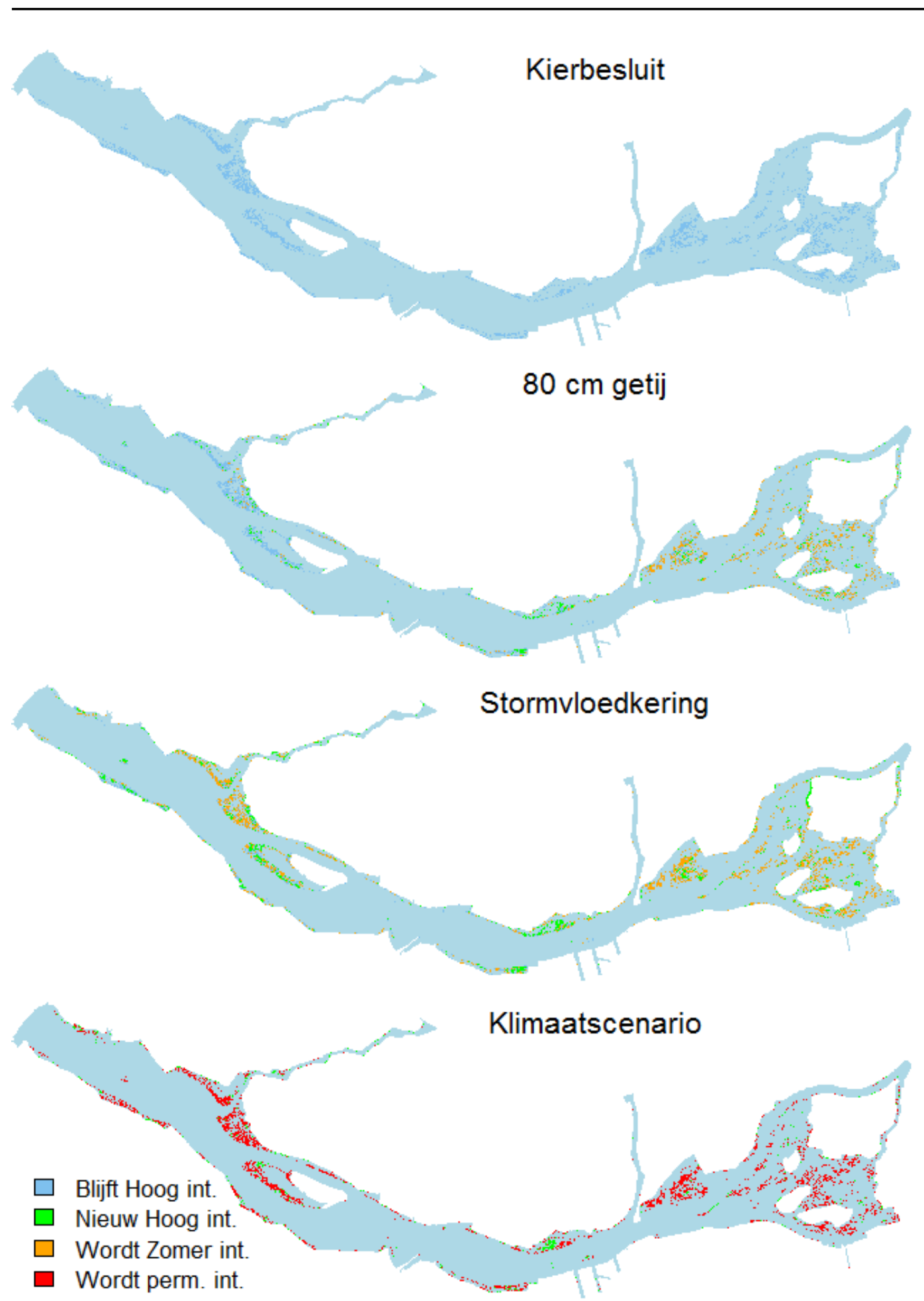

Figuur 76 Verschilkaarten van het ecotoop Hoog intergetijdengebied (variant - Huidig beheer). In donkerder blauw is het gebied aangegeven wat Hoog intergetijdengebied blijft. De groene gebieden zijn de nieuwe gebieden waar Hoog intergetijdengebied ontstaat (was terrestrisch in de variant Huidig beheer). De oranje gebieden zijn de gebieden waar het ecotoop Hoog intergetijdengebied plaatsmaakt voor Zomer intergetijdengebied. De rode gebieden zijn de gebieden waar het ecotoop Hoog intergetijdengebied plaatsmaakt voor permanent intergetijdengebied. 


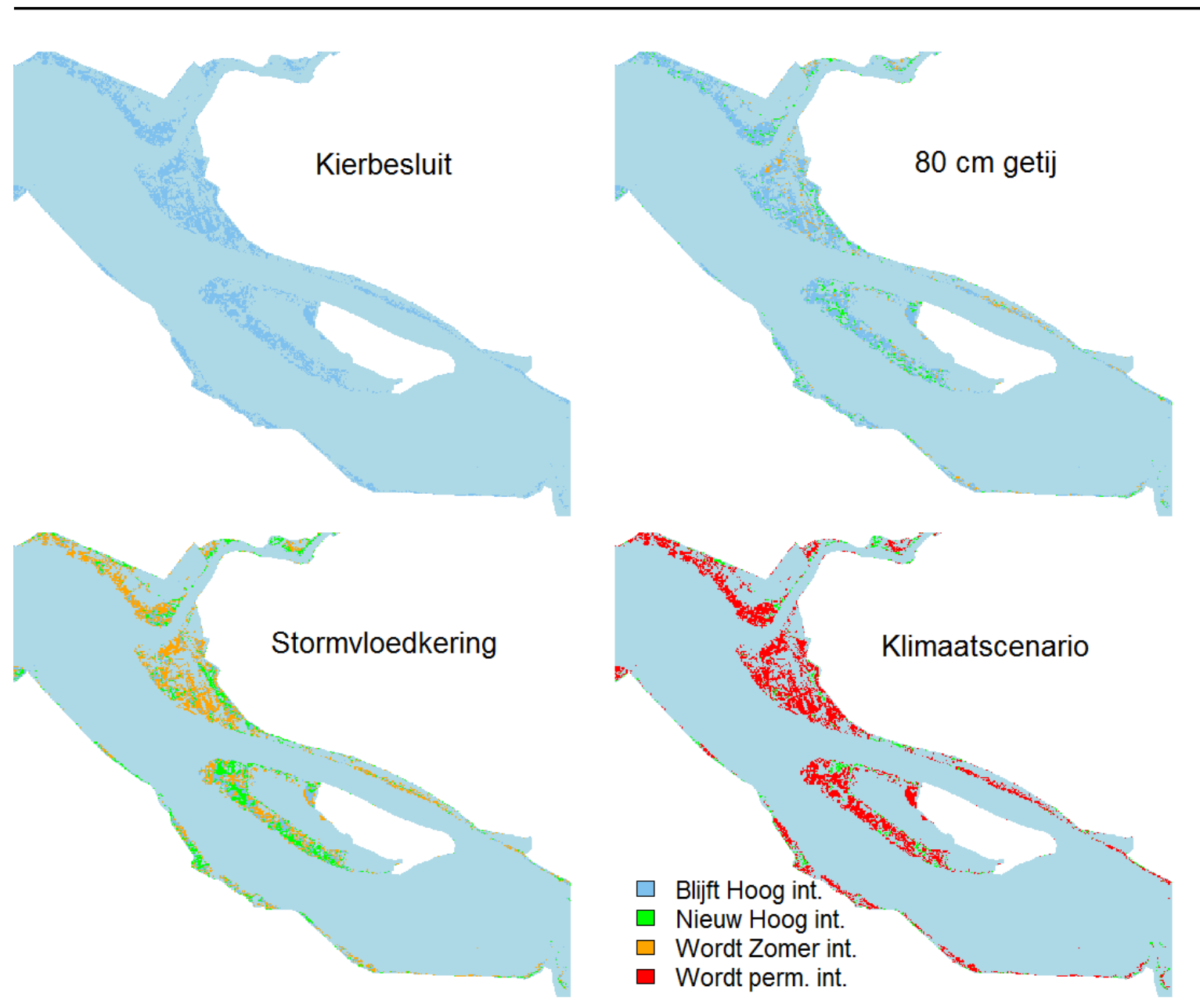

Figuur 77 Uitvergroting van Figuur 76 voor het oostelijk deel van het Haringvliet. Verschilkaarten van het ecotoop Hoog intergetijdengebied (variant - Huidig beheer). In donkerder blauw is het gebied aangegeven wat Hoog intergetijdengebied blijft. De groene gebieden zijn de nieuwe gebieden waar Hoog intergetijdengebied ontstaat (was terrestrisch in de variant Huidig beheer). De oranje gebieden zijn de gebieden waar het ecotoop Hoog intergetijdengebied plaatsmaakt voor Zomer intergetijdengebied. De rode gebieden zijn de gebieden waar het ecotoop Hoog intergetijdengebied plaatsmaakt voor permanent intergetijdengebied. 
Wageningen Marine Research

T: $+31(0) 317480900$

E: marine-research@wur.nl

www.wur.nl/marine-research

Visitors address

- Ankerpark 271781 AG Den Helder

- Korringaweg 7, 4401 NT Yerseke

- Haringkade 1, 1976 CP IJmuiden
Wageningen Marine Research is the Netherlands research institute established to provide the scientific support that is essential for developing policies and innovation in respect of the marine environment, fishery activities, aquaculture and the maritime sector.

Wageningen University \& Research is specialised in the domain of healthy food and living environment.

\section{The Wageningen Marine Research vision:}

'To explore the potential of marine nature to improve the quality of life.'

\section{The Wageningen Marine Research mission}

- To conduct research with the aim of acquiring knowledge and offering advice on the sustainable management and use of marine and coastal areas.

- Wageningen Marine Research is an independent, leading scientific research institute.

Wageningen Marine Research is part of the international knowledge organisation Wageningen UR (University \& Research centre). Within Wageningen UR, nine specialised research institutes of Stichting Wageningen Research (a Foundation) have joined forces with Wageningen University to help answer the most important questions in the domain of healthy food and living environment. 